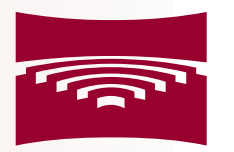

\title{
Edìte Vārtinga
}

\section{Labā priekškambara audu morfoloǵisks raksturojums pacientiem ar koronāro sirds slimību un deǵeneratīvu aortālā vārstuḷa stenozi}

Promocijas darbs zinātniskā doktora grāda "zinātnes doktors (Ph.D.)" iegūšanai Nozare - medicinas bāzes zinātnes, tai skaitā farmācija Apakšnozare - histoloǵija un citoloǵija 


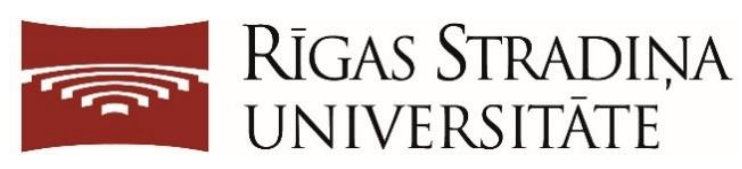

Edīte Vārtiṇa

ORCID 0000-0002-9639-2883

\title{
Labā priekškambara audu morfoloǵisks raksturojums pacientiem ar koronāro sirds slimību un deǵeneratīvu aortālā vārstuḷa stenozi
}

\author{
Promocijas darbs zinātniskā doktora grāda \\ "zinātnes doktors (Ph.D.)" iegūšanai \\ Nozare - medicīnas bāzes zinātnes, tai skaitā farmācija \\ Apakšnozare - histologija un citologija
}

Promocijas darba vadītāji:

Dr. med., Dr. habil. med. profesore Māra Pilmane,

Rīgas Stradiņa universitāte, Anatomijas un antropologijas institūts, Latvija

Dr. med., Dr. habil. med. profesors Romans Lācis,

Rīgas Stradiṇa universitāte, Ķirurğijas katedra, Latvija

Rīga, 2021 


\section{Anotācija}

Vienas no biežāk sastopamajām iegūtajām sirdskaitēm ir koronārā sirds slimība (KSS) un sirds vārstuḷu kaites, no kurām biežākā izolētā sirdskaite pieaugušajiem ir deǵeneratīva aortālā vārstuḷa (AoV) stenoze. Gan KSS, gan deǵeneratīvai AoV stenozei ir kopīgi attīstības riska faktori - vecums, paaugstināts zema blīvuma holesterīna līmenis asinīs, cukura diabēts, smēḳēšana, paaugstināts asinsspiediens, iekaisums un metaboliskais sindroms. Ne tikai riska faktori, bet arī patofizioloǵiskās izmaiṇas, it īpaši deǵeneratīva aortālā vārstuḷa stenozes sākuma stadijās, ir līdzīgas aterosklerozei - endotēlija bojājums, lipīdu izgulsnēšanās, fokāla skleroze, iekaisuma šūnu infiltrācija, citokīnu atbrīvošanās un kalcifikācija. Tomēr ne vienmēr šīs slimības tiek novērotas abas reizē. Tas apstiprina katrai slimībai specifiskus riska un patoǵenēzes faktorus. Lai gan šīs sirds saslimšanas ir zināmas jau sen un tiek intensīvi pētītas, joprojām trūkst ticamu marķieru, kas varētu palīdzēt paredzēt slimības progresēšanu, turpmāko operācijas nepieciešamību un mirstību. Izmaiņas audos šo slimību gadījumos ir komplicētas un ietver šūnu nāvi, sirds inervācijas, audu išēmijas rādītāju, metabolismu un homeostāzi regulējošo faktoru, iekaisuma un pretiekaisuma marķieru un citas pārmaiņas, kas joprojām nav līdz galam izzinātas.

Darba mērḳis bija noteikt apoptozes, homeostāzi regulējošo faktoru, inervācijas, išēmijas un iekaisuma marḳieru izplatību labā priekškambara audos koronāras sirds slimības un deǵeneratīva aortālā vārstuḷa atveres stenozes gadījumos.

Kopā pētījumā iekḷauti 36 pacienti ar iegūtām sirdskaitēm - 24 pacienti ar koronāru sirds slimību un 12 pacienti ar deǵeneratīvu aortālā vārstuḷa stenozi. Pētījumā izmantotais audu materiāls - labā priekškambara austiņas fragmenti - iegūts plānveida sirds operāciju laikā. Kāa pētījuma kontroles grupa izmantoti labā priekškambara audu paraugi no 5 pacientiem ar iedzimtām sirdskaitēm, kas operēti agrīnā vecumā. Audus krāsoja ar hematoksilīnu un eozīnu rutīnas gaismas mikroskopijai, apstrādāja pēc biotīna - streptovidīna metodes imūnhistoḳīmiskai audu marķieru noteikšanai un pēc TUNEL metodes apoptotisku šūnu noteikšanai. Ar imūnhistoḳīmijas metodi labā priekškambara audos noteikti šādi marķieri: ātriju nātrijurētiskais peptīds (ANUP), PGP 9.5 saturoša inervācija, asinsvadu endotēlija augšanas faktors (VEGF), hromogranīns A (ChgA), endotelīns 1 (ET-1), interleikīns $1 \alpha$ (Il-1 $\alpha)$, interleikīns 10 (Il-10), $\beta$ defensīni 2, 3 un 4 (attiecīgi $\beta$ D2, $\beta$ D3 un $\beta$ D4).

Labā priekškambara audus gan KSS, gan deǵeneratīvas AoV stenozes gadījumā raksturo nespecifiskas degீeneratīvas morfologiskas pārmaiņas - izteikta vakuolizācija, kā arī kardiomiocītu un to kodolu formas un izmēra maiṇa. Turklāt šiem pacientiem raksturīgs arī liels apoptotisko kardiomiocītu īpatsvars. Kaut gan AoV stenozes pacientiem nebija nozīmīgu 
bojājumu koronārajās artērijās, atsevišķiem pacientiem abās pētītajās grupās novērojām saistaudu ieaugšanu un asinsvadu sklerozi.

KSS un deǵeneratīvas AoV stenozes gadījumā notiek labā priekškambara endokarda endotēlija šūnu aktivācija, kam raksturīga formas maiṇa no plakanas uz kubisku un bagātīga ChgA, ET-1, Il-1 $\alpha$, Il-10, $\beta$ D2 un $\beta$ D3 izdale.

Pacientiem ar KSS un AoV stenozi labā priekškambara audos bija vairāk ANUP pozitīvu kardiomiocītu, visu veidu Il-10 pozitīvu šūnu un $\beta \mathrm{D} 2$ un $\beta \mathrm{D} 3$ pozitīvu endokarda endotēlija šūnu, bet mazāk ChgA pozitīvu šūnu nekā pacientiem ar iedzimtām sirdskaitēm. Tātad abu pētīto iegūto sirdskaišu gadījumā labā priekškambara audos prevalē pretiekaisuma reakcija, bet palielināta neiroendokrīnās sistēmas aktivitāte vairāk raksturīga pacientiem ar iedzimtām sirdskaitēm agrīnā vecumā.

Lai arī novērojām atsevišķas tendences, piemēram, KSS grupā labā priekškambara audos bija nedaudz vairāk VEGF, ET-1, Il-1 $\alpha$ pozitīvu endokarda endotēlija šūnu, Il-10 pozitīvu kardiomiocītu, saistaudu un endotēlija šūnu, bet AoV stenozes grupā - ChgA pozitīvu endokarda endotēlija šūnu, tomēr statistisku nozīmīgumu šīs atšķirības nesasniedza.

Vispārsteidzošākais atklājums mūsu pētījumā bija bagātīgā antimikrobo peptīdu atradne labā priekškambara audos gan pacientiem ar KSS, gan pacientiem ar deǵeneratīvu AoV stenozi, gan pacientiem ar iedzimtām sirdskaitēm jeb kontroles grupā.

Atslēgvārdi: labais priekškambaris, ātriju nātrijurētiskais peptīds, PGP 9.5 saturoša inervācija, asinsvadu endotēlija augšanas faktors, hromogranīns A, endotelīns 1, interleikīns $1 \alpha$, interleikīns $10, \beta$ defensīni. 


\section{Abstract \\ Right Atrial Morphology in Coronary Heart Disease and Degenerative Aortic Valve Stenosis}

One of the main forms of cardiovascular diseases is coronary heart disease (CHD) but degenerative aortic valve (AoV) stenosis is the most frequent native valve disease. Both CHD and degenerative AoV stenosis have common risk factors such as age, high blood cholesterol, diabetes, smoking, high blood pressure, inflammation, and metabolic syndrome. Not only risk factors, but also pathophysiological changes, especially in the early stages of degenerative aortic valve stenosis, are similar to atherosclerosis - endothelial damage, lipid deposition, focal sclerosis, inflammatory cell infiltration, cytokine release and calcification. However, these conditions are not always observed at the same time. This confirms the existence of risk and pathogenesis factors specific to each disease.

Although these heart diseases have been known for a long time and are intensively studied, there is still a lack of reliable markers that could help predict disease progression, the need for further surgery and mortality, therefore the pathophysiological processes involved in disease pathogenesis should be re-evaluated. Tissue changes in these diseases are complex and include cell death, cardiac innervation, tissue ischemia, regulators of metabolism and homeostasis, markers of inflammation and anti-inflammation, and other changes that are still not fully understood.

Aim of the study: to determine the prevalence of markers of apoptosis, homeostasis regulating factors, innervation, ischemia and inflammation in right atrial tissue in cases of coronary heart disease and degenerative aortic valve stenosis.

The tissue material used in the study - fragments of the right atrial appendage collected during elective open heart surgeries. A total of 36 patients with acquired heart diseases were included in the study - 24 patients with coronary heart disease and 12 patients with degenerative aortic valve stenosis. Samples of right atrial tissue from 5 patients with congenital heart disease operated at an early age were used as the study control group. Tissues were stained with hematoxylin and eosin for routine light microscopy, treated with the biotin-streptovidine method for immunohistochemical detection of tissue markers and by the TUNEL method for the detection of apoptotic cells. The following markers were identified in right atrial tissue by immunohistochemistry: atrial natriuretic peptide (ANUP), PGP 9.5- containing innervation, vascular endothelial growth factor (VEGF), chromogranin A (ChgA), endothelin 1 (ET-1), interleukin $1 \alpha$ (Il-1 $\alpha$ ), interleukin 10 (II-10), $\beta$ defensins 2, 3 and 4 ( $\beta$ D2, $\beta$ D3 and $\beta$ D4, respectively). 
Right atrial tissue in both CHD and degenerative AoV stenosis is characterized by nonspecific degenerative morphological changes - pronounced vacuolization as well as changes in the shape and size of cardiomyocytes and their nuclei. In addition, these patients have a high proportion of apoptotic cardiomyocytes. Although there were no significant lesions in the coronary arteries in patients with AoV stenosis, connective tissue ingrowth and vascular sclerosis were observed in some patients in both groups.

In the case of $\mathrm{CHD}$ and degenerative AoV stenosis, activation of the right atrial endocardial endothelial cells occurs, characterized by a change of shape from flat to cubic and rich release of ChgA, ET-1, Il-1 $\alpha, \mathrm{Il}-10, \beta \mathrm{D} 2$ and $\beta \mathrm{D} 3$.

Patients with CHD and AoV stenosis in the right atrial tissue had statistically significant higher numbers of ANUP-positive cardiomyocytes, all types of IL-10 positive cells and $\beta \mathrm{D} 2$ and $\beta \mathrm{D} 3$-positive endocardial endothelial cells, but fewer ChgA-positive cells than controls or patients with congenital heart disease. Thus, in both cases of acquired heart disease, an antiinflammatory response prevails in the right atrial tissue, but increased activity of the neuroendocrine system is more common in patients with congenital heart disease at an early age.

Although some tendencies were observed, for example, in the CHD group, there were slightly more VEGF, ET-1, Il-1 $\alpha$ positive endocardial endothelial cells, Il-10 positive cardiomyocytes, connective tissue and endothelial cells, but in AoV stenosis group, there were slightly more ChgA-positive endocardial endothelial cells, however, these differences did not reach statistical significance.

The most striking finding in our study was the rich expression of antimicrobial peptides, such as human $\beta$ defensins 2 and 3, in the right atrial tissues in patients with CHD, degenerative AoV stenosis and congenital heart disease.

Keywords: right atrium, atrial natriuretic peptide, PGP 9.5-containing innervation, vascular endothelial growth factor, chromogranin A (ChgA), endothelin 1 (ET-1), interleukin $1 \alpha$ (Il-1 $\alpha$ ), interleukin 10 (II-10), $\beta$ defensins 2,3 and 4 ( $\beta$ D2, $\beta$ D3 and $\beta$ D4, respectively). 


\section{Saturs}

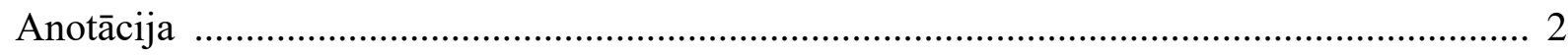

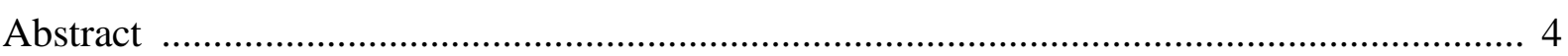

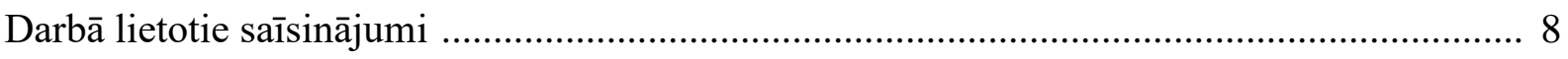

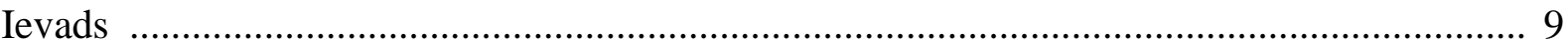

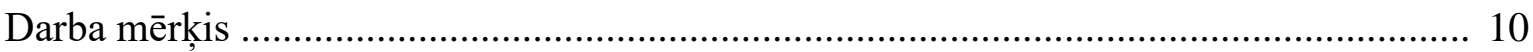

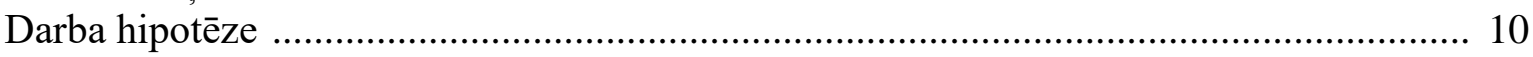

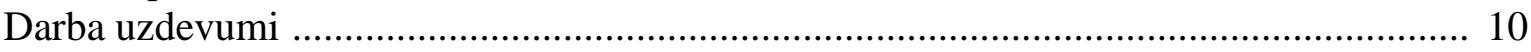

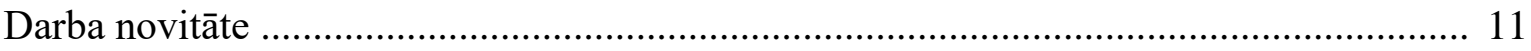

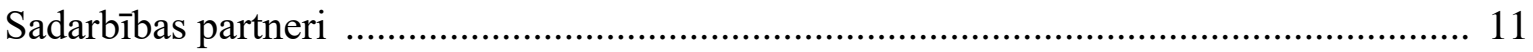

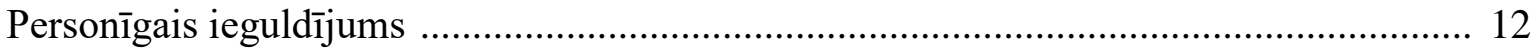

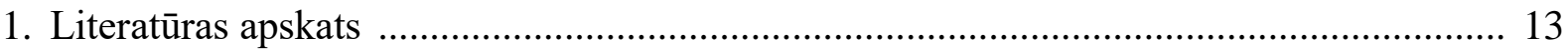

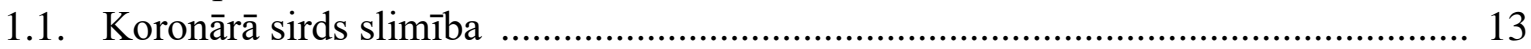

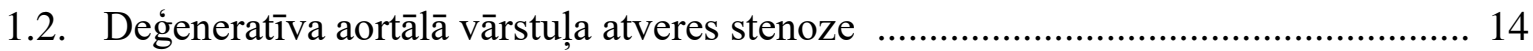

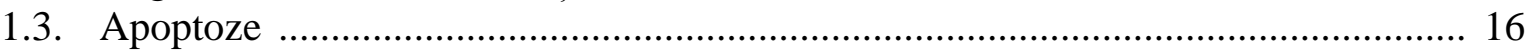

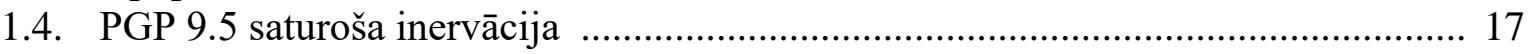

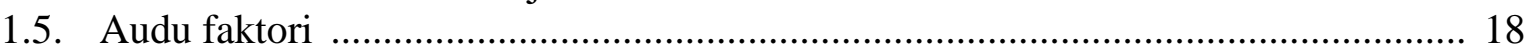

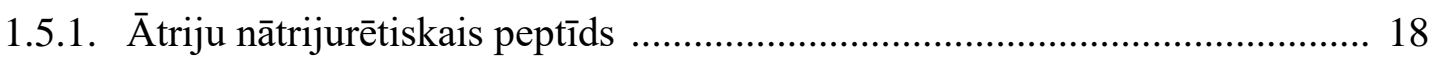

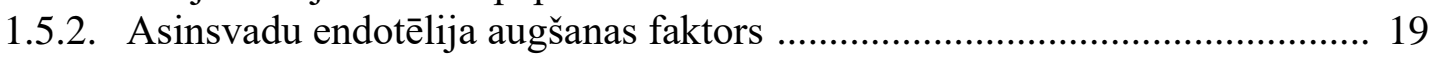

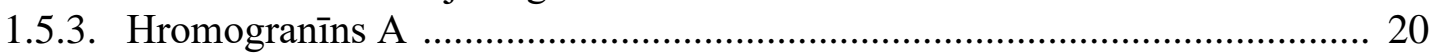

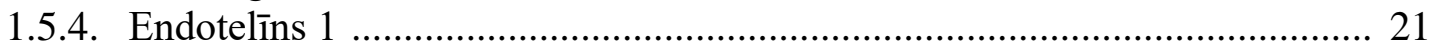

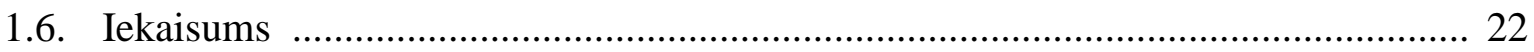

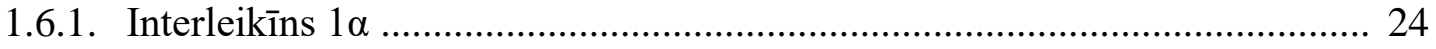

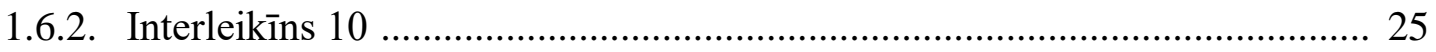

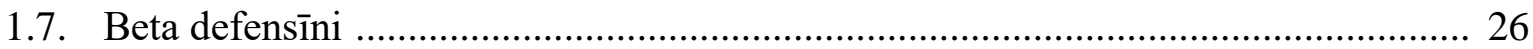

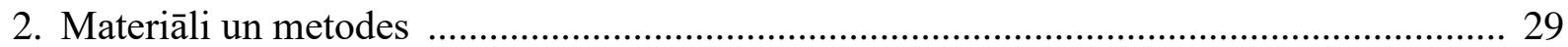

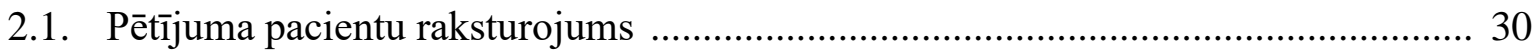

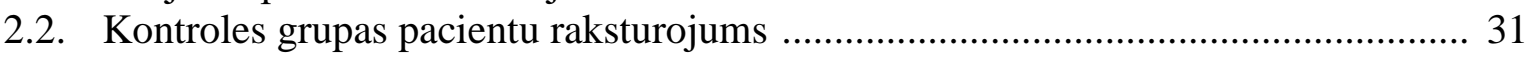

2.3. Audu griezumu iegūšana un sagatavošana krāsošanai ...................................... 32

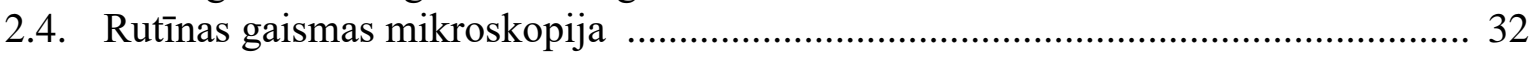

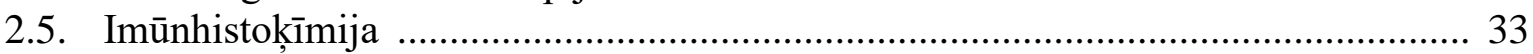

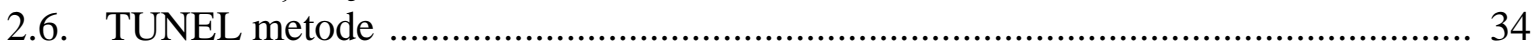

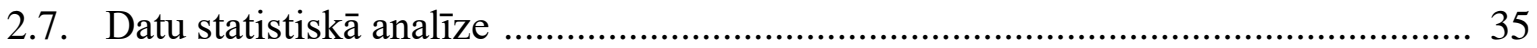

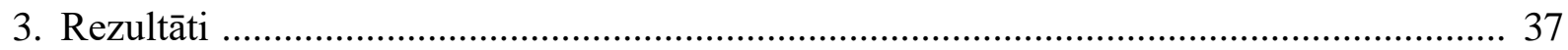

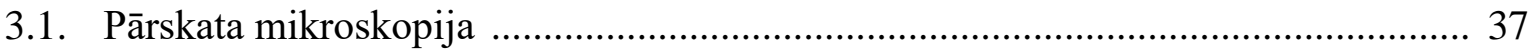

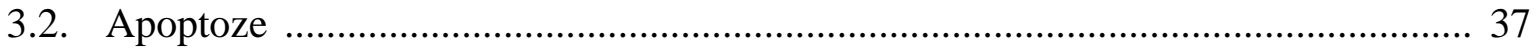

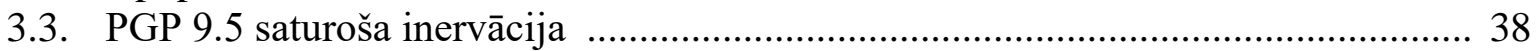

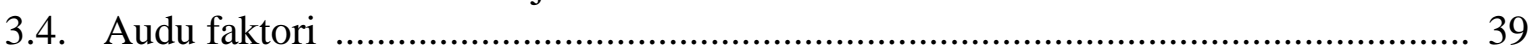

3.4.1. Ātriju nātrijurētiskais peptīds (ANUP) ................................................ 39

3.4.2. Asinsvadu endotēlija augšanas faktors (VEGF) ....................................... 41

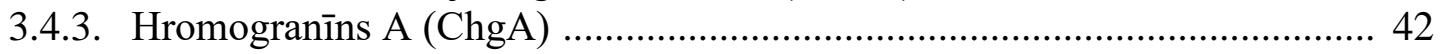

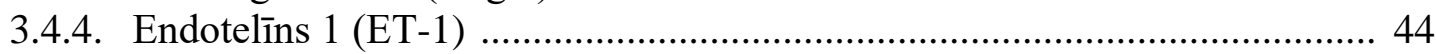

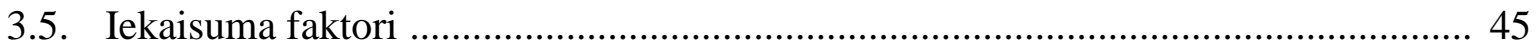

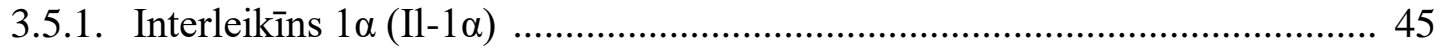

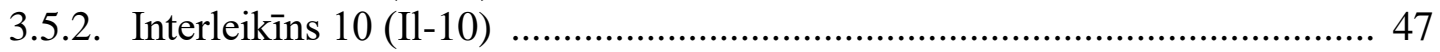

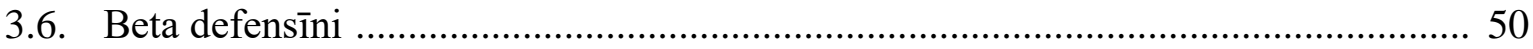

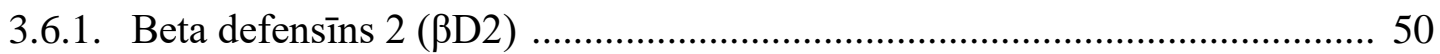




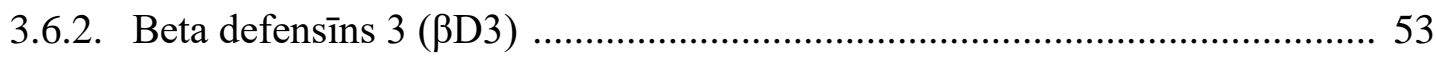

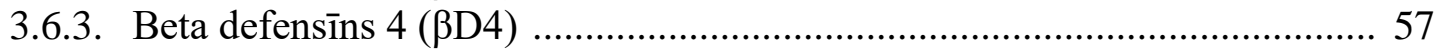

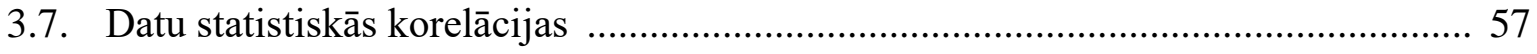

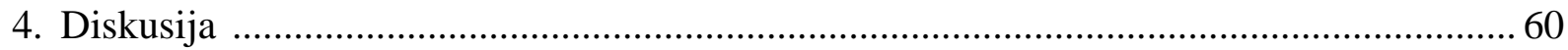

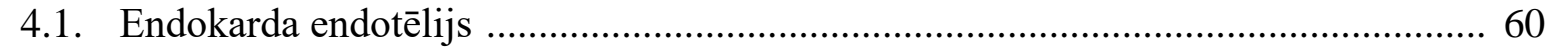

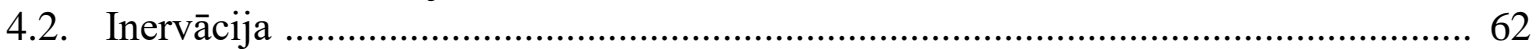

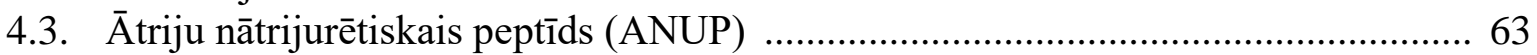

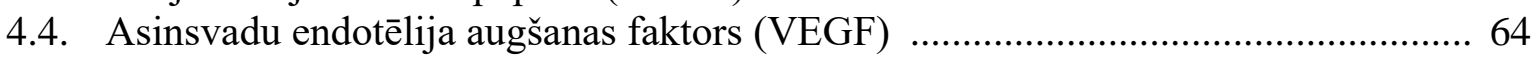

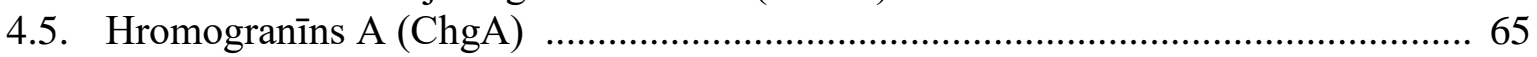

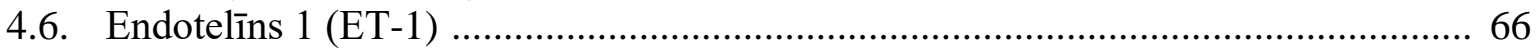

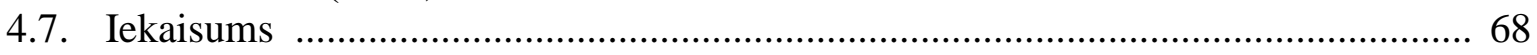

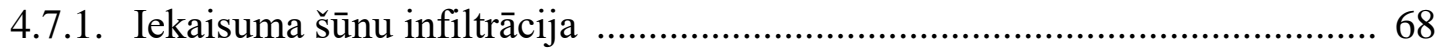

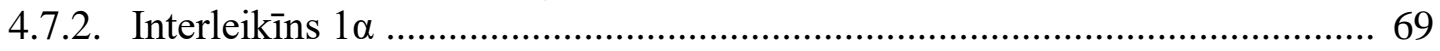

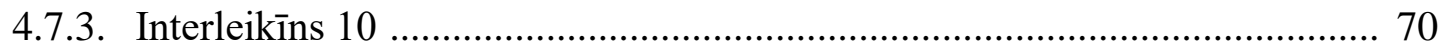

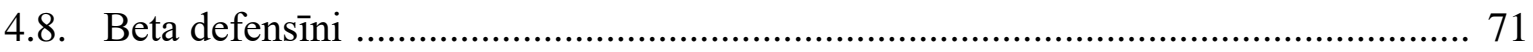

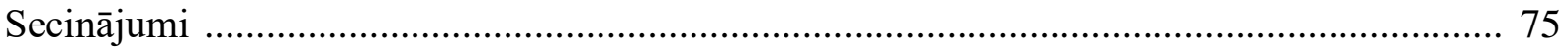

Publikācijas un ziṇojumi par promocijas darba tēmu ........................................................... 77

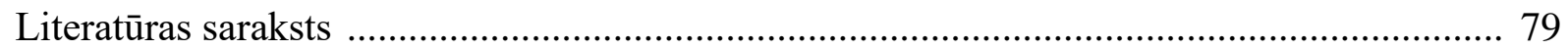

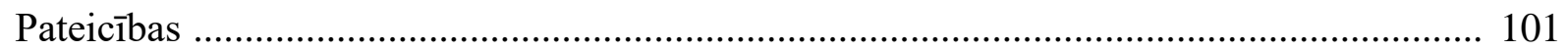

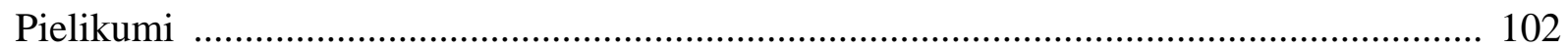

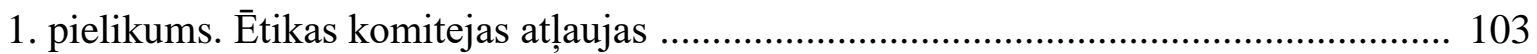

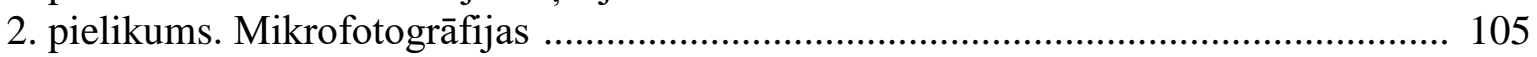




\section{Darbā lietotie saīsinājumi}

\section{Saīsinājums}

ABLH

ANUP

AoV

BNP

ChgA

DNS

ET-1

Il-10

Il- $1 \alpha$

KG

KKEF

KSS

LKSS

mRNS

PGP 9.5

RAA

TG

TNF $\alpha$

VEGF

ZBLH

$\beta \mathrm{D} 1$

$\beta \mathrm{D} 2$

$\beta \mathrm{D} 3$

$\beta \mathrm{D} 4$

\section{Nosaukums latviešu valodā}

Augsta blīvuma holesterīns

Ātriju nātrijurētiskais peptīds

Aortālais vārstulis

Smadzeņu nātrijurētiskais peptīds

Hromogranīns A

Dezoksiribonukleīnskābe

Endotelīns 1

Interleikīns 10

Interleikīns $1 \alpha$

Koronarogrāfija

Kreisā kambara izsviedes frakcija

Koronāra sirds slimība

Labā kambara sistoliskais spiediens

Matrices ribonuklēinskābes

Proteīna gēna produkts 9.5

Labā priekškambara laukums

Triglicerīdi

Tumora nekrozes faktors $\alpha$

Asinsvadu endotēlija augšanas faktors

Zema blīvuma holesterīns

Beta defensīns 1

Beta defensīns 2

Beta defensīns 3

Beta defensīns 4

\section{Nosaukums angḷu valodā}

High-density lipoprotein

Atrial natriuretic peptide

Aortic valve

Brain natriuretic peptide

Chromogranin A

Deoxyribonucleic acid

Endothelin 1

Interleukin 10

Interleukin $1 \alpha$

Coronary angiogram

Left ventricular ejection fraction

Coronary heart disease

Right ventricular systolic pressure

Messenger ribonucleic acid

Protein gene producēt 9.5

Right atrial area

Triglycerides

Tumor necrosis factor $\alpha$

Vascular endothelial growth factor

Low-density lipoprotein

Beta defensin 1

Beta defensin 2

Beta defensin 3

Beta defensin 4 


\section{Ievads}

Kaut arī mirstība no sirds un asinsvadu slimībām pēdējos gados lielākajā daḷā Eiropas valstu mazinās, tā joprojām ir viena no galvenajām sabiedrības veselības problēmām visā pasaulē, katru gadu izraisot 3,9 miljonu Eiropas iedzīvotāju nāvi (Wilkins et al., 2017). Pēc Pasaules Veselības organizācijas datiem, 2016. gadā visā pasaulē no sirds un asinsvadu slimībām mira 17,9 miljoni cilvēku, kas ir aptuveni trešā daḷa no visiem nāves gadījumiem (World Health Organization, 2017). Arī Latvijā gan biežākais nāves iemesls, gan biežākais priekšlaicīgas mirstības iemesls joprojām ir asinsrites sistēmas slimības (Skrule, 2018). Turklāt sirds un asinsvadu sistēmas slimības ir nāves cēlonis, kura īpatsvars Latvijas iedzīvotāju nāves cēloṇu struktūrā simt gadu griezumā ir pieaudzis visbūtiskāk (Štāle, Skrule and Rožkalne, 2018).

Vienas no biežāk sastopamajām iegūtajām sirdskaitēm ir koronārā sirds slimība (KSS) un sirds vārstuḷu kaites, no kurām biežākā izolētā sirdskaite pieaugušajiem ir deǵeneratīva aortālā vārstuḷa (AoV) stenoze (Baumgartner et al., 2017). Gan KSS, gan deǵeneratīvai AoV stenozei ir kopīgi attīstības riska faktori - vecums, paaugstināts zema blīvuma holesterīna līmenis asinīs, cukura diabēts, smēḳēšana, paaugstināts asinsspiediens, iekaisums un metaboliskais sindroms (Stewart et al., 1997). Ne tikai riska faktori, bet arī patofiziologiskās izmaiņas, it īpaši deǵeneratīvas aortālā vārstuḷa stenozes sākuma stadijās, ir līdzīgas aterosklerozei - endotēlija bojājums, lipīdu izgulsnēšanās, fokāla skleroze, iekaisuma šūnu infiltrācija, citokīnu atbrīvošanās un kalcifikācija (Milin et al., 2014). Tomēr ne vienmēr šīs slimības tiek novērotas abas reizē - KSS konstatēta $60 \%$ pacientu, kam veikta ķirurgíiska aortālā vārstuḷa protezēšana, un $65 \%$ pacientu, kam veikta transkatetra AoV protēzes implantācija (Sabbagh and Nishimura, 2017). Tas apstiprina katrai slimībai specifiskus riska un patoǵenēzes faktorus (Henein et al., 2015). Tā kā abas šīs slimības progresē līdz ar vecumu, tad, sabiedrībai novecojot, to izplatîba pieaug.

Lai gan šīs sirds saslimšanas ir zināmas jau sen un tiek intensīvi pētītas, joprojām trūkst ticamu marķieru, kas varētu palīdzēt paredzēt slimības progresēšanu, turpmāko operācijas nepieciešamību un mirstību, tādēḷ būtu jāpārvērtē slimību patoǵenēzē iesaistītie patofizioloǵiskie procesi. Izmaiņas audos šo slimību gadījumos ir komplicētas un ietver šūnu nāvi, sirds inervācijas, audu išēmijas rādītāju, metabolismu un homeostāzi regulējošo faktoru, iekaisuma un pretiekaisuma marķieru un citas pārmaiņas, kas joprojām nav piln̄̄bā izzinātas. Būtisks uzdevums zinātniekiem ir izdalīt un noteikt tos biomarķierus, kuriem būtu nozīme agrīnā diagnostikā, terapijas izvēlē un kuri ḷautu prognozēt slimības gaitu un iznākumu. 


\section{Darba mērḳis}

Noteikt apoptozes, homeostāzi regulējošo faktoru, inervācijas, išēmijas un iekaisuma marḳieru izplatību labā priekškambara audos koronāras sirds slimības un deǵeneratīva aortālā vārstuḷa atveres stenozes gadījumos.

\section{Darba hipotēze}

Koronāras sirds slimības un aortālā vārstuḷa deǵeneratīvas stenozes gadījumos ir mainīta un atšķirīga homeostāzi regulējošo faktoru, išēmijas, inervācijas un iekaisuma marḳieru ekspresija labā priekškambara audos.

\section{Darba uzdevumi}

1. Izvērtēt labā priekškambara audu struktūru rutīnā mikroskopijā pēc krāsošanas ar hematoksilīnu un eozīnu pacientiem ar koronāru sirds slimību, deǵeneratīvu aortālā vārstuḷa stenozi un kontroles audos, kā arī statistiski analizēt iegūtos datus.

2. Noteikt apoptozes indeksu un apoptotisko šūnu skaitu labā priekškambara audos koronāras sirds slimības, aortālā vārstuḷa stenozes gadījumos un kontroles audos, kā arī statistiski analizēt iegūtos datus.

3. Noteikt homeostāzi regulējošā faktora ātriju nātrijurētiskā peptīda ekspresiju labā priekškambara audos koronāras sirds slimības, aortālā vārstuḷa stenozes gadījumos un kontroles audos, kā arī statistiski analizēt iegūtos datus.

4. Noteikt išēmijas marḳiera asinsvadu endotēlija augšanas faktora ekspresiju labā priekškambara audos koronāras sirds slimības, aortālā vārstuḷa stenozes gadījumos un kontroles audos, kā arī statistiski analizēt iegūtos datus.

5. Noteikt vazokonstriktora endotelīna 1 ekspresiju labā priekškambara audos koronāras sirds slimības, aortālā vārstuḷa stenozes gadījumos un kontroles audos, kā arī statistiski analizēt iegūtos datus.

6. Izvērtēt inervācijas izmaiņas labā priekškambara audos pacientiem ar koronāru sirds slimību, deǵeneratīvu aortālā vārstuḷa stenozi un kontroles audos, kā arī statistiski analizēt iegūtos datus.

7. Izvērtēt neiroendokrīnās sistēmas iesaisti, nosakot hromogranīnu A labā priekškambara audos pacientiem ar koronāru sirds slimību, deǵeneratīvu aortālā vārstuḷa stenozi un kontroles audos, kā arī statistiski analizēt iegūtos datus. 
8. Izvērtēt iekaisuma un pretiekaisuma procesus, nosakot interleikīnu $1 \alpha$ un interleikīnu 10 labā priekškambara audos koronāras sirds slimības, aortālā vārstuḷa stenozes gadījumos un kontroles audos, kā arī statistiski analizēt iegūtos datus.

9. Noteikt antibakteriālo peptīdu (beta defensīnu 2, 3 un 4) ekspresiju labā priekškambara audos koronāras sirds slimības, aortālā vārstuḷa stenozes gadījumos un kontroles audos, kā arī statistiski analizēt iegūtos datus.

\section{Darba novitāte}

Šajā pētījumā ar imūnhistoḳīmijas metodi noteicām dažādus audu, inervācijas, iekaisuma, pretiekaisuma faktorus un antimikrobos peptīdus labā priekškambara audos pacientiem ar KSS un deǵeneratīvu AoV stenozi, kā kontroles grupu izmantojot labā priekškambara audu paraugus no pacientiem ar iedzimtām sirdskaitēm, kas operēti agrīnā vecumā. Pozitīvo struktūru daudzumu analizējām 4 dažādās labā priekškambara audu grupās kardiomiocītos, saistaudu šūnās, asinsvadu un endokarda endotēlija šūnās. Kopumā noteicām 11 dažādus marķierus: apoptozi, ANUP, VEGF, PGP 9.5 saturošu inervāciju, ChgA, ET-1, Il-1 $\alpha$, Il-10, $\beta$ D2, $\beta$ D3 un $\beta$ D4. Līdz šim šādā kombinācijā tie vēl nav pētīti, un, tā kā daži no šiem marḳieriem jau ir sen zināmi un plaši pētīti, saliekot tos kopā ar mazāk zināmiem, gūstam plašāku ieskatu par morfologiiskajām norisēm labā priekškambara audos pacientiem ar KSS un deǵeneratīvu AoV stenozi, kas uzskatāma par darba novitāti.

\section{Sadarbības partneri}

Pētījuma materiāls - labā priekškambara audu fragmenti no pacientiem ar KSS un AoV stenozi - iegūts Paula Stradiṇa Klīniskās universitātes slimnīcas Sirds ķirurǵijas centrā. Kontroles materiāls - labā priekškambara audu fragmenti no pacientiem ar iedzimtām sirdskaitēm, kas operēti agrīnā vecumā, - iegūts no Rīgas Stradiṇa universitātes Anatomijas un antropologiijas institūta vēsturiskās kolekcijas.

Audu sagatavošana un krāsošana pēc histologijijas, imūnhistoķīmijas un TUNEL metodes veikta Rīgas Stradiņa universitātes Anatomijas un antropologijas institūta Morfologijas laboratorijā. Paraugu analīze un mikrofotogrāfiju uzṇemšana veikta Rīgas Stradiṇa universitātes Anatomijas un antropolog̣ijas institūta Morfolog̣ijas katedrā. 


\section{Personīgais ieguldījums}

Darba autore ir ieguvusi pētîjuma audu paraugus un analizējusi katru audu paraugu gaismas mikroskopā, kā arī veikusi iegūto datu statistisko analīzi. Kopā analizēti 492 audu paraugi. Autore ir sarakstījusi šo darbu un ir visu darbā iekḷauto mikrofotogrāfiju autore. 


\section{Literatūras apskats}

\subsection{Koronārā sirds slimība}

Koronārā sirds slimība (KSS) ir patologisks process, ko raksturo obstruktīvas vai neobstruktīvas aterosklerotiskas plātnes veidošanās koronārajās artērijās, kas rada samazinātu miokarda perfūziju (Knuuti et al., 2019). Pēc Pasaules Veselības organizācijas datiem, KSS joprojām ir viens no galvenajiem nāves iemesliem valstīs ar vidējiem un augstiem ienākumiem (World Health Organization, 2018).

Sirds apasiņošanu nodrošina koronārās jeb vainagartērijas - labā vainagartērija un 2 kreisās vainagartērijas, kas parasti sākas ar kopēju stumbru un tālāk sadalās kreisajā priekšējā lejupejošā artērijā un apliecošajā artērijā (Rūmanss, Kažoka and Pilmane, 2019a).

80-90 \% pacientu ar pierādītu KSS ir vismaz viens no vispārpieṇemtajiem KSS riska faktoriem - smēḳēšana, cukura diabēts, hiperlipidēmija vai hipertensija (Khot et al., 2003). G̣enētiska predispozīcija un kardiovaskulārie riska faktori izraisa patoloǵiskus apstākḷus, kuros tiek producēti tādi proinflammatori citokīni kā interleikīns 1 un tumora nekrozes faktors $\alpha$, kas savukārt izraisa iekaisuma šūnu migrāciju artēriju sieniņā (Willerson and Ridker, 2004). Monocīti diferencējas par makrofāgiem, absorbē ar holesterīnu bagātus zema blīvuma lipoproteīnus un kḷūst par tā sauktajām putu šūnām, kas izgulsnējas artērijas sieniṇā (Fioranelli et al., 2018). Aterosklerotiskas plātnes ir asimetriski, lokāli artērijas iekšējā slāņa intīmas sabiezējumi, kas satur šūnas, galvenokārt makrofāgus un T limfocītus, saistaudu elementus un lipīdus (Hansson, 2005). Aterosklerotisko plātni pārklāj fibrozs slānis, kas satur intersticiālo kolagēnu, ko producē artēriju gludās muskulatūras šūnas un kas nodrošina plātnes stabilitāti (Libby, 2013). Plātnē esošie makrofāgi atbrīvo proteolītiskus fermentus metaloproteināzes, kas sadala kolagēnu, padarot plātnes virskārtu vājāku (Willerson and Ridker, 2004). Šādas plātnes tiek sauktas par nestabilām pangām, jo plīstot inducē trombozi. Trombs savukārt noslēdz atlikušo artērijas lūmenu, radot miokarda infarktu.

Nepietiekamas asins apgādes apstākḷıs miokardā notiek remodelācija, kas ietver kardiomiocītu zudumu, fibrozi, kardiomiocītu hipertrofiju un jaunu asinsvadu veidošanos (Schirone et al., 2017). KSS gadījumā jaunu asinsvadu veidošanās miokardā notiek, izmantojot divus ceḷus - angioǵenēzi un arterioǵenēzi. Hipoksija izraisa pastiprinātu VEGF produkciju, kas stimulē angioǵenēzi jeb jaunu kapilāru veidošanos no jau esošajiem (Buschmann and Schaper, 1999). Šì procesa rezultātā miokardā veidojas blīvs kapilāru tīklojums, ko novēro tieši išēmiskās zonās (Potz et al., 2017). Arterioǵenēzi jeb kolaterālu artēriju augšanu novēro hipoksijas neskartos audos, to galvenokārt izraisa izmainīta asins plūsma artēriju oklūzijas dēl 
(Cai and Schaper, 2008). KSS pacientiem ar izteiktāku kolaterālu asins plūsmu ir zemāks nāves risks nekā pacientiem ar mazizteiktu kolaterālu plūsmu (Meier et al., 2007).

Išēmiskai miokarda remodelācijai raksturīga arī fibroze, kas ir divu veidu - aizvietojošā un reaktīvā. Aizvietojošā fibroze jeb rētas veidošanās notiek miokarda infarkta zonā - bojātie audi tiek aizstāti ar fibrozu rētu, ko rada fibroblasti un miofibroblasti (Shinde and Frangogiannis, 2014). Reaktīvās fibrozes veidošanās notiek infarkta neskartās miokarda zonās, ko izraisa mehānisks stress kopā ar hormonāliem un parakrīniem mediatoriem (Talman and Ruskoaho, 2016). Gan fibrozā rēta miokarda infarkta zonā, gan intersticiālā fibroze pārējā miokardā izraisa miokarda sistoliskās un diastoliskās funkcijas traucējumus, kā arī palielina aritmiju un pēkšņas nāves risku (Gulati et al., 2013; Weber et al., 2013).

\subsection{Deǵeneratīva aortālā vārstuḷa atveres stenoze}

Aortālā vārstuḷa (AoV) stenoze ir aortālā vārstuḷa atveres sašaurinājums, kas kreisā kambara izejas traktā rada asins plūsmas ātruma palielinājumu $>2 \mathrm{~m} / \mathrm{sekundē} \mathrm{(Sattar} \mathrm{et} \mathrm{al.,}$ 2019). Tā ir biežākā primārā vārstuḷu kaite, kuras gadījumā nepieciešama ķirurgíska korekcija Eiropā un Ziemel̦amerikā (Baumgartner et al., 2017). Kopējā populācijā aptuveni 12,4 \% vecāka gadagājuma cilvēku ir aortālā vārstuḷa stenoze, bet 3,4 \% ir smagas pakāpes aortālā vārstuḷa stenoze (Osnabrugge et al., 2013).

Aortālo vārstuli parasti veido 3 viras, kas nosauktas atbilstoši to atrašanās vietai pret koronārajām artērijām - kreisā koronārā, labā koronārā un nekoronārā vira (Rūmanss, Kažoka and Pilmane, 2019b). Virām ir pusmēness forma un trīs slāņu struktūra, kas nosaka to biomehāniskās īpašības (Chen and Simmons, 2011). Trīs slāṇus - fibrozo, spongiozo un ventrikulāro, kas pieaugušam veselam cilvēkam ir mazāk nekā $1 \mathrm{~mm}$ biezumā, - klāj vienkārtains vārstuḷa endotēlija slānis (Lindman et al., 2016). Viras iekšienē esošajos visos trijos slāņos ir vārstuḷa intersticiālās šūnas, no kurām lielākā daḷa ir fibroblasti, nedaudz miofibroblastu un gludās muskulatūras šūnu (Chen and Simmons, 2011).

Aortālā vārstuḷa viru deǵenerācija ir aktīvs, daudzšķautņains process, kas iekḷauj lipoproteīnu izgulsnēšanos, hronisku iekaisumu, vārstuḷa intersticiālo šūnu fenotipa maiņu, aktīvu viru kalcifikāciju un renīna-angiotenzīna sistēmas aktivizāciju (Freeman and Otto, 2005; O’Brien, 2006). Aortālā vārstuḷa viru deǵenerācija sākuma stadija jeb skleroze ir ḷoti līdzīga aterosklerozei, un to raksturo fokāls viru endotēlija bojājums, lipoproteīnu izgulsnēšanās, vēlāk kalcifikācija un sabiezēšana bez noz̄̄mīgas asins plūsmas obstrukcijas (Pawade, Newby and Dweck, 2015). Endotēlija bojājums ḷauj lipīdiem uzkrāties viras iekšienē. Līdzīgi aterosklerozei agrīnos aortālā vārstuḷa bojājumos atrod zema blīvuma lipoproteīnu, kas oksidējoties kḷūst 
citotoksiski un izraisa iekaisumu ar sekojošu mineralizāciju (Dweck, Boon and Newby, 2012). Slimībai progresējot, viras sabiezē, kḷūst mazkustīgas un sašaurina kreisā kambara izejas traktu, veidojot aortālā vārstuḷa stenozi.

Deǵeneratīva AoV stenoze ir ne tikai izmaiņas vārstuḷa virās, bet tā rada arī sekundāras izmaiņas, kas saistītas ar kreisā kambara izejas trakta sašaurināšanos. Pacienti ar deǵeneratīvu AoV stenozi ilgstoši ir asimptomātiski, to nosaka pakāpeniski progresējoša kompensatora kreisā kambara miokarda hipertrofija. Tās rezultātā palielinās kreisā kambara sistoliskā funkcija, kas palīdz nodrošināt adekvātu sistēmisko spiedienu caur stenotisku AoV atveri. Nekoriǵējot kaiti, kreisā kambara hipertrofija progresē, pievienojas miokarda fibroze un tas rezultējas ar diastolisku mazspēju (Hess et al., 1984; Chin et al., 2017). Turklāt AoV stenozes pacientiem ar kreisā kambara diastolisku mazspēju bieži novēro arī pulmonālu hipertensiju, kas savukārt saistāma ar sliktu prognozi gan pēc konvencionālas ķirurğiskas, gan pēc mazinvazīvas aortālā vārstuḷa protezēšanas (Luçon et al., 2014; Gumauskienė et al., 2018; Maeder et al., 2018).

Aortālā vārstuḷa stenozes biežums palielinās līdz ar vecumu, un vecums ir neatkarīgs riska faktors slimības sākumam (Owens et al., 2010). Citi riska faktori, kas saistāmi ar aortālā vārstuḷa stenozes incidenci vai progresu, ir: vīriešu dzimums, hipertensija, smēḳešsana, smagas pakāpes nieru mazspēja, cukura diabēts, palielināts ḳermeṇa masas indekss (O’Brien, 2006). Tomēr līdz šim nav atrasti riska faktori, kuru novēršana ticami palēninātu AoV stenozes progresēšanu. Arī par holesterīna līmeņa kā riska faktora AoV deǵenerācijas izraisīšanā un progresēšanā literatūrā ir pretrunīgi dati. Vairākos pētījumos novērota saistība starp holesterīna vai tā frakciju līmeni asinīs un aortālā vārstuḷa stenozes attīstību (Stewart et al., 1997; Owens et al., 2010). Citā pētījumā netika novērota holesterīna vai tā frakciju līmeņa saistība ar AoV stenozes progresu, tomēr pacientiem, kas terapijā saṇēma statīnu grupas preparātus, novēroja ievērojami lēnāku AoV stenozes progresu (Bellamy et al., 2002). Tomēr randomizētā, dubultaklā, placebo kontrolētā pētījumā pacientiem ar vieglu un mērenu deǵeneratīivu AoV stenozi netika konstatēts ieguvums no intensīvas lipīdu pazemināšanas (Rossebø et al., 2008).

Deǵeneratīvai aortālā vārstuḷa stenozei pēc simptomu parādīšanās ir raksturīga augsta morbiditāte un mirstība (Grimard, Safford and Burns, 2016). Pacientiem ar smagu AoV stenozi, kuriem netiek veikta aortālā vārstuḷa protezēšana, mirstība 1 gada laikā pēc simptomu parādīšanās ir 37 \% (Ben-Dor et al., 2010). Lai arī k̦irurğiskās un transkatetra vārstuḷa protezēšanas smagas aortālā vārstuḷa atveres stenozes gadījumos mūsdienās ir augsti attīstītas un drošas, joprojām nav pieejama efektīva profilaktiska medikamentozā terapija, kas palēninātu aortālā vārstuḷa stenozes progresu (Baumgartner et al., 2017). 


\subsection{Apoptoze}

Programmēta šūnu nāve jeb apoptoze ir autoregulēts, no kaspāzes atkarīgs un ǵenētiski kontrolēts šūnu nāves veids daudzšūnu organismos (Elmore, 2007; Galluzzi et al., 2015). Termins "apoptoze" pirmo reizi aprakstīts 1972. gadā (Kerr, Wyllie and Currie, 1972). Tas ir normāls fiziologisks process, kas nodrošina līdzsvara stāvokli audos, kuri nepārtraukti atjaunojas gan fiziologiiskos, gan patologiskos apstākḷlos. Apoptoze ir genētiski noteikta, un to raksturo hromatīna kondensācija, kodola saraušanās, apoptotisko ķermenīšu veidošanās un kontrolēta kodola DNS fragmentācija, kas ir galvenā apoptozes pazīme (Heatwole, 1999). Apoptoze tiek iniciēta un izpildīta pa diviem galvenajiem signālu pārvades ceḷiem - iekšējo un ārējo. Iekšējo jeb mitohondriju apoptozes ceḷu iniciē intracelulārs stress, piemēram, oksidatīvs stress, kalcija pārslodze, DNS bojājumi, bet ārējo apoptozes ceḷu iniciē ekstracelulāri stresa signāli, tai skaitā tumora nekrozes faktors $\alpha$, Fas ligandi, piesaistoties pie individuāliem receptoriem (Xia, Liu and Cheng, 2016). Kardiomiocītu apoptoze notiek gan pa iekšējo, gan pa ārējo apoptozes ceḷu (Whelan, Kaplinskiy and Kitsis, 2010).

Apoptozei ir būtiska nozīme gan sirds attīstībā, gan daudzu sirds slimību, piemēram, sirds išēmiskā slimība, kardiomiopātija, sirds mazspēja, patoǵenēzē (Haunstetter and Izumo, 1998). Lai arī apoptoze ir normāls fiziologisks process vesela pieauguša cilvēka sirdī, tomēr patologiiskos apstākḷlos tā izraisa kardiomiocītu zudumu, kas saistās ar dz̄ivībai bīstamiem sirds funkcijas traucējumiem (Chiong et al., 2011). Palielinātu kardiomiocītu apoptotisko indeksu novēro pacientiem ar dažādām kardiomiopātijām, piemēram, alkohola izraisītu kardiomiopātiju, dilatācijas kardiomiopātiju, aritmogēno kardiomiopātiju, išēmisku kardiomiopātiju (Olivetti et al., 1997; Glumac et al., 2016; Steiner and Lang, 2017; Austin et al., 2019).

Aterosklerotiskās plāksnēs visbiežāk novēro makrofāgu un asinsvadu gludās muskulatūras šūnu apoptozi, turklāt, jo izteiktāks aterosklerotiskais bojājums, jo lielāks ir apoptotiskais indekss (Bennett, Sinha and Owens, 2016). Tā kā lielāks apoptotisku gludās muskulatūras šūnu skaits konstatēts aterosklerotisku pangu zonās, kas visbiežāk plīst, pastāv uzskats, ka asinsvadu gludās muskulatūras šūnu apoptoze predisponē pangu ruptūru (Bennett, 1999). Šo teoriju apstiprina arī tas, ka pacientiem ar nestabilu stenokardiju novērots lielāks apoptotisku šūnu skaits aterosklerotiskās pangās nekā pacientiem ar stabilu stenokardiju (Bauriedel et al., 1999).

Pēc miokarda infarkta apoptozi novēro gan infarkta zonā, gan audos, kas robežojas ar infarkta zonu, turklāt maksimumu tā sasniedz 2 nedēlas pēc infarkta (Wang et al., 2018). Jāpiemin, ka dzīvnieku pētījumos agrīna reperfūzija pēc išēmijas samazināja apoptotisko 
kardiomiocītu skaitu infarkta zonā, bet palielināja apoptotisko kardiomiocītu skaitu audos gar infarkta zonu (Fliss and Gattinger, 1996). Visvairāk apoptotisko kardiomiocītu novēro tieši miokarda audos, kas robežojas ar infarkta zonu (Saraste et al., 1997). Atsevišķos pētījumos arī miokarda zonās, kas neatrodas infarkta tuvumā, novēro palielinātu daudzumu apoptotisko kardiomiocītu (Piro et al., 2000). Augsts kardiomiocītu apoptotiskais indekss novērots arī miokarda infarkta subakūtā fāzē, un tas korelē ar progresējošu kreisā kambara remodelāciju un agrīnu simptomātisku sirds mazspēju (Abbate et al., 2003). Šie pētîjumi parāda, ka apoptozei ir būtiska nozīme infarkta lieluma, kreisā kambara remodelācijas un simptomātiskas sirds mazspējas attīstībā pēc miokarda infarkta.

Pārliecinoši izteiktāka kardiomiocītu apoptoze vērojama arī aortālā vārstuḷa stenozes izraisītas kreisā kambara hipertrofijas gadījumā, turklāt apoptotiskais indekss korelē ar kreisā kambara masas indeksu (Galiuto et al., 2006). Kardiomiocītu apoptoze minēta kā viens no galvenajiem iemesliem AoV stenozes izraisītas kreisā kambara hipertrofijas dekompensācijā (Dweck, Boon and Newby, 2012). Pacientiem ar smagu AoV stenozi ir traucēta miokarda perfūzija, tātad nav atbilstošas skābekḷa piegādes skābekḷa hipertrofētajam miokardam, izraisot kardiomiocītu apoptozi (Galiuto et al., 2006).

\subsection{PGP 9.5 saturoša inervācija}

Proteīna gēna produkts 9.5 (PGP 9.5) ir neironu un neiroendokrīno šūnu citoplazmas specifisks proteīns, ko sākotnēji atklāja smadzenēs, bet šobrīd izmanto kā vispārēju marḳieri, lai vizualizētu neiropeptīdus saturošu inervāciju (Thompson et al., 1983; Üçeyler et al., 2013). PGP 9.5 ir arī kardiovaskulārās sistēmas inervācijas marḳieris (Ahmed, Johansson and FolanCurran, 1997).

Sirdi inervē sarežğîts, savstarpēji mijiedarbīgs nervšķiedru tīkls, kas nāk no centrālās nervu sistēmas, ārpus sirds esošiem ganglijiem un iekšējiem ganglijiem jeb tā sauktās sirds iekšējās nervu sistēmas (Armour, 2008). Gan pieauguša cilvēka, gan jaundzimušā veselā sirdī ir vērojams bagātīgs PGP 9.5 saturošu nervu šķiedru tīkls (Chow et al., 1995; Marron et al., 1995). Gan priekškambaros, gan kambaros PGP 9.5 saturošās nervu šķiedras pārsvarā veido perivaskulārus pinumus gar sirds vainagartērijām un tieši uz priekškambariem, tikai atsevišķas šķiedras cieši saistās ar kardiomiocītiem (Hasan, 2013; Rūmanss, Kažoka and Pilmane, 2019c). Sirds vadīšanas sistēmā tiek novērots daudz vairāk PGP 9.5 saturošu nervu šķiedru nekā pārējā priekškambaru un kambaru miokardā, turklāt to relatīvais blīvums samazinās perifēri no sinusa mezgla (Crick et al., 1994). PGP 9.5 saturošu nervu šḳiedru blīvums sirds vadīšanas sistēmā 
pieaugušajiem ir lielāks nekā jaundzimušajiem un pakāpeniski samazinās novecojot (Chow et al., 2001).

Sirds nervšķiedru remodelāciju novēro pacientiem pēc miokarda infarkta, ar sirds mazspēju un arteriālu hipertensiju (Hasan, 2013). Nervu bojājumam pēc miokarda infarkta seko pastiprināta jaunu nervu veidošanās gar bojājuma malām (Chen et al., 2001). Reǵionāla hiperinervācija savukārt saistāma ar biežāku kambaru aritmiju un pēkšṇas nāves iespēju (Cao et al., 2000; Chen et al., 2001). Turklāt dzīvnieku eksperimentos novērots, ka lokāla denervācija samazina kambaru priekšlaicīgas kontrakcijas un paaugstina kambaru aritmijas slieksni miokarda infarkta hroniskā fāzē (Liu et al., 2017).

Pastāv teorija, ka sirds autonomajai nervu sistēmai ir būtiska saistība ar priekškambaru fibrilācijas, kas ir viena no biežāk sastopamajām aritmijām pieaugušajiem, patoǵenēzi (Khan, Lip and Shantsila, 2019). Šīs teorijas pamatā ir atklājums, ka ap plaušu vēnu ietekām un priekškambaros, tajās vietās, no kurienes parasti veidojas mirdzaritmijas trigeri, ir bagātīga autonomā inervācija un ganglijus saturoši pinumi (Wickramasinghe and Patel, 2013). Turklāt šie ganglionētie pinumi ir priekškambaru fibrilācijas invazīvas ārstēšanas mērḳis (Hanna and Shivkumar, 2018).

\subsection{Audu faktori}

\subsection{1. Ātriju nātrijurētiskais peptīds}

Ātriju nātrijurētiskais peptīds (ANUP) ir hormons, kuru sintezē un producē galvenokārt priekškambaru kardiomiocīti un nelielā daudzumā arī kambaru kardiomiocīti, reaǵējot uz miokarda iestiepumu (Cannone et al., 2019). Nātrijurētiskajiem peptīdiem pieder arī smadzeņu nātrijurētiskais peptīds (BNP) un C-tipa nātrijurētiskais peptīds (Nakagawa, Nishikimi and Kuwahara, 2019). Gan ANUP, gan BNP piemīt diurētisks, nātrijurētisks un asinsvadus paplašinošs efekts, kas nodrošina arteriālā asinsspiediena un intravaskulārā tilpuma homeostāzi (Kuhn, 2012).

Nierēs ANUP palielina glomerulu filtrācijas ātrumu, kavē sāls un ūdens reabsorbciju un samazina ren̄̄na sekrēciju (Volpe, Carnovali and Mastromarino, 2016). ANUP veic koordinētu aferento arteriolu dilatāciju un eferento arteriolu konstrikciju, tādā veidā palielinot spiedienu glomerulu kapilāros un palielinot filtrācijas ātrumu (Endlich and Steinhausen, 1997).

ANUP asinsspiedienu regulē arī, inhibējot renīna-angiotenzīna-aldosterona sistēmu, ne tikai samazinot renīna sekrēciju nierēs, bet arī tiešā veidā inhibējot aldosterona produkciju virsnierēs (Chartier et al., 1984). 
ANUP darbojas ne tikai kā cirkulējošs hormons, tam piemīt arī autokrīna un parakrīna darbība. Tas samazina norepinefrīna inducētu kardiomiocītu augšanu, autokrīnā veidā pasargājot miokardu no hipertrofijas (Calderone et al., 1998). Kardiomiocītu izdalītais ANUP darbojas kā parakrīns faktors uz sirds fibroblastiem, inhibējot to augšanu un kolagēna sintēzi, tādā veidā nodrošinot antifibrotisku efektu un regulējot miokarda remodelāciju (Cao and Gardner, 1995; Maki et al., 2000). ANUP piemīt arī metabolisks efekts, tas aktivē lipāzi cilvēka tauku šūnās (Sengenès et al., 2003). Ievadot ANUP intravenozi veseliem cilvēkiem, novēro lipīdu mobilizāciju un oksidāciju, kas varētu veicināt kardiālu kaheksiju pacientiem ar smagu sirds mazspēju (Birkenfeld et al., 2005).

Pacientiem ar sirds mazspēju ir izteikti palielināts ANUP līmenis asins serumā, turklāt tā līmenis korelē ar sirds mazspējas funkcionālo klasi (Brandt et al., 1993). Lai arī sirds mazspējas gadījumā palielinātā cirkulējošā ANUP līmeņa galvenais iemesls ir hipervolēmijas izraisīts priekškambaru miokarda iestiepums, tomēr pastiprinātu ANUP sintēzi un produkciju izraisa arī endotelīns un angiotenzīns II (Hensen et al., 1992; Focaccio et al., 1993). Tā kā ANUP pussabrukšanas laiks ir 2-5 minūtes, tā noteikšanu klīniskajā praksē parasti neizmanto (Gaggin and Januzzi, 2013).

ANUP ekspresija ir palielināta miokarda infarkta zonā, kā arī ANUP līmenis asinīs ir paaugstināts pacientiem pēc akūta miokarda infarkta (Morita et al., 1993; Saito, 2010). Dzīvnieku pētījumos ANUP samazina infarkta apjomu un aizsargā miokardu no išēmijasreperfūzijas bojājuma (Nishikimi, Maeda and Matsuoka, 2006).

\subsubsection{Asinsvadu endotēlija augšanas faktors}

Asinsvadu endotēlija augšanas faktors (VEGF) ir bāzisks, heparīnu saistošs glikoproteīns, kas sākotnēji aprakstīts kā asinsvadu permeabilitātes faktors, jo tas palielina asinsvadu caurlaidību, veidojot starpšūnu spraugas, vakuolas un fenestrācijas (Bates et al., 2002). VEGF saistās ar tirozīnkināzes receptoriem, kas primāri lokalizēti uz asinsvadu endotēlija šūnu virsmas, bet atrodami arī uz citām šūnām, piemēram, acs vaskularizētajos audos - konjunktīvā, tīklenē un varavīksnenē (Kim et al., 1999). VEGF inducē endotēlija šūnu proliferāciju, migrāciju un asinsvadu caurules veidošanos gan fiziologiskos, gan patologiskos apstākḷos, piemēram, kolaterālu asinsvadu veidošanās išēmijas apstākḷlos, audzēju un iekaisuma gadījumos (Ferrara, Gerber and LeCouter, 2003). VEGF ne tikai stimulē jaunu endotēlija šūnu veidošanos, bet arī pasargā jau esošās, inducējot antiapoptotisko proteīnu ekspresiju (Gerber, Dixit and Ferrara, 1998). VEGF receptora gēns ir atrodams arī uz cilvēka monocītiem, līidz ar to VEGF inducē monocītu aktivāciju un migrāciju, tam ir būtiska nozīme iekaisuma un brūču 
dzī̌sanas procesos (Clauss et al., 1990). VEGF izraisa vazodilatāciju, inducējot endotēlija slāpekḷa oksīda sintāzi un sekojoši palielinot slāpekḷa oksīda produkciju (Hood et al., 1998).

VEGF pārsvarā producē endotēlija šūnas, bet to var producēt arī citas šūnas, piemēram, audzēju šūnas, makrofāgi, trombocīti, keratinocīti, miofibroblasti (Chintalgattu, Nair and Katwa, 2003; Corliss et al., 2016; Melincovici et al., 2018). Palielināta VEGF produkcija notiek hipoksijas apstākḷlos, bet to inducē arī vairāki citokīni, tostarp epidermālais augšanas faktors, fibroblastu augšanas faktors, tumoru nekrozes faktors $\alpha$, interleikīns 8 un citi (Ferrara, 2004; Madanecki et al., 2013). Jāatzīmē, ka tādi iekaisuma citokīni kā interleikīns 1 un interleikīns 6 arī inducē VEGF ekspresiju atsevišksās šūnu grupās, turklāt VEGF veicina iekaisuma šūnu piesaisti (Neufeld et al., 1999; Tammela et al., 2005).

Viedokḷi par VEGF nozīmi aterosklerozes veidošanās procesos nav viennozīmīgi. Imūnhistoḳīmiskie pētījumi rāda, ka agrīnas aterosklerozes gadījumos vērojama intensīva VEGF imūnreaktivitāte it sevišḳi ar makrofāgiem bagātās sabiezētas intīmas zonās (Ramos et al., 1998). VEGF reaktivitāte konstatēta arī kalcificētās biksupidālās AoV virās (Moreno et al., 2011). Turklāt oksidēta zema blīvuma lipoproteīnu klātbūtne inducē makrofāgus producēt VEGF in vitro (Ramos et al., 1998). No vienas puses, VEGF nodrošina jaunu asinsvadu veidošanos aterosklerozes skartajās zonā, bet nepilnīgi nobriedušie un trauslie asinsvadi izraisa hemorāgijas aterosklerotiskās pangas iekšienē ar sekojošu pangas nestabilitāti un plīsumu (Michel et al., 2014), kā arī VEGF darbojas kā permeabilitātes faktors, l̦aujot aterosklerotiskajiem procesiem izplatīties dziḷāk asinsvada sieniṇā (Senger et al., 1983). No otras puses, VEGF aizsargā endotēliju no bojājumu veidošanās, inducējot antiapoptotisko faktoru ekspresiju (Gerber, Dixit and Ferrara, 1998), kā arī nodrošina endotēlija atjaunošanos jau bojātā asinsvadā (Asahara et al., 1995).

Pacientiem ar neobstruktīvu hipertrofisku kardiomiopātiju ir palielināts VEGF līmenis asins serumā, salīdzinot ar veseliem cilvēkiem, turklāt pacientiem ar izteiktāku sirds mazspējas simptomātiku VEGF līmenis ir augstāks (Pudil et al., 2015). Dz̄ivnieku pētījumos AoV stenozes gadījumos ārstēšana ar VEGF palēnina sirds hipertrofijas attīstību līdz sirds mazspējai (Xu et al., 2011). Jaunākie pētījumi rāda, ka šo regulāciju parakrīnā veidā nodrošina endotēlija šūnas, caur VEGF receptoriem kontrolējot kardiomiocītu fizioloğisku augšanu (Kivelä et al., 2019).

\subsubsection{Hromogranīns A}

Hromogranīns A (ChgA) ir daudzfunkcionāls proteīns un nozīmīgs neiroendokrīnās aktivitātes marḳieris (Tota, Angelone and Cerra, 2014). Tāpat kā citi granīnu grupas proteīni tas tiek glabāts sekretorās granulās difūzi neiroendokrīnajā sistēmā un izdalīts kopā ar 
noradrenalīnu un adrenalīnu (Bartolomucci et al., 2011). ChgA šḳel, prohormonu konvertāzes katepsīns, plazmīns un kalikreīns, iegūstot tādus biologiski aktīvus peptīdus kā pankreastatīns, parastatīns, vazostatīns 1, catestatīns un serpinīns (Mahata and Corti, 2019).

Cirkulējošā ChgA līmeni palielina stresa izraisīta simpātiskās nervu sistēmas aktivācija un citi patologiiski stāvokḷi, piemēram, neiroendokrīnās sistēmas audzēji, hronisks iekaisums, hroniska sirds mazspēja (Tota, Angelone and Cerra, 2014; Marotta et al., 2018). Cirkulējošais ChgA regulē asinsvadu barjerfunkciju, inhibējot TNF inducētu endotēlija šūnu citoskeleta reorganizāciju, VEGF un trombīna izraisītu endotēlija šūnu caurlaidību (Ferrero et al., 2004). Catestatīns, viens no ChgA atvasinātiem peptīdiem, inhibē kateholamīnu atbrīvošanu virsnierēs, samazinot simpātiskās neiroendokrīnās sistēmas aktivitāti, un stimulē histamīna atbrīvošanos, izraisot vazodilatāciju un samazinot asinsspiedienu (Mahata et al., 2000; Bartolomucci et al., 2011). Pankreastatīns inhibē glikozes inducētu insulīna atbrīvošanos, regulējot glikozes līmeni (Herold et al., 2018). Serpinīnam piemīt pozitīvs inotrops efekts (Tota et al., 2012), bet vasostatīnam 1 papildus vazorelaksējošām īpašībām piemīt arī negatīvs inotrops un lusitrops efekts (Bartolomucci et al., 2011).

Veselā miokardā ChgA ir atrodams nelielā daudzumā šūnu sekretorās granulās kopā ar ANUP un BNP, bet dilatācijas un hipertrofiskās kardiomiopātijas gadījumā ir palielināts ChgA līmenis gan miokardā, gan asins plazmā (Pieroni et al., 2007). ChgA līmenis asins plazmā ir palielināts pacientiem ar arteriālu hipertensiju, turklāt pēc alfa adrenoblokatoru ievadīšanas tā līmenis asins plazmā samazinās, norādot uz vismaz daḷēju simpatoadrenālās sistēmas aktivitātes ietekmi uz hipertensiju (O’Connor, 1985). Arī sirds mazspējas un miokarda infarkta pacientiem novēro paaugstinātu ChgA līmeni asins plazmā, turklāt palielināts ChgA līmenis ir saistīts ar lielāku mirstības risku (Ceconi et al., 2002; Jansson et al., 2009). Jāatzīmē, ka pacientiem ar sirds mazspēju pēc mehānisku kambara palīgierīču implantācijas ChgA līmenis krītas (Goetze et al., 2013).

\subsubsection{Endotelīns 1}

Endotelīni ir peptīdi, kas tiek ražoti galvenokārt endotēlijā, un pirmo reizi tie izdalīti 1988. gadā no cūkas aortas endotēlija šūnām (Yanagisawa et al., 1988). Pie endotelīniem pieder trīs to izoformas - endotelīns 1, endotelīns 2 un endotelīns 3 (Agapitov and Haynes, 2002). Endotelīnu 1 (ET-1) galvenokārt sintezē un izdala asinsvadu endotēlija šūnas, bet to var producēt arī citi šūnu tipi, piemēram, kardiomiocīti, endokarda endotēlija šūnas, nieres, centrālā nervu sistēma (Davenport et al., 2016). Endotelīns 2 tiek galvenokārt producēts olšūnu folikulos, bet tas atrodams arī citos orgānos, piemēram, asinsvados, sirdī, plaušās, nierēs, un 
tam ir būtiska nozīme ovulācijā, asinsspiediena regulācijā, imunitātes nodrošināšanā un audzēju patoǵenēzē (Ling, Maguire and Davenport, 2013). Endotelīnu 3 producē virsnieru serde, tas atrodams arī sirdī, endometrijā, galvas smadzenēs, hipofìzē, bet ne endotēija šūnās (Davenport et al., 2016).

Endotelīnu bioloǵiskā aktivitāte noris, tam iedarbojoties uz diviem galvenajiem receptoriem - $\mathrm{ET}_{\mathrm{A}}$ un $\mathrm{ET}_{\mathrm{B}}$ (Maguire and Davenport, 2015). Gan $\mathrm{ET}_{\mathrm{A}}$, gan $\mathrm{ET}_{\mathrm{B}}$ atrodas asinsvadu gludās muskulatūras šūnās, sirdī, plaušu asinsvados, nierēs (Hosoda et al., 1991; Davie et al., 2002; Kohan et al., 2011). Atšķirīibā no $\mathrm{ET}_{\mathrm{A}} \mathrm{ET}_{\mathrm{B}}$ atrodas arī uz asinsvadu endotēlija šūnām (Frommer and Müller-Ladner, 2009). ET-1, saistoties pie ET $_{\mathrm{A}}$ un ET $_{\mathrm{B}}$ receptoriem asinsvadu gludajā muskulatūrā, izraisa tās konstrikciju, hipertrofiju, proliferāciju un fibrozi (Agapitov and Haynes, 2002), bet, saistoties ar $\mathrm{ET}_{\mathrm{B}}$ receptoriem endotēlija šūnās, inducē NO produkciju, kas savukārt izraisa vazodilatāciju (Schneider, Boesen and Pollock, 2007).

Tā kā ET-1 ir viens no stiprākajiem zināmajiem vazokonstriktoriem, tā cirkulējošais līmenis asinsrites sistēmā ir plaši pētīts kā potenciāls kardiovaskulāru notikumu riska faktors. Veselā sirdī ET-1 galvenais avots ir endokarda endotēlija šūnas un intramiokardiālo kapilāru endotēlija šūnas, savukārt kardiomiocīti ir mērķa šūnas (Noireaud and Andriantsitohaina, 2014). ET-1 nodrošina normālu sirds remodelāciju un pasargā kardiomiocītus no bojāejas novecošanas laikā un palielinātas pēcslodzes apstākḷos (Zhao et al., 2006). ET-1, iedarbojoties uz priekškambaru un kambaru kardiomiocītos esošajiem receptoriem, tiešā ceḷā ietekmē sirds muskuḷa funkciju (Drawnel, Archer and Roderick, 2013). ET-1 tūlītēji palielina asinsvadu gludās muskulatūras un miokarda kontraktilitāti, bet ilgtermiṇā izraisa kardiomiocītu hipertrofiju (Miyauchi and Sakai, 2019). Pacientiem ar akūtu un hronisku sirds mazspēju, kā arī pēc akūta miokarda infarkta ir palielināts ET-1 līmenis asins plazmā un tas stabilizējas pēc optimālas medikamentozas terapijas, turklāt ET-1 līmenis ir neatkarīgs agrīnas mirstības riska faktors (Omland et al., 1994; Pousset et al., 1997; Perez et al., 2016). Pacientiem ar pulmonālu hipertensiju ET-1 ir paaugstināts gan asins plazmā, gan plaušu audos, turklāt plaušu asinsvadu gludās muskulatūras šūnās ir palielināts $\mathrm{ET}_{\mathrm{A}}$ un $\mathrm{ET}_{\mathrm{B}}$ receptoru daudzums, bet samazināts $\mathrm{ET}_{\mathrm{B}}$ receptoru daudzums plaušu asinsvadu endotēlija šūnās (Tabima, Frizzell and Gladwin, 2012).

\subsection{Iekaisums}

Iekaisums ir vitāli svarīgs organisma aizsargmehānisms pret patogēniem un audu bojājumu, taču nepareiza, pārmērīga vai nepārejoša iekaisuma reakcija nodara kaitējumu veseliem audiem un ir iesaistīta daudzu akūtu un hronisku slimību patoǵenēzē (Lukens, Gross and Kanneganti, 2012). Kā viens no galvenajiem mehānismiem gan koronāras sirds slimības, 
gan deǵeneratīvas aortālas sirdskaites patoǵenēzē literatūrā minēts hronisks iekaisums (Libby, Ridker and Hansson, 2009; Mathieu and Boulanger, 2014).

Lai arī atsevišḳi ziņojumi publicēti arī agrāk, pārliecinoša doma par koronāras sirds slimības patoǵenēzes saistību ar iekaisumu parādījās pagājušā gadsimta beigās (Liuzzo et al., 1994). Iekaisumam ir svarīga loma visās aterosklerozes attīstības fāzēs, sākot ar aterosklerotisku plātņu veidošanos un beidzot ar akūtu aterosklerotiskas pangas ruptūru un trombozi (Fioranelli et al., 2018). Iekaisums ir nozīmīgs arī dzīšanas procesos pēc miokarda infarkta. Išēmija un kardiomiocītu nekroze izraisa iekaisuma citokīnu atbrīvošanos, kas piesaista neitrofilos leikocītus un monocītus, kas savukārt veicina miofibroblastu un endotēlija šūnu augšanu un diferenciāciju. Aktivizēti miofibroblasti producē matrices olbaltumvielas, formējot rētu (Frangogiannis, 2014).

Stenotisku aortālo vārstuḷu virās tāpat kā aterosklerotiskās pangās ir vērojama hroniska iekaisuma šūnu infiltrācija (makrofāgi un T limfocīti) un palielināta iekaisuma citokīnu izdale (Zakynthinos and Pappa, 2009; Leopold, 2013). Turklāt T limfocītu infiltrācija raksturīga arī kalcificētiem divviru aortāliem vārstuḷiem (Wallby et al., 2002). Viens no citokīniem, kura ekspresija ir palielināta stenotisku aortālo vārstuḷu virās, ir interleikīns $1 \beta$, turklāt veselu vārstuḷu virās tas nav atrodams (Freeman and Otto, 2005). Veselu aortālo vārstuḷu intersticiālās šūnas interleikīna $1 \beta$ ietekmē maina fenotipu un producē tādus proinflammatorus citokīnus kā interleikīns 6 un interleikīns 8 (Nadlonek et al., 2013).

Pašreizējie pētījumi liecina, ka sirds mazspēja faktiski ir pastāvīgs hronisks iekaisuma stāvoklis, kurā iekaisuma citokīniem, tostarp tumora nekrozes faktoram alfa, interleikīniem 1, 6 un 18, ir būtiska loma tūlītējas atbildes reakcijas veidošanā, nodrošinot šūnu aizsardzību un miokarda remodelāciju (Linde et al., 2007). Turklāt iekaisuma citokīnu un hemokīnu līmenis asin̄̄s korelē ar sirds mazspējas funkcionālo klasi un sirds funkcionālajiem parametriem, piemēram, kreisā kambara izsviedes frakciju (Torre-Amione et al., 1996). Palielināts daudzums iekaisuma marḳieru sirds mazspējas gadījumā konstatēts ne tikai asins serumā, bet arī miokardā (Devaux et al., 1997; Damås et al., 2000). Lai arī mērena citokīnu reakcija varētu būt aizsargājoša, neatbilstoša un pārmērīga iekaisuma reakcija ir patologiiska (Mann, 2002).

C reaktīvais olbaltums $(\mathrm{CRO})$ ir akūtās fāzes proteīns, kas tiek sintezēts aknās un ir sensitīivs sistēmiskas iekaisuma reakcijas marḳieris (Black, Kushner and Samols, 2004). CRO ir intensīvi pētīts aterosklerozes un koronāras sirds slimības pacientiem. Paaugstināts CRO līmenis ir saistîts ar paaugstinātu kardiovaskulāro notikumu risku pacientiem ar KSS, bet tam nav konstatēta saistība ar aortālā vārstuḷa viru sklerozi, stenozes progresu vai smagas aortālā vārstuḷa stenozes esamību (Small et al., 2017). Normāls CRO līmenis pacientiem bez 
aterosklerotiskām izmain̄ām koronārajos asinsvados, bet ar stenokardijas tipa sāpēm un miokarda išēmiju koronāro asinsvadu spazmas dēl norāda, ka iekaisuma akūtās fāzes iemesls nav miokarda išēmija, bet, visticamāk, atspoguḷo iekaisuma reakciju aterosklerotiskās koronārajās artērijās (Hansson, 2005). Lai arī pacientiem ar kritisku simptomātisku deǵeneratīvu aortālā vārstuḷa stenozi ir konstatēts lielāks CRO līmenis nekā veseliem indivīdiem (Galante et al., 2001), šī saistība neapstiprinājās, veicot lielu kohortas pētījumu, kurā iekḷāva 5201 pacientu, no kuriem 9 \% pētījuma laikā aortālā vārstuḷa viru skleroze progresēja līdz dažādas pakāpes stenozei (Novaro et al., 2007).

\subsubsection{Interleikīns $1 \alpha$}

Dinarello et al. 1974. gadā pirmo reizi aprakstīja 2 cilvēka pirogēnus, ko ieguva no veselu donoru monocītiem un neitrofiliem leikocītiem (Dinarello, Goldin and Wolff, 1974) un vēlāk nosauca par interleikīnu $1 \alpha$ un interleikīnu $1 \beta$ (Di Paolo and Shayakhmetov, 2016). Šobrīd Il-1 saimē ir aprakstīti 11 citokīni ar līdzīgu vai atšḳirīgu bioloǵisko iedarbību (Kaneko et al., 2019). Interleikīns $1 \alpha$ ir iekaisuma citokīns, kas atrodams lielākajā daḷā organisma šūnu, tostarp limfoīdo orgānu makrofāgos (tīmusā, liesā, limfmezglos, kaulu smadzenēs), kuṇǵa un zarnu trakta epitēlija šūnās, plaušās, aknās, nierēs, endotēlija šūnās un astrocītos (Garlanda, Dinarello and Mantovani, 2013; Kaneko et al., 2019). Il-1 $\alpha$ tiek sintezēts šūnā kā prekursors pro-Il-1 $\alpha$, kas ir bioloğiski aktīvs, un to šḳel, enzīms kalpaīns, veidojot nobriedušu proteīnu (Bujak and Frangogiannis, 2009). Stresa, piemēram, išēmijas vai infekcijas, apstākḷos, šūnai ejot bojā nekrozes ceḷā, Il-1 $\alpha$ izdalās apkārtējā vidē, turklāt tā ekspresija šūnās hipoksijas apstākḷıs ir palielināta jau pirms šūnas nāves (Rider et al., 2011). Nonākot starpšūnu telpā, Il- $1 \alpha$ saistās ar Il-1 receptoriem un darbojas kā trauksmes signāls, piesaistot neitrofilos leikocītus un inducējot sterilu iekaisuma reakciju ar mērḳi atdalīt kaitīgo faktoru, aizvākt atmirušās šūnas un uzsākt dzī̌sanas procesu (Rider et al., 2011; Lukens, Gross and Kanneganti, 2012). Apoptozes gadījumā Il-1 $\alpha$ no citosola pārvietojas uz šūnas kodolu, kur cieši saistās ar hromatīnu un nespēj inducēt iekaisuma reakciju (Garlanda, Dinarello and Mantovani, 2013).

Il-1 $\alpha$ reti ir atrodams cirkulācijā, tas nav atrodams asins plazmā ne pacientiem ar stabilu KSS, ne pacientiem ar akūtu koronāru sindromu (Heinisch et al., 2005).

Anakinra ir Il-1 konkurējošs receptoru antagonists, kas bloḳē gan Il-1 $\alpha$, gan Il-1 $\beta$ biologiiskos efektus un ko izmanto reimatoīdā artrīta ārstēšanā (Szekely and Arbel, 2018). Tā ievadīšana $24 \mathrm{~h}$ laikā pēc akūta miokarda infarkta nozīmīgi samazina kardiomiocītu apoptozi un kreisā kambara palielināšanos pelēm (Abbate et al., 2008). Eksperimentālos modeḷos Il-1 novērots negatīvs inotrops efekts (Hosenpud, Campbell and Mendelson, 1989). To apstiprina 
arī tas, ka pacientiem ar reimatoīdo artrītu un bez zināmām sirdskaitēm pēc Il-1 receptoru antagonista ievadīšanas novēro kreisā kambara funkcijas uzlabošanos (Ikonomidis et al., 2008). Līdzīgas tendences, taču bez nozīmīga klīniskā efekta novērotas 2 pilotpētījumos ar pacientiem pēc miokarda infarkta ar ST elevācijām. Abbate et al. 2013. gadā publicēja randomizēta, placebo kontrolēta pilotpētījuma rezultātus, kur pacientiem, kuri pēc akūta koronāra sindroma ar ST elevācijām papildus standarta terapijai saņēma anakinru, novēroja mazāku kreisā kambara remodelāciju, kas korelēja ar C-reaktīvā olbaltuma līmeṇa samazināšanos asinīs (Abbate et al., 2013). Pētījumā, kurā pacienti ar akūtu koronāru sindromu bez ST elevācijām papildus standarta terapijai saņēma anakinru vai placebo 14 dienas, netika konstatētas atšķirības lielu, nelabvēlīgu kardiālu notikumu ziṇā ne 30 dienu, ne 3 mēnešu periodā (Morton et al., 2015). Taču šajā pašā pētījumā 1 gada periodā pacientiem, kuri pēc akūta koronāra sindroma bez ST elevācijām saṇēma Il-1 receptoru antagonistu, bija vairāk lielu, statistiski ticamu, nelabvēlīgu kardiālu notikumu nekā placebo grupā.

\subsubsection{Interleikīns 10}

Interleikīns 10 (Il-10) ir spēcīgs pretiekaisuma citokīns, kas bloḳē imūnās reakcijas dažādos līmeņos, kavējot proinflammatoro citokīnu izdali un šūnu proliferāciju (Joss et al., 2000; Saxena et al., 2015). Galvenais Il-10 avots organismā ir T limfocīti (Th2, Tr1, Th1, Th17), taču to producē arī monocīti, atbilstoši aktivēti makrofāgi, dendrītiskās šūnas, B limfocīti, eozinofilie leikocīti, keratinocīti, epitēlija šūnas (Mosser and Zhang, 2008). Il-10 saistās ar Il-10 receptoriem (Il-10R), kas sastāv no 2 proteīnu ḳēēem Il-10R1 un Il-10R2, veidojot Il-10/Il-10R kompleksus (Shouval et al., 2014).

Tā kā ateroskleroze ir iekaisīgs process, pangas stabilitāti nosaka attiecība starp proinflammatoro un antiinflammatoro citokīnu darbību. Pacientiem ar nestabilu stenokardiju Il-10 ekspresija ir palielināta aterosklerotiskās pangās, galvenokārt makrofāgos (Nishihira et al., 2006), bet asins serumā Il-10 līmenis ir mazāks nekā pacientiem ar stabilu slodzes stenokardiju (Smith et al., 2001). Taču literatūrā ir pieejami pretrunīgi dati par Il-10 līmeni kā prognostisku faktoru pacientiem ar akūtu miokarda infarktu. Pacientiem ar akūtu miokarda infarktu ar ST elevācijām palielināts Il-10 līmenis asins serumā ir saistāms ar palielinātu 30 dienu mirstību (Yip et al., 2007), bet citā pētījumā pacientiem ar akūtu koronāru sindromu bez ST elevācijām un palielinātu Il-10 līmeni asins serumā 30 dienu un 6 mēnešu periodā bija ievērojami mazāka mirstība (Heeschen et al., 2003). 
Il-10 piemīt arī gan fibrozi veicinoša, gan arī antifibrotiska iedarbība. Infarkta zonā galvenais Il-10 avots ir makrofāgi, turklāt tā produkcija ir atkarīga no laika, kas pagājis pēc miokarda infarkta. 10 dienas pēc infarkta gandrīz visi infarkta zonā esošie makrofāgi producē Il-10 (Troidl et al., 2009). Il-10, ko ražo miokarda makrofāgi, netieši inducē miofibroblastu aktivāciju un kolagēna izgulsnēšanos, veidojot rētu, taču tā rezultātā miokards kḷūst neelastīgs un attīstās diastoliska mazspēja (Hulsmans et al., 2018). Specifiska Il-10 gēna delēcija no makrofāgiem un monocītiem pelēm uzlaboja diastolisko funkciju, samazinot kreisā kambara beigu diastoles spiedienu un uzlabojot relaksāciju diastoles laikā (Cihakova, 2018). Salīdzinot sirds mazspējas pacientus ar saglabātu un samazinātu kreisā kambara izsviedes frakciju, lielāks Il-10 līmenis asins serumā konstatēts pacientiem ar sirds mazspēju un saglabātu kreisā kambara izsviedes frakciju, tātad diastolisku disfunkciju (Perticone et al., 2019).

Il-10 iedarbībai ir aprakstīts arī antifibrotisks efekts. Miokardā spiediena pārslodzes dēl nonāk fibroblastu cilmes šūnas no kaulu smadzenēm, Il-10 kavē to diferenciāciju par miofibroblastiem, līdz ar to kavējot miokarda fibrozi (Verma et al., 2018). Il-10 ievadīšana dzīvnieku eksperimentos samazina spiediena pārslodzes izraisītu miokarda hipertrofiju un fibrozi, pasargājot sirds funkciju (Verma et al., 2013).

\subsection{Beta defensīni}

Defensīni ir mazi, ar cisteīnu bagāti multifunkcionāli katjonu protē̄ni ar antimikrobo efektivitāti pret baktērijām, sēnēm un vīrusiem (Kougias et al., 2005). Taču tiem raksturīga ne tikai antimikroba iedarbība, bet arī pretvēža un mitogēna aktivitāte, tiem ir nozīme signālu pārvadē un adaptīvās imunitātes nodrošināšanā (Kamysz, Okrój and Łukasiak, 2003). Cilvēka $\beta$ defensīnus producē galvenokārt epitēlija šūnas, un tie nodrošina pirmās līnijas aizsardzību pret mikroorganismiem (Cobo and Chadee, 2013). Vairākos pētījumos ir aprakstīta $\beta$ defensīnu ekspresija dažādu sugu dzīvnieku visas sirds homogenātā (Linde et al., 2013). Visi līdz šim aprakstītie $\beta$ defensīni in vitro nomāc vai spēj iznīcināt plašu baktēriju un sēṇu spektru. Antimikrobās darbības pamatā ir mijiedarbība starp $\beta$ defensīnu pozitīvo lādiṇu un mikroorganismu negatīvi lādētām membrānām, izraisot to depolarizāciju un nāvi (Falanga et al., 2017).

Beta defensīns 1 sākotnēji tika identificēts dialīzes pacientu hemofiltrātā, bet vēlāk tas atrasts daudzu orgānu epitēlija šūnās, tostarp ādā, aizkungǵa dziedzerī, elpceḷos, smaganās, dzimumorgānos un nierēs (Ali et al., 2001; Ghosh, McCormick and Weinberg, 2019). $\beta$ D1 piemīt baktericīda aktivitāte pret Gram pozitīvām un Gram negatīvām baktērijām, kā arī spēja inaktivēt Candida sugas sēnes (Winter and Wenghoefer, 2012). $\beta$ D1 ekspresija audos 
lielākoties ir pastāvīga, to neietekmē infekcijas klātbūtne (O’Neil et al., 1999). Mainīta - gan palielināta, gan samazināta - $\beta$ D1 ekspresija konstatēta vairāku audzēju gadījumos (Ghosh, McCormick and Weinberg, 2019).

Beta defensīns 2 pirmo reizi tika atklāts cilvēka ādā 1997. gadā (Harder et al., 1997), vēlāk tas aprakstīts daudzu orgānu epitēlija šūnās, arī plaušās un kungǵa zarnu traktā (Bals et al., 1998; Bals, 2000). Pretstatā $\beta D 1$ pamata $\beta D 2$ ekspresija audos ir zema, bet tā palielinās infekcijas un iekaisuma citokīnu ietekmē (Leonard, Affolter and Bevins, 2012). Cilvēka ādas brūcēs $\beta D 2$ ekspresiju inducē epidermas augšanas faktoru receptoru aktivizācija, un tas palielina keratinocītu citokīnu produkciju un migrāciju (Mangoni, McDermott and Zasloff, 2016). $\beta D 2$ ir baktericīda aktivitāte pret Gram negatīvām baktērijām un Candida albicans, bet tas ir samērā neefektīvs pret Gram pozitīvajiem Staphylococcus aureus (Huttner and Bevins, 1999). $\beta D 2$ ietekme uz vīrusiem ir samērā neskaidra, un tā nozīme šobrīd tiek aktīvi pētīta, piemēram, ir zināms, ka $\beta \mathrm{D} 2$ samazina Varicella zoster vīrusa koncentrāciju 10 dienas pēc inficēšanās, bet ne agrākā slimības etapā (Wilson, Wiens and Smith, 2013). Tāpat kā $\beta D 1$, arī ßD2 ekspresijas līmenis audzēju gadījumos ir atkarīgs no audzēja veida un lokalizācijas. Piemēram, barības vada plakanšūnu karcinomas audos novēro palielinātu $\beta D 2$ ekspresiju (Shi et al., 2014), bet resnās zarnas audzēja audos $\beta$ D2 RNS ekspresija bija ievērojami mazāka nekā veselos resnās zarnas audos (Semlali et al., 2015).

Beta defensīns 3 ir vēl viens antimikrobais peptīds, kas sākotnēji tika izdalīts no psoriāzes skartas cilvēka ādas (Harder et al., 2001). Vēlāk tas atrasts arī citu orgānu epitēlija šūnās, piemēram, mandelēs, barības vadā, trahejā, resnajā zarnā un dzemdes kaklā (Semlali et al., 2015; Xu et al., 2016; Ghosh, McCormick and Weinberg, 2019). $\beta$ D3 atrodams ne tikai epitēlija audos, bet arī cilvēka miokardā un skeleta muskulatūrā (García et al., 2001; Jia et al., 2001). ßD3 ekspresiju audos inducē mikroorganismu klātbūtne un iekaisuma citokīni, piemēram, tumora nekrozes faktors $\alpha$, interferons $\gamma$ (García et al., 2001; Harder et al., 2001). Līdzīgi kā $\beta D 2$, arī $\beta D 3$ piemīt stipra baktericīda iedarbība pret Gram negatīvām baktērijām un raugiem, bet tas darbojas arī pret Gram pozitīvām baktērijām, piemēram, Streptococcus pyogenes un Staphylococcus aureus, ieskaitot multirezistentus Staphylococcus aureus celmus un pat dažus vīrusus (Dutta and Das, 2015; Jiang et al., 2016). $\beta$ D3 piemīt izteiktāka antibakteriālā iedarbība, salīdzinot ar $\beta \mathrm{D} 1$ un $\beta \mathrm{D} 2$. Tāpat kā $\beta \mathrm{D} 1$ un $\beta \mathrm{D} 2$, arī $\beta \mathrm{D} 3$ ekspresijas regulācija audzēju audos ir atkarīga no to lokalizācijas un veida (Ghosh, McCormick and Weinberg, 2019). Lielā daudzumā $\beta D 3$ ir atrodams keratinocītos ādas brūcēs, kur tas veicina citokīnu sekrēciju, šūnu migrāciju un proliferāciju, turklāt dzīvnieku pētījumos lokālās 
aplikācijās tas ievērojami palielina brūces slēgšanās ātrumu (Mangoni, McDermott and Zasloff, 2016).

Beta defensīns 4 tika atklāts 2001. gadā (Garcia et al., 2001). Pretstatā iepriekš pieminētajiem $\beta$ defensīniem, kas atrodami lielākajā daḷā orgānu, $\beta$ D4 ekspresija līdz šim konstatēta tikai atsevišķu orgānu epitēlija šūnās, piemēram, sēkliniekos, kuṇgīi, dzemdē, vairogdziedzerī, plaušās un nierēs (Garcia et al., 2001). $\beta$ D4 piemīt baktericīda iedarbība uz Pseudomona aeruginosa (Prahl et al., 2016). 


\section{Materiāli un metodes}

Pētījumā izmantotais audu materiāls - labā priekškambara austiņas fragmenti no 36 unikāliem pacientiem - iegūts Paula Stradiṇa Klīniskās universitātes slimnīcas Sirds ķirurg̣ijas centrā plānveida sirds operāciju laikā posmā no 2014. līdz 2017. gadam. Pētījums veikts atbilstoši Helsinku deklarācijai un Rīgas Stradiņa universitātes ētikas prasībām (Ētikas komitejas sēdes datums 29.05.2014.) (skatīt 1. pielikumā). Visi paraugi ņemti ar pacientu rakstisku piekrišanu.

Pirms operācijas visiem pacientiem veikti rutīnas izmeklējumi, kā parasti pirms plānveida sirds operācijām, tostarp ehokardiogrāfija un koronarogrāfija (KG), asins analīzēs noteikts $\mathrm{C}$ reaktīvais olbaltums (CRO), holesterīna frakcijas, tai skaitā triglicerīdi, kopējais holesterīns, augsta un zema blīvuma holesterīns, atsevišķiem pacientiem arī smadzeņu nātrijurētiskais peptīds (BNP). Pēc triglicerīdu līmeņa asins plazmā pacienti tika iedalīti 2 grupās: $<1,7 \mathrm{mmol} / \mathrm{L}$ un $\geq 1,7 \mathrm{mmol} / \mathrm{L}$, pēc ZBLH līmeņa pacientus iedalīja 4 grupās: $<$ 1,8 mmol/L; 1,81-2,5 mmol/L; 2,5-3mmol/L un > $3 \mathrm{mmol} / \mathrm{L}$, bet pēc ABLH līmeṇa 2 grupās: $\geq 1,2 \mathrm{mmol} / \mathrm{L}$ un $<1,2 \mathrm{mmol} / \mathrm{L}$ (Mach et al., 2020). No pacientu slimības vēsturēm apkopoti anamnēzes dati par cukura diabētu, mirdzaritmiju un statīnu lietošanu. Pacientiem ar cukura diabētu nozīmīgas faktoru sadalījuma atšķirības nekonstatējām, tādēl cukura diabēta iespējamo ietekmi darbā neapskatījām. Visiem pacientiem pirms operācijas veikta ehokardiogrāfija, kur noteikts labā priekškambara laukums, kreisā kambara izsviedes frakcija procentos (KKEF), labā kambara sistoliskais spiediens. Kreisā kambara izsviedes frakcija ir viens no biežāk lietotajiem kreisā kambara sistoliskās funkcijas parametriem, pēc kura pacientus iedalīja vairākās grupās - normāla KKEF EF 52-72 \%, viegli samazināta KKEF 41-51 \%, mēreni samazināta 30-40 \%, izteikti samazināta KKEF < 30 \% (Lang et al., 2015; Cosyns et al., 2017). Labā kambara sistoliskais spiediens (LKSS) atspoguḷo spiedienu plaušu artērijās, pēc LKSS pacientus iedalīja šādās grupās: normāls LKSS <40 mmHg, viegli paaugstināts LKSS 41-55 mmHg, mēreni paaugstināts 55-70 mmHg un izteikti paaugstināts LKSS > $70 \mathrm{mmHg}$ (Kaddoura, 2009). Labais priekškambaris ehokardiogrāfiski tika izvērtēts, izmērot labā priekškambara laukumu (RAA) - normāls RAA $\leq 18 \mathrm{~mm}^{2}$, palielināts RAA $>18 \mathrm{~mm}^{2}$ (Rudski et al., 2010). 


\subsection{Pētījuma pacientu raksturojums}

Kopā pētījumā iekḷauti 36 pacienti ar iegūtām sirdskaitēm - 24 pacienti ar koronāru sirds slimību un 12 pacienti ar deǵeneratīvu aortālā vārstuḷa stenozi. Pacientu pirmsoperācijas dati apkopoti 2.1. tabulā. KSS grupā vidējais pacienta vecums (vidējais \pm SD) bija $65 \pm 8,6$ gadi (no 52 līdz 80 gadiem), bet AoV stenozes grupā $69 \pm 10,1$ gads (no 52 līdz 83 gadiem), turklāt starp šiem rādītājiem nav statistiski ticamu atšḳirību (p 0,653). No pacientu anamnēzes zināms, ka vismaz viena mirdzaritmijas epizode bijusi 1 pacientam KSS grupā un 3 pacientiem AoV stenozes grupā. Kaut gan lielākā daḷa - 79,2 \% - no KSS grupas pacientiem pastāvīgi lieto statīnus, 6 pacientiem bija izteikti paaugstināts ZBLH līmenis - virs $3 \mathrm{mmol} / \mathrm{L}$ - un tikai 11 pacientiem jeb 45,8 \% ZBLH līmenis asins plazmā bija mazāks par 1,8 mmo/L, turklāt tikai 16,7 \% pacientu KSS grupā ABLH līmenis bija augstāks par 1,2 mmol/L. Paaugstināts iekaisuma rādītājs CRO lielākajai daḷai pacientu bija gan KSS, gan AoV stenozes grupā, attiecīgi 79,2 \% un 91,7\% pacientu. Saglabāta kreisā kambara sistoliskā funkcija bija 16 pacientiem KSS grupā un piln̄̄gi visiem pacientiem AoV stenozes grupā. Palielināts labais priekškambaris bija 4 pacientiem KSS grupā un 3 pacientiem AoV stenozes grupā, bet pulmonālas hipertensijas ehokardiogrāfiskas pazīmes bija 2 pacientiem ar KSS un 3 pacientiem ar deǵeneratīvu AoV stenozi.

2.1. tabula

Pêtījuma pacientu raksturojums

\begin{tabular}{|c|c|c|c|}
\hline \multirow{2}{*}{ Diagonoze } & \multirow{2}{*}{$\begin{array}{l}\text { Nosakāmie } \\
\text { lielumi }\end{array}$} & KSS & Deǵeneratìva AoV stenoze \\
\hline & & $\mathrm{n}(\%), \mathrm{n}=24$ & $\mathrm{n}(\%), \mathrm{n}=12$ \\
\hline \multicolumn{2}{|l|}{ Vīrieši } & $18(75,0)$ & $4(33,3)$ \\
\hline \multicolumn{2}{|l|}{ Cukura diabēts } & $5(20,8)$ & $4(33,3)$ \\
\hline \multicolumn{2}{|l|}{ Statīnu lietošana } & $19(79,2)$ & $9(75,0)$ \\
\hline \multicolumn{2}{|l|}{ Mirdzaritmija } & $1(4,2)$ & $3(25,0)$ \\
\hline \multicolumn{2}{|l|}{ TG, mmol/L } & $\mathrm{n}=23$ & - \\
\hline & $<1,7$ & $15(62,5)$ & $8(66,7)$ \\
\hline & $\geq 1,7$ & $8(33,3)$ & $4(33,3)$ \\
\hline \multicolumn{2}{|l|}{ ZBLH, mmol/L } & $\mathrm{n}=22$ & - \\
\hline & $<1,8$ & $11(45,8)$ & $4(33,3)$ \\
\hline & $1,81-2,5$ & $5(20,8)$ & $4(33,3)$ \\
\hline & $2,51-3,0$ & $0(0)$ & $2(16,7)$ \\
\hline & $>3,0$ & $6(25,0)$ & $2(16,7)$ \\
\hline \multicolumn{2}{|l|}{ ABLH, $\mathrm{mmol} / \mathrm{L}$} & $\mathrm{n}=23$ & - \\
\hline & $\geq 1,2$ & $4(16,7)$ & $10(83,3)$ \\
\hline & $<1,2$ & $19(79,2)$ & $2(16,7)$ \\
\hline \multicolumn{2}{|l|}{ CRO, mg/l } & - & - \\
\hline & $\leq 5,0$ & $19(79,2)$ & $11(91,7)$ \\
\hline & $>5,0$ & $5(20,8)$ & $1(8,3)$ \\
\hline
\end{tabular}


2.1. tabulas turpinājums

\begin{tabular}{|c|c|c|c|}
\hline \multirow{2}{*}{ Diagonoze } & \multirow{2}{*}{$\begin{array}{l}\text { Nosakāmie } \\
\text { lielumi }\end{array}$} & KSS & Degeneratīva AoV stenoze \\
\hline & & $\mathrm{n}(\%), \mathrm{n}=24$ & $\mathrm{n}(\%), \mathrm{n}=12$ \\
\hline \multicolumn{2}{|l|}{ KKEF, \% } & - & - \\
\hline & $>52$ & $16(66,7)$ & $12(100)$ \\
\hline & $41-51$ & $5(20,8)$ & $0(0)$ \\
\hline & $30-41$ & $3(12,5)$ & $0(0)$ \\
\hline & $<30$ & $0(0)$ & $0(0)$ \\
\hline \multicolumn{2}{|l|}{$\mathbf{R A A}, \mathbf{c m}^{2}$} & - & - \\
\hline & $\leq 18$ & $20(83,3)$ & $9(75,0)$ \\
\hline & $>18$ & $4(16,7)$ & $3(25,0)$ \\
\hline \multicolumn{2}{|l|}{ LKSS, mmHg } & - & - \\
\hline & $<40$ & $22(91,7)$ & $9(75,0)$ \\
\hline & $41-55$ & $1(4,2)$ & $2(16,7)$ \\
\hline & $56-70$ & $1(4,2)$ & $1(8,3)$ \\
\hline & $>70$ & $0(0)$ & $0(0)$ \\
\hline
\end{tabular}

* Apzīmējumi: ABLH - augsta blīvuma holesterīns, AoV - aortālais vārstulis, CRO - C-reaktīvais olbaltums, KKEF - kreisā kambara izsviedes frakcija, KSS - koronāra sirds slimība, LKSS - labā kambara sistoliskais spiediens, RAA - labā priekškambara laukums, TG - triglicerīdi, ZBLH - zema blīvuma holesterīns.

\subsection{Kontroles grupas pacientu raksturojums}

Kā pētījuma kontroles grupa izmantoti Rīgas Stradiṇa universitātes Anatomijas un antropolog̣ijas institūta arhīvā esoši labā priekškambara audu paraugi no 5 pacientiem ar iedzimtām sirdskaitēm, kas operēti agrīnā vecumā. Pētījums veikts atbilstoši Helsinku deklarācijai un Rīgas Stradina universitātes ētikas prasībām (Ētikas komitejas sēdes datums 30.04.2015) (skatīt 1. pielikumā).

Kontroles grupas pacientu dati apkopoti 2.2. tabulā. Šajā grupā pacienti bija vecumā no 16 dienām līdz 1 gadam un 2 mēnešiem.

2.2. tabula

Kontroles grupas pacientu raksturojums

\begin{tabular}{|l|l|l|l|}
\hline Nr. & \multicolumn{1}{|c|}{ Dzimums } & \multicolumn{1}{|c|}{$\begin{array}{c}\text { Vecums } \\
\text { operācijas dienāa }\end{array}$} & \multicolumn{1}{c|}{ Diagnoze } \\
\hline 1. & Zēns & 16 dienas & $\begin{array}{l}\text { Plaušu artērijas un trikuspidālā vārstuḷa atrēzija. } \\
\text { Hipoplastisks labais kambaris. Koronāras fistulas. } \\
\text { Atvērts arteriālais vads. }\end{array}$ \\
\hline 2. & Meitene & 6 mēneši & Kambaru starpsienas defekts. Atvērts arteriālais vads. \\
\hline 3. & Meitene & 6 mēneši & Fallo tetrāde \\
\hline 4. & Zēns & 1 gads 2 mēneši & Kambaru starpsienas defekts \\
\hline 5. & Zēns & 4 mēneši & Kambaru starpsienas defekts \\
\hline
\end{tabular}




\subsection{Audu griezumu iegūšana un sagatavošana krāsošanai}

Sirds operācijas veiktas pilnā intubācijas narkozē ar gareniskas sternotomijas pieeju. $\sim 2 \mathrm{~mm}^{2}$ lieli audu fragmenti ņemti no iegriezuma vietas labajā priekškambarī, kas paredzēta venozās kaniles ievietošanai. Pirms kaniḷu ievietošanas pacienti saṇēmuši 300 DV/kg heparīna, lai novērstu trombu veidošanos mākslīgās asinsrites laikā (Chikwe, Beddow and Glenville, 2006). Pacientiem netika veikti nekādi papildu iegriezumi, līdz ar to netika nodarīts nekāds papildu kaitējums. Audu fragmenti ņemti pirms mākslīgās asinsrites uzsākšanas un nekavējoties ievietoti iepriekš sagatavotās Ependorfa tipa mēǵenēs ar piesātinātu pikrīnskābes šķīdumu jeb Stefanini šķīdumu. Stefanini šķīdums sastāv no $2 \%$ formaldehīda un 0,2 \% pikrīnskābes $0,1 \mathrm{M}$ fosfâta buferšķ̄idumā $(\mathrm{pH}$ 7,2) un ir paredzēts audu fiksācijai (Stefanini, de Martino and Zamboni, 1967). Tālāk audu fragmentus transportēja uz Rīgas Stradiṇa universitātes Anatomijas un antropolog̣ijas institūta Morfologijas laboratoriju, kur veica audu dehidratāciju ar dažādas koncentrācijas spirtu (spirts $70^{\circ}-1$ stunda, spirts $80^{\circ}-1$ stunda, spirts $96^{\circ}-2$ reizes pa 2 stundām, spirts $96^{\circ}-3$ stundas, ksilols -2 reizes pa 1 stundai). Pēc tam materiālu ieguldīja parafīnā un ar Leica RM 2245 mikrotomu pagatavoja $3 \mu \mathrm{m}$ plānus griezumus. Griezumus izlīdzināja silta ūdens peldē $\left(40-54{ }^{\circ} \mathrm{C}\right.$ temperatūrāa), pārnesa uz priekšmetstikliṇiem un izžāvēja. Tālāk griezumus sagatavoja krāsošanai deparafinizēja ksilolā (3 reizes pa 5 minūtēm) un rehidratēja ar dilstošas koncentrācijas spirta šķīdumiem (spirts $96^{\circ}-2$ reizes pa 3 minūtēm, spirts $70^{\circ}-3$ minūtes). Pēc tam audus krāsoja ar hematoksilīnu un eozīnu rutīnas gaismas mikroskopijai, apstrādāja pēc biotīna-streptavidīna metodes imūnhistoḳīmiskai audu marķieru noteikšanai un pēc TUNEL metodes apoptotisku šūnu noteikšanai.

\subsection{Rutīnas gaismas mikroskopija}

Rutīnas gaismas mikroskopijai preparātus krāsoja ar hematoksilīnu un eozīnu (Fischer et al., 2008). Pēc rehidratācijas audus skaloja destilētā ūdenī un krāsoja ar hematoksilīnu (ab143166, Abcam, ASV) 10 min., lai vizualizētu šūnu kodolus. Tālāk audus skaloja tekošā ūden̄̄ 5 minūtes un krāsoja ar eozīnu (05B1003, Bio-Optica, Itālija) 1 minūti, lai vizualizētu citoplazmu. Pēc tam audus atkārtoti skaloja tekošā ūdenī, dehidratēja ar augošas koncentrācijas spirta šķ̄īumu (spirts $70^{\circ}-3$ minūtes, spirts $96^{\circ}-2$ reizes pa 3 minūtēm), pārklāja ar karboksilolu 2 minūtes un ksilolu divas reizes pa 3 minūtēm. Tālāk preparātu fiksēja ar histologiisko līmi (00811, HistoLab, Zviedrija) un pārklāja ar segstikliṇu. Visus preparātus izvērtēja Leica VM 6000B gaismas mikroskopā. 


\subsection{Imūnhistoḳīmija}

Ar imūnhistoḳīmijas metodi labā priekškambara audos noteikti šādi marḳieri: ātriju nātrijurētiskais peptīds (ANUP), PGP 9.5 saturoša inervācija, asinsvadu endotēlija augšanas faktors (VEGF), hromogranīns A (ChgA), endotelīns 1 (ET-1), interleikīns $1 \alpha$ (Il-1 $\alpha)$, interleikīns 10 (Il-10), $\beta$ defensīni 2, 3 un 4 (attiecīgi $\beta$ D2, $\beta$ D3 un $\beta$ D4). Audu griezumus krāsoja pēc biotīna-streptavidīna metodes (Hsu, Raine and Fanger, 1981). Pēc rehidratācijas audus skaloja ar TRIS bufera šḳīdumu (15-M106, Bio-Optica, Itālija) 2 reizes pa 5 minūtēm un tikpat ilgi vārīja EDTA bufera šķīdumā (T0103, Diapath, Itālija). Pēc tam audu paraugus apstrādāja ar $3 \%$ peroksīdu 10 minūtes, lai bloḳētu endogēno peroksidāzi, un atkārtoti skaloja ar TRIS bufera šķīdumu 2 reizes pa 5 minūtēm. Tālāk audus vienu stundu apstrādāja ar šādām primārām antivielām:

- ANUP - 8515/6, darba atšķaidījums 1:10, Dako, Dānija;

- PGP 9.5 - 439273A, darba atšķaidījums 1:200, Invitrogen, ASV;

- VEGF - SC7269, darba atšķaidījums 1:50, Santa Crus Biotechnology, Inc., ASV;

- ChgA - 910216A, darba atšķaidījums 1:100, Invitrogen, ASV;

- ET-1 - ab2786, darba atšķaidījums 1:250, Abcam, Lielbritānija;

- Il-1 $\alpha$ - sc-9983, darba atšķaidījums 1:50, Santa Cruz Biotechnology, Inc., ASV;

- Il-10 - ab34843, darba atšķaidījums 1:400, Abcam, Lielbritānija;

- $\beta \mathrm{D} 2$ - AF2758, darba atšķaidījums 1:100, R\&D Systems, Vācija;

- $\beta$ D3 - orb183268, darba atšķaidījums 1:100, Biorbyt, Lielbritānija;

- BD4 - sc-59496, darba atšķaidījums 1:50, Santa Cruz Biotechnology, Inc., ASV.

Antivielu atšķaidīšanai lietoja antivielu atšķaidītāju (ab64211, Abcam, ASV). Pēc inkubācijas ar primārām antivielām paraugus skaloja ar TRIS bufera šḳīdumu 3 reizes pa 5 minūtēm, uz 10 minūtēm uzklāja HiDef Detection reakcijas amplifikatoru (954D-31, SigmaAldrich, ASV), vēlreiz skaloja ar TRIS bufera šḳīumu 3 reizes pa 5 minūtēm un uzklāja HiDef Detection HRP polimēra iez̄̄mētāju (954D-32, Sigma-Aldrich, ASV). Tālāk paraugus atkārtoti skaloja ar TRIS bufera šķīdumu un krāsoja ar hematoksilīnu (ab143166, Abcam, ASV) 10 min., lai vizualizētu šūnu kodolus. Pēc tam audus atkārtoti skaloja tekošā ūden̄̄, dehidratēja ar augošas koncentrācijas spirta šḳīdumu (spirts $70^{\circ}-3$ minūtes, spirts $96^{\circ}-2$ reizes pa 3 minūtēm), pārklāja ar karboksilolu 2 minūtes un ksilolu divas reizes pa 3 minūtēm. Tālāk preparātus fiksēja ar histolog̣isko līmi (00811, HistoLab, Zviedrija) un pārklāja ar segstikliņu. Audu griezumiem pagatavoja arī negatīvo kontroli, kur antivielas vietā izmantoja tikai antivielu atšķaidītāju. Visām izmantotajām antivielām pagatavoja pozitīvās kontroles, kur pētāmo audu 
vietā ņēma audus, kas vienmēr uzrāda pozitīvu reakciju. Visi preparāti tika izvērtēti Leica VM 6000B gaismas mikroskopā. Imūnhistoḳīmiski pozitīvo struktūru relatīvais daudzums tika izvērtēts ar puskvantitatīvo skaitīšanas metodi piecos nejauši izvēlētos redzes laukos katram audu griezumam (Pilmane, Rumba, Sundler, 1998). Imūnhistoḳīmiski pozitīvo struktūru relatīvā biežuma izvērtēšanas kritēriji attēloti 2.3. tabulā.

2.3. tabula

Imūnhistoḳīmiski pozitīvo struktūru relatīvā biežuma vērtēšanas kritēriji

\begin{tabular}{|c|l|}
\hline Apzīmējumi & \multicolumn{1}{c|}{ Skaidrojums } \\
\hline 0 & Redzes laukā netika konstatēta neviena pozitīva struktūra \\
\hline $0 /+$ & Redzes laukā retas pozit̄ivas struktūras \\
\hline+ & Redzes laukā maz pozitīvu struktūru \\
\hline$+/++$ & Redzes laukā maz līdz vidēji daudz pozit̄̄vu struktūru \\
\hline++ & Redzes laukā vidēji daudz pozitīvu struktūru \\
\hline$++/+++$ & Redzes laukā vidēji daudz līdz daudz pozitīvu struktūru \\
\hline+++ & Redzes laukā daudz pozitīvu struktūru \\
\hline+++++++ & Redzes laukā daudz līdz ḷoti daudz pozitīvu struktūru \\
\hline++++ & Redzes laukā ḷoti daudz pozitīvu struktūru \\
\hline
\end{tabular}

\subsection{TUNEL metode}

Programmētu šūnu nāvi jeb apoptozi noteica ar deoksinukleotidiltransferāzes dUTP iezīmētā gala marḳēšanu jeb TUNEL metodi (Negoescu et al., 1996). Krāsošanai pēc TUNEL metodes audus sagatavoja līdzīgi imūnhistoḳimijai - pēc rehidratācijas audus 10 minūtes skaloja destilētā ūden̄̄ un TRIS bufera šḳīdumā (15-M106, Bio-Optica, Itālija). Pēc tam audu paraugus apstrādāja ar $3 \%$ peroksīdu 10 minūtes, lai bloḳētu endogēno peroksidāzi, un atkārtoti skaloja ar TRIS bufera šķīdumu 3 reizes pa 5 minūtēm. Pēc tam 5 minūtes vārīja EDTA bufera šķīdumā (T0103, Diapath, Itālija), atdzesēja, atkārtoti skaloja TRIS bufera šḳīumā un atstāja $0,1 \%$ govs seruma albumīna fosfāta buferškīidumā. Tālāk audu paraugus $37{ }^{0} \mathrm{C}$ temperatūrā vienu stundu pārklāja ar TUNEL mix (11684817910, Roche Diagnostics, Vācija) enzīmu šķīdumu, pēc tam skaloja TRIS bufera šķīiumā 2 reizes pa 5 minūtēm un 30 minūtes $37{ }^{\circ} \mathrm{C}$ temperatūrā inkubēja ar mārrutku peroksidāzi saturošu reaǵentu. Pēc inkubācijas paraugus skaloja ar TRIS bufera šḳīdumu 3 reizes pa 5 minūtēm un uz 10 minūtēm pārklāja ar DAB šḳīdumu peroksidāzes noteikšanai. Tālāk paraugus atkārtoti skaloja ar TRIS bufera šķīdumu un krāsoja ar hematoksilīnu (ab143166, Abcam, ASV) 10 min., lai vizualizētu šūnu kodolus. Pēc tam audus atkārtoti skaloja tekošā ūdenī, dehidratēja ar augošas koncentrācijas spirta šķīdumu (spirts $70^{\circ}-3$ minūtes, spirts $96^{\circ}-2$ reizes pa 3 minūtēm), pārklāja ar 
karboksilolu 2 minūtes un ksilolu divas reizes pa 3 minūtēm. Tālāk preparātus fiksēja ar histoloǵgisko līmi (00811, HistoLab, Zviedrija) un pārklāja ar segstikliṇu.

Visi preparāti tika izvērtēti Leica VM 6000B gaismas mikroskopā. Trīs nejauši izvēlētos redzes laukos, kas nepārklājas, saskaitīja visus TUNEL pozitīvos kardiomiocītus, pēc tam noteica apoptotisko indeksu, kas ir apoptotisko kardiomiocītu skaits procentos no visiem kardiomiocītiem vienā redzes laukā (Soini, Paakko and Lehto, 1998).

\subsection{Datu statistiskā analīze}

Visas statistiskās analīzes tika veiktas, izmantojot IBM SPSS Statistics 22. Tā kā lielākā daḷa datu bija rangu skala, to apstrādei izmantojām neparametriskās statistikas metodes.

Lai noteiktu atšḳirības sadalījumā starp diviem dažādiem mainīgajiem, izmantojām Mann-Whitney U-testu (Hollander, Wolf and Chicken, 2014).

$$
U_{1}=R_{1}-\frac{n_{1}\left(n_{1}+1\right)}{2} \text { vai } U_{2}=R_{2}-\frac{n_{2}\left(n_{2}+1\right)}{2}
$$

$\mathrm{R}_{1}, \mathrm{R}_{2}$ - rangu summas katrā izlasē

$\mathrm{n}_{1}, \mathrm{n}_{2}-$ novērojumu skaits katrā izlasē

Lai pārbaudītu, vai nulles hipotēze ir spēkā, iegūto mazāko U vērtību salīdzina ar kritisko vērtību, ko atrod $\chi^{2}$ sadalījuma tabulās divām brīvības pakāpēm. Nulles hipotēzi noraida, ja U ir lielāks vai vienāds ar kritisko vērtību.

Lai noteiktu atšķirības starp trim un vairāk mainīgajiem, izmantojām Kruskal-Wallis H-testu (Teibe and Berkisis, 2001).

$$
H=\frac{12}{N(N+1)}\left(\frac{R_{X}^{2}}{n_{x}}+\frac{R_{y}^{2}}{n_{y}}+\frac{R_{z}^{2}}{n_{z}}\right)-3(N+1)
$$

$\mathrm{N}$ - kopējais novērojumu skaits

$\mathrm{n}_{\mathrm{x}}, \mathrm{n}_{\mathrm{y}}, \mathrm{n}_{\mathrm{z}}$ - novērojumu skaits katrā izlasē

$\mathrm{R}_{\mathrm{x}}, \mathrm{R}_{\mathrm{y}}, \mathrm{R}_{\mathrm{z}}$ - rangu summas katrā izlasē 
Lai pārbaudītu, vai nulles hipotēze ir spēkā, iegūto $H$ vērtību salīdzina ar kritisko vērtību, ko atrod $\chi^{2}$ sadalījuma tabulās divām brīvības pakāpēm. Nulles hipotēzi noraida, ja $\mathrm{H}$ ir lielāks vai vienāds ar kritisko vērtību.

Lai noteiktu sakarības starp mainīgajiem lielumiem, tika izmantota Spīrmana (Spearman) rangu secības korelācija (Teibe and Berḳis, 2001).

$$
r_{s}=1-\frac{6 \sum_{i=1}^{n} d_{i}^{2}}{n\left(n^{2}-1\right)}
$$

$\mathrm{r}_{\mathrm{s}}-$ Spīrmana rangu korelācijas koeficients

$\mathrm{d}_{\mathrm{i}}$ - rangu pāru starpība

$\mathrm{n}$ - novērojumu skaits

Aprēḳināto koeficientu interpretēja šādi: $r_{s}$ 0-0,3 vāja jeb maznozīmīga korelācija, $\mathrm{r}_{\mathrm{s}}$ 0,31-0,69 vidēji cieša korelācija, $\mathrm{r}_{\mathrm{s}}$ 0,7-0,99 cieša korelācija, 0 līdz $-0,3$ vāja jeb maznozīmīga negatīva korelācija, $r_{s}$ no $-0,31$ līdz $-0,69$ vidēji cieša negatīva korelācija, $\mathrm{r}_{\mathrm{s}}$ no $-0,7 \mathrm{l} \overline{\mathrm{d}} \mathrm{z}-0,99$ cieša negatīva korelācija.

Rezultātus uzskatîja par statistiski nozīmīgiem, ja p vērtība bija $<0,05$. 


\section{Rezultāti}

\subsection{Pārskata mikroskopija}

Gandrīz visos preparātos novēroja miokarda deǵenerāciju ar difūzu kardiomiocītu vakuolizāciju it īpaši zonās ap šūnas kodoliem (skatīt 1. attēlu pielikumā). Atsevišķos preparātos novēroja fokālu kardiomiocītu vakuolizāciju. Izteikta difūza vakuolizācija bija vairāk raksturīga pacientiem ar KSS - sešiem pacientiem (skatīt 2. attēlu pielikumā), bet pacientiem ar AoV stenozi kardiomiocītu vakuolizācija bija mērena - trīs pacientiem - vai maz izteikta - deviņiem pacientiem (skatīt 3. attēlu pielikumā). Diviem pacientiem ar KSS pārskata mikroskopijā kardiomiocītu vakuolizācija netika novērota vispār.

28 preparātos (18 preparātos pacientiem ar KSS (skatīit 4. attēlu pielikumā) un 10 preparātos pacientiem ar deǵeneratīvu AoV stenozi) novēroja dažādu izmēru kardiomiocītus un to kodolus, no tiem pieciem pacientiem ar KSS (skatît 5. attēlu pielikumā) un trim pacientiem ar AoV stenozi novēroja ḷoti lielus kardiomiocītu kodolus.

Trim pacientiem ar KSS un vienam pacientam ar deǵeneratīvu AoV stenozi novēroja nozīmīgu saistaudu ieaugšanu labā priekškambara miokardā (skatīt 6. attēlu pielikumā). Nozīmīgu asinsvadu sklerozi novēroja trim pacientiem ar deǵeneratīvu AoV (skatīt 7. attēlu pielikumā) un diviem pacientiem ar KSS (skatīt 8. attēlu pielikumā).

Lielā daḷā preparātu novēroja izmainītu epikarda un/vai endokarda epitēlija šūnu formu. Kubiskas formas epikarda epitēlija šūnas novēroja 17 pacientiem ar KSS (skatīt 9. attēlu pielikumā) un pieciem pacientiem ar deǵeneratīvu AoV stenozi (skatīt 10. attēlu pielikumā), bet plakanas formas epikarda epitēlija šūnas bija septiniem pacientiem ar KSS un sešiem pacientiem ar AoV stenozi. Kubiskas formas endokarda endotēlija šūnas novēroja 15 pacientiem ar KSS un septiniem pacientiem ar AoV stenozi, bet pārējiem pacientiem endokarda endotēlija šūnas bija plakanas formas (skatīt 11. attēlu pielikumā).

Atsevišķiem pacientiem novēroja fokālu iekaisuma šūnu infiltrāciju epikardā - trim pacientiem ar KSS (skatīt 12. attēlu pielikumā) un vienam pacientam ar deǵeneratīvu AoV stenozi (skatît 13. attēlu pielikumā).

\subsection{Apoptoze}

No 24 labā priekškambara audu paraugiem, kas ņemti no pacientiem ar KSS, tikai diviem netika konstatēti apoptotiski kardiomiocīti (skatīt 14. attēlu pielikumā); septiņos paraugos tādu bija vidēji daudz (++) (skatīt 15. attēlu pielikumā), deviṇos paraugos bija vidēji daudz līdz daudz (++/+++) un sešos paraugos bija daudz (+++) apoptotisku kardiomiocītu 
(skatīt 16. attēlu pielikumā). Apoptotiskais indekss pacientiem ar KSS bija 60,93 $\pm 21,68 \%$ un tas variēja no 0 līdz 83,82\%.

Pilnīgi visos labā priekškambara paraugos, kas ņemti no pacientiem ar deǵeneratīvu AoV stenozi, konstatēja vairāk vai mazāk izteiktu kardiomiocītu apoptozi. Maz līdz vidēji daudz $(+/++)$ apoptotisku kardiomiocītu konstatēja vienam pacientam ar deǵeneratīvu AoV stenozi, bet ḷoti daudz (++++) apoptotisku kardiomiocītu novēroja trim pacientiem (skatīt 17. attēlu pielikumā). Lielākajai daḷai - pieciem pacientiem ar AoV stenozi - labā priekškambara audos konstatēja vidēji daudz līdz daudz (++/+++) apoptotisku kardiomiocītu. Apoptotiskais indekss pacientiem ar deǵeneratīvu AoV stenozi bija 70,55 $\pm 15,51 \%$ un tas variēja no 36,00 līdz $87,50 \%$.

Salīdzinot apoptotisko kardiomiocītu daudzumu paraugos un apoptotisko indeksu pacientiem ar KSS un pacientiem ar deǵeneratīvu AoV stenozi, netika atrasta statistiski ticama atšķirība starp abām grupām (p 0,115 un p 0,136).

\subsection{PGP 9.5 saturoša inervācija}

Visās pētītajās grupās lielākajai daḷai pacientu labā priekškambara audos bija vismaz daudz līidz ḷoti daudz (+++/++++) PGP 9.5 saturošu nervu šķiedru (skatīt 18. attēlu pielikumā), attiecīgi KSS grupā 83,3 \% pacientu, AoV stenozes grupā $100 \%$ un kontroles grupā jeb pacientiem ar iedzimtām sirdskaitēm $80 \%$ pacientu. KSS pacientu grupā diviem pacientiem labā priekškambara audos bija maz līdz vidēji daudz (+/++) un vienam pacientam vidēji daudz (++) PGP 9.5 saturošu nervu šķiedru (skatît 3.1. tabulu). Visos preparātos vairāk PGP 9.5 saturošu nervu šķiedru novēroja zonās ap asinsvadiem (skatît 19. attēlu pielikumā).

Salīdzinot PGP 9.5 saturošo nervu šķiedru daudzumu labā priekškambara audos, starp trim pētāmajām grupām netika konstatēta statistiski ticami nozīmīga atšķirība (p 0,385). Nozīmīga atšķirība netika konstatēta arī starp pacientiem ar KSS un pacientiem ar deǵeneratīvu AoV stenozi (p 0,558). KSS grupā PGP 9.5 saturošu nervu šķiedru relatīvais daudzums uzrādīja vidēji ciešu negatīivu korelāciju ar labā kambara sistolisko spiedienu $\left(\mathrm{r}_{\mathrm{s}}-0,477 ; \mathrm{p} 0,018\right)$. 
PGP 9.5 saturošas inervācijas relatīvais daudzums labā priekškambara audos un tā statistiskais izvērtējums

\begin{tabular}{|c|c|c|c|}
\hline $\begin{array}{l}\text { Pozitīvo struktūru } \\
\text { relatīvais daudzums }\end{array}$ & $\begin{array}{c}\text { KSS } \\
\text { n (\%) } \\
24(100 \%)\end{array}$ & $\begin{array}{c}\text { AoV } \\
\text { n (\%) } \\
12(100 \%)\end{array}$ & $\begin{array}{c}\text { Kontroles grupa } \\
\text { n }(\%) \\
5(100 \%)\end{array}$ \\
\hline 0 & 0 & 0 & 0 \\
\hline $0 /+$ & 0 & 0 & 0 \\
\hline+ & 0 & 0 & 0 \\
\hline$+/++$ & $2(8,3 \%)$ & 0 & 0 \\
\hline++ & $1(4,2 \%)$ & 0 & 0 \\
\hline$++/+++$ & $1(4,2 \%)$ & 0 & $1(20,0 \%)$ \\
\hline+++ & $2(8,3 \%)$ & $3(25,0 \%)$ & 0 \\
\hline$+++/++++$ & $7(29,2 \%)$ & $6(50,0 \%)$ & 0 \\
\hline++++ & $11(45,8 \%)$ & $3(25,0 \%)$ & $4(80,0 \%)$ \\
\hline Mediāna & $+++/++++$ & $+++/++++$ & ++++ \\
\hline $\begin{array}{l}\text { Kruskal-Wallis } \\
\text { H-tests }\end{array}$ & & p 0,385 & \\
\hline $\begin{array}{l}\text { Mann-Whitney } \\
\text { U-tests }\end{array}$ & & 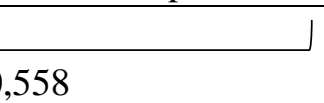 & \\
\hline
\end{tabular}

* Apzīmējumi: AoV - deǵeneratīva aortālā vārstuḷa stenozes grupa, KSS - koronāras sirds slimības grupa, PGP 9.5 - proteīna gēna produkts 9.5 .

Pozitīvo struktūru relatīvā daudzuma apzīmējumi: 0 redzes laukā netika konstatēta neviena pozitīva struktūra; 0/+ redzes laukā retas pozitīvas struktūras; + redzes laukā maz pozit̄ivu struktūru; +/++ redzes laukā maz līdz vidēji daudz pozitīvu struktūru; ++ redzes laukā vidēji daudz pozitīvu struktūru; ++/+++ redzes laukā vidēji daudz līdz daudz pozitīvu struktūru; +++ redzes laukā daudz pozitīvu struktūru; +++/+++++ redzes laukā daudz līdz loti daudz pozitīvu struktūru; ++++ redzes laukā ḷoti daudz pozitīvu struktūru.

\subsection{Audu faktori}

\subsection{1. Ātriju nātrijurētiskais peptīds (ANUP)}

Paraugos, kas tika ņemti gan no pacientiem ar KSS, gan no pacientiem ar deǵeneratīvu AoV stenozi, lielākajā dạ̣ā gadījumu novēroja daudz (+++) ANUP pozitīvu kardiomiocītu, attiecīgi 14 (skatīt 20. attēlu pielikumā) un sešiem (skatît 21. attēlu pielikumā) pacientiem (skatīt 3.2. tabulu). Trim pacientiem KSS grupā (skatīt 22. attēlu pielikumā) un vienam pacientam AoV stenozes grupā bija vidēji daudz (++) ANUP pozitīvu miokarda šūnu, septiniem pacientiem KSS grupā un četriem pacientiem AoV stenozes grupā vidēji daudz līdz daudz $(++/+++)$ pozitīivu kardiomocītu. AoV stenozes grupā bija viens pacients, kuram labā priekškambara audu paraugā konstatēja daudz līdz l,oti daudz $(+++/++++)$ ANUP pozitīvu kardiomiocītu. 
Kontroles grupā labā priekškambara audu paraugos, kas ņemti no pacientiem ar iedzimtām sirdskaitēm, kuri operēti agrīnā vecumā, novēroja šādu ANUP pozitīvo kardiomiocītu daudzumu - vienam pacientam bija maz $(+)$, vienam pacientam bija maz līdz vidēji daudz $(+/++)$, diviem pacientiem bija vidēji daudz $(++)$ un vienam pacientam bija daudz $(+++)$ ANUP pozitīvu kardiomiocītu.

Labā priekškambara audos tika konstatēta statistiski ticama atšksirība ANUP pozitīvu kardiomiocītu relatīvajā daudzumā starp visām trim grupām (p 0,029). Arī salīdzinot pacientus ar iegūtām sirdskaitēm un pacientus ar iedzimtām sirdskaitēm (kontroles grupa), tika konstatēta statistiski ticama atšķirība ANUP pozitīvo kardiomiocītu daudzumā (p 0,008), taču starp pacientiem ar KSS un pacientiem ar deǵeneratīvu AoV stenozi statistiski ticamu atšķirību nekonstatēja (p 0,721).

3.2. tabula

ANUP pozitīvo kardiomiocītu relatīvais daudzums labā priekškambara audos un tā statistiskais izvērtējums

\begin{tabular}{|c|c|c|c|}
\hline $\begin{array}{l}\text { Pozitīvo struktūru } \\
\text { relatīvais daudzums }\end{array}$ & $\begin{array}{c}\text { KSS } \\
\text { n (\%) } \\
24(100 \%) \\
\end{array}$ & $\begin{array}{c}\text { AoV } \\
\text { n (\%) } \\
12(100 \%) \\
\end{array}$ & $\begin{array}{c}\text { Kontroles grupa } \\
\text { n }(\%) \\
5(100 \%) \\
\end{array}$ \\
\hline 0 & 0 & 0 & 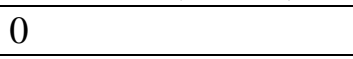 \\
\hline $0 /+$ & 0 & 0 & 0 \\
\hline+ & 0 & 0 & $1(20,0 \%)$ \\
\hline$+/++$ & 0 & 0 & $1(20,0 \%)$ \\
\hline++ & $3(12,5 \%)$ & $1(8,3 \%)$ & $2(40,0 \%)$ \\
\hline$++/+++$ & $7(29,2 \%)$ & $4(33,3 \%)$ & 0 \\
\hline+++ & $14(58,3 \%)$ & $6(50,0 \%)$ & $1(20,0 \%)$ \\
\hline$+++/++++$ & 0 & $1(8,3 \%)$ & 0 \\
\hline++++ & 0 & 0 & 0 \\
\hline Mediāna & +++ & +++ & ++ \\
\hline $\begin{array}{l}\text { Kruskal-Wallis } \\
\text { H-tests }\end{array}$ & \multicolumn{3}{|c|}{ p 0,029 } \\
\hline $\begin{array}{l}\text { Mann-Whitney } \\
\text { U-tests }\end{array}$ & & 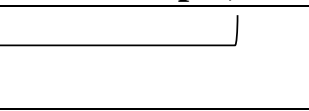 & \\
\hline
\end{tabular}

* Apzīmējumi: ANUP - ātriju nātrijurētiskais peptīds, AoV - deǵeneratīva aortālā vārstuḷa stenozes grupa, KSS - koronāras sirds slimības grupa.

Pozitīvo struktūru relatīvā daudzuma apzīmējumi: 0 redzes laukā netika konstatēta neviena pozitīva struktūra; 0/+ redzes laukā retas pozitīvas struktūras; + redzes laukā maz pozitīvu struktūru; +/++ redzes laukā maz līdz vidēji daudz pozitīvu struktūru; ++ redzes laukā vidēji daudz pozitīvu struktūru; ++/+++ redzes laukā vidēji daudz līdz daudz pozit̄ivu struktūru; +++ redzes laukā daudz pozitīvu struktūru; +++/++++ redzes laukā daudz līdz ḷoti daudz pozitīvu struktūru; ++++ redzes laukā loti daudz pozitīvu struktūru.

Jāatzīmē, ka ANUP pozitīvo struktūru daudzums KSS grupā uzrādīja vidēji ciešu pozitīvu korelāciju (skatît 3.3. tabulu) ar pacientu vecumu $\left(\mathrm{r}_{\mathrm{s}} 0,428 ; \mathrm{p} 0,037\right)$ un ciešu pozitīvu korelāciju ar BNP līmeni asinīs ( $\mathrm{r}_{\mathrm{s}}$ 0,867; p 0,002). 
ANUP pozitīvo kardiomiocītu relatīvā daudzuma korelācijas ar pacientu pirmsoperācijas klīniskajiem datiem

\begin{tabular}{|l|l|l|l|l|}
\hline Mark̦ieris1 & \multicolumn{1}{|c|}{ Grupa } & \multicolumn{1}{c|}{ Marḳieris2 } & \multicolumn{2}{c|}{$\mathbf{r}_{\mathrm{s}}$} \\
\hline \multirow{2}{*}{ ANUP } & \multirow{2}{*}{ KSS } & Vecums & 0,428 & 0,037 \\
\cline { 3 - 6 } & & BNP & 0,867 & 0,002 \\
\hline
\end{tabular}

* Apzīmējumi: ANUP - ātriju nātrijurētiskais peptīds, AoV - aortālā vārstuḷa stenoze, BNP - smadzeṇu nātrijurētiskais peptīds, KSS - koronāra sirds slimība, $\mathrm{r}_{\mathrm{s}}-$ Spīrmana rangu korelācijas koeficients.

\subsubsection{Asinsvadu endotēlija augšanas faktors (VEGF)}

VEGF pozitīvo endotēlija šūnu daudzums labā priekškambara asinsvados (skatīt 3.4. tabulu) pacientiem ar KSS variēja no to trūkuma (viens pacients) līdz ḷoti daudz (++++) pozitīvām šūnām redzes laukā (viens pacients), bet pacientiem ar AoV stenozi - no nevienas pozitīvas struktūras (viens pacients) līdz daudz līdz l,oti daudz pozitīvām struktūrām redzes laukā $(+++/++++)$ (viens pacients). Diviem pacientiem KSS grupā un vienam pacientam AoV stenozes grupā konstatēja retas (0/+) VEGF pozitīvas asinsvadu endotēlija šūnas redzes laukā, sešiem pacientiem KSS grupā un diviem AoV stenozes grupā bija maz (+) un pa četriem pacientiem katrā grupā bija vidēji daudz $(++)$ VEGF pozitīvu asinsvadu šūnu. Diviem pacientiem KSS grupā bija vidēji daudz līdz daudz (++/+++), sešiem pacientiem KSS grupā (skatīt 23. attēlu pielikumā) un trim pacientiem AoV stenozes grupā bija daudz (+++) VEGF pozitīvu asinsvadu endotēlija šūnu (skatīit 24. attēlu pielikumā).

Gan pacientiem ar KSS, gan ar AoV stenozi VEGF ekspresiju novēroja ne tikai labā priekškambara asinsvados, bet arī epikarda epitēlija (skatīi 25 . attēlu pielikumā) un endokarda endotēlija šūnās (skatīit 26. attēlu un 27. attēlu pielikumā). Tikai diviem pacientiem ar KSS un vienam pacientam ar AoV stenozi pētāmajos paraugos nebija VEGF pozitīvu šūnu ne epikardā, ne endokardā. 62,5 \% pacientu KSS grupā un 41,6 \% pacientu AoV stenozes grupā bija daudz līdz ļoti daudz (+++/++++) VEGF pozitīvu šūnu epikardā un endokardā.

Lai arī vizuāli KSS grupā VEGF pozitīvo endotēlija šūnu daudzums labā priekškambara asinsvados un endokardā vai epikardā bija lielāks nekā AoV stenozes grupā, statistiski ticamas atšḳirības starp šīm grupām netika konstatētas (p 0,745 un p 0,719).

Iedzimtu sirdskaišu grupā labā priekškambara asinsvados vienā paraugā bija retas (0/+) VEGF pozitīvas endotēlija šūnas, vienā paraugā bija maz (+) VEGF pozitīvu endotēlija šūnu, vienā paraugā bija vidēji daudz līdz daudz $(++/+++)$, bet divos paraugos bija ḷoti daudz $(++++)$ VEGF pozitīvu endoteliocītu (skatīt 3.4. tabulu). 
Salīdzinot VEGF pozitīvo šūnu relatīvo daudzumu labā priekškambara asinsvados visās trijās grupās, netika konstatēta statistiski ticama atšķirība (p 0,779); arī salīdzinot pacientus ar iegūtām sirdskaitēm un pacientus ar iedzimtām sirdskaitēm (kontroles grupa), tāda netika konstatēta (p 0,531). KSS grupā pacientiem ar kubiskas formas endokarda endotēlija šūnām bija pārliecinoši vairāk VEGF pozitīvo endokarda endotēlija šūnu nekā pacientiem, kam endokarda endotēlija šūnas bija plakanas (p 0,007). VEGF pozitīvo endokarda endotēlija šūnu relatīvais daudzums KSS grupā uzrādīja statistiski ticamu negatīvu vidēji ciešu korelāciju ar pulmonālas hipertensijas smaguma pakāpi $\left(\mathrm{r}_{\mathrm{s}}-0,429 ; \mathrm{p}\right.$ 0,036).

3.4. tabula

\section{VEGF pozitīvo struktūru relatīvais daudzums labā priekškambara audos un tā statistiskais izvērtējums}

\begin{tabular}{|c|c|c|c|c|c|}
\hline \multirow{2}{*}{$\begin{array}{c}\text { Pozitīvo } \\
\text { struktūru } \\
\text { relatīvais } \\
\text { daudzums }\end{array}$} & \multicolumn{3}{|c|}{ Asinsvadu endotēlijs } & \multicolumn{2}{|c|}{ Endokarda endotēlijs } \\
\hline & $\begin{array}{c}\text { KSS } \\
\text { n }(\%) \\
24(100 \%)\end{array}$ & $\begin{array}{c}\text { AoV } \\
\text { n (\%) } \\
12(100 \%)\end{array}$ & $\begin{array}{c}\text { Kontroles grupa } \\
\mathbf{n}(\%) \\
5(100 \%)\end{array}$ & $\begin{array}{c}\text { KSS } \\
\text { n (\%) } \\
24(100 \%)\end{array}$ & $\begin{array}{c}\text { AoV } \\
\text { n (\%) } \\
12(100 \%)\end{array}$ \\
\hline 0 & $1(4,2 \%)$ & $1(8,3 \%)$ & 0 & $2(8,3 \%)$ & $1(8,3 \%)$ \\
\hline $0 /+$ & $2(8,3 \%)$ & $1(8,3 \%)$ & $1(20,0 \%)$ & $4(16,7 \%)$ & 0 \\
\hline+ & $6(25,0 \%)$ & $2(16,7 \%)$ & $1(20,0 \%)$ & $2(8,3 \%)$ & $1(8,3 \%)$ \\
\hline$+/++$ & 0 & 0 & 0 & 0 & 0 \\
\hline++ & $4(16,7 \%)$ & $4(33,3 \%)$ & 0 & $1(4,2 \%)$ & $4(33,3 \%)$ \\
\hline$++/+++$ & $2(8,3 \%)$ & 0 & $1(20,0 \%)$ & 0 & $1(8,3 \%)$ \\
\hline+++ & $6(25,0 \%)$ & $3(25,0 \%)$ & 0 & $9(37,5 \%)$ & $3(25,0 \%)$ \\
\hline$+++/++++$ & $2(8,3 \%)$ & $1(8,3 \%)$ & 0 & $3(12,5 \%)$ & $1(8,3 \%)$ \\
\hline++++ & $1(4,2 \%)$ & 0 & $1(20,0 \%)$ & $3(12,5 \%)$ & $1(8,3 \%)$ \\
\hline Mediāna & ++ & ++ & $++/+++$ & +++ & $++\operatorname{li} \mathrm{dz}++/+++$ \\
\hline $\begin{array}{l}\text { Kruskal-Wallis } \\
\text { H-tests }\end{array}$ & \multicolumn{3}{|c|}{$L$} & \multicolumn{2}{|l|}{ - } \\
\hline $\begin{array}{l}\text { Mann-Whitney } \\
\text { U-tests }\end{array}$ & \multicolumn{3}{|c|}{ p 0,745} & \multicolumn{2}{|c|}{ p 0,719} \\
\hline
\end{tabular}

* Apzīmējumi: AoV - deǵeneratīva aortālā vārstuḷa stenozes grupa, KSS - koronāras sirds slimības grupa, VEGF asinsvadu endotēlija augšanas faktors.

Pozitīvo struktūru relatîvā daudzuma apzīmējumi: 0 redzes laukā netika konstatēta neviena pozitīva struktūra; 0/+ redzes laukā retas pozitīvas struktūras; + redzes laukā maz pozitīvu struktūru; +/++ redzes laukā maz līdz vidēji daudz pozitīvu struktūru; ++ redzes laukā vidēji daudz pozitîvu struktūru; ++/+++ redzes laukā vidēji daudz līdz daudz pozitīvu struktūru; +++ redzes laukā daudz pozitīvu struktūru; +++/++++ redzes laukā daudz līdz ḷoti daudz pozitīvu struktūru; ++++ redzes laukā ḷoti daudz pozitīvu struktūru.

\subsubsection{Hromogranīns A (ChgA)}

Abās iegūto sirdskaišu grupās ChgA pozitīvo endotēlija šūnu daudzums labā priekškambara asinsvados (skatīt 3.5. tabulu) variēja no nevienas pozitīivas šūnas redzes laukā (četriem pacientiem KSS grupā un diviem pacientiem AoV stenozes grupā) līdz daudz (+++) pozitīvām šūnām redzes laukā (trim pacientiem KSS grupā (skatīt 28. attēlu pielikumā) 
un vienam pacientam AoV stenozes grupā). Tomēr AoV stenozes grupā bija viens pacients, kura labā priekškambara asinsvados bija ḷoti daudz (++++) ChgA pozitīvu endotēlija šūnu.

3.5. tabula

\section{ChgA pozitīvo struktūru relatīvais daudzums labā priekškambara audos un tā statistiskais izvērtējums}

\begin{tabular}{|c|c|c|c|c|c|}
\hline \multirow{2}{*}{$\begin{array}{l}\text { Pozitīvo } \\
\text { struktūru } \\
\text { relatīvais } \\
\text { daudzums }\end{array}$} & \multicolumn{3}{|c|}{ Asinsvadu endotēlijs } & \multicolumn{2}{|c|}{ Endokarda endotēlijs } \\
\hline & $\begin{array}{c}\text { KSS } \\
\text { n }(\%) \\
24(100 \%)\end{array}$ & $\begin{array}{c}\text { AoV } \\
\text { n }(\%) \\
12(100 \%)\end{array}$ & $\begin{array}{c}\text { Kontroles grupa } \\
\text { n }(\%) \\
5(100 \%)\end{array}$ & $\begin{array}{c}\text { KSS } \\
\text { n }(\%) \\
24(100 \%)\end{array}$ & $\begin{array}{c}\text { AoV } \\
\text { n }(\%) \\
12(100 \%)\end{array}$ \\
\hline 0 & $4(16,7 \%)$ & $2(16,7 \%)$ & 0 & $3(12,5 \%)$ & $1(8,3 \%)$ \\
\hline $0 /+$ & $2(8,3 \%)$ & 0 & 0 & 0 & $1(8,3 \%)$ \\
\hline+ & $4(16,7 \%)$ & $1(8,3 \%)$ & 0 & $2(8,3 \%)$ & $1(8,3 \%)$ \\
\hline$+/++$ & $3(12,5 \%)$ & $4(33,3 \%)$ & 0 & 0 & 0 \\
\hline++ & $4(16,7 \%)$ & $1(8,3 \%)$ & 0 & $3(12,5 \%)$ & $1(8,3 \%)$ \\
\hline$++/+++$ & $4(16,7 \%)$ & $2(16,7 \%)$ & $1(20,0 \%)$ & $6(25,0 \%)$ & $1(8,3 \%)$ \\
\hline+++ & $3(12,5 \%)$ & $1(8,3 \%)$ & $4(80,0 \%)$ & $8(33,3 \%)$ & $7(58,3 \%)$ \\
\hline$+++/++++$ & 0 & 0 & \begin{tabular}{|l|}
0 \\
\end{tabular} & $2(8,3 \%)$ & 0 \\
\hline++++ & 0 & $1(8,3 \%)$ & 0 & 0 & 0 \\
\hline Mediāna & $+/++$ & $+/++$ & +++ & $++/+++$ & +++ \\
\hline $\begin{array}{l}\text { Kruskal-Wallis } \\
\text { H-tests }\end{array}$ & \multicolumn{3}{|c|}{ L } & \\
\hline $\begin{array}{l}\text { Mann-Whitney } \\
\text { U-tests }\end{array}$ & \multicolumn{3}{|c|}{ p 0,647} & \multicolumn{2}{|c|}{ p 0,779} \\
\hline
\end{tabular}

* Apzīmējumi: AoV - deǵeneratīva aortālā vārstuḷa stenozes grupa, ChgA - hromogranīns A, KSS - koronāras sirds slimības grupa.

Pozitīvo struktūru relatīvā daudzuma apzīmējumi: 0 redzes laukā netika konstatēta neviena pozitīva struktūra; 0/+ redzes laukā retas pozitīvas struktūras; + redzes laukā maz pozitīvu struktūru; +/++ redzes laukā maz līdz vidēji daudz pozitīvu struktūru; ++ redzes laukā vidēji daudz pozitīvu struktūru; ++/+++ redzes laukā vidēji daudz līdz daudz pozitīvu struktūru; +++ redzes laukā daudz pozitīvu struktūru; +++/++++ redzes laukā daudz līdz ḷoti daudz pozitīvu struktūru; ++++ redzes laukā ḷoti daudz pozitīvu struktūru.

Lielai daļai iegūto sirdskaišu pacientu novēroja ChgA ekspresiju arī labā priekškambara endokarda endotēlija (skatīt 29. attēlu pielikumā) un epikarda epitēlija šūnās (skatīt 30. attēlu pielikumā). KSS grupā diviem pacientiem bija maz (+), trim pacientiem bija vidēji daudz $(++)$, sešiem pacientiem bija vidēji daudz līdz daudz $(++/+++)$, astoṇiem pacientiem daudz $(+++)$ un diviem pacientiem daudz līdz ḷoti daudz $(+++/++++)$ pozitīvu endokarda vai epikarda epitēlija šūnu. AoV stenozes grupā vienam pacientam atradām retas pozitīvas šūnas redzes laukā $(0 /+)$, vienam pacientam maz $(+)$, vienam pacientam vidēji daudz $(++)$, vienam pacientam vidēji daudz līdz daudz $(++/+++)$ un septiņiem pacientiem daudz $(+++)$ pozitīivu endokarda vai epikarda šūnu (skatīt 31 . attēlu pielikumā) redzes laukā.

Savukārt kontroles grupā jeb pacientiem ar iedzimtām sirdskaitēm ChgA pozitīvo endotēlija šūnu daudzums labā priekškambara asinsvados (skatīt 3.5. tabulu) variēja no vidēji daudz (++) vienam pacientam līdz daudz $(+++)$ ChgA pozitīvu struktūru redzes laukā četriem 
pacientiem. Turklāt ChgA pozitīvo asinsvadu endotēlija šūnu relatīvais daudzums bija statistiski nozīmīgi atšḳirīgs starp visām trim pētījumā iesaistītajām grupām (p 0,017).

\subsubsection{Endotelīns 1 (ET-1)}

Lielākajai daḷai pacientu ar iegūtām sirdskaitēm (37,5 \% KSS grupā un 33,3 \% AoV stenozes grupā) bija vidēji daudz (++) ET-1 pozitīvu endotēlija šūnu labā priekškambara asinsvados (skatīt 3.6. tabulu). KSS grupā ET-1 pozitīvu endotēlija šūnu daudzums labā priekškambara asinsvados variēja no to trūkuma diviem pacientiem līdz daudz pozitīvām struktūrām redzes laukā $(+++)$ arī diviem pacientiem (skatīt 32. attēlu pielikumā), bet deǵeneratīvas AoV stenozes grupā no nevienas pozitīvas šūnas redzes laukā vienam pacientam līdz daudz līdz ḷoti daudz (+++/++++) ET-1 pozitīvu struktūru redzes laukā diviem pacientiem (skatīt 33. attēlu pielikumā). Iedzimtu sirdskaišu jeb kontroles grupā lielākajā daḷā preparātu $(60 \%)$ bija atrodamas vien retas (0/+) ET-1 pozitīvas endotēlija šūnas asinsvados, vienā preparātā ET-1 pozitīvas endotēlija šunas asinsvados netika konstatētas nemaz, un vienā preparātā bija vidēji daudz (++) ET-1 pozitīvu endotēlija šūnu asinsvados. Statistiski ticamu atšķirību ET-1 pozitīvu asinsvadu endotēlija šūnu relatīvajā daudzumā nekonstatēja ne starp visām trim pētījumā apskatītajām grupām (p 0,109), ne arī atsevišķi starp pacientiem ar KSS un pacientiem ar deǵeneratīvu AoV stenozi (p 0,666). Apskatot kopā pacientus ar iegūtām sirdskaitēm, ET-1 pozitīvo endotēlija šūnu relatīvais daudzums labā priekškambara asinsvados uzrādīja vāju negatīvu korelāciju ar labā kambara sistolisko spiedienu ( $\mathrm{r}_{\mathrm{s}}-0,345 ; \mathrm{p}$ 0,039).

Gandrīz visos paraugos, izṇemot vienu labā priekškambara paraugu, kas ņemts no pacienta ar deǵeneratīvu AoV stenozi, konstatēja ET-1 pozitīvas endokarda endotēlija šūnas (skatīt 3.6. tabulu). ET-1 ekspresiju endokardā konstatēja gan vietās ar plakanām endotēlija šūnām (skatīt 34. attēlu pielikumā), gan vietās ar kubiskas formas endotēlija šūnām (skatīt 35. attēlu pielikumā). Lai arī ET-1 pozitīvo endokarda endotēlija šūnu relatīvā daudzuma mediāna KSS grupā bija vidēji daudz līdz daudz $(++/+++)$, bet deǵeneratīvas AoV stenozes grupā vidēji daudz (++), statistiski ticamu atšķirību starp šīm grupām nekonstatējām (p 0,174). Pacientiem ar AoV stenozi, kas pastāvīgi lietoja statīnus, bija statistiski ticami mazāk ET-1 pozitīvu endotēlija šūnu labā priekškambara endokardā nekā pacientiem, kas statīnus nelietoja (p 0,047). 
ET-1 pozitīvo struktūru relatīvais daudzums labā priekškambara audos un tā statistiskais izvērtējums

\begin{tabular}{|c|c|c|c|c|c|}
\hline \multirow{2}{*}{$\begin{array}{l}\text { Pozitīvo } \\
\text { struktūru } \\
\text { relatīvais } \\
\text { daudzums }\end{array}$} & \multicolumn{3}{|c|}{ Asinsvadu endotēlijs } & \multicolumn{2}{|c|}{ Endokarda endotēlijs } \\
\hline & $\begin{array}{c}\text { KSS } \\
\text { n (\%) } \\
24(100 \%)\end{array}$ & $\begin{array}{c}\text { AoV } \\
\text { n }(\%) \\
12(100 \%)\end{array}$ & $\begin{array}{c}\text { Kontroles grupa } \\
\mathbf{n}(\%) \\
\mathbf{5}(\mathbf{1 0 0} \%)\end{array}$ & $\begin{array}{c}\text { KSS } \\
\text { n (\%) } \\
24(100 \%)\end{array}$ & $\begin{array}{c}\text { AoV } \\
\text { n }(\%) \\
12(100 \%)\end{array}$ \\
\hline 0 & $2(8,3 \%)$ & $1(8,3 \%)$ & $1(20,0 \%)$ & 0 & $1(8,3 \%)$ \\
\hline $0 /+$ & $3(12,5 \%)$ & $2(16,7 \%)$ & $3(60,0 \%)$ & $1(4,2 \%)$ & $1(8,3 \%)$ \\
\hline+ & $3(12,5 \%)$ & $2(16,7 \%)$ & 0 & $1(4,2 \%)$ & $1(8,3 \%)$ \\
\hline$+/++$ & $1(4,2 \%)$ & $1(8,3 \%)$ & 0 & 0 & $1(8,3 \%)$ \\
\hline++ & $9(37,5 \%)$ & $4(33,3 \%)$ & $1(20,0 \%)$ & $8(33,3 \%)$ & $3(25,0 \%)$ \\
\hline$++/+++$ & $4(16,7 \%)$ & 0 & 0 & $4(16,7 \%)$ & $1(8,3 \%)$ \\
\hline+++ & $2(8,3 \%)$ & 0 & 0 & $9(37,5 \%)$ & $2(16,7 \%)$ \\
\hline$+++/++++$ & 0 & $2(16,7 \%)$ & 0 & $1(4,2 \%)$ & 0 \\
\hline++++ & 0 & 0 & 0 & 0 & $1(8,3 \%)$ \\
\hline Mediāna & ++ & $+/++$ lī $\mathrm{dz}++$ & $0 /+$ & $++/+++$ & ++ \\
\hline $\begin{array}{l}\text { Kruskal-Wallis } \\
\text { H-tests }\end{array}$ & \multicolumn{3}{|c|}{ L } & \multicolumn{2}{|l|}{-} \\
\hline $\begin{array}{l}\text { Mann-Whitney } \\
\text { U-tests }\end{array}$ & \multicolumn{3}{|c|}{ p 0,666} & \multicolumn{2}{|c|}{ p 0,174} \\
\hline
\end{tabular}

* Apzīmējumi: AoV - deǵeneratīva aortālā vārstuḷa stenozes grupa, KSS - koronāras sirds slimības grupa, ET- 1 - endotelīns 1.

Pozitīvo struktūru relatīvā daudzuma apzīmējumi: 0 redzes laukā netika konstatēta neviena pozitīva struktūra; 0/+ redzes laukā retas pozitīvas struktūras; + redzes laukā maz pozitīvu struktūru; +/++ redzes laukā maz līdz vidēji daudz pozit̄̄vu struktūru; ++ redzes laukā vidēji daudz pozit̄̄vu struktūru; ++/+++ redzes laukā vidēji daudz līdz daudz pozitīvu struktūru; +++ redzes laukā daudz pozitīvu struktūru; +++/++++ redzes laukā daudz līdz loti daudz pozitīvu struktūru; ++++ redzes laukā loti daudz pozit̄ivu struktūru.

\subsection{Iekaisuma faktori}

\subsubsection{Interleikīns $1 \alpha(\mathrm{Il}-1 \alpha)$}

Pētījumā iekḷautajos audu paraugos Il-1 $\alpha$ pozitīvas bija galvenokārt saistaudu un endokarda endotēlija (skatīt 3.7. tabulu) vai epikarda epitēlija šūnas (skatīt 36. attēlu pielikumā). Deviņiem pacientiem KSS grupā un četriem pacientiem deǵeneratīvas AoV stenozes grupā nebija Il-1 $\alpha$ pozitīvu saistaudu šūnu labā priekškambara audos, deviniiem

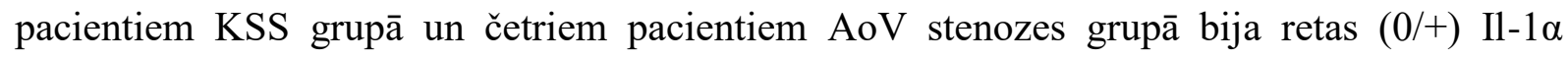
pozitīvas saistaudu šūnas, pieciem pacientiem KSS un trim pacientiem AoV stenozes grupā bija maz (+) Il-1 $\alpha$ pozitīvu saistaudu šūnu, bet vienam pacientam KSS grupā bija maz līdz vidēji daudz (+/++) Il-1 $\alpha$ pozitīvu saistaudu šūnu (skatīit 37. attēlu pielikumā) un vienam pacientam AoV stenozes grupā bija vidēji daudz līdz daudz (++/+++) Il-1 $\alpha$ pozitīivu saistaudu šūnu. Arī kontroles audos Il-1 $\alpha$ pozitīvu saistaudu šūnu bija samērā maz - diviem pacientiem netika konstatētas Il-1 $\alpha$ pozitīvas saistaudu šūnas, diviem pacientiem bija retas (0/+) Il-1 $\alpha$ pozitīvas saistaudu šūnas un tikai vienam pacientam konstatēja vidēji daudz (++) Il-1 $\alpha$ pozitīvu saistaudu 
šūnu. Il-1 $\alpha$ pozitīvo saistaudu šūnu relatīvā daudzuma mediāna visās trijās grupās bija retas pozitīvas struktūras redzes laukā $(0 /+)$, un netika konstatēta statistiski ticama atškikirība starp visām pētījumā apskatītajām grupām (p 0,883).

3.7. tabula

\section{Il-1 $\alpha$ pozitīvo struktūru relatīvais daudzums labā priekškambara audos un tā statistiskais izvērtējums}

\begin{tabular}{|c|c|c|c|c|c|}
\hline \multirow{2}{*}{$\begin{array}{l}\text { Pozitīvo } \\
\text { struktūru } \\
\text { relatīvais } \\
\text { daudzums }\end{array}$} & \multicolumn{3}{|c|}{ Saistaudi } & \multicolumn{2}{|c|}{ Endokarda endotēlijis } \\
\hline & $\begin{array}{c}\text { KSS } \\
\text { n (\%) } \\
24(100 \%)\end{array}$ & $\begin{array}{c}\text { AoV } \\
\text { n (\%) } \\
12(100 \%)\end{array}$ & $\begin{array}{c}\text { Kontroles grupa } \\
\text { n }(\%) \\
\mathbf{5}(\mathbf{1 0 0} \%) \\
\end{array}$ & $\begin{array}{c}\text { KSS } \\
\text { n }(\%) \\
24(100 \%)\end{array}$ & $\begin{array}{c}\text { AoV } \\
\text { n (\%) } \\
12(100 \%)\end{array}$ \\
\hline 0 & $9(37,5 \%)$ & $4(33,3 \%)$ & $2(40,0 \%)$ & $7(29,2 \%)$ & $4(33,3 \%)$ \\
\hline $0 /+$ & $9(37,5 \%)$ & $4(33,3 \%)$ & $2(40,0 \%)$ & $4(16,7 \%)$ & $1(8,3 \%)$ \\
\hline+ & $5(20,8 \%)$ & $3(25,0 \%)$ & 0 & 0 & $4(33,3 \%)$ \\
\hline$+/++$ & $1(4,2 \%)$ & 0 & 0 & $5(20,8 \%)$ & $1(8,3 \%)$ \\
\hline++ & 0 & 0 & $1(20,00 \%)$ & $5(20,8 \%)$ & $1(8,3 \%)$ \\
\hline$++/+++$ & 0 & $1(8,3 \%)$ & 0 & $2(8,3 \%)$ & 0 \\
\hline+++ & 0 & 0 & 0 & $1(4,2 \%)$ & $1(8,3 \%)$ \\
\hline$+++/++++$ & 0 & 0 & 0 & 0 & 0 \\
\hline++++ & 0 & 0 & 0 & 0 & 0 \\
\hline Mediāna & $0 /+$ & $0 /+$ & $0 /+$ & $+/++$ & + \\
\hline $\begin{array}{l}\text { Kruskal-Wallis } \\
\text { H-tests }\end{array}$ & \multicolumn{3}{|c|}{ L } & \multicolumn{2}{|l|}{ 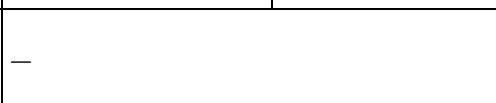 } \\
\hline $\begin{array}{l}\text { Mann-Whitney } \\
\text { U-tests }\end{array}$ & \multicolumn{3}{|c|}{ p 0,632} & \multicolumn{2}{|c|}{ p 0,461} \\
\hline
\end{tabular}

* Apzīmējumi: AoV - deǵeneratīva aortālā vārstuḷa stenozes grupa, Il-1 $\alpha$ - interleikīns $1 \alpha, \mathrm{KSS}$ - koronāras sirds slimības grupa.

Pozitīvo struktūru relatīvā daudzuma apzīmējumi: 0 redzes laukā netika konstatēta neviena pozitīva struktūra; 0/+ redzes laukā retas pozitīvas struktūras; + redzes laukā maz pozitīvu struktūru; +/++ redzes laukā maz līdz vidēji daudz pozitīvu struktūru; ++ redzes laukā vidēji daudz pozitīvu struktūru; ++/+++ redzes laukā vidēji daudz līdz daudz pozitīvu struktūru; +++ redzes laukā daudz pozitīvu struktūru; +++/++++ redzes laukā daudz līdz loti daudz pozitīvu struktūru; ++++ redzes laukā ḷoti daudz pozitīvu struktūru.

Il-1 $\alpha$ pozitīvu endokarda endotēlija šūnu daudzums abās iegūto sirdskaišu grupās variēja no to trūkuma (KSS grupā 29,2 \%, AoV stenozes grupā 33,3 \% (skatīit 38. attēlu pielikumā) līdz daudz (+++) pozitīvām struktūrām redzes laukā (KSS grupā 4,2 \%, AoV stenozes grupā 8,3 \%) un statistiski neatšḳīāās starp abām grupām (p 0,461). AoV stenozes grupā Il-1 $\alpha$ pozitīvo endokarda endotēlija šūnu relatīvais daudzums uzrādīja vidēji ciešu negatīvu korelāciju ar labā kambara sistolisko spiedienu $\left(\mathrm{r}_{\mathrm{s}}-0,606 ; \mathrm{p}\right.$ 0,037). 


\subsubsection{Interleikīns 10 (Il-10)}

Pretiekaisuma citokīna Il-10 ekspresija bija vērojama visās labā priekškambara audu paraugos esošajās audu grupās (skatīt 3.8. un 3.9. tabulu) - kardiomiocītos, saistaudos, asinsvadu un endokarda endotēlijā, kā arī epikarda epitēlijā (skatīt 39. attēlu pielikumā). No 24 labā priekškambara audu paraugiem, kas ņemti no pacientiem ar KSS, 10 paraugos bija vidēji daudz līdz daudz (++/+++) Il-10 pozitīvu kardiomiocītu un 12 paraugos daudz $(+++)$ Il- 10 pozitīvu kardiomiocītu (skatīt 40. attēlu pielikumā), bet vienam pacientam maz līdz vidēji daudz $(+/++)$ un vienam pacientam vidēji daudz (++) Il-10 pozitīvu kardiomiocītu (skatīt 41. attēlu pielikumā). Turklāt Il-10 pozitīvo kardiomiocītu relatīvais daudzums uzrādīja vidēji ciešu pozitīvu korelāciju ar pacientu vecumu $\left(\mathrm{r}_{\mathrm{s}} 0,596 ; \mathrm{p} 0,002\right)$ (skatīt 3.10. tabulu). Šīs pašas grupas pacientiem Il-10 ekspresija saistaudu šūnās bija mazāka nekā kardiomiocītos un variēja no retām (0/+) Il-10 pozitīvām saistaudu šūnām redzes laukā četriem pacientiem līdz daudz $(+++)$ pozitīvām saistaudu šūnām redzes laukā pieciem pacientiem. Il-10 pozitīvu saistaudu šūnu relatīvā daudzuma mediāna bija vidēji daudz (++). Il-10 ekspresija bija vērojama arī labā priekškambara asinsvadu un endokarda endotēlijā. KSS grupā tikai vienam pacientam netika konstatētas Il-10 pozitīvas endotēlija šūnas labā priekškambara asinsvados, bet vienam pacientam bija maz (+), trim pacientiem maz līdz vidēji daudz $(+/++)$, septiņiem pacientiem vidēji daudz (++) (skatīt 42. attēlu pielikumā), četriem pacientiem vidēji daudz līdz daudz $(++/+++)$, sešiem pacientiem daudz $(+++)$, vienam pacientam daudz līdz loti daudz $(+++/++++)$ un vienam pacientam bija ḷoti daudz $(++++)$ pozitīvu asinsvadu endotēlija šūnu. Turklāt pacientiem ar KSS un CRO asin̄̄s, lielāku par $5 \mathrm{mg} / \mathrm{L}$, bija statistiski ticami mazāk Il-10 pozitīvu endotēlija šūnu labā priekškambara asinsvados (p 0,018). Lielākajai daliai pacientu $(66,7 \%)$ ar KSS bija daudz (+++) Il-10 pozitīvu endokarda endotēlija šūnu labā priekškambara audos (skatīt 43. attēlu pielikumā) un to relatīvais daudzums uzrādīja vidēji ciešu negatīvu korelāciju ar kreisā kambara izsviedes frakciju $\left(r_{s}-0.441 ; p 0,031\right)$ (skatìt 3.10. tabulu).

AoV stenozes grupā lielākajai daḷai pacientu (58,3 \%) labā priekškambara audos bija vidēji daudz līdz daudz (++/+++) Il-10 pozitīvu kardiomiocītu (skatīt 44. attēlu pielikumā), bet Il-10 pozitīvo saistaudu šūnu daudzums variēja no retām pozitīvām šūnām redzes laukā $(0 /+)$ 16,7 \% līdz daudz pozitīvām šūnām redzes laukā (+++) 20,8 \% un Il-10 pozitīvo saistaudu šūnu relatîvā daudzuma mediāna bija vidēji daudz (++). Šajā pašā grupā no 12 paraugiem divos bija maz līdz vidēji daudz (+/++), piecos vidēji daudz (++), vienā - vidēji daudz līdz daudz $(++/+++)$ un četros daudz $(+++)$ Il-10 pozitīvu asinsvadu endotēlija šūnu (skatīt 45 . attēlu 
pielikumā). 91,7 \% pacientu AoV stenozes grupā labā priekškambara audos bija vismaz vidēji daudz (++) Il-10 pozitīvu endokarda endotēlija šūnu (skatīt 46. attēlu pielikumā).

3.8. tabula

Il-10 pozitīvo kardiomiocītu un saistaudu šūnu relatīvais daudzums labā priekškambara audos un tā statistiskais izvērtējums

\begin{tabular}{|c|c|c|c|c|c|c|}
\hline \multirow[b]{2}{*}{$\begin{array}{l}\text { Pozitīivo } \\
\text { struktūru } \\
\text { relatīvais } \\
\text { daudzums }\end{array}$} & \multicolumn{3}{|c|}{ Kardiomiocīti } & \multicolumn{3}{|c|}{ Saistaudu šūnas } \\
\hline & $\begin{array}{c}\text { KSS } \\
\text { n }(\%) \\
24(100 \%)\end{array}$ & $\begin{array}{c}\text { AoV } \\
\text { n }(\%) \\
12(100 \%)\end{array}$ & $\begin{array}{l}\text { Kontroles } \\
\text { grupa } \\
\text { n }(\%) \\
5(100 \%)\end{array}$ & $\begin{array}{c}\text { KSS } \\
\text { n }(\%) \\
24(100 \%)\end{array}$ & $\begin{array}{c}\text { AoV } \\
\text { n }(\%) \\
12(100 \%)\end{array}$ & $\begin{array}{l}\text { Kontroles } \\
\text { grupa } \\
\text { n }(\%) \\
5(100 \%)\end{array}$ \\
\hline 0 & 0 & 0 & 0 & 0 & 0 & 0 \\
\hline $0 /+$ & 0 & 0 & 0 & $4(16,7 \%)$ & $3(25,0 \%)$ & $4(80,0 \%)$ \\
\hline+ & 0 & 0 & 0 & $2(8,3 \%)$ & $1(8,3 \%)$ & 0 \\
\hline$+/++$ & $1(4,2 \%)$ & 0 & 0 & $3(12,5 \%)$ & $3(25,0 \%)$ & 0 \\
\hline++ & $1(4,2 \%)$ & $4(33,3 \%)$ & $2(40,0 \%)$ & $6(25,0 \%)$ & $2(16,7 \%)$ & $1(20,0 \%)$ \\
\hline$++/+++$ & $10(41,7 \%)$ & $7(58,3 \%)$ & $3(60,0 \%)$ & $4(16,7 \%)$ & $2(16,7 \%)$ & 0 \\
\hline+++ & $12(50,0 \%)$ & $1(8,3 \%)$ & 0 & $5(20,8 \%)$ & $1(8,3 \%)$ & 0 \\
\hline$+++/++++$ & 0 & 0 & 0 & 0 & 0 & 0 \\
\hline++++ & 0 & 0 & 0 & 0 & 0 & 0 \\
\hline Mediāna & $\begin{array}{c}++/+++ \text { lī } \mathrm{dz} \\
+++\end{array}$ & $++/+++$ & ++/+++ & ++ & +/++ & $0 /+$ \\
\hline $\begin{array}{l}\text { Kruskal- } \\
\text { Wallis } \\
\text { H-tests }\end{array}$ & \multicolumn{3}{|c|}{ p } & \multicolumn{3}{|c|}{ L } \\
\hline $\begin{array}{l}\text { Mann- } \\
\text { Whitney } \\
\text { U-tests }\end{array}$ & \multicolumn{3}{|c|}{ p 0,010 } & \multicolumn{3}{|c|}{ p 0,290} \\
\hline
\end{tabular}

* Apzīmējumi: AoV - deǵeneratīva aortālā vārstuḷa stenozes grupa, Il-10 - interleikīns 10, KSS - koronāras sirds slimības grupa.

Pozitīvo struktūru relatīvā daudzuma apzīmējumi: 0 redzes laukā netika konstatēta neviena pozitīva struktūra; 0/+ redzes laukā retas pozit̄ivas struktūras; + redzes laukā maz pozitīvu struktūru; +/++ redzes laukā maz līdz vidēji daudz pozitīvu struktūru; ++ redzes laukā vidēji daudz pozitīvu struktūru; ++/+++ redzes laukā vidēji daudz līdz daudz pozitīvu struktūru; +++ redzes laukā daudz pozitīvu struktūru; +++/++++ redzes laukā daudz līdz ḷoti daudz pozitīvu struktūru; ++++ redzes laukā ḷoti daudz pozit̄̄vu struktūru.

Iedzimtu sirdskaišu (kontroles) grupā diviem pacientiem bija vidēji daudz (++) un trim pacientiem vidēji daudz līdz daudz (++/+++) Il-10 pozitīvu kardiomiocītu (skatīt 47. attēlu pielikumā), bet $80 \%$ paraugu konstatēja retas (0/+) Il-10 pozitīvas saistaudu šūnas. Salīdzinoši maz Il-10 pozitīvu endotēlija šūnu kontroles grupas pacientiem bija arī labā priekškambara asinsvados un endokardā. $40 \%$ pacientu bija maz (+) un $60 \%$ retas (0/+) Il-10 pozitīvas asinsvadu endotēlija šūnas. Diviem pacientiem netika konstatētas Il-10 pozitīvas endokarda endotēlija šūnas labā priekškambara audu paraugos. 
Il-10 pozitīvo asinsvadu un endokarda endotēlija šūnu relatīvais daudzums labā priekškambara audos un tā statistiskais izvērtējums

\begin{tabular}{|c|c|c|c|c|c|c|}
\hline \multirow[b]{2}{*}{$\begin{array}{l}\text { Pozitīivo } \\
\text { struktūru } \\
\text { relatīvais } \\
\text { daudzums }\end{array}$} & \multicolumn{3}{|c|}{ Asinsvadu endotēlijs } & \multicolumn{3}{|c|}{ Endokarda endotēlijs } \\
\hline & $\begin{array}{c}\text { KSS } \\
\text { n (\%) } \\
24(100 \%)\end{array}$ & $\begin{array}{c}\text { AoV } \\
\text { n (\%) } \\
12(100 \%)\end{array}$ & $\begin{array}{l}\text { Kontroles } \\
\text { grupa } \\
\text { n }(\%) \\
5(100 \%) \\
\end{array}$ & $\begin{array}{c}\text { KSS } \\
\text { n }(\%) \\
24(100 \%)\end{array}$ & $\begin{array}{c}\text { AoV } \\
\text { n (\%) } \\
12(100 \%)\end{array}$ & $\begin{array}{l}\text { Kontroles } \\
\text { grupa } \\
\text { n }(\%) \\
\mathbf{5}(\mathbf{1 0 0 \%} \%) \\
\end{array}$ \\
\hline 0 & $1(4,2 \%)$ & 0 & 0 & 0 & 0 & $2(40,0 \%)$ \\
\hline $0 /+$ & 0 & 0 & $3(60,0 \%)$ & $2(8,3 \%)$ & $1(8,3 \%)$ & $1(20,0 \%)$ \\
\hline+ & $1(4,2 \%)$ & 0 & $2(40,0 \%)$ & 0 & 0 & $2(40,0 \%)$ \\
\hline$+/++$ & $3(12,5 \%)$ & $2(16,7 \%)$ & 0 & $1(4,2 \%)$ & 0 & 0 \\
\hline++ & $7(29,2 \%)$ & $5(41,7 \%)$ & 0 & 0 & $3(25,0 \%)$ & 0 \\
\hline$++/+++$ & $4(16,7 \%)$ & $1(8,3 \%)$ & 0 & $1(4,2 \%)$ & $3(25,0 \%)$ & 0 \\
\hline+++ & $6(25,0 \%)$ & $4(33,3 \%)$ & 0 & $16(66,7 \%)$ & $5(41,7 \%)$ & 0 \\
\hline$+++/++++$ & $1(4,2 \%)$ & 0 & 0 & $3(12,5 \%)$ & 0 & 0 \\
\hline++++ & $1(4,2 \%)$ & 0 & 0 & $1(4,2 \%)$ & 0 & 0 \\
\hline Mediāna & $\begin{array}{c}++/+++ \text { līdz } \\
+++\end{array}$ & $++/+++$ & $++/+++$ & ++ & +/++ & $0 /+$ \\
\hline $\begin{array}{l}\text { Kruskal- } \\
\text { Wallis } \\
\text { H-tests }\end{array}$ & \multicolumn{3}{|c|}{ p 0,003} & \multicolumn{3}{|c|}{ p $<$ <0,001 } \\
\hline $\begin{array}{l}\text { Mann- } \\
\text { Whitney } \\
\text { U-tests }\end{array}$ & \multicolumn{3}{|c|}{ p 0,876} & \multicolumn{3}{|c|}{ p 0,017} \\
\hline
\end{tabular}

* Apzīmējumi: AoV - deǵeneratīva aortālā vārstuḷa stenozes grupa, Il-10 - interleikīns 10, KSS - koronāras sirds slimības grupa.

Pozitīvo struktūru relatīvā daudzuma apzīmējumi: 0 redzes laukā netika konstatēta neviena pozitīva struktūra; 0/+ redzes laukā retas pozitīvas struktūras; + redzes laukā maz pozitīvu struktūru; +/++ redzes laukā maz līdz vidēji daudz pozit̄̄vu struktūru; ++ redzes laukā vidēji daudz pozit̄̄vu struktūru; ++/+++ redzes laukā vidēji daudz līdz daudz pozitīvu struktūru; +++ redzes laukā daudz pozitīvu struktūru; +++/++++ redzes laukā daudz līdz loti daudz pozitīvu struktūru; ++++ redzes laukā ḷoti daudz pozitīvu struktūru.

KSS grupā bija statistiski ticami vairāk Il-10 pozitīvu kardiomiocītu un endokarda endotēlija šūnu nekā AoV stenozes grupa (attiecīgi p 0,010 un p 0,017). Salīdzinot visas trīs grupas, statistiski ticama atšķirība bija gan Il-10 pozitīvu kardiomiocītu relatīvajā daudzumā (p 0,008), gan Il-10 pozitīvu saistaudu šūnu relatīvajā daudzumā (p 0,045), gan Il-10 pozitīvu asinsvadu un endokarda endotēlija šūnu relatīvajā daudzumā (p 0,003 un p <0,001). Apskatot kopā visus pacientus ar iegūtām sirdskaitēm, to Il-10 pozitīvo kardiomiocītu relatīvais daudzums uzrādīja vidēji ciešu negatīvu korelāciju ar triglicerīdu līmeni asin̄̄s $\left(\mathrm{r}_{\mathrm{s}}-0,357\right.$; p 0,035) un Il-10 pozitīvo endotēlija šūnu skaits labā priekškambara asinsvados uzrādīja vāju negatīvu korelāciju ar CRO līmeni asinīs ( $\mathrm{r}_{\mathrm{s}}-0,354$; $\mathrm{p}$ 0,034) (skatīt 3.10. tabulu).

Pacientiem ar KSS un iekaisuma šūnu infiltrāciju epikardā bija statistiski ticami vairāk Il-10 pozitīvu endotēlija šūnu labā priekškambara asinsvados (p 0,023) nekā pacientiem ar KSS bez iekaisuma šūnu infiltrācijas. Arī apskatot kopā visus pacientus ar iegūtām sirdskaitēm un 
iekaisuma šūnu infiltrāciju, novēroja tādu pašu tendenci - vairāk Il-10 pozitīvu endotēlija šūnu labā priekškambara asinsvados (p 0,006) nekā pacientiem ar iegūtām sirdskaitēm bez iekaisuma šūnu infiltrācijas labā priekškambara epikardā.

3.10. tabula

\section{Il-10 pozitīvo struktūru relatīvā daudzuma korelācijas ar pacientu pirmsoperācijas} klīniskajiem datiem

\begin{tabular}{|l|l|l|l|l|}
\hline \multicolumn{1}{|c|}{ Marḳieris1 } & \multicolumn{1}{c|}{ Grupa } & \multicolumn{1}{c|}{ Marḳieris2 } & \multicolumn{1}{c|}{ r $_{\text {s }}$} & \multicolumn{1}{c|}{ p } \\
\hline Il-10 kardiomiocitos & \multirow{2}{*}{ KSS } & Vecums & 0,596 & 0,002 \\
\hline \multirow{2}{*}{ Il-10 asinsvadu endotēlijāa } & \multirow{2}{*}{ KSS } & CRO & $-0,474$ & 0,019 \\
\cline { 3 - 5 } & & LKSS & 0,470 & 0,021 \\
\hline Il-10 endokarda endotēlijā & \multirow{2}{*}{ KSS } & KKEF grupas & $-0,441$ & 0,031 \\
\hline
\end{tabular}

* Apzīmējumi: CRO - c reaktīvais olbaltums, Il-10 -interleikīns 10, KSS - koronārā sirds slimība, LKSS - labā kambara sistoliskais spiediens, KKEF - kreisā kambara izsviedes frakcija (grupas: normāla KKEF EF 52-72 \%, viegli samazināta KKEF 41-51\%, mēreni samazināta 30-40\%, izteikti samazināta KKEF <30\% ), $\mathrm{r}_{\mathrm{s}}$ - Spīrmana rangu korelācijas koeficients.

\subsection{Beta defensīni}

\subsubsection{Beta defensīns 2 ( $\beta$ D2)}

$\beta$ D2 ekspresija bija vērojama visās pētījumā apskatītajās labā priekškambara audu grupās (skatīt 3.11. un 3.12. tabulu). Lai arī vairāk $\beta$ D2 pozitīvu šūnu bija paraugos, kas ņemti no pacientiem ar iegūtām sirdskaitēm, statistiski ticama atšķirība starp visām grupām bija tikai $\beta D 2$ pozitīvu endokarda endotēlija šūnu relatīvajā daudzumā $(p \quad 0,005)$.

KSS grupā visiem pacientiem labā priekškambara audu paraugos bija vismaz vidēji daudz (++) $\beta$ D2 pozitīvu kardiomiocītu, no kuriem vidēji daudz (++) tika novērots trim pacientiem, vidēji daudz līdz daudz $(++/+++)$ - sešiem pacientiem un daudz $(+++)$ 15 pacientiem (skatīt 48. attēlu pielikumā). AoV stenozes grupā tieši $50 \%$ pacientu bija daudz ßD2 pozitīvu kardiomiocītu, pārējiem 41,7 \% vidēji daudz līdz daudz (++/+++) un 8,3 \% maz līdz vidēji daudz (+/++) $\beta$ D2 pozitīvu kardiomiocītu (skatīt 49. attēlu pielikumā). Līdzīgi pacientiem ar iegūtām sirdskaitēm, arī kontroles grupā $\beta \mathrm{D} 2$ pozitīvu kardiomiocītu bija vidēji daudz līdz daudz $(++/+++)$ - četriem pacientiem - un daudz (+++) - vienam pacientam (skatīt 50. attēlu pielikumā).

$\beta \mathrm{D} 2$ pozitīvo saistaudu šūnu relatīvais daudzums paraugos KSS grupā variēja no to trūkuma septiņiem pacientiem līdz daudz $(+++)$ - 10 pacientiem, AoV stenozes grupā no nevienas līdz diviem pacientiem līdz daudz (+++) pozitīvām šūnām pieciem pacientiem, bet kontroles grupā no retām pozitīiām struktūrām redzes laukā $(0 /+)$ diviem pacientiem līdz vidēji daudz pozitīiām struktūrām redzes laukā $(++)$ vienam pacientam. $\beta$ D2 pozitīvo saistaudu šūnu 
relatīvā daudzuma mediāna KSS grupā bija vidēji daudz (++), AoV stenozes grupā vidēji daudz līdz daudz $(++/+++)$, bet kontroles grupā maz $(+)$.

3.11. tabula

ßD2 pozitīvo kardiomiocītu un saistaudu šūnu relatīvais daudzums labā priekškambara audos un tā statistiskais izvērtējums

\begin{tabular}{|c|c|c|c|c|c|c|}
\hline \multirow[b]{2}{*}{$\begin{array}{l}\text { Pozitīvo } \\
\text { struktūru } \\
\text { relatīvais } \\
\text { daudzums }\end{array}$} & \multicolumn{3}{|c|}{ Kardiomiocīti } & \multicolumn{3}{|c|}{ Saistaudu šūnas } \\
\hline & $\begin{array}{c}\text { KSS } \\
\text { n (\%) } \\
24(100 \%)\end{array}$ & $\begin{array}{c}\text { AoV } \\
\text { n (\%) } \\
12(100 \%)\end{array}$ & $\begin{array}{l}\text { Kontroles } \\
\text { grupa } \\
\text { n }(\%) \\
5(100 \%)\end{array}$ & $\begin{array}{c}\text { KSS } \\
\text { n }(\%) \\
24(100 \%)\end{array}$ & $\begin{array}{c}\text { AoV } \\
\text { n (\%) } \\
12(100 \%)\end{array}$ & $\begin{array}{c}\text { Kontroles } \\
\text { grupa } \\
\text { n }(\%) \\
5(100 \%)\end{array}$ \\
\hline 0 & 0 & 0 & 0 & $7(29,2 \%)$ & $2(16,7 \%)$ & 0 \\
\hline $0 /+$ & 0 & 0 & 0 & $1(4,2 \%)$ & 0 & $2(40,0 \%)$ \\
\hline+ & 0 & 0 & 0 & $1(4,2 \%)$ & $1(8,3 \%)$ & $2(40,0 \%)$ \\
\hline$+/++$ & 0 & $1(8,3 \%)$ & 0 & $1(4,2 \%)$ & $1(8,3 \%)$ & 0 \\
\hline++ & $3(12,5 \%)$ & 0 & 0 & $4(16,7 \%)$ & $1(8,3 \%)$ & $1(20,0 \%)$ \\
\hline$++/+++$ & $6(25,0 \%)$ & $5(41,7 \%)$ & $4(80,0 \%)$ & 0 & $2(16,7 \%)$ & 0 \\
\hline+++ & $15(62,5 \%)$ & $6(50,0 \%)$ & $1(20,0 \%)$ & $10(41,7 \%)$ & $5(41,7 \%)$ & 0 \\
\hline$+++/++++$ & 0 & 0 & 0 & 0 & 0 & 0 \\
\hline++++ & 0 & 0 & 0 & 0 & 0 & 0 \\
\hline Mediāna & +++ & $\begin{array}{c}++/+++ \text { lī } \mathrm{dz} \\
+++\end{array}$ & $++/+++$ & ++ & $++/+++$ & + \\
\hline $\begin{array}{l}\text { Kruskal- } \\
\text { Wallis } \\
\text { H-tests }\end{array}$ & \multicolumn{3}{|c|}{$\begin{array}{l} \\
p 0,425\end{array}$} & \multicolumn{3}{|c|}{ p 0,328} \\
\hline $\begin{array}{l}\text { Mann- } \\
\text { Whitney } \\
\text { U-tests }\end{array}$ & \multicolumn{3}{|c|}{ p 0,567} & \multicolumn{3}{|c|}{ p 0,573} \\
\hline
\end{tabular}

* Apzīmējumi: AoV - deǵeneratīva aortālā vārstuḷa stenozes grupa, KSS - koronāras sirds slimības grupa, $\beta$ D2 beta defensīns 2.

Pozitīvo struktūru relatīvā daudzuma apzīmējumi: 0 redzes laukā netika konstatēta neviena pozitīva struktūra; 0/+ redzes laukā retas pozitîvas struktūras; + redzes laukā maz pozitīvu struktūru; +/++ redzes laukā maz līdz vidēji daudz pozitīvu struktūru; ++ redzes laukā vidēji daudz pozitīvu struktūru; ++/+++ redzes laukā vidēji daudz līdz daudz pozitīvu struktūru; +++ redzes laukā daudz pozitīvu struktūru; +++/++++ redzes laukā daudz līdz loti daudz pozitīvu struktūru; ++++ redzes laukā ḷoti daudz pozitīvu struktūru.

Vismaz retas $\beta \mathrm{D} 2$ pozitīvas endotēlija šūnas labā priekškambara asinsvados bija atrodamas pilnīgi visos pētījumā iekḷautajos paraugos. KSS grupā trešdaḷā paraugu (33,3\%) bija vidēji daudz (++) $\beta$ D2 pozitīvu asinsvadu endotēlija šūnu (skatīt 51. attēlu pielikumā). AoV stenozes grupā diviem pacientiem bija ḷoti daudz $(++++)$. Kontroles grupā vairumam pacientu (60\%) bija maz (+), bet vienam pacientam vidēji daudz (++) $\beta$ D2 pozitīvu endotēlija šūnu labā priekškambara asinsvados (skatīt 52. attēlu pielikumā).

Vienam pacientam KSS grupā labā priekškambara audu paraugos bija maz (+) $\beta$ D2 pozitīvas endokarda endotēlija šūnas, četriem pacientiem vidēji daudz $(++)$, deviniiem pacientiem daudz $(+++)$, vienam pacientam daudz līidz ḷoti daudz $(+++/++++)$ (skatît 53. attēlu pielikumā), bet sešiem pacientiem ḷoti daudz $(++++)$ un trim pacientiem nebija atrodamas $\beta$ D2 
pozitīvas endokarda endotēlija šūnas labā priekškambara audu paraugos. Savukārt AoV stenozes grupā vienam pacientam bija retas $(0 /+) \beta D 2$ pozitīvas endokarda endotēlija šūnas redzes laukā, diviem pacientiem tādu bija maz $(+)$, vienam pacientam vidēji daudz līdz daudz $(++/+++)$ (skatīit 54. attēlu pielikumā), četriem pacientiem daudz $(+++)$ un četriem pacientiem l’oti daudz (++++). Iedzimtu sirdskaišu (kontroles) grupā tikai vienam pacientam labā priekškambara audu paraugā konstatēja maz $(+) \beta D 2$ pozitīvas endokarda endotēlija šūnu (skatīt 55. attēlu pielikumā), bet pārējiem $\beta D 2$ pozitīvas endokarda endotēlija šūnas netika konstatētas.

3.12. tabula

ßD2 pozitīvo asinsvadu un endokarda endotēlija šūnu relatīvais daudzums labā priekškambara audos un tā statistiskais izvērtējums

\begin{tabular}{|c|c|c|c|c|c|c|}
\hline \multirow[b]{2}{*}{$\begin{array}{c}\text { Pozitīvo } \\
\text { struktūru } \\
\text { relatīvais } \\
\text { daudzums }\end{array}$} & \multicolumn{3}{|c|}{ Asinsvadu endotēlijs } & \multicolumn{3}{|c|}{ Endokarda endotēlijs } \\
\hline & $\begin{array}{c}\text { KSS } \\
\text { n (\%) } \\
24(100 \%)\end{array}$ & $\begin{array}{c}\text { AoV } \\
\text { n }(\%) \\
12(100 \%)\end{array}$ & $\begin{array}{c}\text { Kontroles } \\
\text { grupa } \\
\text { n }(\%) \\
5(100 \%)\end{array}$ & $\begin{array}{c}\text { KSS } \\
\text { n (\%) } \\
24(100 \%)\end{array}$ & $\begin{array}{c}\text { AoV } \\
\text { n (\%) } \\
12(100 \%)\end{array}$ & $\begin{array}{c}\text { Kontroles } \\
\text { grupa } \\
\text { n }(\%) \\
5(100 \%)\end{array}$ \\
\hline 0 & 0 & 0 & 0 & $3(12,5 \%)$ & 0 & $4(80 \%)$ \\
\hline $0 /+$ & $5(20,8 \%)$ & $4(33,3 \%)$ & $1(20,0 \%)$ & 0 & $1(8,3 \%)$ & 0 \\
\hline+ & $3(12,5 \%)$ & $1(8,3 \%)$ & $3(60,0 \%)$ & $1(4,2 \%)$ & $2(16,7 \%)$ & $1(20,0 \%)$ \\
\hline$+/++$ & $1(4,2 \%)$ & 0 & 0 & 0 & 0 & 0 \\
\hline++ & $8(33,3 \%)$ & $1(8,3 \%)$ & $1(20,0 \%)$ & $4(16,7 \%)$ & 0 & 0 \\
\hline$++/+++$ & $2(8,3 \%)$ & $1(8,3 \%)$ & 0 & 0 & $1(8,3 \%)$ & 0 \\
\hline+++ & $5(20,8 \%)$ & $3(25,0 \%)$ & 0 & $9(37,5 \%)$ & $4(33,3 \%)$ & 0 \\
\hline$+++/++++$ & 0 & 0 & 0 & $1(4,2 \%)$ & 0 & 0 \\
\hline++++ & 0 & $2(16,7 \%)$ & 0 & $6(25,0 \%)$ & $4(33,3 \%)$ & 0 \\
\hline Mediāna & ++ & $\begin{array}{c}++\operatorname{li} \mathrm{dz} \\
++/+++\end{array}$ & + & +++ & +++ & 0 \\
\hline $\begin{array}{l}\text { Kruskal- } \\
\text { Wallis } \\
\text { H-tests }\end{array}$ & \multicolumn{3}{|c|}{ L } & \multicolumn{3}{|c|}{$\begin{aligned} \\
\text { p 0,005 }\end{aligned}$} \\
\hline $\begin{array}{l}\text { Mann- } \\
\text { Whitney } \\
\text { U-tests }\end{array}$ & \multicolumn{3}{|c|}{ p 0,583} & \multicolumn{3}{|c|}{ p 0,781} \\
\hline
\end{tabular}

* Apzīmējumi: AoV - deǵeneratīva aortālā vārstuḷa stenozes grupa, KSS - koronāras sirds slimības grupa, $\beta$ D2 beta defensīns 2 .

Pozitīvo struktūru relatīvā daudzuma apzīmējumi: 0 redzes laukā netika konstatêta neviena pozitīva struktūra; 0/+ redzes laukā retas pozitīvas struktūras; + redzes laukā maz pozitīvu struktūru; +/++ redzes laukā maz līdz vidēji daudz pozitīvu struktūru; ++ redzes laukā vidēji daudz pozitīvu struktūru; ++/+++ redzes laukā vidēji daudz līdz daudz pozitîvu struktūru; +++ redzes laukā daudz pozitīvu struktūru; +++/++++ redzes laukā daudz līdz loti daudz pozitīvu struktūru; ++++ redzes laukā ḷoti daudz pozitīvu struktūru.

$\beta \mathrm{D} 2$ pozitīvo struktūru relatīvā daudzuma statistiski ticamās korelācijas ar pacientu anamnēzes datiem attēlotas 3.13. un 3.14. tabulā. Statistiski nozīmīgas ciešas pozitīvas korelācijas KSS grupā tika konstatētas starp $\beta$ D2 pozitīvo kardiomiocītu un asinsvadu endotēlija šūnu relatīvo daudzumu un BNP līmeni ( $r_{s} 0,779 ; p$ 0,013 un $r_{s} 0,787 ; p$ 0,012). AoV 
stenozes grupā $\beta D 2$ pozitīvo kardiomiocītu relatīvais daudzums uzrādīja vidēji ciešu negatīvu korelāciju ar kopējā holesterīna un ZBLH līmeni, kā arī ar LKSS grupām $\left(\mathrm{r}_{\mathrm{s}}-0,685\right.$; p 0,014; $\mathrm{r}_{\mathrm{s}}-0,619 ; \mathrm{p} 0,032$ un $\mathrm{r}_{\mathrm{s}}-0,630 ; \mathrm{p}$ 0,028). Šajā pašā grupā līdzīgas - ciešas un vidēji ciešas negatīvas korelācijas tika novērotas arī starp $\beta \mathrm{D} 2$ pozitīvo saistaudu un kopējā holesterīna un ABLH līmeni, kā arī ar LKSS grupām $\left(r_{s}-0,736 ; p\right.$ 0,006; $r_{s}-0,629 ; p 0,028$ un $r_{s}-0,630$; p 0,028).

3.13. tabula

ßD2 pozitīvo kardiomiocītu un saistaudu šūnu relatīvā daudzuma statistiski nozīmīgās korelācijas ar pacientu datiem

\begin{tabular}{|c|c|c|c|c|}
\hline Markieris1 & Grupa & Markieris2 & $\mathbf{r}_{\mathrm{s}}$ & $\mathbf{p}$ \\
\hline \multirow{7}{*}{$\beta \mathrm{D} 2$ kardiomiocītos } & \multirow{3}{*}{ KSS } & Vecums & 0,465 & 0,437 \\
\hline & & ZBLH grupas & $-0,478$ & 0,025 \\
\hline & & BNP & 0,779 & 0,013 \\
\hline & \multirow{4}{*}{ AoV } & \begin{tabular}{|l|} 
Vecums \\
\end{tabular} & 0,579 & 0,049 \\
\hline & & Kopējais holesterīns & $-0,685$ & 0,014 \\
\hline & & ZBLH & $-0,619$ & 0,032 \\
\hline & & LKSS grupas & $-0,630$ & 0,028 \\
\hline \multirow{5}{*}{$\beta D 2$ saistaudos } & \multirow{2}{*}{ KSS } & Vecums & 0,437 & 0,033 \\
\hline & & ZBLH grupas & $-0,548$ & 0,008 \\
\hline & \multirow{3}{*}{ AoV } & Kopējais holesterīns & $-0,736$ & 0,006 \\
\hline & & ABLH & $-0,629$ & 0,028 \\
\hline & & LKSS grupas & $-0,630$ & 0,028 \\
\hline
\end{tabular}

* Apzīmējumi: ABLH - augsta blīvuma holesterīns, AoV - aortālā vārstula stenoze, BNP - smadzenu nātrijurētiskais peptīds, $\beta \mathrm{D} 2$ - beta defensīns 2 , KSS - koronāra sirds slimība, LKSS - labā kambara sistoliskais spiediens (grupas: normāls LKSS $<40 \mathrm{mmHg}$, viegli paaugstināts LKSS $41-55 \mathrm{mmHg}$, mēreni paaugstināts 55-70 mmHg un izteikti paaugstināts LKSS $>70 \mathrm{mmHg}$ ), $\mathrm{r}_{\mathrm{s}}$ - Spīrmana rangu korelācijas koeficients, ZBLH zema blīvuma holesterīns (grupas: $<1,8 \mathrm{mmol} / \mathrm{L} ; 1,81-2,5 \mathrm{mmol} / \mathrm{L} ; 2,5-3 \mathrm{mmol} / \mathrm{L}$ un $>3 \mathrm{mmol} / \mathrm{L}$ ).

3.14. tabula

ßD2 pozitīvo asinsvadu un endokarda endotēlija šūnu relatīvā daudzuma korelācijas ar pacientu pirmsoperācijas klīniskajiem datiem

\begin{tabular}{|c|c|c|c|c|}
\hline Mark̦ieris1 & Grupa & Mark̦ieris2 & $\mathbf{r}_{\mathrm{s}}$ & p \\
\hline \multirow{5}{*}{$\begin{array}{l}\beta \mathrm{D} 2 \text { asinsvadu } \\
\text { endotēlijā }\end{array}$} & \multirow{4}{*}{ KSS } & Kopējais holesterīns & $-0,493$ & 0,017 \\
\hline & & ZBLH grupas & $-0,437$ & 0,042 \\
\hline & & BNP & 0,787 & 0,012 \\
\hline & & LKSS grupas & 0,426 & 0,038 \\
\hline & AoV & Vecums & 0,590 & 0,043 \\
\hline \multirow{3}{*}{$\begin{array}{l}\text { BD2 endokarda } \\
\text { endotēlijā }\end{array}$} & \multirow{2}{*}{ KSS } & Kopējais holesterīns & $-0,474$ & 0,022 \\
\hline & & ZBLH grupas & $-0,459$ & 0,031 \\
\hline & AoV & LKSS & $-0,760$ & 0,004 \\
\hline
\end{tabular}

* Apzīmējumi: AoV - aortālā vārstuḷa stenoze, $\beta$ D2 - beta defensīns 2, BNP - smadzeņu nātrijurētiskais peptīds, KSS - koronāra sirds slimība, LKSS - labā kambara sistoliskais spiediens (grupas: normāls LKSS $<40 \mathrm{mmHg}$, viegli paaugstināts LKSS 41-55 $\mathrm{mmHg}$, mēreni paaugstināts 55-70 mmHg un izteikti paaugstināts LKSS >70 mmHg), $\mathrm{r}_{\mathrm{s}}$ - Spīrmana rangu korelācijas koeficients, ZBLH - zema blīvuma holesterīns (grupas: < 1,8 mmol/L; 1,81-2,5 $\mathrm{mmol} / \mathrm{L} ; 2,5-3 \mathrm{mmol} / \mathrm{L}$ un $>3 \mathrm{mmol} / \mathrm{L}$ ). 


\subsubsection{Beta defensīns 3 ( $\beta D 3)$}

Līdzīgi $\beta$ D2, arī $\beta$ D3 pozitīvo kardiomiocītu daudzums labā priekškambara audos visiem pacientiem ar KSS bija vismaz vidēji daudz (++) vai vairāk (skatīt 3.15. tabulu), respektīivi, vidēji daudz $(++)$ - trim pacientiem, vidēji daudz līdz daudz $(++/+++)$ - sešiem pacientiem, daudz $(+++)$ - 14 pacientiem un daudz līdz ļoti daudz $(+++/++++)$ - vienam pacientam (skatît 56. attēlu pielikumā). Pacientiem ar AoV stenozi $\beta$ D3 pozitīvo kardiomiocītu relatīvais daudzums redzes laukā bija šāds (skatīt 3.15. tabulu): maz $(+)$ - vienam pacientam, vidēji daudz $(++)$ - pieciem pacientiem, vidēji daudz līdz daudz $(++/+++)$ - trim pacientiem un pa vienam pacientam bija daudz $(+++)$, daudz līdz ḷoti daudz $(+++/+++)$ un ḷoti daudz $(++++)$. Visiem pacientiem kontroles grupā (skatīt 3.15. tabulu) labā priekškambara audu paraugos bija vidēji daudz līdz daudz (++/+++) $\beta$ D3 pozitīvu kardiomiocītu (skatît 57. attēlu pielikumā). Statistiski ticamas atšķirības $\beta \mathrm{D} 3$ pozitīvo kardiomiocītu relatīvajā daudzumā nebija ne starp visām trim grupām (p 0,061), ne atsevišķi starp pacientiem ar KSS un pacientiem ar deǵeneratīvu AoV stenozi (p 0,052). Pacientiem ar iegūtām sirdskaitēm un iekaisuma šūnu infiltrāciju epikardā bija statistiski ticami vairāk $\beta D 3$ pozitīivu kardiomiocītu labā priekškambara audos (p 0,034) nekā pacientiem bez iekaisuma šūnu infiltrācijas.

Arī $\beta D 3$ pozitīvo saistaudu šūnu relatīvajā daudzumā (skatīt 3.15. tabulu) nebija statistiski ticamas atšķirības ne starp visām trim grupām (p 0,216), ne atsevišķi starp iegūto sirdskaišu grupām (p 0,178). KSS grupā $\beta \mathrm{D} 3$ pozitīvo saistaudu šūnu relatīvais daudzums variēja no retām pozitīvām šūnām $(0 /+)$ pieciem pacientiem līdz daudz pozitīvām šūnām redzes laukā (+++) diviem pacientiem, bet mediāna bija vidēji daudz (++). Savukārt AoV stenozes grupā $\beta D 3$ pozitīvo saistaudu šūnu relatīvais daudzums variēja no nevienas diviem pacientiem līdz daudz (+++) pozitīvām šūnām redzes laukā diviem pacientiem un mediāna bija maz $(+)$ pozitīvu šūnu redzes laukā. Kontroles grupā diviem pacientiem bija atrodamas retas $\beta$ D3 pozitīvas saistaudu šūnas, diviem pacientiem bija maz līdz vidēji daudz $(+/++)$ un vienam pacientam bija vidēji daudz (++) $\beta$ D3 pozitīvu saistaudu šūnu.

Gan KSS grupā (skatīt 58. attēlu pielikumā), gan AoV stenozes grupā (skatīt 59. attēlu pielikumā) visvairāk bija pacientu ar vidēji daudz (++) $\beta$ D3 pozitīvām endotēlija šūnām labā priekškambara asinsvados, attiecīgi 45,8 \% un 33,3 \% (skatīt 3.16. tabulu). Iedzimtu sirdskaišu grupā vienam pacientam bija maz $(+)$, bet pārējiem četriem bija maz līdz vidēji daudz $(+/++) \beta D 3$ pozitīvu endotēlija šūnu labā priekškambara asinsvados. 
3.15. tabula

BD3 pozitīvo kardiomiocìtu un saistaudu šūnu relatīvais daudzums labā priekškambara audos un tā statistiskais izvērtējums

\begin{tabular}{|c|c|c|c|c|c|c|}
\hline \multirow[b]{2}{*}{$\begin{array}{l}\text { Pozitīvo } \\
\text { struktūru } \\
\text { relatīvais } \\
\text { daudzums }\end{array}$} & \multicolumn{3}{|c|}{ Kardiomiocīti } & \multicolumn{3}{|c|}{ Saistaudu šūnas } \\
\hline & $\begin{array}{c}\text { KSS } \\
\text { n (\%) } \\
24(100 \%)\end{array}$ & $\begin{array}{c}\text { AoV } \\
\text { n (\%) } \\
12(100 \%)\end{array}$ & $\begin{array}{l}\text { Kontroles } \\
\text { grupa } \\
\text { n }(\%) \\
5(100 \%)\end{array}$ & $\begin{array}{c}\text { KSS } \\
\text { n (\%) } \\
24(100 \%)\end{array}$ & $\begin{array}{c}\text { AoV } \\
\text { n }(\%) \\
12(100 \%)\end{array}$ & $\begin{array}{l}\text { Kontroles } \\
\text { grupa } \\
\text { n }(\%) \\
5(100 \%)\end{array}$ \\
\hline 0 & 0 & 0 & 0 & 0 & $2(16,7 \%)$ & 0 \\
\hline $0 /+$ & 0 & 0 & 0 & $5(20,8 \%)$ & $4(33,3 \%)$ & $2(40,0 \%)$ \\
\hline+ & 0 & $1(8,3 \%)$ & 0 & $3(12,5 \%)$ & 0 & 0 \\
\hline$+/++$ & 0 & 0 & 0 & $1(4,2 \%)$ & $1(8,3 \%)$ & $2(40,0 \%)$ \\
\hline++ & $3(12,5 \%)$ & $5(41,7 \%)$ & 0 & $9(37,5 \%)$ & $3(25,0 \%)$ & $1(20,0 \%)$ \\
\hline$++/+++$ & $6(2,50 \%)$ & $3(25,0 \%)$ & $5(100 \%)$ & $4(16,7 \%)$ & 0 & 0 \\
\hline+++ & $14(58,3 \%)$ & $1(8,3 \%)$ & 0 & $2(8,3 \%)$ & $2(16,7 \%)$ & 0 \\
\hline$+++/++++$ & $1(4,2 \%)$ & $1(8,3 \%)$ & 0 & 0 & 0 & 0 \\
\hline++++ & 0 & $1(8,3 \%)$ & 0 & 0 & 0 & 0 \\
\hline Mediāna & +++ & $\begin{array}{l}++ \text { lī } \mathrm{d} z \\
++/+++\end{array}$ & ++/+++ & ++ & + & +/++ \\
\hline $\begin{array}{l}\text { Kruskal- } \\
\text { Wallis } \\
\text { H-tests } \\
\end{array}$ & \multicolumn{3}{|c|}{ p 0,061} & \multicolumn{3}{|c|}{ p 0,216} \\
\hline $\begin{array}{l}\text { Mann- } \\
\text { Whitney } \\
\text { U-tests }\end{array}$ & \multicolumn{3}{|c|}{ p 0,052} & \multicolumn{3}{|c|}{ p 0,178} \\
\hline
\end{tabular}

* Apzīmējumi: AoV - deǵeneratīva aortālā vārstuḷa stenozes grupa, KSS - koronāras sirds slimības grupa, $\beta \mathrm{D} 3$ beta defensīns 3 .

Pozitīvo struktūru relatīvā daudzuma apzīmējumi: 0 redzes laukā netika konstatēta neviena pozitīva struktūra; 0/+ redzes laukā retas pozitīvas struktūras; + redzes laukā maz pozitīvu struktūru; +/++ redzes laukā maz līdz vidēji daudz pozit̄̄vu struktūru; ++ redzes laukā vidēji daudz pozit̄̄vu struktūru; ++/+++ redzes laukā vidēji daudz līdz daudz pozitīvu struktūru; +++ redzes laukā daudz pozitīvu struktūru; +++/++++ redzes laukā daudz līdz loti daudz pozitīvu struktūru; ++++ redzes laukā ḷoti daudz pozitīvu struktūru.

$\beta$ D3 ekspresija tika novērota gan endokarda endotēlija šūnās, gan epikarda epitēlija šūnās (skatīt 60. attēlu pielikumā). Līdzīgi $\beta D 2$ ekspresijai vienīgā statistiski nozīmīgā atškirība starp visām trim grupām tika novērota $\beta \mathrm{D} 3$ pozitīvo endokarda endotēlija šūnu daudzumā (p 0,017), kur mediāna gan KSS grupā, gan AoV stenozes grupā bija daudz pozitīvas šūnas redzes laukā $(+++)$, bet kontroles grupā - retas pozitīvas šūnas redzes laukā $(0 /+)$ (skatīt 3.16. tabulu). KSS grupā tikai $16,6 \%$ pacientu bija mazāk nekā vidēji daudz līdz daudz $(++/+++)$ pozitīvu endokarda endotēlija šūnu (skatīt 61. attēlu pielikumā). AoV stenozes grupā pa vienam pacientam bija neviena, retas pozitīvas šūnas $(0 /+)$ un maz $(+) \beta D 3$ pozitīvu endokarda endotēlija šūnu redzes laukā, pa diviem pacientiem bija vidēji daudz $(++)$, daudz $(+++)$ un daudz līdz ļoti daudz $(+++/+++)$, bet trim pacientiem ļoti daudz $\beta$ D3 pozitīvu endokarda endotēlija šūnu (skatīt 62. attēlu pielikumā). Savukārt kontroles grupā vienam pacientam netika atrastas $\beta$ D3 pozitīvas endotēlija šūnas, diviem pacientiem bija retas 
(0/+) $\beta \mathrm{D} 3$ pozitīvas endokarda endotēlija šūnas, bet diviem pacientiem bija maz līdz vidēji daudz (+/++) $\beta$ D3 pozitīvu endokarda endotēlija šūnu.

3.16. tabula

ßD3 pozitīvo asinsvadu un endokarda endotēlija šūnu relatīvais daudzums labā priekškambara audos un tā statistiskais izvērtējums

\begin{tabular}{|c|c|c|c|c|c|c|}
\hline \multirow[b]{2}{*}{$\begin{array}{c}\text { Pozitīvo } \\
\text { struktūru } \\
\text { relatīvais } \\
\text { daudzums }\end{array}$} & \multicolumn{3}{|c|}{ Asinsvadu endotēlijs } & \multicolumn{3}{|c|}{ Endokarda endotēlijs } \\
\hline & $\begin{array}{c}\text { KSS } \\
\text { n (\%) } \\
24(100 \%)\end{array}$ & $\begin{array}{c}\text { AoV } \\
\text { n (\%) } \\
12(100 \%)\end{array}$ & $\begin{array}{l}\text { Kontroles } \\
\text { grupa } \\
\text { n }(\%) \\
5(100 \%) \\
\end{array}$ & $\begin{array}{c}\text { KSS } \\
\text { n (\%) } \\
24(100 \%)\end{array}$ & $\begin{array}{c}\text { AoV } \\
\text { n (\%) } \\
12(100 \%)\end{array}$ & $\begin{array}{l}\text { Kontroles } \\
\text { grupa } \\
\text { n }(\%) \\
5(100 \%) \\
\end{array}$ \\
\hline 0 & $2(8,3 \%)$ & 0 & 0 & 0 & $1(8,3 \%)$ & $1(20,0 \%)$ \\
\hline $0 /+$ & $1(4,2 \%)$ & $3(25,0 \%)$ & 0 & $2(8,3 \%)$ & $1(8,3 \%)$ & $2(40,0 \%)$ \\
\hline+ & $1(4,2 \%)$ & $2(16,7 \%)$ & $1(20,0 \%)$ & $2(8,3 \%)$ & $1(8,3 \%)$ & 0 \\
\hline$+/++$ & $1(4,2 \%)$ & $1(8,3 \%)$ & $4(80,0 \%)$ & 0 & 0 & $2(40,0 \%)$ \\
\hline++ & $11(45,8 \%)$ & $4(33,3 \%)$ & 0 & 0 & $2(16,7 \%)$ & 0 \\
\hline$++/+++$ & $3(12,5 \%)$ & $1(8,3 \%)$ & 0 & $4(16,7 \%)$ & 0 & 0 \\
\hline+++ & $5(20,8 \%)$ & 0 & 0 & $7(29,2 \%)$ & $2(16,7 \%)$ & 0 \\
\hline$+++/++++$ & 0 & $1(8,3 \%)$ & 0 & $5(20,8 \%)$ & $2(16,7 \%)$ & 0 \\
\hline++++ & 0 & \begin{tabular}{|l}
0 \\
\end{tabular} & 0 & $4(16,7 \%)$ & $3(25,0 \%)$ & 0 \\
\hline Mediāna & ++ & $\begin{array}{c}+++ \text { līdz } \\
++\end{array}$ & +/++ & +++ & +++ & $0 /+$ \\
\hline $\begin{array}{l}\text { Kruskal- } \\
\text { Wallis } \\
\text { H-tests }\end{array}$ & \multicolumn{3}{|c|}{ p 0,064} & \multicolumn{3}{|c|}{$\begin{aligned} \\
\text { p } 0,017\end{aligned}$} \\
\hline $\begin{array}{l}\text { Mann- } \\
\text { Whitney } \\
\text { U-tests }\end{array}$ & \multicolumn{3}{|c|}{ p 0,147} & \multicolumn{3}{|c|}{ p 0,785} \\
\hline
\end{tabular}

* Apzīmējumi: AoV - deǵeneratīva aortālā vārstuḷa stenozes grupa, KSS - koronāras sirds slimības grupa, $\beta$ D3 beta defensīns 3 .

Pozitīvo struktūru relatīvā daudzuma apzīmējumi: 0 redzes laukā netika konstatēta neviena pozitīva struktūra; 0/+ redzes laukā retas pozitīvas struktūras; + redzes laukā maz pozitīvu struktūru; +/++ redzes laukā maz līdz vidēji daudz pozitīvu struktūru; ++ redzes laukā vidēji daudz pozit̄̄vu struktūru; ++/+++ redzes laukā vidēji daudz līdz daudz pozitīvu struktūru; +++ redzes laukā daudz pozitīvu struktūru; $+++/++++$ redzes laukā daudz līdz ḷoti daudz pozitīvu struktūru; ++++ redzes laukā ḷoti daudz pozitīvu struktūru. 
ßD3 pozitīvo struktūru relatīvā daudzuma korelācijas ar pacientu datiem

\begin{tabular}{|l|l|l|l|l|}
\hline \multicolumn{1}{|c|}{ Mark̦ieris1 } & \multicolumn{1}{c|}{ Grupa } & \multicolumn{1}{c|}{ Marḳieris2 } & \multicolumn{1}{c|}{$\mathbf{r}_{\text {s }}$} & \multicolumn{1}{c|}{ p } \\
\hline$\beta D$ kardiomiocītos & KSS & BNP & 0,745 & 0,021 \\
\hline \multirow{2}{*}{$\beta$ D3 saistaudos } & KSS & LKSS grupas & 0,431 & 0,036 \\
\cline { 2 - 5 } & AoV & Kopējais holesterīns & $-0,627$ & 0,029 \\
\hline $\begin{array}{l}\beta D 3 \text { asinsvadu } \\
\text { endotēlijā }\end{array}$ & KSS & LKSS & 0,477 & 0,018 \\
\hline $\begin{array}{l}\beta D 3 \text { endokarda } \\
\text { endotēlijā }\end{array}$ & KSS & Kopējais holesterīns & $-0,553$ & 0,006 \\
\hline
\end{tabular}

* Apzīmējumi: AoV - aortālā vārstuḷa stenoze, $\beta$ D3 - beta defensīns 3, BNP - smadzeṇu nātrijurētiskais peptīds, CRO - c reaktīvais olbaltums, KSS - koronāra sirds slimība, LKSS - labā kambara sistoliskais spiediens (grupas: normāls LKSS $<40 \mathrm{mmHg}$, viegli paaugstināts LKSS 41-55 mmHg, mēreni paaugstināts $55-70 \mathrm{mmHg}$ un izteikti paaugstināts LKSS $>70 \mathrm{mmHg}), \mathrm{r}_{\mathrm{s}}$ - Spīrmana rangu korelācijas koeficients, ZBLH - zema blīvuma holesterīns.

\subsubsection{Beta defensīns 4 ( $\beta$ D4)}

ßD4 pozitīvas struktūras netika konstatētas nevienā no preparātiem (skatît 63. attēlu pielikumā).

\subsection{Datu statistiskās korelācijas}

KSS grupā statistiski nozīmīga cieša pozitīva korelācija tika konstatēta starp $\beta \mathrm{D} 2$ pozitīvo kardiomiocītu relatīvo daudzumu un $\beta \mathrm{D} 2$ pozitīvo asinsvadu endotēlija šūnu relatīvo daudzumu labā priekškambara audos $\left(\mathrm{r}_{\mathrm{s}} 0,710, \mathrm{p}<0,001\right)$.

Pêtījumā apskatīto audu marķieru relatīvo daudzumu statistiski nozīmīgās vidēji ciešās pozitīvās un negatīvās korelācijas KSS grupā attēlotas 3.18. un 3.19. tabulā.

Audu marḳieru savstarpējās statistiski nozīmīgās vidēji ciešās pozitīvās korelācijas koronāras sirds slimības grupā

\begin{tabular}{|l|l|l|l|}
\hline \multicolumn{1}{|c|}{ Marḳieris 1 } & \multicolumn{1}{c|}{ Mark̦ieris 2 } & \multicolumn{1}{c|}{$\mathbf{r}_{\mathbf{s}}$} & \multicolumn{1}{c|}{ p } \\
\hline Apoptoze & Il-10 kardiomiocītos & 0,438 & 0,032 \\
\hline \multirow{4}{*}{ ANUP } & ET-1 asinsvados & 0,448 & 0,028 \\
\cline { 2 - 5 } & $\beta \mathrm{D} 2$ asinsvados & 0,407 & 0,048 \\
\hline \multirow{5}{*}{ ChgA endokardā } & VEGF endokardā & 0,645 & 0,001 \\
\cline { 2 - 5 } & Il-1 $\alpha$ endokardā & 0,490 & 0,015 \\
\cline { 2 - 5 } & Il-10 endokardā & 0,522 & 0,009 \\
\cline { 2 - 5 } & $\beta \mathrm{D} 2$ endokardā & 0,431 & 0,036 \\
\cline { 2 - 5 } & $\beta \mathrm{D} 2$ asinsvados & 0,405 & 0,049 \\
\cline { 2 - 5 } & $\beta \mathrm{D} 3$ saistaudos & 0,472 & 0,020 \\
\cline { 2 - 4 } & $\beta \mathrm{D} 3$ endokardā & 0,557 & 0,005 \\
\hline
\end{tabular}


3.18. tabulas turpinājums

\begin{tabular}{|c|c|c|c|}
\hline Marḳieris 1 & Marḳieris 2 & $\mathbf{r}_{\mathrm{s}}$ & $\mathbf{p}$ \\
\hline ET-1 asinsvados & ET-1 endokardā & 0,486 & 0,016 \\
\hline \multirow{2}{*}{ VEGF endokardā } & Il-10 endokardā & 0,468 & 0,021 \\
\hline & $\beta \mathrm{D} 3$ endokardā & 0,431 & 0,036 \\
\hline \multirow{3}{*}{ Il-1 $\alpha$ endokardā } & Il-10 saistaudos & 0,417 & 0,043 \\
\hline & $\beta \mathrm{D} 3$ kardiomiocìtos & 0,509 & 0,011 \\
\hline & $\beta$ D3 saistaudos & 0,528 & 0,008 \\
\hline \multirow{2}{*}{ Il-10 kardiomiocītos } & $\beta \mathrm{D} 2$ kardiomiocītos & 0,425 & 0,038 \\
\hline & $\beta \mathrm{D} 2$ saistaudos & 0,571 & 0,004 \\
\hline \multirow{5}{*}{ Il-10 saistaudos } & $\beta \mathrm{D} 2$ kardiomiocìtos & 0,512 & 0,011 \\
\hline & $\beta$ D2 saistaudos & 0,522 & 0,009 \\
\hline & $\beta \mathrm{D} 2$ asinsvados & 0,464 & 0,022 \\
\hline & $\beta \mathrm{D} 3$ kardiomiocītos & 0,521 & 0,009 \\
\hline & $\beta$ D3 saistaudos & 0,483 & 0,017 \\
\hline Il-10 asinsvados & $\beta \mathrm{D} 3$ asinsvados & 0,435 & 0,034 \\
\hline \multirow{2}{*}{ Il-10 endokardā } & $\beta \mathrm{D} 2$ kardiomiocītos & 0,498 & 0,013 \\
\hline & $\beta \mathrm{D} 2$ asinsvados & 0,452 & 0,026 \\
\hline \multirow{2}{*}{$\beta \mathrm{D} 2$ kardiomiocītos } & $\beta \mathrm{D} 2$ endokardā & 0,603 & 0,002 \\
\hline & $\beta$ D3 saistaudos & 0,553 & 0,005 \\
\hline \multirow{4}{*}{$\beta \mathrm{D} 2$ endokardā } & $\beta \mathrm{D} 2$ saistaudos & 0,644 & 0,001 \\
\hline & $\beta \mathrm{D} 2$ asinsvados & 0,664 & $<0,001$ \\
\hline & $\beta \mathrm{D} 3$ saistaudos & 0,408 & 0,048 \\
\hline & $\beta \mathrm{D} 3$ endokardā & 0,688 & $<0,001$ \\
\hline \multirow{4}{*}{$\beta \mathrm{D} 2$ saistaudos } & $\beta \mathrm{D} 2$ asinsvados & 0,622 & 0,001 \\
\hline & $\beta \mathrm{D} 3$ kardiomiocìtos & 0,420 & 0,041 \\
\hline & $\beta$ D3 saistaudos & 0,554 & 0,005 \\
\hline & $\beta \mathrm{D} 3$ endokardā & 0,495 & 0,014 \\
\hline$\beta \mathrm{D} 2$ asinsvados & $\beta \mathrm{D} 3$ saistaudos & 0,498 & 0,013 \\
\hline$\beta \mathrm{D} 3$ kardiomiocītos & $\beta$ D3 saistaudos & 0,421 & 0,040 \\
\hline$\beta$ D3 saistaudos & $\beta \mathrm{D} 3$ endokardā & 0,410 & 0,047 \\
\hline
\end{tabular}

* Apzīmējumi: ChgA - hromogranīns A, ET-1 - endotelīns 1, Il-10 - interleikīns 10, Il-1 $\alpha$ - interleikīns 1 $\alpha$, PGP 9.5 - proteīna gēna produkts 9.5 , VEGF - asinsvadu endotēlija augšanas faktors, $\beta \mathrm{D} 2$ - beta defensīns $2, \beta \mathrm{D} 3$ beta defensīns 3 .

3.19. tabula

Audu marḳieru savstarpējās statistiski nozīmīgās vidēji ciešās negatīvās korelācijas koronāras sirds slimības grupā

\begin{tabular}{|l|l|r|l|}
\hline \multicolumn{1}{|c|}{ Marķieris 1 } & \multicolumn{1}{|c|}{ Marḳieris 2 } & \multicolumn{1}{c|}{$\mathbf{r}_{\mathbf{s}}$} & \multicolumn{1}{c|}{ p } \\
\hline ET-1 asinsvados & $\beta \mathrm{D} 3$ endokardā & $-0,417$ & 0,043 \\
\hline \multirow{5}{*}{ PGP 9.5 saturoša inervācija } & $\mathrm{Il}-10$ kardiomiocītos & $-0,456$ & 0,025 \\
\cline { 2 - 5 } & $\beta \mathrm{D} 2$ kardiomiocītos & $-0,553$ & 0,005 \\
\cline { 2 - 5 } & $\beta \mathrm{D} 2$ endokardā & $-0,438$ & 0,032 \\
\cline { 2 - 5 } & $\beta \mathrm{D} 2$ saistaudos & $-0,610$ & 0,002 \\
\cline { 2 - 5 } & $\beta \mathrm{D} 2$ asinsvados & $-0,525$ & 0,008 \\
\cline { 2 - 5 } & $\beta \mathrm{D} 3$ saistaudos & $-0,501$ & 0,013 \\
\hline
\end{tabular}

* Apzīmējumi: ET-1 - endotelīns 1, Il-10 - interleikīns 10, PGP 9.5 - proteīna gēna produkts 9.5, $\beta$ D2 - beta defensīns 2, $\beta$ D3 - beta defensīns 3. 
Deǵeneratīvas AoV stenozes grupā statistiski nozīmīga vidēji cieša negatīva korelācija tika konstatēta starp apoptotisko kardiomiocītu relatīvo daudzumu un ChgA pozitīvo endokarda endotēlija šūnu relatīvo daudzumu labā priekškambara audos $\left(r_{s}-0,633, p\right.$ 0,027).

Pētījumā apskatîto audu marḳieru relatīvo daudzumu statistiski nozīmīgās ciešās un vidēji ciešās pozitīvās korelācijas AoV stenozes grupā attēlotas 3.20. un 3.21. tabulā.

3.20. tabula

\section{Audu marḳieru savstarpējās statistiski ticamās ciešās pozitīvās korelācijas} aortālā vārstuḷa stenozes grupā

\begin{tabular}{|l|l|l|l|}
\hline \multicolumn{1}{|c|}{ Markkieris 1 } & \multicolumn{1}{c|}{ Marķieris 2 } & \multicolumn{1}{c|}{ r $_{\text {s }}$} & \multicolumn{1}{c|}{ p } \\
\hline ET-1 asinsvados & Il-10 asinsvados & 0,777 & 0,003 \\
\hline ET-1 endokardā & VEGF endokardā & 0,732 & 0,010 \\
\hline Il-10 saistaudos & $\beta \mathrm{D} 3$ asinsvados & 0,746 & 0,005 \\
\hline \multirow{3}{*}{$\beta \mathrm{D} 2$ kardiomiocītos } & $\beta \mathrm{D} 2$ saistaudos & 0,901 & $<0,001$ \\
\cline { 2 - 5 } & $\beta \mathrm{D} 2$ asinsvados & 0,711 & 0,009 \\
\cline { 2 - 5 } & $\beta \mathrm{D} 3$ saistaudos & 0,715 & 0,009 \\
\hline$\beta \mathrm{D} 2$ endokardā & $\beta \mathrm{D} 2$ saistaudos & 0,713 & 0,009 \\
\hline \multirow{2}{*}{$\beta \mathrm{D} 2$ saistaudos } & $\beta \mathrm{D} 2$ asinsvados & 0,707 & 0,010 \\
\cline { 2 - 5 } & $\beta \mathrm{D} 3$ saistaudos & 0,719 & 0,008 \\
\hline$\beta \mathrm{D} 3$ saistaudos & $\beta \mathrm{D} 3$ endokardā & 0,769 & 0,003 \\
\hline
\end{tabular}

* Apzīmējumi: ET-1 - endotelīns 1, Il-10 - interleikīns 10, VEGF - asinsvadu endotēlija augšanas faktors, $\beta$ D2 beta defensīns $2, \beta \mathrm{D} 3$ - beta defensīns 3 .

3.21. tabula

Audu marḳieru savstarpējās statistiski ticamās vidēji ciešās pozitīvās korelācijas aortālā vārstuḷa stenozes grupā

\begin{tabular}{|l|l|l|l|}
\hline \multicolumn{1}{|c|}{ Mark̦ieris 1 } & \multicolumn{1}{c|}{ Markiieris 2 } & \multicolumn{1}{c|}{$\mathbf{r}_{\text {s }}$} & \multicolumn{1}{c|}{ p } \\
\hline \multirow{5}{*}{ Apoptoze } & Il-1 $\alpha$ saistaudos & 0,591 & 0,043 \\
\cline { 2 - 5 } & $\beta \mathrm{D} 2$ kardiomiocītos & 0,597 & 0,041 \\
\cline { 2 - 5 } & $\beta \mathrm{D} 2$ saistaudos & 0,613 & 0,034 \\
\cline { 2 - 5 } & $\beta \mathrm{D} 3$ endokardā & 0,628 & 0,029 \\
\hline Apoptotiskais indekss & VEGF asinsvados & 0,695 & 0,018 \\
\hline \multirow{2}{*}{$\beta \mathrm{D} 2$ kardiomiocītos } & $\beta \mathrm{D} 2$ endokardā & 0,667 & 0,018 \\
\cline { 2 - 5 } & $\beta \mathrm{D} 3$ endokardā & 0,632 & 0,027 \\
\hline$\beta \mathrm{D} 2$ endokardā & $\beta \mathrm{D} 2$ asinsvados & 0,640 & 0,025 \\
\hline \multirow{3}{*}{$\beta \mathrm{D} 2$ asinsvados } & $\beta \mathrm{D} 3$ saistaudos & 0,654 & 0,021 \\
\cline { 2 - 5 } & $\beta \mathrm{D} 3$ endokardā & 0,646 & 0,023 \\
\cline { 2 - 5 } & $\beta \mathrm{D} 3$ asinsvados & 0,690 & 0,013 \\
\hline
\end{tabular}

* Apzīmējumi: Il-10 - interleikīns 10, Il-1 $\alpha$ - interleikīns $1 \alpha$, PGP 9.5 - proteīna gēna produkts 9.5, VEGF asinsvadu endotēlija augšanas faktors, $\beta$ D2 - beta defensīns $2, \beta D 3$ - beta defensīns 3 . 


\section{Diskusija}

Šajā pētijumā noteicām dažādus audu, inervācijas, iekaisuma, pretiekaisuma faktorus un antimikrobos peptīdus labā priekškambara audos pacientiem ar KSS un deǵeneratīvu AoV stenozi, kā kontroles grupu izmantojot labā priekškambara audu paraugus no pacientiem ar iedzimtām sirdskaitēm, kas operēti agrīnā vecumā. KSS un değeneratīvai AoV stenozei ir līdz̄̄gi etioloğiskie faktori un lokāli patoǵenētiskie procesi, taču ne vienmēr tās novēro abas reizē. Kopumā noteicām 10 dažādus marḳierus: apoptozi, ANUP, VEGF, PGP 9.5 saturošu inervāciju, ChgA, ET-1, Il-1 $\alpha$, Il-10, $\beta \mathrm{D} 2, \beta \mathrm{D} 3$ un $\beta \mathrm{D} 4$. Līdz šim šādā kombinācijā tie vēl nav pētîti, un, tā kā daži no šiem marķieriem jau ir sen zināmi un plaši pêtīiti, saliekot tos kopāa ar mazāk zināmiem, gūstam plašāku ieskatu par morfologiskajām norisēm labā priekškambara audos pacientiem ar KSS un deǵeneratīvu AoV stenozi, kas uzskatāma par darba novitāti.

Nevienā no paraugiem netika konstatēti morfoloǵiski veseli labā priekškambara audi ne paraugos, kas ñemti no pacientiem ar KSS, ne no pacientiem ar deǵeneratīvu AoV stenozi, ne no pacientiem ar iedzimtām sirdskaitēm jeb kontroles grupas. Gandrīz visos paraugos konstatēja miokarda deǵenerāciju ar vairāk vai mazāk izteiktu kardiomiocītu vakuolizāciju. Vakuolizācija var būt atgriezeniska, to novēro kaitīgā aǵenta iedarbības laikā, un šūnas struktūra atjaunojas, kad šĩ iedarbība tiek novērsta (Cohen et al., 1979). Taču vakuolizācija var būt arī neatgriezeniska, tādā gadījumā tā ir nespecifiska pazīme, kas iezīmē patologiiskus apstākḷus, kuri noved pie šūnu nāves (Shubin et al., 2016). Šīs izmainas sakrīt ar pētījuma paraugos konstatēto lielo apoptotisko indeksu, lai arī statistiski ticamu korelāciju starp šīm pazīmēm nekonstatējām. Jāpiebilst, ka arī mūsu pētījumā novērotās kardiomiocītu kodolu formas izmaiņas netieši apliecina apoptozes sākšanos, kuras pamatā ir DNS fragmentācija. Kā viens no iespējamiem iemesliem neatgriezeniskai šūnu vakuolizācijai un apoptozei literatūrā minēts baktēriju vai vīrusu patogēnā iedarbība uz šn̄nu, piemēram, B hepatīta vīrusa virsmas proteīns izraisa akūtu aknu šūnu vakuolizāciju ar sekojošu apoptozi (Foo et al., 2002).

\subsection{Endokarda endotēlijs}

Vēl viena raksturīga pazīme, ko konstatèjām lielā dalıā pêtījuma audu, kas ņemti no pacientiem ar iegūtām sirdskaitēm, bija endokarda endotēlija šūnu formas izmaiņas. Endokarda endotēlija šn̄nas normā ir vienkārtains plakanā epitēlija šn̄nu slānis, kas izklāj sirds dobumus, veidojot barjeru starp cirkulējošām asinīm un miokardu, tajā pašā laikā tieši mijiedarbojoties ar blakus esošajiem kardiomiocīiem. Tās tāpat kā asinsvadu endotēlija šūnas producē un izdala dažādas vielas, piemēram, slāpekḷa oksīdu, ET-1, prostaglandīnu $\mathrm{I}_{2}$ un angiotenzīnu II, ar auto 
un parakrīnu funkciju, tādā veidā regulējot arī miokarda metabolismu, augšanu un kontraktilitāti (Brutsaert et al., 1988; Brutsaert, 2003). Atšķirībā no asinsvadiem, kur endotēlijs mijiedarbojas ar paša asinsvada gludo muskulatūru, regulējot asins apgādi, endokarda endotēlijs atrodas tuvu blakus esošajiem kardiomiocītiem, nodrošinot tiešu signālu pārvadi un komunikāciju. Lielā dạ̣ā audu paraugu gan no pacientiem ar KSS, gan no pacientiem ar deǵeneratīvu AoV stenozi konstatēja endokarda fragmentus ar kubiskas formas endoteliocītiem, kas vairumā gadījumu uzrādīja pozitīvu reakciju uz visiem pārbaudītajiem audu faktoriem. Jāatzīmē, ka šādas izmaiņas netika konstatētas kontroles grupā - audu paraugos, kas ņemti no pacientiem ar iedzimtām sirdskaitēm. Pētījumi rāda, ka, piemēram, iedzimtas hipertrofiskās kardiomiopātijas gadījumā endokarda endotēlija hipertrofija attīstās jau pirms miokarda hipertrofijas, turklāt palielināts endotēlija šūnu apjoms saglabājās visu hipertrofiskās kardiomiopātijas attīstības laiku (Jacques and Bkaily, 2019). Mūsu pētījumā pacientiem ar KSS un kubiskas formas endokardu bija pārliecinoši vairāk VEGF pozitīvu endokarda endotēlija šūnu nekā pacientiem ar KSS un plakanas formas endokarda endoteliocītiem, kas varētu norādīt uz išēmijas iespējamo ietekmi endokarda endoteliocītu formas maiṇai, līdzīgi kā tas notiek acs tīklenes kapilāros (Hofman et al., 2001). Gan genētiski ieprogrammēta, gan hipoksijas inducēta VEGF produkcija ir kritiski svarīga arī sākotnējā endokarda endotēlija diferenciācijā un proliferācijā (Dor et al., 2003).

Gan KSS, gan AoV stenozes grupā vairumā paraugu endokarda endotēlija šūnas uzrādīja pozitīvu reakciju arī uz ChgA, ET-1, Il-1 $\alpha$, Il-10, $\beta$ D2 un $\beta$ D3. Iedzimtu sirdskaišu jeb kontroles grupā labā priekškambara endokarda endotēlijā konstatējām tikai pretiekaisuma citokīnu Il-10 un antimikrobos peptīdus $\beta$ D2 un $\beta$ D3.

No pētījumiem par asinsvadu endotēliju zināms, ka ChgA inhibē proinflamatora citokīna tumora nekrozes faktora alfa (TNF $\alpha)$ izraisītu endotēlija šūnu citoskeleta reorganizāciju, novēršot palielinātu asinsvadu caurlaidību (Ferrero et al., 2004). TNFa ir nozīmīgs patoǵenēzes faktors gan pacientiem ar KSS, gan pacientiem ar deǵeneratīvu AoV stenozi (Galeone et al., 2013; Carlsson et al., 2018), turklāt tas izraisa pārmērīgu iekaisuma reakciju, izjaucot homeostāzi un potencējot sirds mazspēju (Schumacher and Prasad, 2018). Kā viens no galvenajiem TNFa darbības mehānismiem ir asinsvadu caurlaidības palielināšanās (Ferrero et al., 2001); līdz ar to endokarda endotēlijā esošais ChgA varētu no tās pasargāt endokarda endotēliju.

Sirdī ET-1 sekretē galvenokārt intramiokardiālo kapilāru endotēlija šūnas, bet ET ekspresija konstatēta arī endokarda endotēlija šūnās, kardiomiocītos, asinsvadu gludās muskulatūras šūnās, makrofāgos u.c. (Miyauchi and Sakai, 2019). Mūsu pētījuma paraugos gan 
KSS, gan AoV stenozes pacientiem vairāk bija ET-1 pozitīvu endokarda endotēlija šūnu. Tāpat kā pētījumos par ET-1 ekspresiju dažādos sirds audos sirds mazspējas pacientiem (Fukuchi and Giaid, 1998), mūsu pêtījumā piln̄̄gi visos paraugos no pacientiem ar iegūtām sirdskaitēm, izṇemot vienu paraugu no pacienta ar deǵeneratīvu AoV stenozi, labā priekškambara endokarda endotēlijā tika konstatēta ET-1 klātbūtne. Pretēji pētījumiem par asins plazmā esošo ET-1 (Cody et al., 1993) mūsu pētījumā netika konstatēta korelācija starp ET-1 pozitīvo labā priekškambara endokarda endotēlija šūnu relatīvo daudzumu un pulmonālu hipertensiju. Jāatzīmēe, ka pacientiem ar AoV stenozi, kas pastāvīgi lietoja statīnus, bija statistiski ticami mazāk ET-1 pozitīvu endotēlija šūnu labā priekškambara endokardā nekā pacientiem, kas statīnus nelietoja. Šo atradni pamato fakts, ka statīni inhibē preproendotelīna-1 gēna transkripciju endotēlija šūnās, tādā veidā reducējot ET-1 sintēzi (Hernández-Perera et al., 2000). Turklāt statīni ne tikai samazina ET-1 sintēzi endotēlija šūnās, bet arī inhibē ET-1 izraisītu vazokonstrikciju (Mraiche et al., 2005).

Minētais liecina, ka KSS un deǵeneratīvas AoV stenozes gadījumā notiek labā priekškambara endokarda endotēlija šūnu aktivācija, līdz ar to endokarda endotēlijs ir mērḳa audi arī kompleksā šo slimību ārstēšanā.

\subsection{Inervācija}

Vesela sirds ir bagātīgi inervēta ar simpātiskām un parasimpātiskām nervu šķiedrām, kas nodrošina elektrofizioloğisko stabilitāti gan miera stāvoklī, gan palielinātas slodzes apstākḷıs (Mitchell, 1953). Sirds inervācijas izmaiṇas palielina ḷaundabīgu aritmiju un pēkšṇas kardiālas nāves risku, tādēḷ šobrīd ir ḷoti aktuāli atrast sirds inervācijas vizualizācijas metodes, ko varētu izmatot klīniskajā praksē, lai paredzētu aritmiju risku un izvēlētos atbilstošu ārstēšanas metodi (Huang, Boyle and Vaseghi, 2017; Travin, 2017). Lai izvērtētu klīniskajā praksē pieejamās sirds inervācijas vizualizācijas metodes, ir svarīgi izprast izmaiņas dažādu sirds slimību gadījumos.

Lielākajā dạ̣ā mūsu pētîjuma labā priekškambara audu paraugu novērojām bagātīgu inervāciju - daudz līdz ḷoti daudz PGP 9.5 saturošu nervu šḳiedru. Lai arī to relatīvais daudzums statistiski neatšķīās starp grupām, tomēr atsevišḳiem KSS pacientiem labā priekškambara audu paraugos bija tikai maz līdz vidēji daudz PGP 9.5 saturošu nervu šķiedru. Ṇemot vērā literatūras datus (Dae et al., 1995), tas varētu būt saistīts ar hronisku išēmiju, taču, salīdzinot pacientus grupās ar un bez labās koronārās artērijas bojājuma, nozīmīgu atšķirību PGP 9.5 saturošu nervu šķiedru daudzumā nenovērojām. Jāpiebilst, ka tieši šajā grupā arī konstatējām vidēji ciešu negatīvu korelāciju starp LKSS un PGP 9.5 saturošu nervšķiedru daudzumu labā priekškambara 
audos, bet pacientiem ar palielinātu un normālu labā priekškambara izmēru nozīmīgas atšḳirības PGP 9.5 saturošu nervšķiedru daudzumā nebija.

Viena no biežāk sastopamajām aritmijām ar ievērojamu saslimstības un mirstības risku ir priekškambaru fibrilācija jeb mirdzaritmija (Hindricks et al., 2020). Kā viens no mirdzaritmiju izraisošiem un ietekmējošiem faktoriem literatūrā minētas sirds inervācijas izmaiņas, piemēram, pacientiem ar mirdzaritmiju novēro lielāku simpātiskās nervu šķiedru blīvumu nekā pacientiem ar sinusa ritmu (Nguyen et al., 2009; Scridon, Şerban and Chevalier, 2018). Mūsu pētîjumā neatradām PGP 9.5 saturošas labā priekškambara audu inervācijas atšķirības pacientiem ar mirdzaritmiju un pacientiem, kuriem mirdzaritmiju nekonstatēja.

Mūsu pētījuma pacientiem ar KSS novērojām statistiski nozīmīgu, vidēji ciešu negatīvu korelāciju starp PGP 9.5 saturošu nervu šķiedru relatīvo daudzumu un Il-10, $\beta$ D2 un $\beta \mathrm{D} 3$ pozitīvo šūnu relatīvo daudzumu labā priekškambara audos. Il-10 ir spēcīgs pretiekaisuma citokīns, bet $\beta \mathrm{D} 2$ un $\beta \mathrm{D} 3$ antimikrobie peptīdi, tādēl jādomā, ka PGP 9.5 saturošās inervācijas blīvumu ietekmē iekaisuma process labā priekškambara audos. Dz̄̄vnieku pētījumos novērots, ka lokāla simpātiska denervācija samazina iekaisuma šūnu (makrofāgi, neitrofilie un T šūnas) infiltrāciju pēc miokarda infarkta, pasargājot no miokarda hipertrofijas un saglabājot sirds muskuḷa funkciju (Ziegler et al., 2018).

\section{3. Ātriju nātrijurētiskais peptīds (ANUP)}

Ātriju nātrijurētiskais peptīds (ANUP) ir labi zināms sirds mazspējas marḳieris, kura līmenis asin̄̄s gan korelē ar simptomātiskas sirds mazspējas smaguma pakāpi, gan arī ir paaugstināts asimptomātiskas kreisā kambara disfunkcijas gadījumā (Volpe, Carnovali and Mastromarino, 2016; Cannone et al., 2019). Visiem mūsu pētījuma iegūto sirdskaišu pacientiem novērojām sastrēguma pazīmes - vismaz vidēji daudz ANUP pozitīvu kardiomiocītu labā priekškambara audos. Turklāt, tā kā mūsu pētījumā pacientiem ar iegūtām sirdskaitēm bija statistiski nozīmīgi vairāk ANUP pozitīvu kardiomiocītu labā priekškambara audos nekā kontroles grupai jeb pacientiem ar iedzimtām sirdskaitēm, varam spriest, ka pacienti ar iedzimtām sirdskaitēm operēti labāk kompensētā stāvoklī.

Tā kā ANUP un smadzeṇu jeb B tipa nātrijurētisko peptīidu (BNP) kardiomiocīiti sintezē un izdala līdzīgos apstākḷos, atbildot uz miokarda iestiepumu (Nakagawa, Nishikimi and Kuwahara, 2019), likumsakarīgi, ka novērojām ciešu pozitīvu korelāciju starp ANUP pozitīvo kardiomiocītu relatīvo daudzumu labā priekškambara audu paraugos un pacientu BNP līmeni asinīs. 
Vēl viens nozīmīgs faktors, kas potencē ANUP izdalīšanos, ir hipoksija (Baertschi et al., 1986). Gan hipoksijas, gan mehāniska iestiepuma izraisītu ANUP sekrēciju nodrošina un pastiprina lokāli producēts endotelīns (ET-1) (Skvorak, Nazian and Dietz, 1995; Skvorak et al., 1996). KSS grupā novērojām vidēji ciešu pozitīvu korelāciju starp ET-1 pozitīvo endotēlija šūnu relatīvo daudzumu labā priekškambara asinsvados un ANUP pozitīvo kardiomiocītu daudzumu. Tā kā ANUP un ET-1 piemīt pretēji darbības efekti - ANUP izraisa vazodilatāciju, bet ET-1 ir spēcīgs vazokonstriktors -, ANUP nodrošina homeostāzi, izraisot sirds asinsvadu paplašināšanos un uzlabojot skābekḷa piegādi (Barton and Yanagisawa, 2008; Cannone et al., 2019).

Pacientiem ar KSS, bet ne pacientiem ar AoV stenozi novērojām vidēji ciešu pozitīvu korelāciju starp vecumu un ANUP pozitīvo kardiomiocītu daudzumu sirds labajā priekškambarī. Līdzīga tendence novērota arī veseliem cilvēkiem un pacientiem ar sirds mazspēju, taču, tā kā izmaiņas nav pietiekami lielas, referento intervālu indeksācija pēc vecuma klīniskajā praksē netiek lietota (Clerico et al., 2002; Hogenhuis et al., 2005).

\subsection{Asinsvadu endotēlija augšanas faktors (VEGF)}

VEGF organismā nepieciešams normāliem fiziologiskiem procesiem, kur tas piedalās endotēlija funkcijas uzturēšanā, taču izmainīta VEGF sekrēcija novērojama dažādu saslimšanu patoǵenēzē (Laakkonen et al., 2019). Galvenais faktors, kas pastiprina VEGF sekrēciju endotēlija šūnās, ir hipoksija (Namiki et al., 1995). Mūsu pētījumā VEGF pozitīvo endotēlija šūnu relatîvais daudzums visās pētījuma grupās bija ḷoti variabls - sākot no to trūkuma un beidzot ar ḷoti daudz VEGF pozitīvām endotēlija šūnām, turklāt nebija statistiski nozīmīgas atšḳirības grupās. Tātad VEGF sekrēcija labā priekškambara endotēlija šūnās nav specifiski raksturīga nevienai no pētījumā apskatītajām saslimšanām, bet gan variē pacientiem individuāli.

KSS grupā konstatējām vidēji ciešas pozitīvas korelācijas starp VEGF pozitīvo endokarda endotēlija šūnu relatīvo daudzumu un Il-10 un $\beta$ D3 pozitīvo endokarda endotēlija šūnu daudzumu. Ir labi zināms, ka hipoksija izraisa iekaisuma rekciju, taču arī iekaisuma process var izraisīt lokālu hipoksiju, ja, palielinoties metabolai aktivitātei, tiek pārsniegta skābekḷa pieejamība (Ramakrishnan, Anand and Roy, 2014; Takahashi, 2015). Turklāt, piemēram, audzēju gadījumos VEGF izraisa Il-10 produkciju, tādā veidā nomācot iekaisuma procesu (Shin et al., 2009). 
Interesanti, ka pacientiem ar AoV stenozi un lielāku VEGF pozitīvo endotēlija šūnu relatīvo daudzumu labā priekškambara asinsvados novērojām arī lielāku labā priekškambara kardiomiocītu apoptozes indeksu. Pretēju situāciju novēroja līdzīgā dzīvnieku modelī miokarda hipertrofijas gadījumā VEGF pasargā no kardiomiocītu apoptozes, saglabājos sirds kontraktilo funkciju (Friehs et al., 2006). Arī no citiem pētījumiem zināms, ka VEGF pasargā endotēlija šūnas no apoptozes un veicina angioǵenēzi, kā arī pasargā no išēmijas/reperfūzijas radītā bojājuma, kavējot kardiomiocītu apoptozi (Mabeta, 2013; Chen et al., 2016).

\subsection{Hromogranīns A (ChgA)}

ChgA ir neiroendokrīnās sistēmas marḳieris, kas ir paaugstināts neiroendokrīno audzēju un citu saslimšanu, tai skaitā sirds mazspējas un hipertensijas, gadījumos (Mahata and Corti, 2019). Sirds mazspējas gadījumā neiroendokrīnās sistēmas aktivācija ir aizsargmehānisms, kas izraisa vazokonstrikciju, uzturot asinsspiedienu, un palīdz saglabāt sirds izsviedi, palielinot miokarda saraušanās spēku un ātrumu (Kjær and Hesse, 2001). Sākotnēji šādas izmaiņas palīdz saglabāt organismam svarīgās vitālās funkcijas, bet ilgtermiṇā izraisa dekompensāciju. Mūsu pêtījumā statistiski nozīmīgi vairāk ChgA pozitīvu šūnu bija kontroles grupā jeb paraugos no pacientiem ar agrīni operētām iedzimtām sirdskaitēm. Arī lielā daḷā paraugu no pacientiem ar iegūtām sirdskaitēm bija atrodamas ChgA pozitīvas šūnas, taču to relatīvais daudzums paraugos bija ḷoti variabls un nozīmīgu atškirīību starp KSS un AoV stenozes grupu nekonstatējām.

Sirdī ChgA tiek uzglabāts kopā ar nātrijurētiskajiem peptīdiem, un, tāpat kā paaugstināts nātrijurētisko peptīdu līmenis asinīs, arī paaugstināts ChgA līmenis ir saistīts ar palielinātu mirstību un atkārtotām hospitalizācijām sirds mazspējas dekompensācijas un miokarda infarkta dēḷ (Goetze et al., 2013). Jāatzīmēe, ka mūsu pētījumā statistiski nozīmīgas korelācijas starp nātrijurētiskajiem peptīdiem, kreisā kambara izsviedes frakciju un ChgA pozitīvo šūnu relatīvo daudzumu labā priekškambara audos nenovērojām.

Palielināts ChgA līmenis asin̄̄s ir saistīts ar augstu mirstību arī kritiski slimiem intensīvās terapijas un septiskiem pacientiem (Zhang et al., 2009; Hsu et al., 2015). Lai arī vienam no ChgA šḳelšanas galaproduktiem catestatīnam piemīt pretiekaisuma darbība, tomēr pārējiem bioloǵiski aktīviem peptīdiem, ko iegūst, šķeḷot ChgA, ir iekaisumu veicinoša iedarbība (Muntjewerff et al., 2018). KSS grupā novērojām vidēji ciešu pozitīvu korelāciju gan starp ChgA pozitīvo šūnu relatīvo daudzumu un iekaisuma citokīna Il-1 $\alpha$ pozitīvo šūnu relatīvo daudzumu, gan starp ChgA pozitīvo šūnu relatīvo daudzumu un pretiekaisuma citokīna Il-10 pozitīvo šūnu relatīvo daudzumu. Turklāt vidēji cieša pozitīva korelācija šajā grupā bija arī starp ChgA un beta defensīnu pozitīvo šūnu relatīvo daudzumu. Tādējādi varam spriest, ka 
pacientiem ar KSS un izteiktāku pretiekaisuma procesu ir lielāka neiroendokrīnās sistēmas aktivācija.

Vēl viena tendence, ko novērojām KSS grupas pacientiem, bija vidēji cieša pozitīva korelācija starp VEGF pozitīvo un ChgA pozitīvo endokarda endotēlija šūnu relatīvo daudzumu. ChgA fragments vazostatīns var nomākt TNF $\alpha$ un VEGF izraisītas endotēlija šūnu formas un barjeras funkcijas izmaiņas, novēršot asinsvadu caurlaidības palielināšanos, kas ir svarīgi audzēju patoǵenēzē un terapijas efektivitātē (Ferrero et al., 2004). Palielināts ChgA līmenis asinīs kavē medikamentu iekḷūšanu audzēju audos (Loh et al., 2012).

AoV stenozes grupā konstatējām vidēji ciešu negatīvu korelāciju starp apoptozes skarto kardiomiocītu relatīvo daudzumu un ChgA pozitīvo šūnu relatīvo daudzumu labā priekškambara audos. Lai arī ChgA var stimulēt dažādu šūnu apoptozi, piemēram, prostatas karcinomas šūnu apoptozi vai mikroglijas un neironu apoptozi Alcheimera slimības pacientiem (Kingham and Pocock, 2000; Yu, Hsieh and Chang, 2003), tomēr no citiem pētījumiem zināms, ka ChgA pasargā kardiomiocītus no ķīmijterapijas preparāta doksorubicīna izraisītas kardiomiocītu apoptozes (Rocca et al., 2019), bet ChgA fragments catestatīns pasargā hipertrofētu miokardu no išēmijas/reperfūzijas izraisītas kardiomiocītu apoptozes (Penna et al., 2014). N̦emot vērā mūsu pētījuma rezultātus un literatūrā pieejamos datus par ChgA ietekmi uz kardiomiocītu apoptozi, varam secināt, ka ChgA un tā derivātiem piemīt kardioprotektīva iedarbība.

\subsection{Endotelīns 1 (ET-1)}

Palielināta spēcīgā vazokonstriktora ET-1 produkcija ir raksturīga endotēlija disfunkcijas pazīme, savukārt endotēlija disfunkcija ir pamatmehānisms aterosklerozes, kā arī iesaistīta deǵeneratīva AoV stenozes patoǵenēzē (Akahori et al., 2018; Persic et al., 2018; Miyauchi and Sakai, 2019). Mūsu pētījumā KSS un AoV stenozes grupās novērojām dažādu ET-1 pozitīvo endotēlija šūnu relatīvo daudzumu, taču, lai arī atšķkirība nesasniedza statistisku nozīmību, kontroles grupas audos bija mazāk ET-1 pozitīvu endotēlija šūnu. ET-1 uz kardiomiocītiem darbojas parakrīnā ceḷā, tūlītēji palielinot asinsvadu gludās muskulatūras un miokarda kontraktilitāti, kas ilgtermiņā izraisa kardiomiocītu bojājumu un veicina sirds mazspējas progresu (Meyer et al., 1996; Miyauchi and Sakai, 2019). Interesanti, ka tieši labajā priekškambarī ET-1 vispirms izraisa pārejošu negatīvu inotropu efektu, kam seko ilgstoša pozitīva inotropa reakcija (Dhein et al., 2000). Vēl viens nozīmīgs ET-1 efekts uz miokardu ir pārmērīga kardiomiocītu hipertrofija (Ito et al., 1994). Tātad palielināta ET-1 produkcija 
sākotnēji palīdz saglabāt organismam svarīgās vitālās funkcijas, bet ilgtermiṇā izraisa dekompensāciju.

Pacientiem ar AoV stenozi novērojām ciešu pozitīvu korelāciju starp ET-1 pozitīvo un VEGF pozitīvo labā priekškambara endokarda endotēlija šūnu relatīvo daudzumu. VEGF un ET-1 stimulē viens otra sekrēciju, bet VEGF inhibēšana audzēju ārstēšanas procesā izraisa ET- 1 līmeņa paaugstināšanos un arteriālu hipertensiju (Matsuura et al., 1998; Lankhorst, Danser and Meiracker, 2016). Turklāt ET-1 izraisītā izteiktā vazokonstrikcija miokarda asinsvados var samazināt skābekḷa piegādi, kam seko VEGF produkcijas palielināšanās. Savukārt hipoksija, līdzīgi VEGF, var izraisīt arī ET-1 pastiprinātu veidošanos ar hipoksiju izraisošā faktora starpniecību (Heyman, Khamaisi and Abassi, 2018).

Mūsdienās nevienam nav šaubu par ET-1 nozīmi pulmonālas hipertensijas patoǵenēzē (Shao, Park and Wort, 2011), tāpēc interesanti, ka šajā pētījumā novērojām pretēju tendenci statistiski nozīmīgu vidēji ciešu negatīvu korelāciju starp ET-1 pozitīvo endotēlija šūnu relatīvo daudzumu labā priekškambara audos pacientiem ar iegūtām sirdskaitēm ar palielinātu labā kambara sistolisko spiedienu (LKSS). Līdzīga aina konstatēta arī iepriekš - pacientiem ar primāru pulmonālu hipertensiju bija daudz ET-1 pozitīvu šūnu plaušu asinsvados, bet maz vai nemaz miokardā (Giaid et al., 1993). Turklāt šajā pašā pêtījumā novēroja, ka pacientiem ar primāru pulmonālu hipertensiju bija vairāk ET-1 pozitīvu šūnu plaušu asinsvados nekā pacientiem ar sekundāru pulmonālu hipertensiju un to daudzums korelēja ar slimības smaguma pakāpi. Tātad ET-1 produkcijai labā priekškambara audos nav pārliecinošas saistības ar pulmonālu hipertensiju, bet gan ar pamatsaslimšanu.

Vairāki eksperimentāli pētījumi ir saistījuši ET-1 arī ar iekaisuma procesiem, piemēram, pelēm ar lielāku ET-1 līmeni novēroja smagākas pakāpes encefalomielītu un augstāku iekaisuma citokīnu interleikīnu 6 un 17, interferona $\gamma$ un TNF $\alpha$ lìmeni (Guo et al., 2014). Savukārt multiplās sklerozes pacientiem netika novērota korelācija starp ET-1 līmeni un plazmas citokīnu (interleikīni 1ß, 2, 4, 5, 6, 10, 12, 13 un TNF $\alpha$ ) līmeni (Rocha et al., 2019). Līdz ar to šobrīd pārliecinošu pierādījumu ET-1 saistībai ar iekaisuma procesiem nav. Mūsu pētījumā pacientiem ar KSS novērojām vidēji ciešu pozitīvu korelāciju starp ET-1 un $\beta$ D3 pozitīvo šūnu daudzumu, bet AoV stenozes grupā bija cieša pozitīva korelācija starp ET-1 un Il-10 pozitīvo šūnu relatīvo daudzumu labā priekškambara audos. Šeit jāpiebilst, ka Il-10 pasargā asinsvadus no ET-1 izraisītas vazokonstrikcijas (Giachini et al., 2009). 
KSS un AoV stenozes gadījumā ET-1 produkcija vairāk raksturīga labā priekškambara endokarda endotēlija šūnās un nav specifiska kādai no pētījumā apskatītajām saslimšanām.

\subsection{Iekaisums}

Iekaisums ir biolog̣iska aizsargreakcija uz audu bojājumu, un tam ir svarīga loma sirds un asinsvadu sistēmas slimību patoǵenēzē, tādēl iekaisuma novēršana ir viena no galvenajām stratēgijāām, gan lai novērstu kardiovaskulāro slimību riska faktorus, gan lai ārstētu jau esošas slimības. Lai tas būtu iespējams, ir maksimāli jāizprot visi iesaistītie patoǵenēzes faktori. Šajā pētījumā mēs noteicām iekaisuma citokīnu interleikīnu $1 \alpha$, pretiekaisuma citokīnu interleikīnu 10, kā arī antimikrobos peptīdus - beta defensīns 2, 3 un 4 labā priekškambara audos pacientiem ar KSS, deǵeneratīvu AoV stenozi un iedzimtām sirdskaitēm (kontroles grupa).

\subsubsection{Iekaisuma šūnu infiltrācija}

Atsevišķiem pacientiem - trim pacientiem ar KSS un vienam pacientam ar deǵeneratīvu AoV stenozi - labā priekškambara epikardā novērojām fokālu iekaisuma šūnu infiltrāciju. Andersens et al. 2016. gadā publicēja pētījumu, kurā $60 \%$ pacientu ar KSS un bez citām zināmām iekaisīgām slimībām labā priekškambara audu paraugos, kas ṇemti koronāro artēriju šuntēšanas operāciju laikā, arī konstatēja fokālu iekaisuma šūnu infiltrāciju (Andersen et al., 2016). Līdzīgi šim pētījumam, arī mūsu pētījumā, kaut gan atšķirība nesasniedza statistisku nozīmīgumu, tomēr pacienti ar iekaisuma šūnu infiltrāciju labā priekškambara epikardā bija vidēji par deviniiem gadiem jaunāki nekā pacienti bez iekaisuma šūnu infiltrācijas. Tā kā literatūrā nav daudz datu par iekaisuma šūnu infiltrāciju epikardā, ir grūti spriest par tās klīnisko nozīmīgumu un saistību ar KSS vai deǵeneratīvas AoV stenozes patoǵenēzi. Iekaisuma šūnu infiltrācija gados jaunākiem pacientiem varētu liecināt par agresīvāku slimības formu, ṇemot vērā, ka ķirurğiska iejaukšanās bijusi nepieciešama agrīnākā vecumā.

No citiem pētījumiem zināms, ka iekaisuma šūnu infiltrācija kambaru miokardā raksturīga pacientiem ar dilatācijas un hipertrofisku kardiomiopātiju, aortālā vārstuḷa stenozi, pēc miokarda infarkta, bet nav raksturīga fiziologiskas kreisā kambara hipertrofijas gadījumā (Hofmann et al., 2012; Laroumanie et al., 2014; Patel et al., 2018). Nesenā dzīvnieku pētījumā tika identificētas iekaisuma šūnas, kas infiltrē sirds audus pēc aortas daḷējas liǵēšanas (modelis atbilst AoV stenozes situācijai), un konstatēts, ka miokardu infiltrē makrofāgi, CD8+ un CD4+ T šūnas, B šūnas, dabīgās galētājšūnas, tuklās šūnas, neitrofilie leikocīti un regulatorās T šūnas, bet epikardā novēroja tikai tuklo šūnu infiltrāciju (Martini et al., 2019). Turklāt līdzīgā dzīvnieku modelī patoloǵiskas kreisā kambara hipertrofijas gadījumā $\mathrm{T}$ šūnu aktivācijas 
nomākšana gan agrīni, gan uzsākta vēlākā laikā, kad slimība jau ir progresējusi, izraisīja pretiekaisuma citokīna Il-10 līmeņa pieaugumu un ievērojami samazināja sirds mazspējas progresu (Kallikourdis et al., 2017). Lai arī mūsu pētījuma audu paraugos fokālus iekaisuma šūnu infiltrācijas perēkḷus miokardā nenovērojām, tomēr jāatzīmē, ka paraugos ar iekaisuma šūnu infiltrāciju epikardā bija statistiski nozīmīgi vairāk Il-10 pozitīvu endotēlija šūnu labā priekškambara asinsvados nekā paraugos bez iekaisuma šūnu infiltrācijas.

\subsubsection{Interleikīns $1 \alpha$}

Citokīns Il-1 $\alpha$ ir svarīgs elements iekaisuma procesos, taču par tā ekspresiju cilvēka sirds audos ir zināms samērā maz. Sirds un asinsvadu sistēmas slimību gadījumos pārsvarā pētīts tā blokādes terapeitiskais efekts (Szekely and Arbel, 2018). Zināms, ka Il-1 $\alpha$ atrodams aterosklerotiskās plātnēs, taču literatūrā neatrodam pārliecinošus datus par Il-1 $\alpha$ klātbūtni deǵeneratīva AoV virās (Jiang et al., 2019). Mūsu pētījumā visās pacientu grupās apmēram trešdaḷai pacientu labā priekškambara audu paraugos Il-1 $\alpha$ pozitīvas šūnas nekonstatējām vispār, bet pārējiem novērojām pārsvarā retas Il-1 $\alpha$ pozitīvas saistaudu šūnas un maz līdz vidēji daudz Il-1 $\alpha$ pozitīvas endokarda endotēlija šūnas. Il-1 $\alpha$ daudzums šūnās stabilā stāvoklī variē atkarībā no to veida, bet šūnās, kas organismā veido barjeras, piemēram, epitēlija un endotēlija šūnās, Il-1 $\alpha$ daudzums ir ievērojami lielāks (Di Paolo and Shayakhmetov, 2016). Arī mūsu pētījuma labā priekškambara audu paraugos novērojām vairāk Il-1 $\alpha$ pozitīvu endokarda endotēlija šūnu nekā Il-1 $\alpha$ pozitīvu saistaudu šūnu.

Vairākos pētījumos Il-1 $\alpha$ mRNS nav atrasts ne veselas, ne arī dilatācijas kardiomiopātijas un vīrusu izraisīta iekaisuma skartas pieauguša cilvēka sirds muskuḷa šūnās, bet dzīvnieku pētījumos Il-1 $\alpha$ atrodams arī kardiomiocītos (Han et al., 1991; Westphal et al., 2007). Pēc miokarda infarkta vērojams palielināts Il-1 $\alpha$ daudzums kardiomiocītu nekrozes zonā, kur tas iniciē sterilu iekaisuma procesu, līdz ar to tā blokāde samazina infarkta apjomu, kā arī pasargā kreisā kambara funkciju (Timmers et al., 2008; Lugrin et al., 2015; Mauro et al., 2017).

Mūsu pētījumā AoV stenozes grupā konstatējām vidēji ciešu negatīvu korelāciju starp Il-1 $\alpha$ pozitīvo labā priekškambara endokarda endotēlija šūnu relatīvo daudzumu un labā kambara sistolisko spiedienu (LKSS). LKSS atspoguḷo pulmonālas hipertensijas pakāpi un pieaug, pakāpeniski dekompensējoties AoV stenozei, tādēl pacientiem ar palielinātu LKSS ir lielāks AoV stenozes ķirurğiskās ārstēšanas risks (Lancellotti et al., 2012; Cavender and Kolarczyk, 2019). Pacientiem ar plaušu artēriju hipertensiju ir novērots palielināts iekaisuma

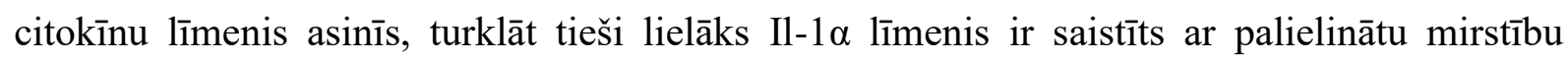


(Cracowski et al., 2014; Rabinovitch et al., 2014). Tā kā KSS grupā šādu saistību nenovērojām un abās iegūto sirdskaišu grupās bija maz pacientu ar palielinātu LKSS, iespējams, nepieciešami papildu pētījumi ar lielāku pacientu skaitu, lai noskaidrotu palielināta labā kambara spiediena ietekmi uz Il-1 $\alpha$ ekspresiju labā priekškambara audos pacientiem ar dekompensētu AoV stenozi.

\subsubsection{Interleikīns 10}

Mūsu pētījumā labā priekškambara audu paraugos Il-10 pozitīvo kardiomiocītu un endokarda endotēlija šūnu bija pārliecinoši vairāk KSS grupā, bet, salīdzinot abas iegūto sirdskaišu grupas ar kontroles grupu, bija atšķirīgs visu apskatīto Il-10 pozitīvo šūnu grupu relatīvais daudzums. Tas norāda, ka palielināta Il-10 produkcija labā priekškambara audos vairāk raksturīga pacientiem ar KSS.

Il-10 ir galvenais pretiekaisuma citokīns, kas nodrošina organisma aizsardzību pārmērīgai iekaisuma reakcijai, galvenokārt inhibējot iekaisuma citokīnu produkciju (Saraiva et al., 2020). Dzīvnieku modeḷos Il-10 gēna delēcija palielina iekaisuma citokīnu līmeni miokardā, kā arī palielina infarkta lielumu un mirstību (Yang, Zingarelli and Szabó, 2000; Meador et al., 2008). Tomēr Il-1 $\alpha$ izraisītu citu iekaisuma citokīnu, piemēram, interleikīna $1 \beta$, TNF $\alpha$ un interleikīna 6, produkciju sirds miofibroblastos tas neietekmē (Turner et al., 2009). Mūsu pētījuma labā priekškambara audu paraugos Il-10 pozitīvo šūnu bija pārliecinoši vairāk kā Il-1 $\alpha$ pozitīvo šūnu, norādot uz pretiekaisuma procesu pārākumu.

Taču Il-10 ietekme nav viennozīmīga, tādēḷ jāpiemin arī Il-10 negatīvais efekts uz miokardu - Il-10 veicina osteopontīna un augšanas faktora beta produkciju sirds makrofāgos, kas aktivē kolagēna sintēzi fibroblastos, kā rezultātā attīstās fibroze un diastoliska mazspēja (Hulsmans et al., 2018). Šajā pētījumā diastoliskās mazspējas parametrus neizvērtējām, taču jāatzīmē, ka konstatējām vidēji ciešu pozitīvu korelāciju starp Il-10 pozitīvo endotēlija šūnu relatīvo daudzumu un labā kambara sistolisko spiedienu, kā arī vidēji ciešu negatīvu korelāciju starp Il-10 pozitīivo endokarda endotēlija šūnu relatīvo daudzumu un kreisā kambara izsviedes frakciju. Tas nozīmē vairāk Il-10 pozitīvu endotēlija šūnu pacientiem ar sliktāku pirmsoperācijas stāvokli - zemāku kreisā kambara izsviedes frakciju un lielāku pulmonālo spiedienu. Lai arī pētījumā par kreisā kambara remodelāciju pacientiem pēc miokarda infarkta Il-10 līmenis asin̄̄s nekorelēja ar izsviedes frakcijas izmaiṇām, tomēr tika konstatēta nozīmīga negatīva korelācija starp Il-10 līmeni un kreisā kambara beigu diastoles diametru 30 dienas pēc miokarda infarkta (Zarrouk-Mahjoub et al., 2016), kas liecina par Il-10 pozitīvo saistību ar kreisā kambara atjaunošanos pēc miokarda infarkta. Savukārt citā pētījumā pacientiem ar 
sistolisku sirds mazspēju un paaugstinātu Il-10 līmeni asin̄̄s tika novērota lielāka mirstîba (Amir et al., 2010).

Vecums ir neatkarīgs riska faktors gan KSS, gan deǵeneratīvas AoV stenozes patoǵenēzē (Baumgartner et al., 2017; Knuuti et al., 2019). Mūsu pêtījuma KSS grupā novērojām vidēji ciešu pozitīvu korelāciju starp Il-10 pozitīvo kardiomiocītu relatīvo daudzumu un pacientu vecumu. Pētījumi par vecuma ietekmi uz Il-10 produkciju ir pretrunīgi (Kelly et al., 2007; Zhang et al., 2015), taču zināms, ka Il-10 pasargā asinsvadus no vecuma izraisītas endotēlija disfunkcijas, kas ir viens no galvenajiem patoǵenēzes elementiem KSS attīstībā (Kinzenbaw et al., 2013; Rajendran et al., 2013).

Vēl viens būtisks sirds asinsvadu slimību riska faktors ir mainīta holesterīna vielmaiņa. Lai arī paaugstinātam triglicerīdu līmenim ir vājāka saistība ar sirds slimību risku nekā hiperholesterinēmijai, tas tomēr ir nozīmīgs neatkarīgs kardiovaskulāro slimību riska faktors (Piepoli et al., 2016). Šajā pētījumā konstatējām vidēji ciešu negatīivu korelāciju starp Il-10 pozitīvo kardiomiocītu relatīvo daudzumu labā priekškambara audos un triglicerīdu līmeni. Citas būtiskas saistības starp Il-10 pozitīvo šūnu relatīvo daudzumu un citām holesterīna frakcijām nekonstatējām. Lai arī Il-10 nav būtiskas ietekmes uz holesterīna līmeni asins cirkulācijā, tas ietekmē makrofāgu holesterīna metabolismu, stimulējot holesterīna uzṇemšanu no lipoproteīniem, kā arī holesterīna izvadi no makrofāgiem (Han et al., 2010). Tomēr pārlieku liels Il-10 līmenis dažu limfoproliferatīvu slimību gadījumā var izraisīt augsta un zema blīvuma holesterīna līmeṇa pazemināšanos un triglicerīdu līmeṇa paaugstināšanos (Moraitis et al., 2015; Lucero et al., 2020).

Šajā pētījumā konstatējām vidēji ciešu statistiski nozīmīgu negatīvu korelāciju starp Il- 10 pozitīvo endotēlija šūnu relatīvo daudzumu labā priekškambara asinsvados un C reaktīvā olbaltuma (CRO) līmeni asinīs. CRO ir akūtās fāzes proteīns, kura līmenis paaugstinās, reaǵējot uz iekaisumu (Pepys and Hirschfield, 2003). Līdzīga situācija - samazināts Il-10 līmenis un palielināts CRO līmenis - novērota pacientiem ar akūtu koronāru sindromu un sirds mazspēju (Stumpf et al., 2003; van Haelst et al., 2004). Šo atradni izskaidro fakts, ka CRO samazina gan Il-10 mRNS, gan intracelulāro Il-10, gan arī Il-10 sekrēciju makrofāgos, inhibējot adenilātciklāzes aktivitāti (Singh et al., 2006).

\subsection{Beta defensīni}

Vispārsteidzošākais atklājums mūsu pētîjumā bija bagātīgā antimikrobo peptīdu atradne labā priekškambara audos gan pacientiem ar KSS, gan pacientiem ar deǵeneratīvu AoV stenozi, gan pacientiem ar iedzimtām sirdskaitēm jeb kontroles grupā. 
Beta defensīni ir antimikrobie peptīdi, kas ir daḷa no aizsardzības mehānisma pret bakteriālām infekcijām. $\beta \mathrm{D} 2$ un $\beta \mathrm{D} 3$ produkciju šūnās var stimulēt bakteriāla infekcija un iekaisuma citokīni, piemēram, Il-1 $\alpha$, Il-1 $\beta$, TNF $\alpha$, interferons $\gamma$ un citi (Harder et al., 1997, 2001; Hiratsuka et al., 1998; Singh et al., 1998; O’Neil et al., 1999; Liu et al., 2002; Pazgier et al., 2006). Turklāt, piemēram, $\beta \mathrm{D} 2$ koncentrācija ir atkarīga no infekcijas stadijas - aktīvajā fāzē ir augsta $\beta D 2$ koncentrācija, kas pakāpeniski normalizējas atveseḷošanās procesā (Yanagi et al., 2007). Literatūrā atrodami vairāki pētījumi par baktēriju un vīrusu lomu gan aterosklerotisku pangu veidošanas procesā, gan tās nestabilitātē (McKechnie and Rubenfire, 2002). Lai arī aterosklerozes skartu asinsvadu sienās ir atrastas baktērijas un vīrusi, tiešu pierādījumu, ka infekcija izraisa aterosklerozi nav, taču nozīme varētu būt hroniskas infekcijas izraisītai iekaisuma reakcijai (Kuo et al., 1993; Chiu et al., 1997). Par to liecina arī vairāki pētījumi, kuros konstatēta palielināta iekaisuma akūtās fāzes marķiera CRO saistība ar kardiovaskulāriem notikumiem (Koenig et al., 1999; Kaptoge et al., 2012). Turklāt pacientiem ar periodontālu infekciju vai palielinātu antivielu līmeni dažādām hroniskām infekcijām, piemēram, 1. tipa herpes simplex vīrusu un Chlamydia pneumoniae, ir lielāks KSS attīstības risks (Roivainen et al., 2000; Dietrich et al., 2008). Jāatzīmē, ka, tāpat kā aterosklerozes gadījumā, stenotisku aortālo vārstuḷu virās ir atrastas Chlamydia pneumoniae un pacientiem ar augstu antivielu titru pret Chlamydia pneumoniae deǵeneratīvu AoV stenozi novēro biežāk un tā ir smagākas pakāpes (Pierri et al., 2006; Turgeman et al., 2006). Par infekcijas iespējamo nozīmi KSS un deǵeneratīva AoV stenozes attīstībā varētu liecināt arī bagātīgā $\beta D 2$ un $\beta D 3$ pozitīvo šūnu atradne visos mūsu pētījuma paraugos un tas, ka konstatējām statistiski nozīmīgu vidēji ciešu pozitīvu korelāciju starp $\beta \mathrm{D} 3$ pozitīvo kardiomiocītu relatīvo daudzumu paraugos, kas ņemti no pacientiem ar iegūtām sirdskaitēm, un CRO līmeni asin̄̄s. KSS grupā novērojām vidēji ciešu pozitīvu korelāciju starp Il-1 $\alpha$ pozitīvo endokarda endotēlija šūnu un $\beta$ D3 pozitīvo kardiomiocītu un saistaudu šūnu relatīvo daudzumu labā priekškambara audos, kas parāda iekaisuma procesu lokāli labā priekškambara audos un, iespējams, saistīts ar Il-1 $\alpha$ spēju stimulēt šūnas producēt beta defensīnus.

Jāpiebilst, ka $\beta \mathrm{D} 2$ inducē iekaisuma citokīna interleikīna 6 un hemokīna 8, kā arī pretiekaisuma citokīna Il-10 produkciju (Boniotto et al., 2006). Šajā pašā pētījumā $\beta D 3$ šāda īpašība netika novērota. Mūsu pētîjumā novērojām vidēji ciešu un ciešu korelāciju starp Il-10 pozitīvo saistaudu šūnu un $\beta$ D2 un $\beta$ D3 pozitīvo kardiomiocītu un saistaudu relatīvo daudzumu labā priekškambara audos. 
Interesanti, ka visās pētījuma grupās novērojām statistiski ticamu vidēji ciešu korelāciju starp $\beta$ D2 pozitīvo šūnu skaitu un pacientu vecumu, bet ar $\beta$ D3 pozitīvo šūnu skaitu šādu saistību nenovērojām. Tas varētu liecināt par KSS un deǵeneratīva AoV stenozes pacientu vecuma ietekmi uz šūnu spēju producēt $\beta \mathrm{D} 2$, bet ne $\beta \mathrm{D} 3$. Novērojot gados vecākus veselus cilvēkus, secināts, ka šūnu spēja producēt $\beta \mathrm{D} 2$ ir līdzīga jauniem cilvēkiem, bet, piemēram, novecojošā ādā novērots samazināts $\beta D 3$ daudzums (Castañeda-Delgado et al., 2013; Pilkington et al., 2018).

Vēl viens sirds un asinsvadu sistēmas slimību riska faktors ir dislipidēmija (Mach et al., 2020). Abās iegūto sirdskaišu grupās - gan pacientiem ar KSS, gan pacientiem ar deǵeneratīvu AoV stenozi - novērojām vidēji ciešu vai ciešu negatīvu korelāciju starp $\beta \mathrm{D} 2$ un $\beta \mathrm{D} 3$ pozitīvo šūnu daudzumu labā priekškambara audos un kopējā vai zema blīvuma holesterīna (ZBLH) līmeni asinīs. Līdzīga tendence novērota starp alfa defensīniem un seruma kopējo un zema blīvuma holesterīnu (López-Bermejo et al., 2007). Kā viens no skaidrojošiem mehānismiem varētu būt alfa defensīnu spēja saistīties ar ZBLH receptoriem, tādā veidā konkurējot un kavējot ZBLH saistīšanos (Higazi et al., 2000). Par beta defensīniem literatūrā šādus datus neatrodam, tādēḷ nepieciešami papildu pētījumi, lai izvērtētu beta defensīnu un holesterīna frakciju saistību.

Šajā pētījumā KSS grupā konstatējām statistiski nozīmīgu ciešu korelāciju starp $\beta \mathrm{D} 2$ un ßD3 pozitīvo kardiomiocītu daudzumu un smadzeṇu nātrijurētiskā peptīda (BNP) līmeni asin̄̄s, kā arī nozīmīgu vidēji ciešu korelāciju starp $\beta$ D2 pozitīvo endotēlija šūnu daudzumu un ANUP pozitīvo kardiomiocītu daudzumu. BNP un ANUP ir peptīdi, ko producē kardiomiocīti, reaǵējot uz palielinātu mehānisko slodzi un sienas iestiepumu (Nakagawa, Nishikimi and Kuwahara, 2019). Klīniskajā praksē BNP līmeni asin̄̄s izmanto, lai izvērtētu sirds mazspējas dekompensāciju un lietotās terapijas efektivitāti (Ponikowski et al., 2016).

Rādītājs, kas tiešā veidā parāda palielinātu spiedienu sirds labajā kambarī un atspoguḷo spiedienu plaušu artērijās, ir labā kambara sistoliskais spiediens (LKSS) (Thibodeau and Drazner, 2018). Interesanti, ka pacientiem ar KSS novērojām statistiski nozīmīgu vidēji ciešu pozitīvu korelāciju starp LKSS un Il-10, $\beta$ D2 un $\beta$ D3 pozitīvo šūnu relatīvo daudzumu labā priekškambara audos un vidēji ciešu negatīvu korelāciju starp LKSS un PGP 9.5 pozitīvo nervšķiedru un VEGF pozitīvo endotēlija šūnu relatīvo daudzumu labā priekškambara audos. Savukārt AoV stenozes grupā novērojām šādu tendenci - vidēji ciešu negatīvu korelāciju starp LKSS un Il-1 $\alpha$ un $\beta$ D2 pozitīvo šūnu relatīvo daudzumu labā priekškambara audos. Palielināts spiediens sirds labās puses dobumos pacientiem ar AoV stenozi parasti ir sekundārs un ir saistīts ar kreisās puses dekompensāciju (Généreux et al., 2017), tādēḷ morfologiiskās izmaiṇas labā priekškambara audos, visdrīzāk, saistītas ar palielinātu spiedienu. KSS gadījumā, ja nav izteikta 
kreisās puses mazspēja, pulmonālai hipertensijai var būt dažādi iemesli, visbiežāk tā ir primāra (Shimony et al., 2011), tādēḷ izmaiṇas labā priekškambara morfologijāā var būt saistītas gan ar KSS, gan ar pulmonālas hipertensijas patoǵenēzes mehānismiem. Tātad pacientiem ar KSS un pulmonālas hipertensijas pazīmēm labā priekškambara audos raksturīga lielāka pretiekaisuma citokīna Il-10 un antimikrobo peptīdu produkcija, bet samazināta inervācija un VEGF produkcija.

Nobeigumā varam teikt, ka labā priekškambara audus gan KSS, gan deǵeneratīvas AoV stenozes gadījumā raksturo nespecifiskas deǵeneratīvas morfologiskas pārmaiņas - izteikta vakuolizācija, kā arī kardiomiocītu un to kodolu formas un izmēra maiņa. Turklāt šiem pacientiem raksturīgs arī liels apoptotisko kardiomiocītu ìpatsvars. Lai gan AoV stenozes pacientiem nebija nozīmīgu bojājumu koronārajās artērijās, atsevišḳiem pacientiem abās pētītajās grupās novērojām saistaudu ieaugšanu un asinsvadu sklerozi.

KSS un deǵeneratīvas AoV stenozes gadījumā notiek labā priekškambara endokarda endotēlija šūnu aktivācija, kam raksturīga formas maiṇa no plakanas uz kubisku un bagātīga ChgA, ET-1, Il-1 $\alpha$, Il-10, $\beta$ D2 un $\beta$ D3 izdale.

Pacientiem ar KSS un AoV stenozi labā priekškambara audos bija statistiski nozīmīgi vairāk ANUP pozitīvu kardiomiocītu, visu veidu Il-10 pozitīvu šūnu un $\beta$ D2 un $\beta$ D3 pozitīvu endokarda endotēlija šūnu, bet mazāk ChgA pozitīvu šūnu nekā kontroles grupā jeb pacientiem ar iedzimtām sirdskaitēm. Tātad abu pētīto iegūto sirdskaišu gadījumā labā priekškambara audos prevalē pretiekaisuma reakcija, bet palielināta neiroendokrīnās sistēmas aktivitāte vairāk raksturīga pacientiem ar iedzimtām sirdskaitēm agrīnā vecumā.

Lai arī novērojām atsevišķas tendences, piemēram, KSS grupā labā priekškambara audos bija nedaudz vairāk VEGF, ET-1, Il-1 $\alpha$ pozitīvu endokarda endotēlija šūnu, Il-10 pozitīvu kardiomiocītu, saistaudu un endotēlija šūnu, bet AoV stenozes grupā - ChgA pozitīvu endokarda endotēlija šūnu, tomēr statistisku nozīmīgumu šīs atšķirības nesasniedza.

Vispārsteidzošākais atklājums mūsu pētījumā bija bagātīgā antimikrobo peptīdu atradne labā priekškambara audos gan pacientiem ar KSS, gan pacientiem ar deǵeneratīvu AoV stenozi, gan pacientiem ar iedzimtām sirdskaitēm jeb kontroles grupā. 


\section{Secinājumi}

1. Gan KSS, gan AoV stenozes pacientu labā priekškambara audus raksturo nespecifiskas morfolog̣iskas pārmaiņas: kodolu formas maiņa un vakuolizācija, kas korelē ar apoptozes atradni kardiomiocītos. Savukārt fokāli iekaisuma perēkḷi raksturīgi gados jauniem iegūtu sirdskaišu pacientiem, un to korelācija ar Il-10 izdali ir specifisks šs̃s grupas pacientu intensificējošs pretiekaisuma reakcijas piemērs.

2. KSS un deǵeneratīvas AoV stenozes gadījumā labā priekškambara endokarda endoteliocīti maina formu no plakanas uz kubisku un bagātīgi izdala ChgA, ET-1, Il-1 $\alpha$, Il-10, $\beta$ D2 un $\beta D 3$, tas liecina par izteiktu šo šūnu plasticitāti nevienmērīgas išēmijas apstākḷos (VEGF variabla palielināšanās).

3. Gan KSS, gan AoV stenozes pacientiem kopumā raksturīga bagātīga labā priekškambara neiropeptīdus saturošo nervškikiedru inervācija. Tās samazināšanās KSS pacientiem ar izteiktāku pretiekaisuma citokīna Il-10 un antimikrobo peptīdu $\beta \mathrm{D} 2$ un $\beta \mathrm{D} 3$ produkciju liecina par kompensatoru nervšḳiedru veidošanās bloḳēšanu iekaisuma apstākḷıs.

4. KSS pacientiem ar palielinātu ET-1 produkciju labā priekškambara audos raksturīga arī lielāka ANUP sekrēcija, kas nodrošina miokarda aizsardzību pret ET-1 nelabvēlīgo ietekmi.

5. Kopumā iegūto sirdskaišu gadījumā VEGF pozitīvo struktūru daudzums labā priekškambara audos variē individuāli. AoV stenozes pacientiem palielinātais VEGF pozitīvo šūnu daudzums korelē ar apoptozes intensifikāciju, bet KSS pacientiem VEGF uzturētā išēmija stimulē lokālo pretiekaisuma faktoru Il-10 un $\beta$ D3 pozitīvo struktūru pieaugumu.

6. Palielināta ChgA produkcija labā priekškambara audos un līdz ar to arī neiroendokrīnās sistēmas aktivitāte vairāk raksturīga pacientiem ar iedzimtām sirdskaitēm agrīnā vecumā. Iegūto sirdskaišu gadījumā variablais ChgA pozitīvo šūnu daudzums korelē galvenokārt ar Il-10, $\beta \mathrm{D} 2$ un $\beta \mathrm{D} 3$, norādot uz pretiekaisuma reakcijas stimulāciju, ko veicina išēmija (korelācija ar VEGF saturošo šūnu skaitu), bet ChgA negatīvā korelācija ar apoptozi pamato faktora kardioprotektîvo lomu.

7. ET-1 saturošo šūnu daudzums KSS un AoV stenozes pacientiem ir individuāli variabls, bet lielāks nekā iedzimto sirdskaišu pacientiem. ET-1 izdala galvenokārt endokarda endoteliocīiti, liecinot tieši par šo šūnu intensīvāku iesaisti faktora ekspresijā.

8. KSS un AoV stenozes pacientu labā priekškambara audus raksturo neizteikta Il-1 $\alpha$ un izteiktāka Il-10 saturošo šūnu klātbūtne, liecinot par korektu iekaisuma/pretiekaisuma citokīnu attiecību īpaši KSS pacientiem. 
9. Iegūto sirdskaišu pacientu labā priekškambara audos novēro palielinātu $\beta \mathrm{D} 2$ un $\beta \mathrm{D} 3$ saturošo šūnu daudzumu, kas korelē ar palielinātu Il-10 un CRO līmeni, liecinot, ka tiek intensificēta visa lokālā aizsardzības sistēma un tā ir saistīta ar atbildes iekaisuma reakciju. Novecošanai piemīt selektīva spēja stimulēt $\beta \mathrm{D} 2$ saturošo šūnu skaita palielināšanos, akcentējot arī deǵeneratīvo procesu nozīmi atsevišşu defensīnu izdalē. Palielināts LKSS ir papildu faktors, kas veicina lokālās pretmikrobās sistēmas aktivāciju. 


\title{
Publikācijas un ziṇojumi par promocijas darba tēmu
}

\author{
Zinātniskās publikācijas izdevumos, kas iekḷauti starptautiskajās datubāzēs \\ (Web of Science, SCOPUS, ERIH PLUS )
}

1. Edīte Vārtinana, Māra Pilmane, Romans Lācis. Homeostasis Regulating Factors, Innervation, Ischemia and Inflammatory Markers in the Right Atrial Tissue from Patients with Degenerative Aortic Valve Stenosis and Coronary Heart Disease. Proceedings of the Latvian Academy of Sciences. Section B. 2021; 75(3): 186.-193. doi: 10.2478/prolas-2021-0028.

2. Edīte Vārtina, Māra Pilmane, Romans Lācis. Inflammatory cytokines and antimicrobial peptides in acquired heart diseases. Histol Histopathol. 2019; 34(8):889-897. doi: 10.14670/HH-18-091.

\section{Zinātniski raksti Latvijā izdotos recenzējamos izdevumos}

1. Edīte Kulmane, Māra Pilmane, Romans Lācis. Apoptosis, ANUP, Chromogranin A, PGP 9.5, Endothelins and VEGF in Acquired Heart Diseases: Review of Literature. Acta Chirurgica Latviensis, 2015; 15(1):63-72.

2. Edīte Kulmane, Māra Pilmane, Romans Lācis. Right Atrial Tissue Morphology in Different Acquired Heart Diseases: a Pilot Study. RSU Research Articles in Medicine and Pharmacy 2014: 70-79.

\section{Uzstāšanās starptautiskās zinātniskajās konferencēs}

1. Edīte Vārtina, Māra Pilmane, Romans Lācis. Common and Different Tissue Factors in the Right Atrial Tissue from Patients with and without Atrial Fibrillation. Rīga Stradiņš University International Conference on Medical and Health Care Sciences. Tēžu grāmata, 2021: 406. (Stenda referāts).

2. Edīte Vārtina, Māra Pilmane, Romans Lācis. Common and Different Homeostasis Regulating Factors, Innervation, Ischemia and Inflammatory Markers in the Right Atrial Tissue from Patients with Degenerative Aortic Valve Stenosis and Coronary Heart Disease. Rīga Stradiņ̌̌ University International Conference on Medical and Health Care Sciences. Tēžu grāmata, 2019: 581. (Stenda referāts).

3. Edīte Vārtiṇa, Māra Pilmane, Emīls Šmitiṇš, Romans Lācis. Homeostasis Regulating Factors, Innervation and Ischemia Markers in the Right Atrial Tissue from Different Acquired and Congenital Heart Diseases. 9th Baltic Morphology Conference, Tartu, Igaunija. Tēžu grāmata, 2017: 93. (Mutiska prezentācija).

4. Edīte Vārtina, Māra Pilmane, Romans Lācis. Distribution of PGP 9.5 Immunoreactive Nerves in Right Atrial Tissue from Patients with Coronary Heart Disease. 26th Nordic-Baltic Congress of Cardiology, 2017, Viḷna, Lietuva. Medicina, 2017; 53(1):67 (Stenda referāts).

5. Edīte Vārtiṇa, Māra Pilmane, Romans Lācis. Morphology of Right Atrial Endocardial Endothelial Cells in Different Acquired Heart Diseases. 12th International Congress of Cell Biology, Prāga, Čehija. Tēžu grāmata, 2016:288. (Stenda referāts).

6. Edīte Kulmane, Māra Pilmane, Romans Lācis. Antiinflammatory Cytokines and Antimicrobial Peptides in Acquired Heart Diseases. 8th Baltic Morphology Scientific Conference, 2015. Vilına, Lietuva. Tēžu grāmata, 2015: 53. (Balva par labāko mutisko prezentāciju).

7. Edīte Kulmane, Māra Pilmane, Romans Lācis. Right Atrial Tissue Morphology in Acquired Heart Diseases. International Conference on Microscopic and Macroscopic Anatomy, Barselona, Spānija. Tēžu grāmata, 2015: 1335. (Mutiska prezentācija). 
8. Edīte Kulmane, Māra Pilmane, Romans Lācis. Chromogranin A Expression in Right Atrial Tissue in Patients with Severe Aortic Valve Stenosis. $25^{\text {th }}$ Nordic-Baltic Congress of Cardiology, Tallina, Igaunija. Cardiology, 2015; 131 (1): 33. (Stenda referāts).

9. Edīte Kulmane, Māra Pilmane, Romans Lācis. Right Atrial Tissue Morphology in Different Acquired Heart Diseases: a Pilot Study. The $64^{\text {th }}$ International Congress of the European Society of Cardiovascular and Endovascular Surgery, Stambula, Turcija. The Journal of Cardiovascular Surgery, 2015; 46 (1-2): 222-223. (Stenda referāts).

\section{Uzstāšanās vietējās nozīmes zinātniskajās konferencēs}

1. Edīte Vārtiņa, Māra Pilmane, Emīls Šmitiņš, Romans Lacis. Homeostāzi regulējošie faktori, inervācijas un išēmijas marķieri labā priekškambara audos iegūtu un iedzimtu sirdskaišu gadījumos. RSU zinātniskās konferences tēzes. 2018:148. (Stenda referāts).

2. Edīte Vārtiṇa, Māra Pilmane, Romans Lācis. PGP 9.5 saturošu nervu škiedru izplatība labā priekškambara audos koronāras sirds slimības pacientiem. RSU zinātniskās konferences tēzes. 2018:149. (Mutiska prezentācija).

3. Edīte Vārtiṇa, Māra Pilmane, Romans Lācis. Labā priekškambara endokarda endotēlija šūnu morfologijija dažādu iegūtu sirdskaišu gadījumos. RSU zinātniskās konferences tēzes. 2017: 187. (Mutiska prezentācija).

4. Edīte Kulmane Māra Pilmane, Romans Lācis. Antibakteriālie peptīdi un pretiekaisuma citokīni dažādu iegūtu sirdskaišu gadījumos. RSU znātniskās konferences tēzes. 2016: 12. (Stenda referāts).

5. Edīte Kulmane, Māra Pilmane, Romans Lācis. Labā priekškambara audu strukturālās izmaiñas dažādu iegūtu sirdskaišu gadījumos. RSU zinātniskās konferences tēzes. 2015: 46. (Stenda referāts) 


\section{Literatūras saraksts}

1. Abbate, A., Biondi-Zoccai, G. G. L., Bussani, R., Dobrina, A., Camilot, D., Feroce, F., Rossiello, R., Baldi, F., Silvestri, F., Biasucci, L. M. and Baldi, A. 2003. Increased myocardial apoptosis in patients with unfavorable left ventricular remodeling and early symptomatic post-infarction heart failure. Journal of the American College of Cardiology, 41(5), 753-760.

2. Abbate, A., Salloum, F. N., Vecile, E., Das, A., Hoke, N. N., Straino, S., Giuseppe, G. L., BiondiZoccai, Houser, J. E., Qureshi, I. Z., Ownby, E. D., Gustini, E., Biasucci, L. M., Severino, A., Capogrossi, M. C., Vetrovec, G. W., Crea, F., Baldi, A., Kukreja, R. C. and Dobrina, A. 2008. Anakinra, a recombinant human interleukin-1 receptor antagonist, inhibits apoptosis in experimental acute myocardial infarction. Circulation, 117(20), 2670-2683.

3. Abbate, A., van Tassell, B. W., Biondi-Zoccai, G., Kontos, M. C., Grizzard, J. D., Spillman, D. W., Oddi, C., Roberts, C. S., Melchior, R. D., Mueller, G. H., Abouzaki, N. A., Rengel, L. R., Varma, A., Gambill, M. L., Falcao, R. A., Voelkel, N. F., Dinarello, C. A. and Vetrovec, G. W. 2013. Interleukin-1 Blockade With Anakinra to Prevent Adverse Cardiac Remodeling After Acute Myocardial Infarction (Virginia Commonwealth University Anakinra Remodeling Trial [VCUART] Pilot Study). American Journal of Cardiology, 111(10), 1394-1400.

4. Agapitov, A. V. and Haynes, W. G. 2002. Role of endothelin in cardiovascular disease. Journal of the Renin-Angiotensin-Aldosterone System, 3(1), 1-15.

5. Ahmed, A., Johansson, O. and Folan-Curran, J. 1997. Distribution of PGP 9.5, TH, NPY, SP and CGRP immunoreactive nerves in the rat and guinea pig atrioventricular valves and chordae tendineae. Journal of Anatomy, 191(4), 547-560.

6. Akahori, H., Tsujino, T., Masuyama, T. and Ishihara, M. 2018. Mechanisms of aortic stenosis. Journal of Cardiology, 71(3), 215-220.

7. Ali, R. S., Falconer, A., Ikram, M., Bissett, C. E., Cerio, R. and Quinn, A. G. 2001. Expression of the peptide antibiotics human $\beta$ defensin-1 and human $\beta$ defensin- 2 in normal human skin. Journal of Investigative Dermatology, 117(1), 106-111.

8. Amir, O., Rogowski, O., David, M., Lahat, N., Wolff, R. and Lewis, B. S. 2010. Circulating interleukin-10: Association with higher mortality in systolic heart failure patients with elevated tumor necrosis factor-alpha. Israel Medical Association Journal, 12(3), 158-162.

9. Andersen, J. K., Oma, I., Prayson, R. A., Kvelstad, I. L., Almdahl, S. M., Fagerland, M. W. and Hollan, I. 2016. Inflammatory cell infiltrates in the heart of patients with coronary artery disease with and without inflammatory rheumatic disease: A biopsy study. Arthritis Research and Therapy, 18(1), 1-10.

10. Armour, J. A. 2008. Potential clinical relevance of the "little brain" on the mammalian heart. Experimental Physiology, 93(2), 165-176.

11. Asahara, T., Bauters, C., Pastore, C., Kearney, M., Rossow, S., Bunting, S., Ferrara, N., Symes, J. F. and Isner, J. M. 1995. Local delivery of vascular endothelial growth factor accelerates reendothelialization and attenuates intimai hyperplasia in balloon-injured rat carotid artery. Circulation, 91(11), 2793-2801.

12. Austin, K. M., Trembley, M. A., Chandler, S. F., Sanders, S. P., Saffitz, J. E., Abrams, D. J. and $\mathrm{Pu}, \mathrm{W}$. T. 2019. Molecular mechanisms of arrhythmogenic cardiomyopathy. In Nature Reviews Cardiology (Vol. 16, Issue 9).

13. Baertschi, A. J., Hausmaninger, C., Walsh, R. S., Mentzer, R. M., Wyatt, D. A. and Pence, R. A. 1986. Hypoxia-induced release of atrial natriuretic factor (ANF) from the isolated rat and rabbit heart. Biochemical and Biophysical Research Communications, 140(1), 427-433.

14. Bals, R. 2000. Epithelial antimicrobial peptides in host defense against infection. Respir Res, 1, 141-150. 
15. Bals, R., Wang, X., Wu, Z., Freeman, T., Bafna, V., Zasloff, M. and Wilson, J. M. 1998. Human $\beta$-defensin 2 is a salt-sensitive peptide antibiotic expressed in human lung. Journal of Clinical Investigation, 102(5), 874-880.

16. Bartolomucci, A., Possenti, R., Mahata, S. K., Fischer-Colbrie, R., Loh, Y. P. and Salton, S. R. J. 2011. The extended granin family: Structure, function and biomedical implications. Endocrine Reviews, 32(6), 755-797.

17. Barton, M. and Yanagisawa, M. 2008. Endothelin: 20 Years from discovery to therapy. Canadian Journal of Physiology and Pharmacology, 86(8), 485-498.

18. Bates, D. O., Hillman, N. J., Williams, B., Neal, C. R. and Pocock, T. M. 2002. Regulation of microvascular permeability by vascular endothelial growth factors. Journal of Anatomy, 200(6), 581-597.

19. Baumgartner, H., Falk, V., Bax, J. J., de Bonis, M., Hamm, C., Holm, P. J., Iung, B., Lancellotti, P., Lansac, E., Muñoz, D. R., Rosenhek, R., Sjögren, J., Tornos Mas, P., Vahanian, A., Walther, T., Wendler, O., Windecker, S., Zamorano, J. L., Roffi, M., Aboyans, V. 2017. 2017 ESC/EACTS Guidelines for the management of valvular heart disease. European Heart Journal, 38(36), 2739-2786.

20. Bauriedel, G., Hutter, R., Welsch, U., Bach, R., Sievert, H. and Lüderitz, B. 1999. Role of smooth muscle cell death in advanced coronary primary lesions: Implications for plaque instability. Cardiovascular Research, 41(2), 480-488.

21. Bellamy, M. F., Pellikka, P. A., Klarich, K. W., Tajik, A. J. and Enriquez-Sarano, M. 2002. Association of cholesterol levels, hydroxymethylglutaryl coenzyme-A reductase inhibitor treatment, and progression of aortic stenosis in the community. Journal of the American College of Cardiology, 40(10), 1723-1730.

22. Ben-Dor, I., Pichard, A. D., Gonzalez, M. A., Weissman, G., Li, Y., Goldstein, S. A., Okubagzi, P., Syed, A. I., Maluenda, G., Collins, S. D., Delhaye, C., Wakabayashi, K., Gaglia, M. A., Torguson, R., Xue, Z., Satler, L. F., Suddath, W. O., Kent, K. M., Lindsay, J. and Waksman, R. 2010. Correlates and causes of death in patients with severe symptomatic aortic stenosis who are not eligible to participate in a clinical trial of transcatheter aortic valve implantation. Circulation, 122(11 SUPPL. 1), 1-13.

23. Bennett, M. R., Sinha, S. and Owens, G. K. 2016. Vascular smooth muscle cells in atherosclerosis. Cirk Res., 118(4), 692-702.

24. Bennett, M. R. 1999. Apoptosis of vascular smooth muscle cells in vascular remodelling and atherosclerotic plaque rupture. Cardiovascular Research, 41(2), 361-368.

25. Birkenfeld, A. L., Boschmann, M., Moro, C., Adams, F., Heusser, K., Franke, G., Berlan, M., Luft, F. C., Lafontan, M. and Jordan, J. 2005. Lipid mobilization with physiological atrial natriuretic peptide concentrations in humans. Journal of Clinical Endocrinology and Metabolism, 90(6), 3622-3628.

26. Black, S., Kushner, I. and Samols, D. 2004. C-reactive protein. Journal of Biological Chemistry, 279(47), 48487-48490.

27. Boniotto, M., Jordan, W. J., Eskdale, J., Tossi, A., Antcheva, N., Crovella, S., Connell, N. D. and Gallagher, G. 2006. Human $\beta$-defensin 2 induces a vigorous cytokine response in peripheral blood mononuclear cells. Antimicrobial Agents and Chemotherapy, 50(4), 1433- 1441.

28. Brandt, R. R., Wright, R. S., Redfield, M. M. and Burnett, J. C. 1993. Atrial natriuretic peptide in heart failure. Journal of the American College of Cardiology, 22(4), 86-92.

29. Brutsaert, D. L., Meulemans, A. L., Sipido, K. R. and Sys, S. U. 1988. Effects of damaging the endocardial surface on the mechanical performance of isolated cardiac muscle. Circulation Research, 62(2), 358-366.

30. Brutsaert, Dirk L. 2003. Cardiac endothelial-myocardial signaling: Its role in cardiac growth, contractile performance, and rhythmicity. Physiological Reviews, 83(1), 59-115. 
31. Bujak, M. and Frangogiannis, N. 2009. The role of Interleukin-1 in the pathogenesis of heart disease. Arch Immunol Ther Exp, 57(3), 165-176.

32. Buschmann, I. and Schaper, W. 1999. Arteriogenesis versus angiogenesis: Two mechanisms of vessel growth. News in Physiological Sciences, 14(3), 121-125.

33. Cai, W. and Schaper, W. 2008. Mechanisms of arteriogenesis. Acta Biochimica et Biophysica Sinica, 40(8), 681-692.

34. Calderone, A., Thaik, C. M., Takahashi, N., Chang, D. L. F. and Colucci, W. S. 1998. Nitric oxide, atrial natriuretic peptide, and cyclic GMP inhibit the growth-promoting effects of norepinephrine in cardiac myocytes and fibroblasts. Journal of Clinical Investigation, 101(4), 812-818.

35. Cannone, V., Cabassi, A., Volpi, R. and Burnett, J. C. 2019. Atrial natriuretic peptide: A molecular target of novel therapeutic approaches to cardio-metabolic disease. International Journal of Molecular Sciences, 20(13), 1-11.

36. Cao, J. M., Fishbein, M. C., Han, J. B., Lai, W. W., Lai, A. C., Wu, T. J., Czer, L., Wolf, P. L., Denton, T. A., Shintaku, I. P., Chen, P. S. and Chen, L. S. 2000. Relationship between regional cardiac hyperinnervation and ventricular arrhythmia. Circulation, 101(16), 1960- 1969.

37. Cao, L. and Gardner, D. G. 1995. Natriuretic peptides inhibit DNA synthesis in cardiac fibroblasts. Hypertension, 25(2), 227-234.

38. Carlsson, A. C., Ruge, T., Kjøller, E., Hilden, J., Kolmos, H. J., Sajadieh, A., Kastrup, J., Jensen, G. B., Larsson, A., Nowak, C., Jakobsen, J. C., Winkel, P., Gluud, C. and Ärnlöv, J. 2018. 10Year associations between tumor necrosis factor receptors 1 and 2 and cardiovascular events in patients with stable coronary heart disease: A CLARICOR (Effect of Clarithromycin on Mortality and Morbidity in Patients with Ischemic Heart Disease) trial s. Journal of the American Heart Association, 7(9), 1-11.

39. Castañeda-Delgado, J. E., Miranda-Castro, N. Y., González-Amaro, R., González-Curiel, I., Montoya-Rosales, A., Rivas-Calderon, B. and Rivas-Santiago, B. 2013. Production of antimicrobial peptides is preserved in aging. Clinical Immunology, 148(2), 198-205.

40. Cavender, M. A. and Kolarczyk, L. 2019. Pulmonary Hypertension and Aortic Stenosis: Further Evidence That TAVR Is Not SAVR. JACC: Cardiovascular Imaging, 12(4), 602-604.

41. Ceconi, C., Ferrari, R., Bachetti, T., Opasich, C., Volterrani, M., Colombo, B., Parrinello, G. and Corti, A. 2002. Chromogranin A in heart failure: A novel neurohumoral factor and a predictor for mortality. European Heart Journal, 23(12), 967-974.

42. Chartier, L., Schiffrin, E., Thibault, G. and Garcia, R. 1984. Atrial natriuretic factor inhibits the stimulation of aldosterone secretion by angiotensin II, acth and potassium In Vitro and angiotensin II-induced steroidogenesis In Vivo. Endocrinology, 115(5), 2026-2028.

43. Chen, J. H. and Simmons, C. A. 2011. Cell-Matrix Interactions in the Pathobiology of Calcific Aortic Valve Disease. Circulation Research, 108(12), 1510-1524.

44. Chen, P. S., Chen, L. S., Cao, J. M., Sharifi, B., Karaguezian, H. S. and Fishbein M. C. 2001. Sympathetic nerve sprouting, electrical remodeling and the mechanisms of sudden cardiac death. Cardiovascular Research, 50(2), 409-416.

45. Chen, X., Lv, Y., Zhao, D., Zhang, L., Zheng, F., Yang, J., Li, X., Wang, L., Guo, L., Pan, Y., Yan, Y., Chen, S., Wang, J., Tang, J. and Wan, Y. 2016. Vascular endothelial growth factor-C protects heart from ischemia/reperfusion injury by inhibiting cardiomyocyte apoptosis. Molecular and Cellular Biochemistry, 413(1-2), 9-23.

46. Chikwe, J., Beddow, E. and Glenville, B. 2006. Extracorporeal circulation. In Cardiothoracic surgery, 99-125. 
47. Chin, C. W. L., Everett, R. J., Kwiecinski, J., Vesey, A. T., Yeung, E., Esson, G., Jenkins, W., Koo, M., Mirsadraee, S., White, A. C., Japp, A. G., Prasad, S. K., Semple, S., Newby, D. E. and Dweck, M. R. 2017. Myocardial Fibrosis and Cardiac Decompensation in Aortic Stenosis. JACC: Cardiovascular Imaging, 10(11), 1320-1333.

48. Chintalgattu, V., Nair, D. M. and Katwa, L. C. 2003. Cardiac myofibroblasts: A novel source of vascular endothelial growth factor (VEGF) and its receptors Flt-1 and KDR. Journal of Molecular and Cellular Cardiology, 35(3), 277-286.

49. Chiong, M., Wang, Z. V., Pedrozo, Z., Cao, D. J., Troncoso, R., Ibacache, M., Criollo, A., Nemchenko, A., Hill, J. A. and Lavandero, S. 2011. Cardiomyocyte death: Mechanisms and translational implications. Cell Death and Disease, 2(12), e244-11.

50. Chiu, B., Viira, E., Tucker, W. and Fong, I. W. 1997. Chlamydia pneumoniae, cytomegalovirus, and herpes simplex virus in atherosclerosis of the carotid artery. Circulation, 96(7), 2144-2148.

51. Chow, C. T. L., Chow, M. S. S., Anderson, R. H. and Gosling, J. A. 2001. Autonomic Innervation of Human Cardiac Conduction System.Pdf. The Anatomical Record, 182, 169- 182.

52. Chow, L. T. C., Chow, S. S. M., Anderson, R. H. and Gosling, J. A. 1995. The innervation of the human myocardium at birth. Journal of Anatomy, 187(1), 107-114.

53. Cihakova, D. 2018. Interleukin-10 stiffens the heart. Journal of Experimental Medicine, 215(2), 379.

54. Clauss, M., Gerlach, M., Gerlach, H., Brett, J., Wang, F., Familletti, P. C., Pan, Y. C. E., Olander, J. V., Connolly, D. T. and Stern, D. 1990. Vascular permeability factor: A tumor-derived polypeptide that induces endothelial cell and monocyte procoagulant activity, and promotes monocyte migration. Journal of Experimental Medicine, 172(6), 1535-1545.

55. Clerico, A., Del Ry, S., Maffei, S., Prontera, C., Emdin, M. and Giannessi, D. 2002. The circulating levels of cardiac natriuretic hormones in healthy adults: Effects of age and sex. Clinical Chemistry and Laboratory Medicine, 40(4), 371-377.

56. Cobo, E. R. and Chadee, K. 2013. Antimicrobial human $\beta$-defensins in the colon and their role in infectious and non-infectious diseases. Pathogens, 2(1), 177-192.

57. Cody, R. J., Haas, G. J., Binkley, P. F., Capers, Q. and Kelly, R. 1993. Plasma endothelin correlates with the extent of pulmonary hypertension in patients with chronic congestive heart failure. Circulation, 87(3), 1064.

58. Cohen, K. L., van Horn, D. L., Edelhauser, H. F. and Schultz, R. O. 1979. Effect of phenylephrine on normal and regenerated endothelial cells in cat cornea. Investigative Ophthalmology and Visual Science, 18(3), 242-249.

59. Corliss, B. A., Azimi, M. S., Munson, J., Peirce, S. M. and Murfee, W. L. 2016. Macrophages: An Inflammatory Link between Angiogenesis and Lymphangiogenesis. Microcirculation, 23(2), 95-121.

60. Cosyns, B., Edwardsen, T., Hristova, K. and Hyung-Kwan, K. 2017. Left ventricle: systolic function. In The EACVI Textbook oh Echocardiography, 131-147.

61. Cracowski, J. L., Chabot, F., Labarère, J., Faure, P., Degano, B., Schwebel, C., Chaouat, A., Reynaud-Gaubert, M., Cracowski, C., Sitbon, O., Yaici, A., Simonneau, G. and Humbert, M. 2014. Proinflammatory cytokine levels are linked to death in pulmonary arterial hypertension. European Respiratory Journal, 43(3), 915-917.

62. Crick, S. J., Wharton, J., Sheppard, M. N., Royston, D., Yacoub, M. H., Anderson, R. H. and Polak, J. M. 1994. Innervation of the human cardiac conduction system: A quantitative immunohistochemical and histochemical study. Circulation, 89(4), 1697-1708.

63. Dae, M. W., O'Connell, J. W., Botvinick, E. H. and Chin, M. C. 1995. Acute and chronic effects of transient myocardial ischemia on sympathetic nerve activity, density, and norepinephrine content. Cardiovasc Res, 30(2), 270-280. 
64. Damås, J. K., Eiken, H. G., Øie, E., Bjerkeli, V., Yndestad, A., Ueland, T., Tønnessen, T., Geiran, O. R., Aass, H., Simonsen, S., Christensen, G., Frøland, S. S., Attramadal, H., Gullestad, L. and Aukrust, P. 2000. Myocardial expression of CC- and CXC-chemokines and their receptors in human end-stage heart failure. Cardiovascular Research, 47(4), 778-787.

65. Davenport, A. P., Hyndman, K. A., Dhaun, N., Southan, C., Kohan, D. E., Pollock, J. S., Pollock, D. M., Webb, D. J., Maguire, J. J. and Experimental. 2016. Endothelin. Pharmacological Reviews, 68(2), 357-418.

66. Davie, N., Haleen, S. J., Upton, P. D., Polak, J. M., Yacoub, M. H., Morrell, N. W. and Wharton, J. 2002. ETA and ETB Receptors Modulate the Proliferation of Human Pulmonary Artery Smooth Muscle Cells. American Journal of Respiratory and Critical Care Medicine, 165(3), 398-405.

67. Devaux, B., Scholz, D., Hirche, A., Klovekorn, W. P. and Schaper, J. 1997. Upregulation of cell adhesion molecules and the presence of low grade inflammation in human chronic heart failure. European Heart Journal, 18(3), 470-479.

68. Dhein, S., Giessler, C., Wangemann, T., Silber, R. E., Zerkowski, H. R. and Brodde, O. E. 2000. Differential pattern of endothelin-1-induced inotropic effects in right atria and left ventricles of the human heart. Journal of Cardiovascular Pharmacology, 36(5), 564-569.

69. Di Paolo, N. C. and Shayakhmetov, D. M. 2016. Interleukin $1 \alpha$ and the inflammatory process. Nature Immunology, 17(8), 906-913.

70. Dietrich, T., Jimenez, M., Kaye, E. A. K., Vokonas, P. S. and Garcia, R. I. 2008. Age-dependent associations between chronic periodontitis/ edentulism and risk of coronary heart disease. Circulation, 117(13), 1668-1674.

71. Dinarello, C. A., Goldin, N. P. and Wolff, S. M. 1974. Demonstration and characterization of two distinct human leukocytic pyrogens. Journal of Experimental Medicine, 139(6), 1369- 1381.

72. Dor, Y., Klewer, S. E., McDonald, J. A., Keshet, E. and Camenisch, T. D. 2003. VEGF modulates early heart valve formation. Anatomical Record - Part A Discoveries in Molecular, Cellular, and Evolutionary Biology, 271(1), 202-208.

73. Drawnel, F. M., Archer, C. R. and Roderick, H. L. 2013. The role of the paracrine/autocrine mediator endothelin-1 in regulation of cardiac contractility and growth. British Journal of Pharmacology, 168(2), 296-317.

74. Dutta, P. and Das, S. 2015. Mammalian Antimicrobial Peptides: Promising Therapeutic Targets Against Infection and Chronic Inflammation. Current Topics in Medicinal Chemistry, 16(1), 99-129.

75. Dweck, M. R., Boon, N. A. and Newby, D. E. 2012. Calcific aortic stenosis: A disease of the valve and the myocardium. Journal of the American College of Cardiology, 60(19), 1854- 1863.

76. Elmore, S. 2007. Apoptosis: A Review of Programmed Cell Death. Toxicologic Pathology, 35(4), 495-516.

77. Endlich, K. and Steinhausen, M. 1997. Natriuretic peptide receptors mediate different responses in rat renal microvessels. Kidney International, 52(1), 202-207.

78. Falanga, A., Nigro, E., de Biasi, M. G., Daniele, A., Morelli, G., Galdiero, S. and Scudiero, O. 2017. Cyclic peptides as novel therapeutic microbicides: Engineering of human defensin mimetics. Molecules, 22(7), 1-15.

79. Ferrara, N. 2004. Vascular endothelial growth factor: Basic science and clinical progress. Endocrine Reviews, 25(4), 581-611.

80. Ferrara, N., Gerber, H.-P. and LeCouter, J. 2003. The biology of VEGF and its receptors. Nature Medicine, 9, 669-676. 
81. Ferrero, E., Scabini, S., Magni, E., Foglieni, C., Belloni, D., Colombo, B., Curnis, F., Villa, A., Ferrero, M. E. and Corti, A. 2004. Chromogranin A protects vessels against tumor necrosis factor alpha-induced vascular leakage. The FASEB Journal : Official Publication of the Federation of American Societies for Experimental Biology, 18(3), 554-556.

82. Ferrero, E., Zocchi, M. R., Magni, E., Panzeri, M. C., Curnis, F., Rugarli, C., Ferrero, M. E. and Corti, A. 2001. Roles of tumor necrosis factor 555 and p75 receptors in TNF- $\alpha$-induced vascular permeability. American Journal of Physiology - Cell Physiology, 281(4 50-4), 1173- 1179.

83. Fioranelli, M., Bottaccioli, A. G., Bottaccioli, F., Bianchi, M., Rovesti, M. and Roccia, M. G. 2018. Stress and inflammation in coronary artery disease: A review psychoneuroendocrineimmunology-based. Frontiers in Immunology, 9(SEP).

84. Fischer, A. H., Jacobson, K. A., Rose, J. and Zeller, R. 2008. Hematoxylin and eosin staining of tissueand cell sections. Cold Spring Harbor Protocols, 3(5), 21356829.

85. Fliss, H. and Gattinger, D. 1996. Apoptosis in ischemic and reperfused rat myocardium. Circulation Research, 79(5), 949-956.

86. Focaccio, A., Volpe, M., Ambrosio, G., Lembo, G., Pannain, S., Rubattu, S., Enea, I., Pignalosa, S. and Chiariello, M. 1993. Angiotensin II directly stimulates release of atrial natriuretic factor in isolated rabbit hearts. Circulation, 87(1), 192-198.

87. Foo, N. C., Ahn, Y. B., Ma, X., Hyun, W. and Yen, T. S. B. 2002. Cellular vacuolization and apoptosis induced by hepatitis B virus large surface protein. Hepatology, 36(6), 1400-1407.

88. Frangogiannis, N. 2014. The immune system and the remodeling infarcted heart: cell biological insights and therapeutic opportunities. Journal of Cardiovascular Pharmacology, 63(3), $185-195$.

89. Freeman, R. V. and Otto, C. M. 2005. Spectrum of calcific aortic valve disease: Pathogenesis, disease progression, and treatment strategies. Circulation, 111(24), 3316-3326.

90. Friehs, I., Barillas, R., Vasilyev, N. V., Roy, N., McGowan, F. X. and Nido, P. J. del. 2006. Vascular Endothelial Growth Factor Prevents Apoptosis and Preserves Contractile Function in Hypertrophied Infant Heart. Circulation, 114(1), 1290-1295.

91. Frommer, K. W. and Müller-Ladner, U. 2009. Expression and function of ETA and ETB receptors in SSc. Rheumatology, 47(5), 27-28.

92. Fukuchi, M. and Giaid, A. 1998. Expression of endothelin-1 and endothelin-converting enzyme1 mRNAs and proteins in failing human hearts. Journal of Cardiovascular Pharmacology, 31(SUPPL. 1), 7-13.

93. Gaggin, H. K. and Januzzi, J. L. 2013. Biomarkers and diagnostics in heart failure. Biochimica et Biophysica Acta - Molecular Basis of Disease, 1832(12), 2442-2450.

94. Galante, A., Pietroiusti, A., Vellini, M., Piccolo, P., Possati, G., de Bonis, M., Grillo, R. L., Fontana, C. and Favalli, C. 2001. C-reactive protein is increased in patients with degenerative aortic valvular stenosis. Journal of the American College of Cardiology, 38(4), 1078-1082.

95. Galeone, A., Paparella, D., Colucci, S., Grano, M. and Brunetti, G. 2013. The role of TNF- $\alpha$ and TNF superfamily members in the pathogenesis of calcific aortic valvular disease. The Scientific World Journal, 2013, 1-10.

96. Galiuto, L., Lotrionte, M., Crea, F., Anselmi, A., Biondi-Zoccai, G. G. L., de Giorgio, F., Baldi, A., Baldi, F., Possati, G., Gaudino, M., Vetrovec, G. W. and Abbate, A. 2006. Impaired coronary and myocardial flow in severe aortic stenosis is associated with increased apoptosis: A transthoracic Doppler and myocardial contrast echocardiography study. Heart, 92(2), 208-212. 
97. Galluzzi, L., Bravo-San Pedro, J. M., Vitale, I., Aaronson, S. A., Abrams, J. M., Adam, D., Alnemri, E. S., Altucci, L., Andrews, D., Annicchiarico-Petruzzelli, M., Baehrecke, E. H., Bazan, N. G., Bertrand, M. J., Bianchi, K., Blagosklonny, M. V., Blomgren, K., Borner, C., Bredesen, D. E., Brenner, C., Kroemer, G. 2015. Essential versus accessory aspects of cell death: Recommendations of the NCCD 2015. Cell Death and Differentiation, 22(1), 58-73.

98. Garcia, J., Krause, A., Schulz, S., Rodríguez-Jiménez, F. J., Klüver, E., Adermann, K., Forssmann, U., Frimpong-Boateng, A., Bals, R. and Forssmann, W. G. 2001. Human betadefensin 4: a novel inducible peptide with a specific salt-sensitive spectrum of antimicrobial activity. The FASEB Journal, 15(10), 1819-1821.

99. García, J. R. C., Jaumann, F., Schulz, S., Krause, A., Rodríguez-Jiménez, J., Forssmann, U., Adermann, K., Klüver, E., Vogelmeier, C., Becker, D., Hedrich, R., Forssmann, W. G. and Bals, R. 2001. Identification of a novel, multifunctional $\beta$-defensin (human $\beta$-defensin 3 ) with specific antimicrobial activity: Its interaction with plasma membranes of Xenopus oocytes and the induction of macrophage chemoattraction. Cell and Tissue Research, 306(2), 257-264.

100. Garlanda, C., Dinarello, C. A. and Mantovani, A. 2013. THE INTERLEUKIN-1 FAMILY: BACK TO THE FUTURE. Immunity, 39(6), 1003-1018.

101. Généreux, P., Pibarot, P., Redfors, B., Mack, M. J., Makkar, R. R., Jaber, W. A., Svensson, L. G., Kapadia, S., Tuzcu, E. M., Thourani, V. H., Babaliaros, V., Herrmann, H. C., Szeto, W. Y., Cohen, D. J., Lindman, B. R., McAndrew, T., Alu, M. C., Douglas, P. S., Hahn, R. T., Leon, M. B. 2017. Staging classification of aortic stenosis based on the extent of cardiac damage. European Heart Journal, 38(45), 3351-3358.

102. Gerber, H. P., Dixit, V. and Ferrara, N. 1998. Vascular endothelial growth factor induces expression of the antiapoptotic proteins Bcl-2 and A1 in vascular endothelial cells. Journal of Biological Chemistry, 273(21), 13313-13316.

103. Ghosh, S. K., McCormick, T. S. and Weinberg, A. 2019. Human beta defensins and cancer: Contradictions and common ground. Frontiers in Oncology, 9(MAY), 1-8.

104. Giachini, F. R. C., Zemse, S. M., Carneiro, F. S., Lima, V. V., Carneiro, Z. N., Callera, G. E., Ergul, A., Webb, R. C. and Tostes, R. C. 2009. Interleukin-10 attenuates vascular responses to endothelin-1 via effects on ERK1/2-dependent pathway. American Journal of Physiology - Heart and Circulatory Physiology, 296(2), 1-17.

105. Giaid, A., Yanagisawa, M., Langleben, D., Michel, R. P., Levy, R., Shennib, H., Kimura, S., Masaki, T., Duguid, W. P. and Stewart, D. J. 1993. Expression of Endothelin-1 in the Lungs of Patients with Pulmonary Hypertension. The New England Journal of Medicine, 328, 1732- 1739.

106. Glumac, S., Pejić, S., Kostadinovic, S., Stojšić, Z. and Vasiljevic, J. 2016. Apoptosis in endomyocardial biopsies from patients with dilated cardiomyopathy. Folia Biologica, 62(5), 207211.

107. Goetze, J. P., Alehagen, U., Flyvbjerg, A. and Rehfeld, J. F. 2013. Making sense of chromogranin A in heart disease. The Lancet Diabetes and Endocrinology, 1(1), 7-8.

108. Grimard, B. H., Safford, R. E. and Burns, E. L. 2016. Aortic Stenosis: Diagnosis and Treatment. Am Fam Physician, 93(5), 371-378.

109. Gulati, A., Jabbour, A., Ismail, T. F., Guha, K., Khwaja, J., Raza, S., Morarji, K., Brown, T. D. H., Ismail, N. A., Dweck, M. R., di Pietro, E., Roughton, M., Wage, R., Daryani, Y., O’Hanlon, R., Sheppard, M. N., Alpendurada, F., Lyon, A. R., Cook, S. A., Prasad, S. K. 2013. Association of fibrosis with mortality and sudden cardiac death in patients with nonischemic dilated cardiomyopathy. JAMA - Journal of the American Medical Association, 309(9), 896- 908.

110. Gumauskienè, B., Krivickienè, A., Jonkaitienè, R., Vaškelytė, J. J., Siudikas, A. and Ereminienè, E. 2018. Impact of left ventricular diastolic dysfunction and biomarkers on pulmonary hypertension in patients with severe aortic stenosis. Medicina (Lithuania), 54(4), 1-9. 
111. Guo, Y., Chung, S. K., Siu, C. W., Kwan, S. C., Ho, P. W. L., Yeung, P. K. K. and Chan, K. H. 2014. Endothelin-1 overexpression exacerbate experimental allergic encephalomyelitis. Journal of Neuroimmunology, 276 (1-2), 64-70.

112. Han, R. O., Ray, P. E., Baughmann, K. L. and Feldman, A. M. 1991. Detection of interleukin and interleukin-receptor mRNA in human heart by polymerase chain reaction. Biochemical and Biophysical Research Communications, 181(2), 520-523.

113. Han, X., Kitamoto, S., Wang, H. and Boisvert, W. A. 2010. Interleukin-10 overexpression in macrophages suppresses atherosclerosis in hyperlipidemic mice. The FASEB Journal, 24(8), $2869-2880$.

114. Hanna, P. and Shivkumar, K. 2018. Targeting the Cardiac Ganglionated Plexi for Atrial Fibrillation: Modulate or Destroy? JACC: Clinical Electrophysiology, 4(10), 1359-1361.

115. Hansson, G. K. 2005. Inflammation, Atherosclerosis, and Coronary Artery Disease. $N$ Engl J Med, 352, 1685-1695.

116. Harder, J., Bartels, J., Christophers, E. and Schroder, J. M. 1997. A peptide antibiotic from human skin [6]. Nature, 387(6636), 861.

117. Harder, J., Jürgen, Bartels, J., Christophers, E. and Schröder, J. M. 2001. Isolation and Characterization of Human $\beta$-Defensin-3, a Novel Human Inducible Peptide Antibiotic. Journal of Biological Chemistry, 276(8), 5707-5713.

118. Hasan, W. 2013. Autonomic cardiac innervation: Development and adult plasticity. Organogenesis, 9(3), 129-146.

119. Haunstetter, A. and Izumo, S. 1998. Apoptosis: Basic mechanisms and implications for cardiovascular disease. Circulation Research, 82(11), 1111-1129.

120. Heatwole, V. M. 1999. TUNEL assay for apoptotic cells. Methods in Molecular Biology (Clifton, N. J.), 115, 141-148.

121. Heeschen, C., Dimmeler, S., Hamm, C. W., Fichtlscherer, S., Boersma, E., Simoons, M. L. and Zeiher, A. M. 2003. Serum level of the antiinflammatory cytokine interleukin-10 is an important prognostic determinant in patients with acute coronary syndromes. Circulation, 107(16), 2109-2114.

122. Heinisch, R. H., Zanetti, C. R., Comin, F., Fernandes, J. L., Ramires, J. A. and Serrano, C. V. 2005. Serial changes in plasma levels of cytokines in patients with coronary artery disease. Vascular Health and Risk Management, 1(3), 245-250.

123. Henein, M., Hällgren, P., Holmgren, A., Sörensen, K., Ibrahimi, P., Kofoed, K. F., Larsen, L. H. and Hassager, C. 2015. Aortic root, not valve, calcification correlates with coronary artery calcification in patients with severe aortic stenosis: A two-center study. Atherosclerosis, 243(2), 631-637.

124. Hensen, J., Abraham, W. T., Lesnefsky, E. J., Levenson, B., Groves, B. M., Schroder, K., Schrier, R. W. and Durr, J. 1992. Atrial natriuretic peptide kinetic studies in patients with cardiac dysfunction. Kidney International, 41(5), 1333-1339.

125. Hernández-Perera, O., Pérez-Sala, D., Soria, E. and Lamas, S. 2000. Involvement of Rho GTPases in the transcriptional inhibition of preproendothelin-1 gene expression by simvastatin in vascular endothelial cells. Circulation Research, 87(7), 616-622.

126. Herold, Z., Doleschall, M., Kovesdi, A., Patocs, A. and Somogyi, A. 2018. Chromogranin-A and its role in the pathogenesis of diabetes mellitus. Endokrynologia Polska, 69, 598-610.

127. Hess, O. M., Ritter, M., Schneider, J., Grimm, J., Turina, M. and Krayenbuehl, H. P. 1984. Diastolic stifness and myocardial structure in aortic. Circulation, 69(5), 855-865.

128. Heyman, S. N., Khamaisi, M. and Abassi, Z. 2018. Interacting hypoxia and endothelin in the diabetic kidney: Therapeutic options. American Journal of Physiology - Renal Physiology, 314(5), F669-F701. 
129. Higazi, A. A. R., Nassar, T., Ganz, T., Rader, D. J., Udassin, R., Bdeir, K., Hiss, E., Sachais, B. S., Williams, K. J., Leitersdorf, E. and Cines, D. B. 2000. The $\alpha$-defensins stimulate proteoglycandependent catabolism of low-density lipoprotein by vascular cells: A new class of inflammatory apolipoprotein and a possible contributor to atherogenesis. Blood, 96(4), 1393-1398.

130. Hindricks, G., Potpara, T., Dagres, N., Arbelo, E., Bax, J. J., Blomström-Lundqvist, C., Boriani, G., Castella, M., Dan, G.-A., Dilaveris, P. E., Fauchier, L., Filippatos, G., Kalman, J. M., La Meir, M., Lane, D. A., Lebeau, J.-P., Lettino, M., Lip, G. Y. H., Pinto, F. J., Watkins, C. L. 2020. 2020 ESC Guidelines for the diagnosis and management of atrial fibrillation developed in collaboration with the European Association of Cardio-Thoracic Surgery (EACTS). European Heart Journal, $1-126$.

131. Hiratsuka, T., Nakazato, M., Date, Y., Ashitani, J., Minematsu, T., Chino, N. and Matsukur, S. 1998. Identification of Human $\beta$-Defensin-2 in Respiratory Tract and Plasma and Its Increase in Bacterial Pneumonia. Biochemical and Biophysical Research Communications, 249(3), 943-947.

132. Hofman, P., van Blijswijk, B. C., Gaillard, P. J., Vrensen, G. F. J. M. and Schlingemann, R. O. 2001. Endothelial cell hypertrophy induced by vascular endothelial growth factor in the retina: New insights into the pathogenesis of capillary nonperfusion. Archives of Ophthalmology, 119(6), 861-866.

133. Hofmann, U., Beyersdorf, N., Weirather, J., Podolskaya, A., Bauersachs, J., Ertl, G., Kerkau, T. and Frantz, S. 2012. Activation of CD4 + T lymphocytes improves wound healing and survival after experimental myocardial infarction in mice. Circulation, 125(13), 1652- 1663.

134. Hogenhuis, J., Voors, A. A., Jaarsma, T., Hillege, H. L., Boomsma, F. and van Veldhuisen, D. J. 2005. Influence of age on natriuretic peptides in patients with chronic heart failure: A comparison between ANP/NT-ANP and BNP/NT-proBNP. European Journal of Heart Failure, 7(1), 81-86.

135. Hollander, M., Wolf, D. A. and Chicken, E. 2014. The Two-Sample Location Problem. In Nonparametric Statistical Methods, 115-151.

136. Hood, J. D., Meininger, C. J., Ziche, M., Granger, H. J., John, D., Meininger, C. J., Ziche, M. and Granger, H. J. 1998. VEGF upregulates ecNOS message, protein, and NO production in human endothelial cells. Am J Physiol, 274(3), 1054-1058.

137. Hosenpud, J. D., Campbell, S. M. and Mendelson, D. J. 1989. Interleukin-1-induced myocardial depression in an isolated beating heart preparation. Journal of Heart Transplantation, 8(6), 460-464.

138. Hosoda, K., Nakao, K., Hiroshi-Arai, Suga, S., Ichi, Ogawa, Y., Mukoyama, M., Shirakami, G., Saito, Y., Nakanishi, S. and Imura, H. 1991. Cloning and expression of human endothelin-1 receptor cDNA. FEBS Letters, 287(1-2), 23-26.

139. Hsu, C.-H., Reyes, L. F., Orihuela, C. J., Buitrago, R., Anzueto, A., Soni, N. J., Levine, S., Peters, J., Hinojosa, C. A., Aliberti, S., Sibila, O., Rodriguez, A., Chalmers, J. D., MartinLoeches, I., Bordon, O., Blanquer, J., Sanz, F., Marcos1, P. J., Rello, J., Restrepo, M. I. 2015. Chromogranin A levels and mortality in patients with severe sepsis. Biomarkers, 20(3), 171-176.

140. Hsu, S., Raine, L. and Fanger, H. 1981. The Use of Antiavidin Antibody and Avidin-BiotinPeroxidase Complex in Immunoperoxidase Technics. American Journal of Clinical Pathology, 75(6), 816-821.

141. Huang, W., Boyle, N. and Vaseghi, M. 2017. Cardiac innervation and the autonomic nervous system in SCD. Card Electrophysiol Clin, 9(4), 665-679.

142. Hulsmans, M., Sager, H. B., Roh, J. D., Valero-Muñoz, M., Houstis, N. E., Iwamoto, Y., Sun, Y., Wilson, R. M., Wojtkiewicz, G., Tricot, B., Osborne, M. T., Hung, J., Vinegoni, C., Naxerova, K., Sosnovik, D. E., Zile, M. R., Bradshaw, A. D., Liao, R., Tawakol, A., Nahrendorf, M. 2018. Cardiac macrophages promote diastolic dysfunction. The Journal of Experimental Medicine, 215(2), 423-440. 
143. Huttner, K. M. and Bevins, C. L. 1999. Antimicrobial Peptides as Mediators of Epithelial Host Defense. Pediatric Research, 45, 785-794.

144. Ikonomidis, I., Lekakis, J. P., Nikolaou, M., Paraskevaidis, I., Andreadou, I., Kaplanoglou, T., Katsimbri, P., Skarantavos, G., Soucacos, P. N. and Kremastinos, D. T. 2008. Inhibition of interleukin-1 by anakinra improves vascular and left ventricular function in patients with rheumatoid arthritis. Circulation, 117(20), 2662-2669.

145. Ito, H., Hiroe, M., Hirata, Y., Fujisaki, H., Adachi, S., Akimoto, H., Ohta, Y. and Marumo, F. 1994. Endothelin ETA receptor antagonist blocks cardiac hypertrophy provoked by hemodynamic overload. Circulation, 89(5), 2198-2203.

146. Jacques, D. and Bkaily, G. 2019. Endocardial endothelial cell hypertrophy takes place during the development of hereditary cardiomyopathy. Molecular and Cellular Biochemistry, 453(1-2), $157-161$.

147. Jansson, A. M., Røsjø, H., Omland, T., Karlsson, T., Hartford, M., Flyvbjerg, A. and Caidahl, K. 2009. Prognostic value of circulating chromogranin A levels in acute coronary syndromes. European Heart Journal, 30(1), 25-32.

148. Jia, H. P., Schutte, B. C., Schudy, A., Linzmeier, R., Guthmiller, J. M., Johnson, G. K., Tack, B. F., Mitros, J. P., Rosenthal, A., Ganz, T. and McCray, P. B. 2001. Discovery of new human $\beta-$ defensins using a genomics-based approach. Gene, 263(1-2), 211-218.

149. Jiang, X., Wang, F., Wang, Y., Gisterå, A., Roy, J., Paulsson-Berne, G., Hedin, U., Lerman, A., Hansson, G. K., Herrmann, J. and Yan, Z. Qun. 2019. Inflammasome-Driven Interleukin-1 $\alpha$ and Interleukin-1 $\beta$ Production in Atherosclerotic Plaques Relates to Hyperlipidemia and Plaque Complexity. JACC: Basic to Translational Science, 4(3), 304- 317.

150. Jiang, Y., Zhu, R., Luo, L., Mu, Q., Zhu, Y., Luo, H., Zou, X. and Shen, X. 2016. Recombinant Mouse $\beta$-Defensin 3 Protects against Coxsackievirus B3-Induced Myocarditis in Mice. Intervirology, 58(6), 343-349.

151. Joss, A., Akdis, M., Faith, A., Blaser, K. and Akdis, C. A. 2000. IL-10 directly acts on T cells by specifically altering the CD28 co-stimulation pathway. European Journal of Immunology, 30(6), 1683-1690.

152. Kaddoura, S. 2009. Doppler - velocities and pressures. In Echo Made Easy. Second Editon, 54-67.

153. Kallikourdis, M., Martini, E., Carullo, P., Sardi, C., Roselli, G., Greco, C. M., Vignali, D., Riva, F., Ormbostad Berre, A. M., Stølen, T. O., Fumero, A., Faggian, G., di Pasquale, E., Elia, L., Rumio, C., Catalucci, D., Papait, R. and Condorelli, G. 2017. T cell costimulation blockade blunts pressure overload-induced heart failure. Nature Communications, 8, 1-14.

154. Kamysz, W., Okrój, M. and Łukasiak, J. 2003. Novel properties of antimicrobial peptides. Acta Biochimica Polonica, 50(2), 461-469.

155. Kaneko, N., Kurata, M., Yamamoto, T., Morikawa, S. and Masumoto, J. 2019. The role of interleukin-1 in general pathology. Inflammation and Regeneration, 39(1), 1-16.

156. Kaptoge, S., di Angelantonio, E., Pennells, L., Wood, A. M., White, I. R., Gao P., Walker, M., Thompson, A., Sarwar, N., Caslake, M., Butterworth, A. S., Amouyel, P., Assmann, G., Bakker, S. J., Barr, E. L., Barrett-Connor, E., Benjamin, E. J., Björkelund, C., Brenner, H., Brunner, E., Clarke, R., Cooper, J. A., Cremer, P., Cushman, M., Dagenais, G. R. and D’Agos, D. J. 2012. CReactive Protein, Fibrinogen, and Cardiovascular Disease Prediction. New England Journal of Medicine, 367(14), 1310-1320.

157. Kelly, J., Khan, A. A., Yin, J., Ferguson, T. A. and Apte, R. S. 2007. Senescence regulates macrophage activation and angiogenic fate at sites of tissue injury in mice. Journal of Clinical Investigation, 117(11), 3421-3426.

158. Kerr, J. F. R., Wyllie, A. H. and Currie, A. R. 1972. Apoptosis: A basic biological phenomenon with wide-ranging implications in tissue kinetics. Br. J. Cancer, 26, 239. 
159. Khan, A. A., Lip, G. Y. H. and Shantsila, A. 2019. Heart rate variability in atrial fibrillation: The balance between sympathetic and parasympathetic nervous system. European Journal of Clinical Investigation, 49(11), 1-8.

160. Khot, U. N., Khot, M. B., Bajzer, C. T., Sapp, S. K., Ohman, E. M., Brener, S. J., Ellis, S. G., Lincoff, A. M. and Topol, E. J. 2003. Prevalence of Conventional Risk Factors in Patients with Coronary Heart Disease. Journal of the American Medical Association, 290(7), 898-904.

161. Kingham, P. J. and Pocock, J. M. 2000. Microglial apoptosis induced by chromogranin A is mediated by mitochondrial depolarisation and the permeability transition but not by cytochrome c release. Journal of Neurochemistry, 74(4), 1452-1462.

162. Kinzenbaw, D. A., Chu, Y., Peña Silva, R. A., Didion, S. P. and Faraci, F. M. 2013. Interleukin10 protects against aging-induced endothelial dysfunction. Physiological Reports, 1(6), 1-8.

163. Kivelä, R., Hemanthakumar, K. A., Vaparanta, K., Robciuc, M., Izumiya, Y., Kidoya, H., Takakura, N., Peng, X., Sawyer, D. B., Elenius, K., Walsh, K. and Alitalo, K. 2019. Endothelial Cells Regulate Physiological Cardiomyocyte Growth via VEGFR2-Mediated Paracrine Signaling. Circulation, 139(22), 2570-2584.

164. Kjær, A. and Hesse, B. 2001. Heart failure and neuroendocrine activation: Diagnostic, prognostic and therapeutic perspectives. Clinical Physiology, 21(6), 661-672.

165. Knuuti, J., Wijns, W., Chairperson, I., Capodanno, D., France, C. F., Denmark, E. P., Storey, R. F., Kingdom, U., Deaton, C., Kingdom, U., France, T. C., Gersh, B. J., States, U., Svitil, P., Republic, C., France, M. G., Israel, D. H., Hatala, R., Republic, S., Bax, J. J. 2019. 2019. ESC Guidelines for the diagnosis and management of chronic coronary syndromes The Task Force for the diagnosis and management of chronic. European Heart Journal, 1-71.

166. Koenig, W., Sund, M., Fröhlich, M., Fischer, H., Döring, A., Hutchinson, W. L. and Pepys, M. B. 1999. C-Reactive Protein, a Sensitive Marker of Inflammation, Predicts Future Risk of Coronary Heart Disease in Initially Healthy Middle-Aged Men. Circulation, 99, 237-243.

167. Kohan, D. E., Inscho, E. W., Wesson, D. and Pollock, D. M. 2011. Physiology of endothelin and the kidney. Comprehensive Physiology, 1(2), 883-919.

168. Kougias, P., Chai, H., Lin, P. H., Yao, Q., Lumsden, A. B. and Chen, C. 2005. Defensins and cathelicidins: Neutrophil peptides with roles in inflammation, hyperlipidemia and atherosclerosis. Journal of Cellular and Molecular Medicine, 9(1), 3-10.

169. Kuhn, M. 2012. Endothelial actions of atrial and B-type natriuretic peptides. British Journal of Pharmacology, 166(2), 522-531.

170. Kuo, C., Shor, A., Campbell, L. A., Fukushi, H., Patton, D. L. and Grayston, J. T. 1993. Demonstration of Chlamydia pneumoniae in Atherosclerotic Lesions of Coronary Arteries. The Journal of Infectious Diseases, 167(4), 841-849.

171. Laakkonen, J. P., Lähteenvuo, J., Jauhiainen, S., Heikura, T. and Ylä-Herttuala, S. 2019. Beyond endothelial cells: Vascular endothelial growth factors in heart, vascular anomalies and placenta. Vascular Pharmacology, 112(October 2018), 91-101.

172. Lancellotti, P., Magne, J., Donal, E., O’Connor, K., Dulgheru, R., Rosca, M. and Pierard, L. A. 2012. Determinants and prognostic significance of exercise pulmonary hypertension in asymptomatic severe aortic stenosis. Circulation, 126(7), 851-859.

173. Lang, R. M., Badano, L. P., Victor, M. A., Afilalo, J., Armstrong, A., Ernande, L., Flachskampf, F. A., Foster, E., Goldstein, S. A., Kuznetsova, T., Lancellotti, P., Muraru, D., Picard, M. H., Retzschel, E. R., Rudski, L., Spencer, K. T., Tsang, W. and Voigt, J. U. 2015. Recommendations for cardiac chamber quantification by echocardiography in adults: An update from the American Society of Echocardiography and the European Association of Cardiovascular Imaging. Journal of the American Society of Echocardiography, 28(1), 1-39.

174. Lankhorst, S., Danser, A. H. J. and van den Meiracker, A. H. 2016. Endothelin-1 and antiangiogenesis. Am J Physiol Regul Integr Comp Physiol, 310, 230-234. 
175. Laroumanie, F., Douin-Echinard, V., Pozzo, J., Lairez, O., Tortosa, F., Vinel, C., Delage, C., Calise, D., Dutaur, M., Parini, A. and Pizzinat, N. 2014. CD4+ T cells promote the transition from hypertrophy to heart failure during chronic pressure overload. Circulation, 129(21), 2111-2124.

176. Leonard, B. C., Affolter, V. K. and Bevins, C. L. 2012. Antimicrobial peptides: Agents of border protection for companion animals. Veterinary Dermatology, 23(3).

177. Leopold, J. 2013. Cellular Mechanisms of Aortic Valve Calcification. Circ Cardiovasc Interv, 5(4), 605-614.

178. Libby, P. 2013. Collagenases and cracks in the plaque. Journal of Clinical Investigation, 123(8), 3201-3203.

179. Libby, P., Ridker, P. M. and Hansson, G. K. 2009. Inflammation in AtherosclerosisFrom Pathophysiology to Practice. Journal of the American College of Cardiology, 54(23), 2129- 2138.

180. Linde, A., Mosier, D., Blecha, F. and Melgarejo, T. 2007. Innate immunity and inflammation New frontiers in comparative cardiovascular pathology. Cardiovascular Research, 73(1), 26-36.

181. Linde, A., Ross, C., Blecha, F., Lushington, G. H. and Melgarejo, T. 2013. Cardiac beta-defensins upregulate with a high fat diet and influence monocyte migration. Open Journal of Internal Medicine, 03(02), 81-94.

182. Lindman, B. R., Clavel, M.-A., Mathieu, P., Iung, B., Lancellotti, P., Otto, C. M. and Pibarot, P. 2016. Calcific aortic stenosis. Nature Reviews. Disease Primers, 2, 16006.

183. Ling, L., Maguire, J. J. and Davenport, A. P. 2013. Endothelin-2, the forgotten isoform: Emerging role in the cardiovascular system, ovarian development, immunology and cancer. British Journal of Pharmacology, 168(2), 283-295.

184. Liu, A. Y., Destoumieux, D., Wong, A. V., Park, C. H., Valore, E. V., Liu, L. and Ganz, T. 2002. Human $\beta$-defensin-2 production in keratinocytes is regulated by interleukin-1, bacteria, and the state of differentiation. Journal of Investigative Dermatology, 118(2), 275-281.

185. Liu, X., Sun, L., Chen, J., Jin, Y., Liu, Q., Xia, Z., Wang, L. and Li, J. 2017. Effects of local cardiac denervation on cardiac innervation and ventricular arrhythmia after chronic myocardial infarction. PLOS ONE, 12(7), 1-11.

186. Liuzzo, G., Biasucci, L., Gallimore, J., Grillo, R., Rebuzzi, A., Pepys, M. and Maseri, A. 1994. The prognostic value of $\mathrm{C}$-reactive protein and serum amyloid a protein in severe unstable angina. N Engl J Med, 331(7), 417-424.

187. Loh, Y. P., Cheng, Y., Mahata, S. K., Corti, A. and Tota, B. 2012. Chromogranin A and derived peptides in health and disease. Journal of Molecular Neuroscience, 48(2), 347-356.

188. López-Bermejo, A., Chico-Julià, B., Castro, A., Recasens, M., Esteve, E., Biarnés, J., Casamitjana, R., Ricart, W. and Fernández-Real, J. M. 2007. Alpha defensins 1, 2, and 3: Potential roles in dyslipidemia and vascular dysfunction in humans. Arteriosclerosis, Thrombosis, and Vascular Biology, 27(5), 1166-1171.

189. Lucero, D., Islam, P., Freeman, L. A., Jin, X., Pryor, M., Tang, J., Kruth, H. S. and Remaley, A. T. 2020. Interleukin 10 promotes macrophage uptake of HDL and LDL by stimulating fluid-phase endocytosis. Biochimica et Biophysica Acta - Molecular and Cell Biology of Lipids, 1865(2), 158537.

190. Luçon, A., Oger, E., Bedossa, M., Boulmier, D., Verhoye, J. P., Eltchaninoff, H., Iung, B., Leguerrier, A., Laskar, M., Leprince, P., Gilard, M. and le Breton, H. 2014. Prognostic implications of pulmonary hypertension in patients with severe aortic stenosis undergoing transcatheter aortic valve implantation study from the france 2 registry. Circulation: Cardiovascular Interventions, 7(2), 240-247. 
191. Lugrin, J., Parapanov, R., Rosenblatt-Velin, N., Rignault-Clerc, S., Feihl, F., Waeber, B., Müller, O., Vergely, C., Zeller, M., Tardivel, A., Schneider, P., Pacher, P. and Liaudet, L. 2015. Interleukin-1 alpha is a crucial danger signal triggering acute myocardial inflammation during myocardial infarction. The Journal of Immunology, 194(2), 499-503.

192. Lukens, J. R., Gross, J. M. and Kanneganti, T. D. 2012. IL-1 family cytokines trigger sterile inflammatory disease. Frontiers in Immunology, 3, 1-12.

193. Mabeta, P. 2013. Decreased secretion of vascular endothelial growth factor is associated with increased apoptosis in vascular tumor derived endothelial cells. Journal of Physiology and Pharmacology, 64(4), 473-477.

194. Mach, F., Baigent, C., Catapano, A. L., Koskinas, K. C., Casula, M., Badimon, L., Chapman, M. J., de Backer, G. G., Delgado, V., Ference, B. A., Graham, I. M., Halliday, A., Landmesser, U., Mihaylova, B., Pedersen, T. R., Riccardi, G., Richter, D. J., Sabatine, M. S., Taskinen, M. R., Patel, R. S. 2020. 2019 ESC/EAS Guidelines for the management of dyslipidaemias: Lipid modification to reduce cardiovascular risk. European Heart Journal, 41(1), 111-188.

195. Madanecki, P., Kapoor, N., Bebok, Z., Ochocka, R., Collawn, J. F. and Bartoszewski, R. 2013. Regulation of angiogenesis by hypoxia: The role of microRNA. Cellular and Molecular Biology Letters, 18(1), 47-57.

196. Maeder, M. T., Weber, L., Buser, M., Gerhard, M., Haager, P. K., Maisano, F. and Rickli, H. 2018. Pulmonary Hypertension in Aortic and Mitral Valve Disease. Frontiers in Cardiovascular Medicine, 5, 1-15.

197. Maguire, J. J. and Davenport, A. P. 2015. Endothelin Receptors and Their Antagonists. Seminars in Nephrology, 35(2), 125-136.

198. Mahata, S. K., Mahata, M., Wakade, A. R. and O’Connor, D. T. 2000. Primary structure and function of the catecholamine release inhibitory peptide catestatin (chromogranin A344-364): Identification of amino acid residues crucial for activity. Molecular Endocrinology, 14(10), $1525-1535$.

199. Mahata, Sushil, K. and Corti, A. 2019. Chromogranin a and its fragments in cardiovascular, immunometabolic, and cancer regulation. Annals of the New York Academy of Sciences, 1455(1), $34-58$.

200. Maki, T., Horio, T., Yoshihara, F., Suga, S. I., Takeo, S., Matsuo, H. and Kangawa, K. 2000. Effect of neutral endopeptidase inhibitor on endogenous atrial natriuretic peptide as a paracrine factor in cultured cardiac fibroblasts. British Journal of Pharmacology, 131(6), 1204-1210.

201. Mangoni, M., McDermott, A. and Zasloff, M. 2016. Antimicrobial peptides and wound healing: biological and therapeutic considerations. Exp Dermatol, 25(3), 167-173.

202. Mann, D. L. 2002. Inflammatory mediators and the failing heart: Past, present, and the foreseeable future. Circulation Research, 91(11), 988-998.

203. Marotta, V., Zatelli, M. C., Sciammarella, C., Ambrosio, M. R., Bondanelli, M., Colao, A. and Faggiano, A. 2018. Chromogranin a as circulating marker for diagnosis and management of neuroendocrine neoplasms: More flaws than fame. Endocrine-Related Cancer, 25(1), 11-29.

204. Marron, K., Wharton, J., Sheppard, M. N., Fagan, D., Royston, D., Kuhn, D. M., de Leval, M. R., Whitehead, B. F., Anderson, R. H. and Polak, J. M. 1995. Distribution, morphology, and neurochemistry of endocardial and epicardial nerve terminal arborizations in the human heart. Circulation, 92(8), 2343-2351.

205. Martini, E., Kunderfranco, P., Peano, C., Carullo, P., Cremonesi, M., Schorn, T., Carriero, R., Termanini, A., Colombo, F. S., Jachetti, E., Panico, C., Faggian, G., Fumero, A., Torracca, L., Molgora, M., Cibella, J., Pagiatakis, C., Brummelman, J., Alvisi, G., Kallikourdis, M. 2019. Single-Cell Sequencing of Mouse Heart Immune Infiltrate in Pressure Overload-Driven Heart Failure Reveals Extent of Immune Activation. Circulation, 140(25), 2089-2107. 
206. Mathieu, P. and Boulanger, M. C. 2014. Basic mechanisms of calcific aortic valve disease. Canadian Journal of Cardiology, 30(9), 982-993.

207. Matsuura, A., Yamochi, W., Hirata, K. I., Kawashima, S. and Yokoyama, M. 1998. Stimulatory interaction between vascular endothelial growth factor and endothelin-1 on each gene expression. Hypertension, 32(1), 89-95.

208. Mauro, A. G., Mezzaroma, E., Torrado, J., Kundur, P., Joshi, P., Stroud, K., Quaini, F., Lagrasta, C. A., Abbate, A. and Toldo, S. 2017. Reduction of Myocardial Ischemia-Reperfusion Injury by Inhibiting Interleukin-1 Alpha. Journal of Cardiovascular Pharmacology, 69(3), 156-160.

209. McKechnie, R. S. and Rubenfire, M. 2002. The role of inflammation and infection in coronary artery Disease: A clinical perspective. ACC Current Journal Review, 11(1), 32-34.

210. Meador, B. M., Krzyszton, C. P., Johnson, R. W. and Huey, K. A. 2008. Effects of IL-10 and age on IL-6, IL-1 $\beta$, and TNF- $\alpha$ responses in mouse skeletal and cardiac muscle to an acute inflammatory insult. Journal of Applied Physiology, 104(4), 991-997.

211. Meier, P., Gloekler, S., Zbinden, R., Beckh, S., de Marchi, S. F., Zbinden, S., Wustmann, K., Billinger, M., Vogel, R., Cook, S., Wenaweser, P., Togni, M., Windecker, S., Meier, B. and Seiler, C. 2007. Beneficial Effect of Recruitable Collaterals. Circulation, 116(9), 975-983.

212. Melincovici, C. S., Boşca, A. B., Şuşman, S., Mărginean, M., Mihu, C., Istrate, M., Moldovan, I. M., Roman, A. L. and Mihu, C. M. 2018. Vascular endothelial growth factor (VEGF) - key factor in normal and pathological angiogenesis. Romanian Journal of Morphology and Embryology, 59(2), 455-467.

213. Meyer, M., Lehnart, S., Pieske, B., Schlottauer, K., Munk, S., Holubarsch, C., Just, H. and Hasenfuss, G. 1996. Influence of endothelin 1 on human atrial myocardium - Myocardial function and subcellular pathways. Basic Research in Cardiology, 91(1), 86-93.

214. Michel, J. B., Martin-Ventura, J. L., Nicoletti, A. and Ho-Tin-Noé, B. 2014. Pathology of human plaque vulnerability: Mechanisms and consequences of intraplaque haemorrhages. Atherosclerosis, 234(2), 311-319.

215. Milin, A. C., Vorobiof, G., Aksoy, O. and Ardehali, R. 2014. Insights Into Aortic Sclerosis and Its Relationship With Coronary Artery Disease. Journal of the American Heart Association, 3(5), $1-12$.

216. Mitchell, G. A. 1953. The innervation of the heart. British Heart Journal, 15(2), 159-171.

217. Miyauchi, T. and Sakai, S. 2019. Endothelin and the heart in health and diseases. Peptides, 111(June 2018), 77-88.

218. Moraitis, A. G., Freeman, L. A., Shamburek, R. D., Wesley, R., Wilson, W., Grant, C. M., Price, S., Demosky, S., Thacker, S. G., Zarzour, A., Hornung, R. L., Pucino, F., Csako, G., Yarboro, C., McInnes, I. B., Kuroiwa, T., Boumpas, D., Rao, V. K., Illei, G. G. and Remaley, A. T. 2015. Elevated Interleukin-10: A New Cause of Dyslipidemia Leading to Severe HDL Deficiency. $J$ Clin Lipidol, 9(1), 81-90.

219. Moreno, P. R., Astudillo, L., Elmariah, S., Purushothaman, K. R., Purushothaman, M., Lento, P. A., Sharma, S. K., Fuster, V. and Adams, D. H. 2011. Increased macrophage infiltration and neovascularization in congenital bicuspid aortic valve stenosis. Journal of Thoracic and Cardiovascular Surgery, 142(4), 895-901.

220. Morita, E., Yasue, H., Yoshimura, M., Ogawa, H., Jougasaki, M., Matsumura, T., Mukoyama, M. and Nakao, K. 1993. Increased plasma levels of brain natriuretic peptide in patients with acute myocardial infarction. Circulation, 88(1), 82-91.

221. Morton, A. C., Rothman, A. M. K., Greenwood, J. P., Gunn, J., Chase, A., Clarke, B., Hall, A. S., Fox, K., Foley, C., Banya, W., Wang, D., Flather, M. D. and Crossman, D. C. 2015. The effect of interleukin-1 receptor antagonist therapy on markers of inflammation in non-ST elevation acute coronary syndromes: The MRC-ILA Heart Study. European Heart Journal, 36(6), 377-384. 
222. Mosser, D. M. and Zhang, X. 2008. Interleukin-10: new perspectives on an old cytokine. Immunol Rev, 226, 205-218.

223. Mraiche, F., Cena, J., Das, D. and Vollrath, B. 2005. Effects of statins on vascular function of endothelin-1. British Journal of Pharmacology, 144(5), 715-726.

224. Muntjewerff, E. M., Dunkel, G., Nicolasen, M. J. T., Mahata, S. K. and van den Bogaart, G. 2018. Catestatin as a target for treatment of inflammatory diseases. Frontiers in Immunology, 9, 1-10.

225. Nadlonek, N., Lee, J. H., Reece, T. B., Weyant, M. J., Cleveland, J. C., Meng, X. and Fullerton, D. A. 2013. Interleukin-1 beta induces an inflammatory phenotype in human aortic valve interstitial cells through nuclear factor kappa beta. Annals of Thoracic Surgery, 96(1), 155- 162.

226. Nakagawa, Y., Nishikimi, T. and Kuwahara, K. 2019. Atrial and brain natriuretic peptides: Hormones secreted from the heart. Peptides, 111(February 2018), 18-25.

227. Namiki, A., Brogi, E., Kearney, M., Kim, E. A., Wu, T., Couffinhal, T., Varticovski, L. and Isner, J. M. 1995. Hypoxia induces vascular endothelial growth factor in cultured human endothelial cells. Journal of Biological Chemistry, 270(52), 31189-31195.

228. Negoescu, A., Lorimier, P., Labat-Moleur, F., Drouet, C., Robert, C., Guillermet, C., Brambilla, C. and Brambilla, E. 1996. In situ apoptotic cell labeling by the TUNEL method: Improvement and evaluation on cell preparations. Journal of Histochemistry and Cytochemistry, 44(9), 959-968.

229. Neufeld, G., Cohen, T., Gengrinovitch, S. and Zoya, P. 1999. Vascular endothelial growth factor (VEGF) and its receptors. The FASEB Journal, 13(1), 9-22.

230. Nguyen, B. L., Fishbein, M. C., Chen, L. S., Chen, P. S. and Masroor, S. 2009. Histopathological substrate for chronic atrial fibrillation in humans. Heart Rhythm, 6(4), 454- 460.

231. Nishihira, K., Imamura, T., Yamashita, A., Hatakeyama, K., Shibata, Y., Nagatomo, Y., Date, H., Kita, T., Eto, T. and Asada, Y. 2006. Increased expression of interleukin-10 in unstable plaque obtained by directional coronary atherectomy. European Heart Journal, 27(14), 1685-1689.

232. Nishikimi, T., Maeda, N. and Matsuoka, H. 2006. The role of natriuretic peptides in cardioprotection. Cardiovascular Research, 69(2), 318-328.

233. Noireaud, J. and Andriantsitohaina, R. 2014. Recent insights in the paracrine modulation of cardiomyocyte contractility by cardiac endothelial cells. In BioMed Research International 10.

234. Novaro, G. M., Katz, R., Aviles, R. J., Gottdiener, J. S., Cushman, M., Psaty, B. M., Otto, C. M. and Griffin, B. P. 2007. Clinical Factors, But Not C-Reactive Protein, Predict Progression of Calcific Aortic-Valve Disease. The Cardiovascular Health Study. Journal of the American College of Cardiology, 50(20), 1992-1998.

235. O’Brien, K. D. 2006. Pathogenesis of calcific aortic valve disease: A disease process comes of age (and a good deal more). Arteriosclerosis, Thrombosis, and Vascular Biology, 26(8), $1721-1728$.

236. O’Connor, D. 1985. Plasma chromogranin A. Initial Studies in Human Hypertension. Hypertension, 7(3), 76-79.

237. O’Neil, D. A., Porter, E. M., Elewaut, D., Anderson, G. M., Eckmann, L., Ganz, T. and Kagnoff, M. F. 1999. Expression and regulation of the human beta-defensins hBD-1 and hBD-2 in intestinal epithelium. Journal of Immunology, 163(12), 6718-6724.

238. Olivetti, G., Abbi, R., Quaini, F., Kajstura, J., Cheng, W., Nitahara, J. A., Quaini, E., di Loreto, C., Beltrami, C. A., Krajewski, S., Reed, J. C. and Anversa, P. 1997. Apoptosis in the failing human heart. New England Journal of Medicine, 336(16), 1131-1141.

239. Omland, T., Lie, R. T., Aakvaag, A., Aarsland, T. and Dickstein, K. 1994. Plasma endothelin determination as a prognostic indicator of 1-year mortality after acute myocardial infarction. Circulation, 89(4), 1573-1579. 
240. Osnabrugge, R. L. J., Mylotte, D., Head, S. J., van Mieghem, N. M., Nkomo, V. T., Lereun, C. M., Bogers, A. J. J. C., Piazza, N. and Kappetein, A. P. 2013. Aortic stenosis in the elderly: Disease prevalence and number of candidates for transcatheter aortic valve replacement: A metaanalysis and modeling study. Journal of the American College of Cardiology, 62(11), 1002-1012.

241. Owens, D., Katz, R., Takasu, J., Kronmal, R., Budoff, M. and O`Brien, K. 2010. Incidence and Progression of Aortic Valve Calcium in the MultiEthnic Study of Atherosclerosis (MESA). Am J Cardiol, 105(5), 701-708.

242. Patel, B., Bansal, S. S., Ismahil, M. A., Hamid, T., Rokosh, G., Mack, M. and Prabhu, S. D. 2018. CCR2+ Monocyte-Derived Infiltrating Macrophages Are Required for Adverse Cardiac Remodeling During Pressure Overload. JACC: Basic to Translational Science, 3(2), 230-244.

243. Pawade, T. A., Newby, D. E. and Dweck, M. R. 2015. Calcification in aortic stenosis: The skeleton key. Journal of the American College of Cardiology, 66(5), 561-577.

244. Pazgier, M., Hoover, D. M., Yang, D., Lu, W. and Lubkowski, J. 2006. Human $\beta$-defensins. Cellular and Molecular Life Sciences, 63(11), 1294-1313.

245. Penna, C., Pasqua, T., Amelio, D., Perrelli, M. G., Angotti, C., Tullio, F., Mahata, S. K., Tota, B., Pagliaro, P., Cerra, M. C. and Angelone, T. 2014. Catestatin increases the expression of antiapoptotic and pro-angiogenetic factors in the post-ischemic hypertrophied heart of SHR. PLoS ONE, 9(8), 1-11.

246. Pepys, M. B. and Hirschfield, G. M. 2003. C-reactive protein: a critical update. Journal of Clinical Investigation, 112(2), 299-299.

247. Perez, A. L., Grodin, J. L., Wu, Y., Hernandez, A. F., Butler, J., Metra, M., Felker, G. M., Voors, A. A., McMurray, J. J., Armstrong, P. W., Starling, R. C., O’Connor, C. M. and Tang, W. H. W. 2016. Increased mortality with elevated plasma endothelin-1 in acute heart failure: An ASCENDHF biomarker substudy. European Journal of Heart Failure, 18(3), 290-297.

248. Persic, V., Bastiancic, A. L., Rosovic, I., Raljevic, D., Samsa, D. T., Bastiancic, L., Miskulin, R., Boban, M. and Laskarin, G. 2018. Correlation between immunological-inflammatory markers and endothelial disfunction in the early stage of coronary heart disease. Medical Hypotheses, 115(April), 72-76.

249. Perticone, M., Zito, R., Miceli, S., Pinto, A., Suraci, E., Greco, M., Gigliotti, S., Hribal, M. L., Corrao, S., Sesti, G. and Perticone, F. 2019. Immunity, Inflammation and Heart Failure: Their Role on Cardiac Function and Iron Status. Frontiers in Immunology, 10(October), 1-9.

250. Piepoli, M. F., Hoes, A. W., Agewall, S., Albus, C., Brotons, C., Catapano, A. L., Cooney, M. T., Corrà, U., Cosyns, B., Deaton, C., Graham, I., Hall, M. S., Hobbs, F. D. R., Løchen, M. L., Löllgen, H., Marques-Vidal, P., Perk, J., Prescott, E., Redon, J., Gale, C. 2016. 2016 European Guidelines on cardiovascular disease prevention in clinical practice. European Heart Journal, 37(29), 2315-2381.

251. Pieroni, M., Corti, A., Tota, B., Curnis, F., Angelone, T., Colombo, B., Cerra, M. C., Bellocci, F., Crea, F. and Maseri, A. 2007. Myocardial production of chromogranin A in human heart: A new regulatory peptide of cardiac function. European Heart Journal, 28(9), 1117-1127.

252. Pierri, H., Higuchi-Dos-Santos, M. H., Higuchi, M. D. L., Palomino, S., Sambiase, N. V., Demarchi, L. M. M., Rodrigues, G. H. D. P., Nussbacher, A., Ramires, J. A. F. and Wajngarten, M. 2006. Density of Chlamydia pneumoniae is increased in fibrotic and calcified areas of degenerative aortic stenosis. International Journal of Cardiology, 108(1), 43-47.

253. Pilkington, S. M., Dearman, R. J., Kimber, I. and Griffiths, C. E. M. 2018. Langerhans cells express human $\beta$-defensin 3: relevance for immunity during skin ageing. British Journal of Dermatology, 179(5), 1170-1171.

254. Pilmane M., Rumba I., Sundler F. L. A. 1998. Patterns of distribution and occurrence of neuroendocrine elements in lungs of humans with chronic lung diseases. The Journal of Latvian Academy of Sciences, 52, 144-152. 
255. Piro, F. R., di Gioia, C. R., Gallo, P., Giordano, C. and D’Amati, G. 2000. Is apoptosis a diagnostic marker of acute myocardial infarction? Archives of Pathology and Laboratory Medicine, 124(6), 827-831.

256. Ponikowski, P., Voors, A. A., Anker, S. D., Bueno, H., Cleland, J. G. F., Coats, A. J. S., Falk, V., González-Juanatey, J. R., Harjola, V. P., Jankowska, E. A., Jessup, M., Linde, C., Nihoyannopoulos, P., Parissis, J. T., Pieske, B., Riley, J. P., Rosano, G. M. C., Ruilope, L. M., Ruschitzka, F., Davies, C. 2016. 2016 ESC Guidelines for the diagnosis and treatment of acute and chronic heart failure. European Heart Journal, 37(27), 2129-2200.

257. Potz, B. A., Parulkar, A. B., Abid, R. M., Sodha, N. R. and Sellke, F. W. (2017). Novel molecular targets for coronary angiogenesis and ischemic heart disease. Coronary Artery Disease, 28(7), 605-613.

258. Pousset, F., Isnard, R., Lechat, P., Kalotka, H., Carayon, A., Maistre, G., Escolano, S., Thomas, D. and Komajda, M. 1997. Prognostic value of plasma endothelin-1 in patients with chronic heart failure. European Heart Journal, 18(2), 254-258.

259. Prahl, A., Pazgier, M., Alexandratos, J. and Lubkowski, J. 2016. Human $\beta$-defensin 4 - defensin without the "twist". Postepy Biochemii, 62(3), 349-361.

260. Pudil, R., Vasatova, M., Fucikova, A., Rehulkova, H., Rehulka, P., Palicka, V. and Stulik, J. 2015. Vascular endothelial growth factor is associated with the morphologic and functional parameters in patients with hypertrophic cardiomyopathy. BioMed Research International, 2015, 1-7.

261. Rabinovitch, M., Guignabert, C., Humbert, M. and Nicolls, M. R. 2014. Inflammation and Immunity in the Pathogenesis of Pulmonary Arterial Hypertension. Circ Res, 115(1), 165- 175.

262. Rajendran, P., Rengarajan, T., Thangavel, J., Nishigaki, Y., Sakthisekaran, D., Sethi, G. and Nishigaki, I. 2013. The vascular endothelium and human diseases. International Journal of Biological Sciences, 9(10), 1057-1069.

263. Ramakrishnan, S., Anand, V. and Roy, S. 2014. Vascular endothelial growth factor signaling in hypoxia and inflammation. Journal of Neuroimmune Pharmacology, 9(2), 142-160.

264. Ramos, M. A., Kuzuya, M., Esaki, T., Miura, S., Satake, S., Asai, T., Kanda, S., Hayashi, T. and Iguchi, A. 1998. Induction of macrophage VEGF in response to oxidized LDL and VEGF accumulation in human atherosclerotic lesions. Arteriosclerosis, Thrombosis, and Vascular Biology, 18(7), 1188-1196.

265. Rider, P., Carmi, Y., Guttman, O., Braiman, A., Cohen, I., Voronov, E., White, M. R., Dinarello, C. A. and Apte, R. N. 2011. IL-1 $\alpha$ and IL-1 $\beta$ Recruit Different Myeloid Cells and Promote Different Stages of Sterile Inflammation. The Journal of Immunology, 187(9), 4835- 4843.

266. Rocca, C., Scavello, F., Colombo, B., Gasparri, A. M., Dallatomasina, A., Granieri, M. C., Amelio, D., Pasqua, T., Cerra, M. C., Tota, B., Corti, A. and Angelone, T. 2019. Physiological levels of chromogranin A prevent doxorubicin-induced cardiotoxicity without impairing its anticancer activity. FASEB Journal, 33(6), 7734-7747.

267. Rocha, N. P., Colpo, G. D., Bravo-Alegria, J., Lincoln, J. A., Wolinsky, J. S., Lindsey, J. W., Teixeira, A. L. and Freeman, L. 2019. Exploring the relationship between Endothelin-1 and peripheral inflammation in multiple sclerosis. Journal of Neuroimmunology, 326(August 2018), 45-48.

268. Roivainen, M., Viik-Kajander, M., Palosuo, T., Toivanen, P., Leinonen, M., Saikku, P., Tenkanen, L., Manninen, V., Hovi, T. and Maanttaari, M. 2000. Infections, Inflammation, and the Risk of Coronary Heart Disease. Circulation, 101, 252-257.

269. Rossebø, A. B., Pedersen, T. R., Boman, K., Brudi, P., Chambers, J. B., Egstrup, K., Gerdts, E., Gohlke-Bärwolf, C., Holme, I., Kesäniemi, Y. A., Malbecq, W. and Nienaber, C. A. 2008. Intensive Lipid Lowering with Simvastatin and Ezetimibe in Aortic Stenosis. New England Journal of Medicine, 359, 1343-1356. 
270. Rudski, L. G., Lai, W. W., Afilalo, J., Hua, L., Handschumacher, M. D., Chandrasekaran, K., Solomon, S. D., Louie, E. K. and Schiller, N. B. 2010. Guidelines for the Echocardiographic Assessment of the Right Heart in Adults: A Report from the American Society of Echocardiography. Journal of the American Society of Echocardiography, 23(7), 685-713.

271. Rūmanss, G. M., Kažoka, D. and Pilmane, M. 2019a. Sirds asinsvadi. In Klīniskā anatomija medicinas studentiem, 132-135.

272. Rūmanss, G. M., Kažoka, D. and Pilmane, M. 2019b. Sirds dobumi. In Klīniskā anatomija medicinas studentiem, 127-131.

273. Rūmanss, G. M., Kažoka, D. and Pilmane, M. 2019c. Sirds inervācija. In Klīniskā anatomija medicinas studentiem, 135-136.

274. Sabbagh, A. El and Nishimura, R. A. 2017. Clinical conundrum of coronary artery disease and aortic valve stenosis. Journal of the American Heart Association, 6(2), 1-3.

275. Saito, Y. 2010. Roles of atrial natriuretic peptide and its therapeutic use. Journal of Cardiology, 56(3), 262-270.

276. Saraiva, M., Vieira, P. and O'Garra, A. 2020. Biology and therapeutic potential of interleukin-10. Journal of Experimental Medicine, 217(1), 1-19.

277. Saraste, A., Pulkki, K., Kallajoki, M., Henriksen, K., Parvinen, M. and Voipio-Pulkki, L. M. 1997. Apoptosis in human acute myocardial infarction. Circulation, 95(2), 320-323.

278. Sattar, Y., Rauf, H., Bareeqa, S. B., Ullah, W. and Myla, M. 2019. Transcatheter Aortic Valve Replacement versus Surgical Aortic Valve Replacement: A Review of Aortic Stenosis Management. Cureus, 11(12), 1-9.

279. Saxena, A., Khosraviani, S., Noel, S., Mohan, D., Donner, T. and Hamad, A. R. A. 2015. Interleukin-10 paradox: A potent immunoregulatory cytokine that has been difficult to harness for immunotherapy. Cytokine, 74(1), 27-34.

280. Schirone, L., Forte, M., Palmerio, S., Yee, D., Nocella, C., Angelini, F., Pagano, F., Schiavon, S., Bordin, A., Carrizzo, A., Vecchione, C., Valenti, V., Chimenti, I., Falco, E. de, Sciarretta, S. and Frati, G. 2017. A Review of the Molecular Mechanisms Underlying the Development and Progression of Cardiac Remodeling. Oxidative Medicine and Cellular Longevity, 1-16.

281. Schneider, M. P., Boesen, E. I. and Pollock, D. M. 2007. Contrasting Actions of Endothelin ETA and ETB Receptors in Cardiovascular Disease. Annu Rev Pharmacol Toxicol, 47, 731-759.

282. Schumacher, S. M. and Prasad, S. V. N. 2018. Tumor Necrosis Factor- $\alpha$ in Heart Failure: an Updated Review. Current Cardiology Reports, 20(11), 1-20.

283. Scridon, A., Şerban, R. C. and Chevalier, P. 2018. Atrial fibrillation: Neurogenic or myogenic? Archives of Cardiovascular Diseases, 111(1), 59-69.

284. Semlali, A., Al Amri, A., Azzi, A., Al Shahrani, O., Arafah, M., Kohailan, M., Aljebreen, A. M., Alharbi, O., Almadi, M. A., Azzam, N. A., Parine, N. R., Rouabhia, M. and Alanazi, M. S. 2015. Expression and new exon mutations of the human beta defensins and their association on colon cancer development. PLOS ONE, 10(6), 1-16.

285. Sengenès, C., Bouloumié, A., Hauner, H., Berlan, M., Busse, R., Lafontan, M. and Galitzky, J. 2003. Involvement of a cGMP-dependent pathway in the natriuretic peptide-mediated hormonesensitive lipase phosphorylation in human adipocytes. Journal of Biological Chemistry, 278(49), 48617-48626.

286. Senger, D. R., Galli, S. J., Dvorak, A. M., Perruzzi, C. A., Susan Harvey, V. and Dvorak, H. F. 1983. Tumor cells secrete a vascular permeability factor that promotes accumulation of ascites fluid. Science, 219(4587), 983-985.

287. Shao, D., Park, J. E. S. and Wort, S. J. 2011. The role of endothelin-1 in the pathogenesis of pulmonary arterial hypertension. Pharmacological Research, 63(6), 504-511. 
288. Shi, N., Jin, F., Zhang, X., Clinton, S. K., Pan, Z. and Chen, T. 2014. Overexpression of human $\beta$-defensin 2 promotes growth and invasion during esophageal carcinogenesis. Oncotarget, 5(22), 11333-11344.

289. Shimony, A., Eisenberg, M. J., Rudski, L. G., Schlesinger, R., Afilalo, J., Joyal, D., Dragatakis, L., Hirsch, A., Boutet, K., Fox, B. D. and Langleben, D. 2011. Prevalence and impact of coronary artery disease in patients with pulmonary arterial hypertension. American Journal of Cardiology, 108(3), 460-464.

290. Shin, J. Y., Yoon, I. H., Kim, J. S., Kim, B. and Park, C. G. 2009. Vascular endothelial growth factor-induced chemotaxis and IL-10 from T cells. Cellular Immunology, 256(1-2), 72-78.

291. Shinde, A. V. and Frangogiannis, N. G. 2014. Fibroblasts in myocardial infarction: a role in inflammation and repair. J Mol Cell Cardiol, 0, 74-82.

292. Shouval, D. S., Ouahed, J., Biswas, A., Goettel, J. A., Horwitz, B. H., Klein, C., Muise, A. M. and Snapper, S. B. 2014. Interleukin 10 Receptor Signaling. Adv Immunol, 122, 177-210.

293. Shubin, A. V., Demidyuk, I. V., Komissarov, A. A., Rafieva, L. M. and Kostrov, S. V. 2016. Cytoplasmic vacuolization in cell death and survival. Oncotarget, 7(34), 55863-55889.

294. Singh, P. K., Jia, H. P., Wiles, K., Hesselberth, J., Liu, L., Conway, B. A. D., Greenberg, E. P., Valore, E. V., Welsh, M. J., Ganz, T., Tack, B. F. and McCray, P. B. 1998. Production of $\beta$ defensins by human airway epithelia. Proceedings of the National Academy of Sciences of the United States of America, 95(25), 14961-14966.

295. Singh, U., Devaraj, S., Dasu, M. R., Ciobanu, D., Reusch, J. and Jialal, I. 2006. C-Reactive protein decreases interleukin-10 secretion in activated human monocyte-derived macrophages via inhibition of cyclic AMP production. Arteriosclerosis, Thrombosis, and Vascular Biology, 26(11), 2469-2475.

296. Skrule, J. 2018. Potenciāli zaudētie mūža gadi Latvijā 2017. gadā. Slimību profilakses un kontroles centrs.

297. Skvorak, J. P., Nazian, S. J. and Dietz, J. R. 199). Endothelin acts as a paracrine regulator of stretch-induced atrial natriuretic peptide release. Am J Physiol, 269(5), 1093-1098.

298. Skvorak, J. P., Sutton, E. T., Rao, P. S. and Dietz, J. R. 1996. Therefore, we have concluded that the anoxia-induced ANP response is mediated by locally produced ET, which, in turn, stimulates the production of prostaglandins. Prostaglandins appear to be responsible for the increased ANP secretion rate. Am J Physiol, 271(1), 237-243.

299. Small, A., Kiss, D., Giri, J., Anwaruddin, S., Siddiqi, H., Guerraty, M., Chirinos, J. A., Ferrari G. and Rader, D. J. 2017. Biomarkers of Calcific Aortic Valve Disease. Arterioscler Thromb Vasc Biol, 37(4), 623-632.

300. Smith, D. A., Irving, S. D., Sheldon, J., Cole, D. and Kaski, J. C. 2001. Serum levels of the antiinflammatory cytokine interleukin-10 are decreased in patients with unstable angina. Circulation, 104(7), 746-749.

301. Soini, Y., Paakko, P. and Lehto, V. P. 1998. Histopathological evaluation of apoptosis in cancer. American Journal of Pathology, 153(4), 1041-1053.

302. Štāle, M., Skrule, J. and Rožkalne, G. 2018. Pārskats par Latvijas iedzīvotāju veselību 100 gadu periodā. Slimību profilakses un kontroles centrs.

303. Stefanini, M., de Martino, C. and Zamboni, L. 1967. Fixation of Ejaculated Spermatozoa for Electron Microscopy. Nature, 216, 173-174.

304. Steiner, J. L. and Lang, C. H. 2017. Etiology of alcoholic cardiomyopathy: mitochondria, oxidative stress and apoptosis. Nt J Biochem Cell Biol., 89, 125-135.

305. Stewart, B. F., Siscovick, D., Lind, B. K., Gardin, J. M., Gottdiener, J. S., Smith, V. E., Kitzman, D. W. and Otto, C. M. 1997. Clinical factors associated with calcific aortic valve disease. Journal of the American College of Cardiology, 29(3), 630-634. 
306. Stumpf, C., Lehner, C., Yilmaz, A., Daniel, W. G. and Garlichs, C. D. 2003. Decrease of serum levels of the anti-inflammatory cytokine interleukin-10 in patients with advanced chronic heart failure. Clinical Science, 105(1), 45-50.

307. Szekely, Y. and Arbel, Y. 2018. A Review of Interleukin-1 in Heart Disease: Where Do We Stand Today? Cardiology and Therapy, 7(1), 25-44.

308. Tabima, D. M., Frizzell, S. and Gladwin, M. T. 2012. Reactive oxygen and nitrogen species in pulmonary hypertension. In Free Radical Biology and Medicine (Vol. 52, Issue 9). https://doi.org/10.1016/j.freeradbiomed.2012.02.041.

309. Takahashi, M. 2015. Role of Innate Immune System in Inflammation and Cardiac Remodeling After Myocardial Infarction. Current Vascular Pharmacology, 13(1), 20-25.

310. Talman, V. and Ruskoaho, H. 2016. Cardiac fibrosis in myocardial infarction - from repair and remodeling to regeneration. Cell and Tissue Research, 365(3), 563-581.

311. Tammela, T., Enholm, B., Alitalo, K. and Paavonen, K. 2005. The biology of vascular endothelial growth factors. Cardiovascular Research, 65(3), 550-563.

312. Teibe, U. and Berķis, U. 2001. Daži neparametriskās statistikas lietojumi. In Varbūtību teorijas un matemātiskās statistikas elementi medicinnas studentiem, 58-70.

313. Thibodeau, J. T. and Drazner, M. H. 2018. The Role of the Clinical Examination in Patients With Heart Failure. JACC: Heart Failure, 6(7), 543-551.

314. Thompson, R. J., Doran, J. F., Jackson, P., Dhillon, A. P. and Rode, J. 1983. PGP 9.5 - a new marker for vertebrate neurons and neuroendocrine cells. Brain Research, 278(1-2), 224-228.

315. Timmers, L., Sluijter, J. P. G., van Keulen, J. K., Hoefer, I. E., Nederhoff, M. G. J., Goumans, M. J., Doevendans, P. A., van Echteld, C. J. A., Joles, J. A., Quax, P. H., Piek, J. J., Pasterkamp, G. and de Kleijn, D. P. V. 2008. Toll-like receptor 4 mediates maladaptive left ventricular remodeling and impairs cardiac function after myocardial infarction. Circulation Research, 102(2), 257-264.

316. Torre-Amione, G., Kapadia, S., Benedict, C., Oral, H., Young, J. B. and Mann, D. L. 1996. Proinflammatory cytokine levels in patients with depressed left ventricular ejection fraction: A report from the studies of left ventricular dysfunction (SOLVD). Journal of the American College of Cardiology, 27(5), 1201-1206.

317. Tota, B., Angelone, T. and Cerra, M. C. 2014. The surging role of Chromogranin A in cardiovascular homeostasis. 2(August), 1-13.

318. Tota, B., Gentile, S., Pasqua, T., Bassino, E., Koshimizu, H., Cawley, N. X., Cerra, M. C., Loh, Y. P. and Angelone, T. 2012. The novel chromogranin A-derived serpinin and pyroglutaminated serpinin peptides are positive cardiac $\beta$-adrenergic-like inotropes. FASEB Journal, 26(7), $2888-2898$.

319. Travin, M. I. 2017. Current Clinical Applications and Next Steps for Cardiac Innervation Imaging. Current Cardiology Reports, 19(1), 28084596.

320. Troidl, C., Möllmann, H., Nef, H., Masseli, F., Voss, S., Szardien, S., Willmer, M., Rolf, A., Rixe, J., Troidl, K., Kostin, S., Hamm, C. and Elsässer, A. 2009. Classically and alternatively activated macrophages contribute to tissue remodelling after myocardial infarction. Journal of Cellular and Molecular Medicine, 13(9 B), 3485-3496.

321. Turgeman, Y., Levahar, P., Lavi, I., Shneor, A., Colodner, R., Samra, Z., Bloch, L. and Rosenfeld, T. 2006. Adult calcific aortic stenosis and Chlamydia pneumoniae: The role of Chlamydia infection in valvular calcification. Israel Medical Association Journal, 8(7), 464- 468.

322. Turner, N. A., Das, A., Warburton, P., O'Regan, D. J., Ball, S. G. and Porter, K. E. 2009. Interleukin- $1 \alpha$ stimulates proinflammatory cytokine expression in human cardiac myofibroblasts. American Journal of Physiology - Heart and Circulatory Physiology, 297(3), 1117-1127. 
323. Üçeyler, N., Zeller, D., Kahn, A. K., Kewenig, S., Kittel-Schneider, S., Schmid, A., CasanovaMolla, J., Reiners, K. and Sommer, C. 2013. Small fibre pathology in patients with fibromyalgia syndrome. Brain, 136(6), 1857-1867.

324. Van Haelst, P. L., Cohen Tervaert, J. W., Bijzet, J., Baljé-Volkers, C., May, J. F., Langeveld, B. and Gans, R. O. B. 2004. Circulating monocytes in patients with acute coronary syndromes lack sufficient interleukin-10 production after lipopolysaccharide stimulation. Clinical and Experimental Immunology, 138(2), 364-368.

325. Verma, S., Garikipati, V., Krishnamurthy, P., Schumacher, S., Grisanti, L., Cimini, M., Cheng, Z., Khan, M., Yue, Y., Benedict, C., Truongcao, M., Rabinowitz, J., Goukassian, D., Tilley, D., Koch, W. and Kishore, R. 2018. Interleukin 10 Inhibits Bone Marrow Fibroblast Progenitor Cellmediated Cardiac Fibrosis in Pressure Overloaded Myocardium. Circulation, 136(10), 940-953.

326. Verma, S. K., Garikapiti, V. N. S., Krishnamurthy, P., Barefield, D., Singh, N., Gupta, R., Lambers, E., Thal, M., Mackie, A., Hoxha, E., Ramirez, V., Qin, G., Sadayappan, S., Ghosh, A. and Kishore, R. 2013. IL 10 Treatment Attenuates Pressure Overload-Induced Hypertrophic Remodeling and Improves Heart Function via STAT3 Dependent Inhibition of NFkB. Circulation, 126(4), 418-429.

327. Volpe, M., Carnovali, M. and Mastromarino, V. 2016. The natriuretic peptides system in the pathophysiology of heart failure: From molecular basis to treatment. Clinical Science, 130(2), 57-77.

328. Wallby, L., Janerot-Sjöberg, B., Steffensen, T. and Broqvist, M. 2002. T lymphocyte infiltration in non-rheumatic aortic stenosis: A comparative descriptive study between tricuspid and bicuspid aortic valves. Heart, 88(4), 348-351.

329. Wang, X., Guo, Z., Ding, Z. and Mehta, J. L. 2018. Inflammation, autophagy, and apoptosis after myocardial infarction. Journal of the American Heart Association, 7(9).

330. Weber, K. T., Sun, Y., Bhattacharya, S. K., Ahokas, R. A. and Gerling, I. C. 2013. Myofibroblastmediated mechanisms of pathological remodelling of the heart. Nature Reviews Cardiology, 10(1), 15-26.

331. Westphal, E., Chen, L., Pilowski, C., Koch, S., Ebelt, H., Müller-Werdan, U., Werdan, K. and Loppnow, H. 2007. Endotoxin-activated cultured neonatal rat cardiomyocytes express functional surface-associated interleukin-1 $\alpha$. Journal of Endotoxin Research, 13(1), 25-34.

332. Whelan, R. S., Kaplinskiy, V. and Kitsis, R. N. 2010. Cell Death in the Pathogenesis of Heart Disease: Mechanisms and Significance. Annual Review of Physiology, 72(1), 19-44.

333. Wickramasinghe, S. R. and Patel, V. V. 2013. Local Innervation and Atrial Fibrillation. Circulation, 128, 1566-1575.

334. Wilkins, E., Wilson, L., Wickramasinghe, K., Bhatnagar, P., Leal, J., Luengo-Fernandez, R., Burns, R., Rayner, M. and Townsend, N. 2017. European Cardiovascular Disease Statistics 2017 edition. European Heart Network, Brussels, 192.

335. Willerson, J. T. and Ridker, P. M. 2004. Inflammation as a cardiovascular risk factor. Circulation, 109(21 SUPPL.), 2-10.

336. Wilson, S. S., Wiens, M. E. and Smith, J. G. 2013. Antiviral Mechanisms of Human Defensins. $J$ Mol Biol, 425(24), 4965-4980.

337. Winter, J. and Wenghoefer, M. 2012. Human defensins: Potential tools for clinical applications. Polymers, 4(1), 691-709.

338. World Health Organization. 2017. Cardiovascular diseases ( CVDs ). Key Facts What Are the Risk Factors for Cardiovascular Disease?

339. World Health Organization. 2018. Leading causes of death by economy income group. The Top 10 Causes of Death. 
340. Xia, P., Liu, Y. and Cheng, Z. 2016. Signaling Pathways in Cardiac Myocyte Apoptosis. BioMed Research International, 2016, 1-22.

341. Xu, D., Zhang, B., Liao, C., Zhang, W., Wang, W., Chang, Y. and Shao, Y. 2016. Human betadefensin 3 contributes to the carcinogenesis of cervical cancer via activation of NF- $\kappa \mathrm{B}$ signaling. Oncotarget, 7(46), 75902-75913.

342. Xu, X. H., Xu, J., Xue, L., Cao, H. L., Liu, X. and Chen, Y. J. 2011. VEGF attenuates development from cardiac hypertrophy to heart failure after aortic stenosis through mitochondrial mediated apoptosis and cardiomyocyte proliferation. Journal of Cardiothoracic Surgery, 6(1), 54.

343. Yanagi, S., Ashitani, J., Imai, K., Kyoraku, Y., Sano, A., Matsumoto, N. and Nakazato, M. 2007. Significance of human $\beta$-defensins in the epithelial lining fluid of patients with chronic lower respiratory tract infections. Clinical Microbiology and Infection, 13(1), 63-69.

344. Yanagisawa, M., Kurihara, H., Kimura, S., Tomobe, Y., Kobayashi, M., Mitsui, Y., Yazaki, Y., Goto, K. and Masaki, T. 1988. A novel potent vasoconstrictor peptide produced by vascular endothelial cells. Nature, 332(6163), 411-415.

345. Yang, Z., Zingarelli, B. and Szabó, C. 2000. Crucial role of endogenous interleukin-10 production in myocardial ischemia/reperfusion injury. Circulation, 101(9), 1019-1026.

346. Yip, H., Youssef, A. A., Chang, L., Yang, C., Sheu, J., Chua, S., Yeh, K., Lee, F., Wu, C. and Hang, C. 2007. Association of Interleukin-10 Level With Increased 30-Day Mortality in Patients With ST-Segment Elevation. Circulation Journal, 71(July), 1086-1091.

347. Yu, D. S., Hsieh, D. S. and Chang, S. Y. 2003. Modulation of prostate carcinoma cell growth and apoptosis by chromogranin A. Journal of Urology, 170(5), 2031-2035.

348. Zakynthinos, E. and Pappa, N. 2009. Inflammatory biomarkers in coronary artery disease. Journal of Cardiology, 53(3), 317-333.

349. Zarrouk-Mahjoub, S., Zaghdoudi, M., Amira, Z., Chebi, H., Khabouchi, N., Finsterer, J., Mechmeche, R. and Ghazouani, E. 2016. Pro- and anti-inflammatory cytokines in post-infarction left ventricular remodeling. International Journal of Cardiology, 221, 632-636.

350. Zhang, B., Bailey, W. M., Braun, K. J. and Gensel, J. C. 2015. Age decreases macrophage IL-10 expression: implications for functional recovery and tissue repair in spinal cord injury. Exp Neurol, 273, 83-91.

351. Zhang, D., Lavaux, T., Sapin, R., Lavigne, T., Castelain, V., Aunis, D., Metz-Boutigue, M. H. and Schneider, F. 2009. Serum concentration of chromogranin A at admission: An early biomarker of severity in critically ill patients. Annals of Medicine, 41(1), 38-44.

352. Zhao, X. S., Pan, W., Bekeredjian, R. and Shohet, R. V. 2006. Endogenous endothelin-1 is required for cardiomyocyte survival in vivo. Circulation, 114(8), 830-837.

353. Ziegler, K. A., Ahles, A., Wille, T., Kerler, J., Ramanujam, D. and Engelhardt, S. 2018. Local sympathetic denervation attenuates myocardial inflammation and improves cardiac function after myocardial infarction in mice. Cardiovascular Research, 114(2), 291-299. 


\section{Pateicības}

Vislielākā pateicība manai darba vadītājai Dr. habil. med. profesorei Mārai Pilmanei par iedrošinājumu, ārkārtīgi lielo atbalstu, ieguldīto laiku un vērtīgajiem padomiem visa pētniecības procesa un darba rakstīšanas gaitā.

Ļoti pateicos otram darba vadītājam Dr. habil. med. AS profesoram Romanam Lācim par atbalstu un padomiem studiju laikā.

Vēlos izteikt lielu pateicību Rīgas Stradiņa universitātes Anatomijas un antropoloǵijas institūta Morfolog̣ijas laboratorijas laborantei Natālijai Morozai par ieguldīto darbu preparātu sagatavošanā. Paldies arī Anatomijas un antropologijijas institūta inženieriem Jānim Krievam un Pēterim Ronim par palīdzību mikrofotogrāfiju sagatavošanā, Anatomijas un antropolog̣ijas institūta biroja vadītājām Elitai Jakovickai un Daigai Enkuzenai, RSU Ķirurǵijas katedras sekretārei Valentīnai Soboḷevai par sadarbības koordinēšanu, kā arī citiem RSU darbiniekiem par pozitīvo attieksmi un praktisko palīdzību studiju laikā.

Pateicos dr. Emīlam Šmitiṇam par laipni atvēlēto iedzimto sirdskaišu audu materiālu.

No sirds pateicos Dr. med. asociētajam profesoram Uldim Strazdiṇam par uzmundrinājumu, padomiem un praktisko atbalstu studiju procesā. Liels paldies Paula Stradiņa Klīniskās universitātes slimnīcas agrākās 16. nodaḷas personālam un 1. operāciju bloka operāciju māsām par atsaucību un palīdzību pētîjuma materiāla iegūšanā.

Pateicos Rīgas Stradiṇa universitātei par iespēju studēt un Doktorantūras nodaḷai par atsaucību un palīdzību studiju procesā. Pateicos arī mana promocijas darba recenzentiem par tā izvērtēšanu, sniegtajiem ieteikumiem, ieguldīto darbu un laiku.

Sirsnīgs paldies vīram Robertam un dēlam Viesturam par pacietību un sapratni, kā arī par atbalstu visā studiju un promocijas darba tapšanas gaitā, kā arī lūdzu piedošanu par atņemto kopā būšanas laiku.

Visbeidzot sirsnīgi pateicos visiem saviem draugiem un kolēgiem, īpaši Ievai Grudzinskai-Elsbergai, Baibai Vernerei, Indrai Bojkovskai, Gitai Tauriņai, Andrim Finkam un Indrai Viḷumsonei, par psihologiisko atbalstu un uzmundrinājumu. 
Pielikumi 
1. pielikums

Ẽtikas komitejas aț̣aujas

Veidlapa $\mathrm{Nr}, \mathrm{E}-9$ (2)

\section{RSU ETIKAS KOMITEJAS LẼMUMS}

Riga, Drirciema iela 16, LV-1007. Tel. 67409089

Komitejas sastãvs

- Profesors Olaf's Brûver:

2. Profesore Vija Sile

3. Asoc.prof. Santa Purvipa

4. Asociprof. Voidemairs Arnis

5. Profesore Regina Kleina

6. Profesors Guntars Pupelis

7. Asoc.prof. Viesturs Liguts
Kvalifikācija

Dr.theo.

Drphil.

Dr.med.

Dr.biol.

Drmed

Drimed.

Drimed
Nodarbosanẩs

teologs

filozofis

farmakologs

rehabilitologs

patalogs

kirurgs

toksikologs

\begin{tabular}{|c|c|}
\hline Picteikuma iesniedxāis: & $\begin{array}{l}\text { Edite Kulmane, } 4 \text {, studiju gada rexidente } \\
\text { Talikkizglitihas fakultate }\end{array}$ \\
\hline Perijuma nersaukums: & $\begin{array}{l}\text { Iabil prickskamban undu strukturälo izmaipu } \\
\text { diagnostiski prognostiskic markieri dažădu ieguitu } \\
\text { sirdskaißu gadijumos". }\end{array}$ \\
\hline
\end{tabular}

Iesniegð̌anas dafums: 12.05.2014.

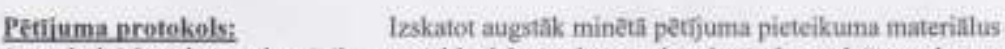

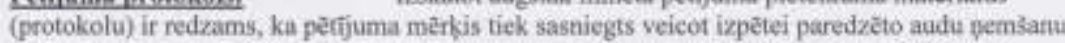
plinveida sirds operâcijas laikã (bez kĩda apdraudejuma pacienta veselibai un dzivibai), to

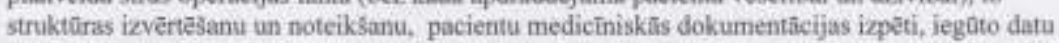
apstrîdi un analīa, kï ari izsakot priekșikumus. Persona (pacientu, dalibnieka) datu aizsardziba,

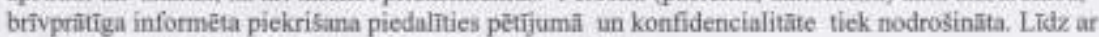
to pieteikums atbilst medicinas pêtjuma êtikas prasibialm.

\section{Izskaidroǩanas formulian: ir}

Pickrỉ̌ana piedalities pétrijumâ: ir

Komiteias lêmums:

piekrist pêtijumam

Komitejas priekçsē̃ēêtâjs Olafs Brôvers Tituls: Dr. miss, prof.

Paraksts

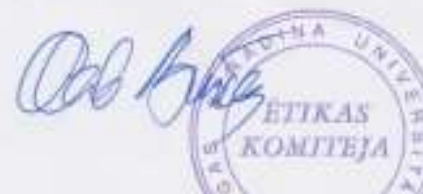

Etikas komitajas sêdes datums. $29,05,2014$ 
1. pielikuma turpinājums

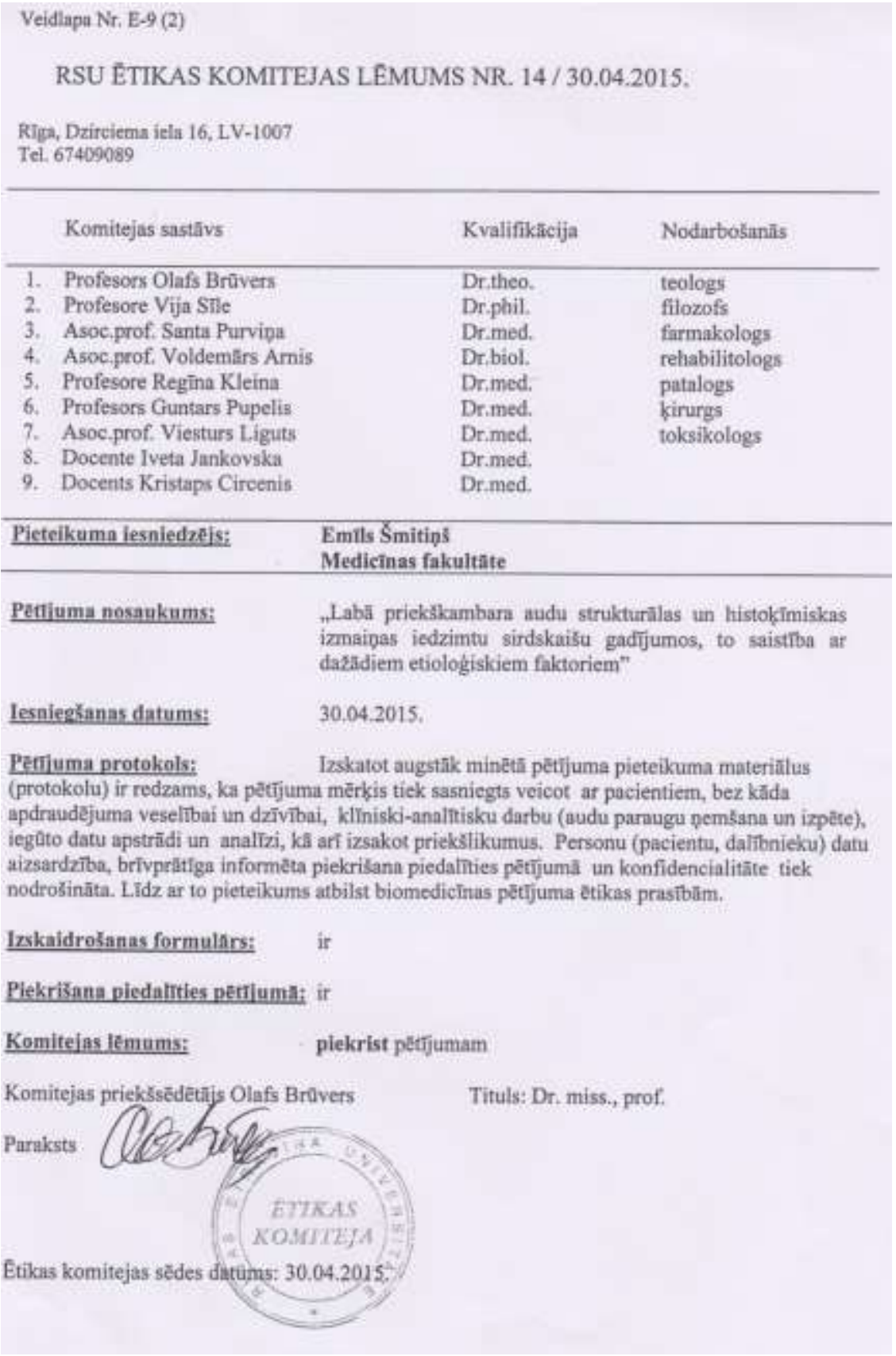




\section{Mikrofotogrāfijas}

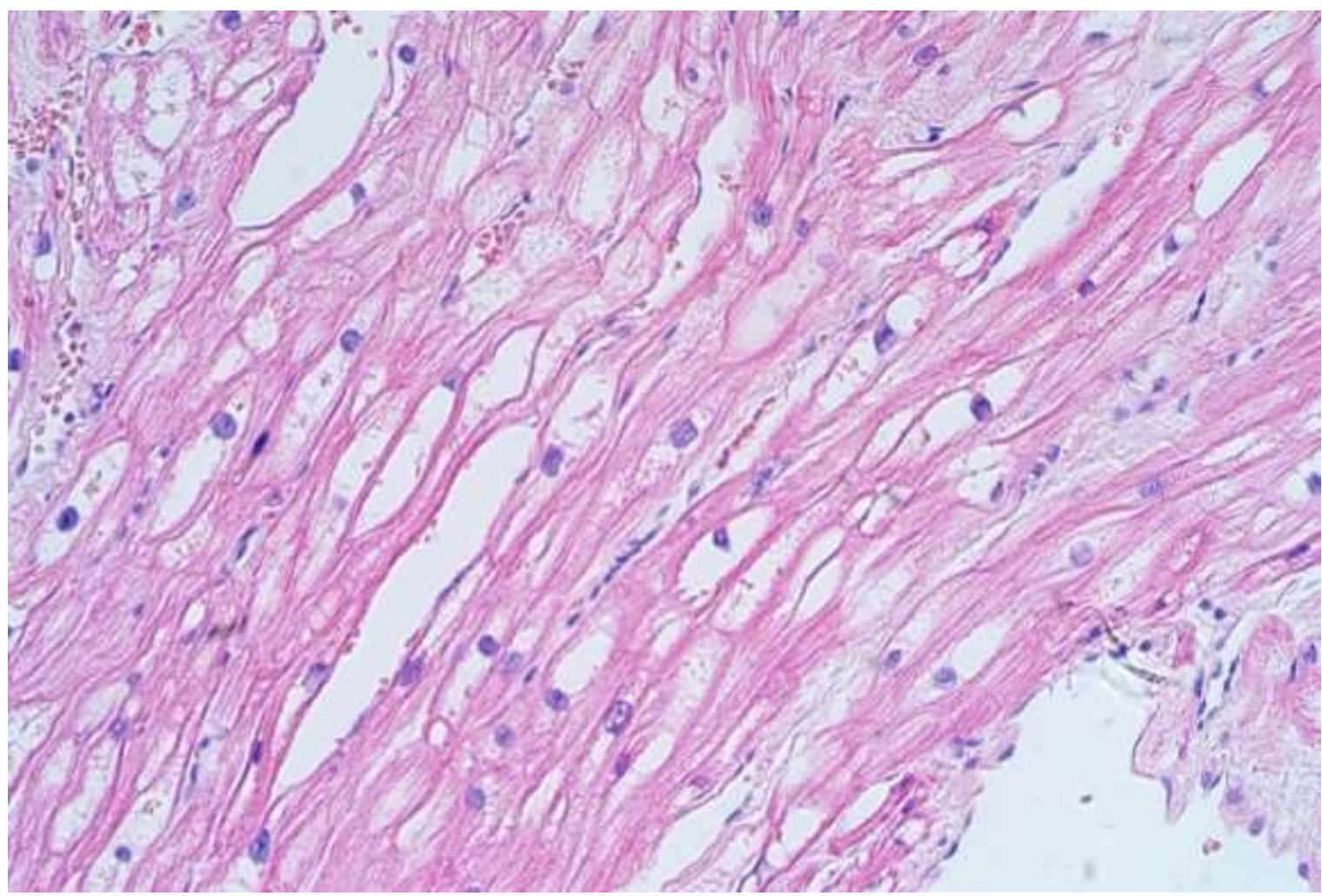

1. attēls. Kardiomiocītu vakuolizācija zonās ap kodoliem labā priekškambara audos 63 gadus vecam pacientam ar $\mathrm{KSS}(\mathrm{He} / \mathrm{Eo}, \times 200)$

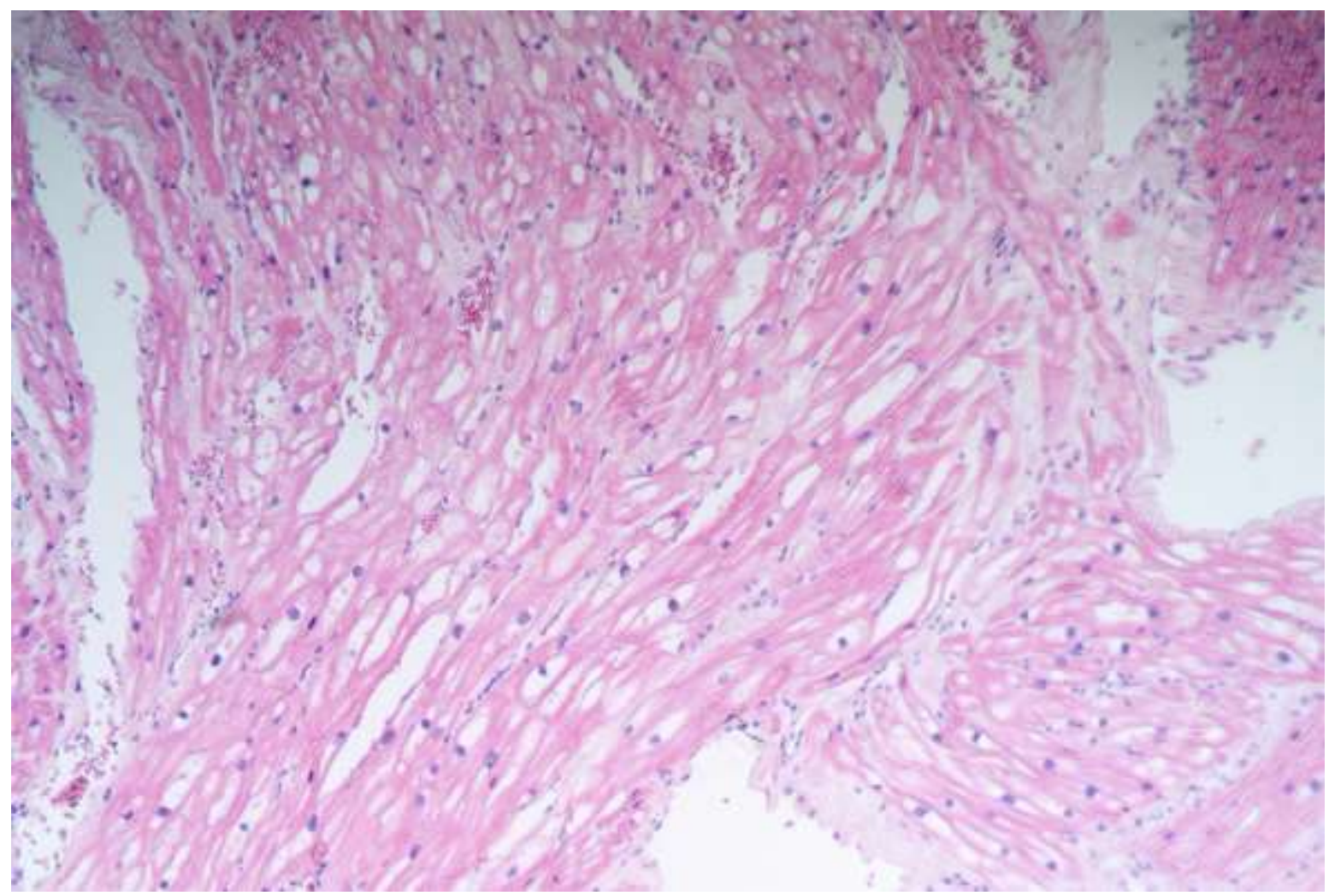

2. attēls. Difūza kardiomiocītu vakuolizācija labā priekškambara audos 63 gadus vecam pacientam ar KSS $(\mathrm{He} / \mathrm{Eo}, \times 100)$ 


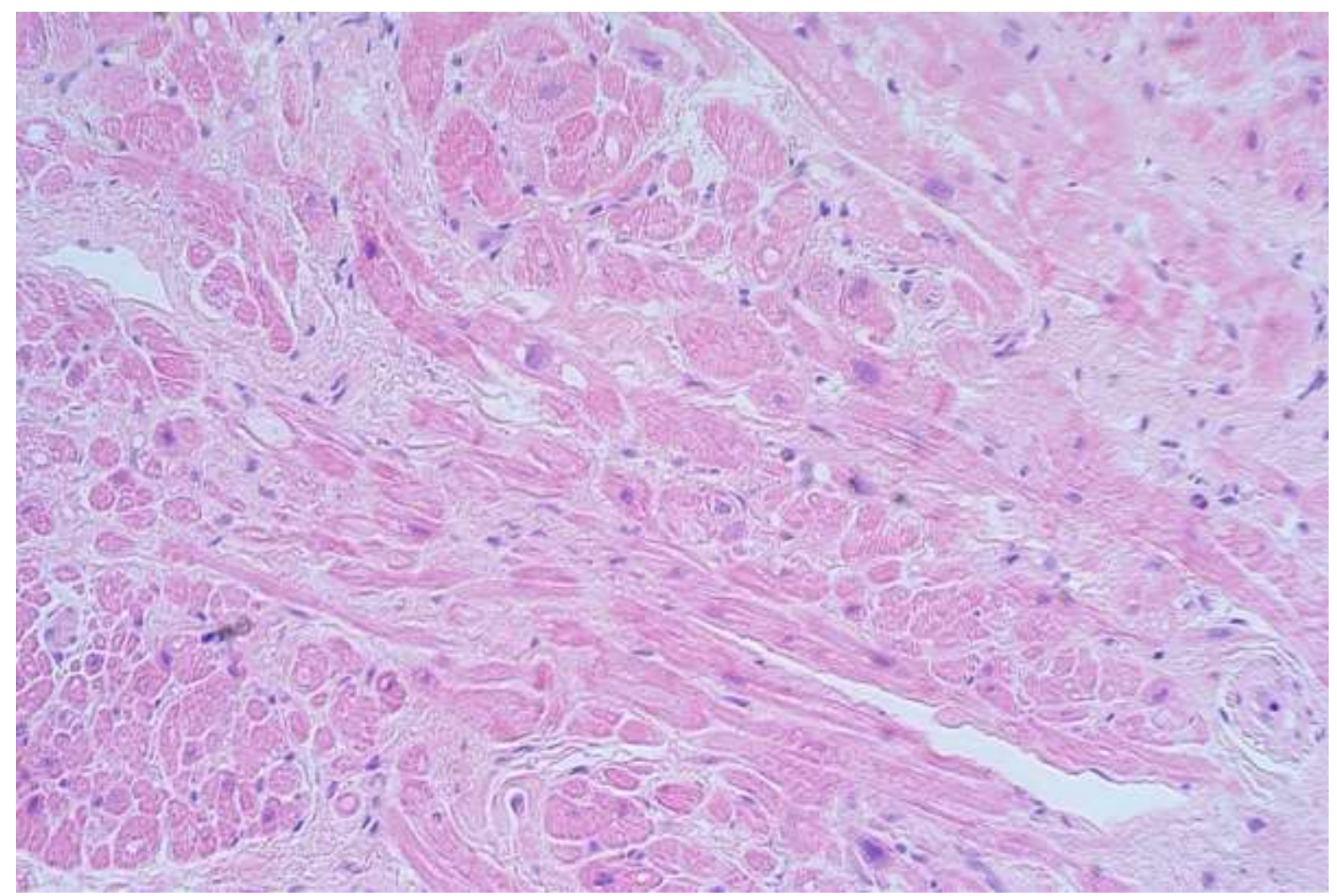

3. attēls. Mazizteikta kardiomiocītu vakuolizācija labā priekškambara audos 70 gadu vecam pacientam ar AoV stenozi $(\mathrm{He} / \mathrm{Eo}, \times 200)$

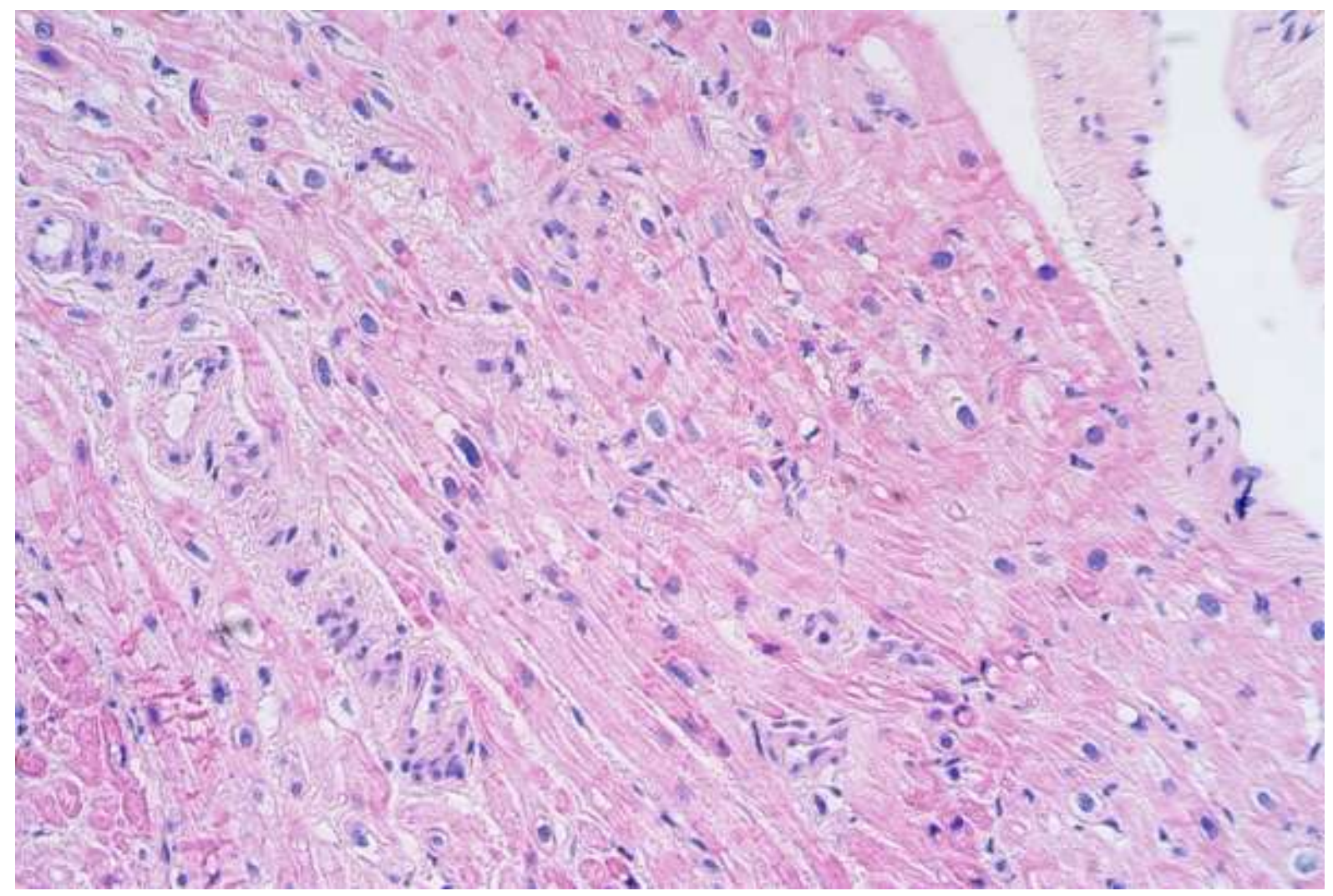

4. attēls. Dažāda izmēra kardiomiocītu kodoli labā priekškambara audos

57 gadus vecam pacientam ar $\mathrm{KSS}(\mathrm{He} / \mathrm{Eo}, \times 200)$ 


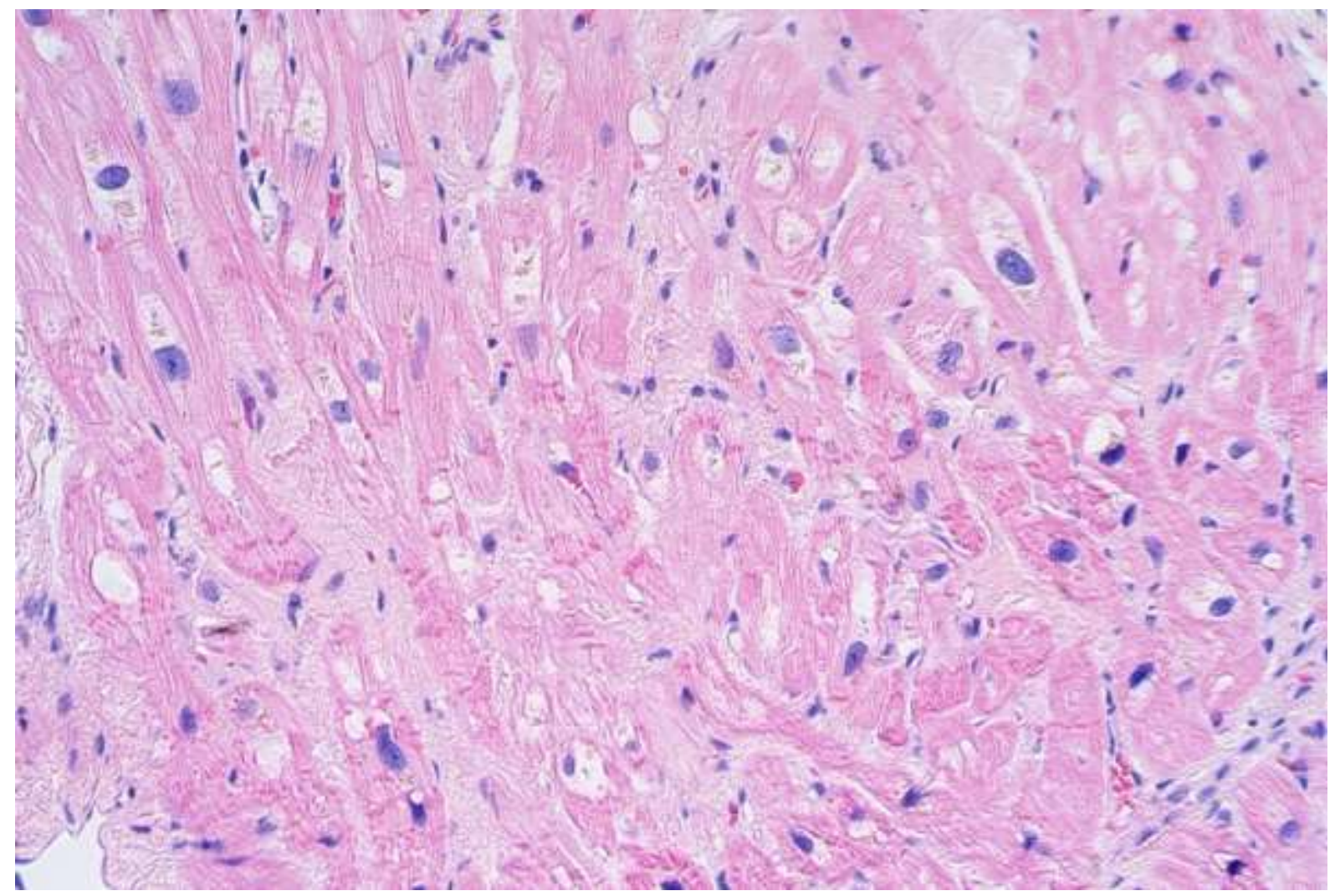

5. attēls. Lieli kodoli labā priekškambara kardiomiocītos

78 gadus vecam pacientam ar $\mathrm{KSS}(\mathrm{He} / \mathrm{Eo}, \times 200)$

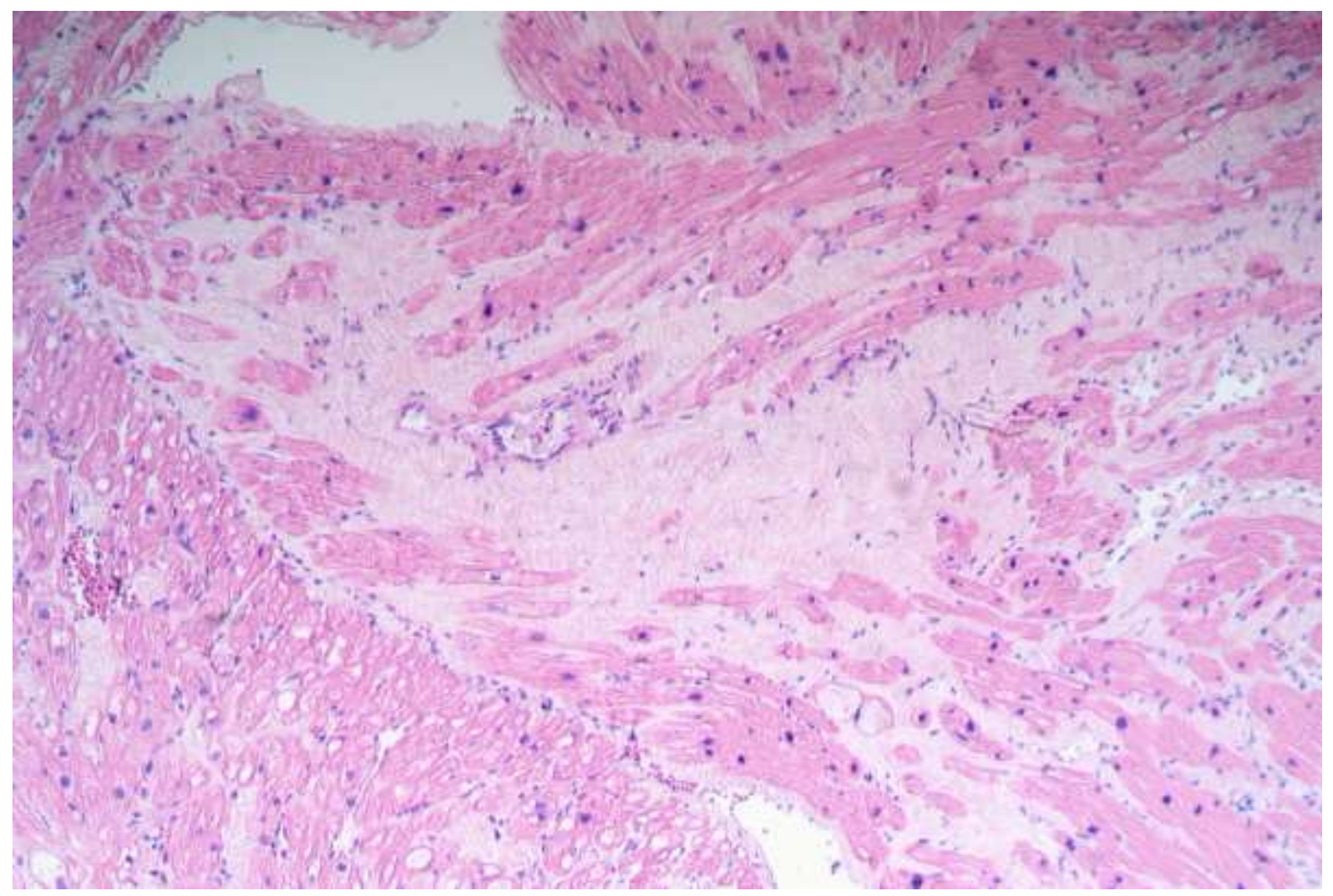

6. attēls. Saistaudu ieaugšana labā priekškambara miokardā 63 gadus vecam pacientam ar KSS $(\mathrm{He} / \mathbf{E o}, \times \mathbf{1 0 0})$ 


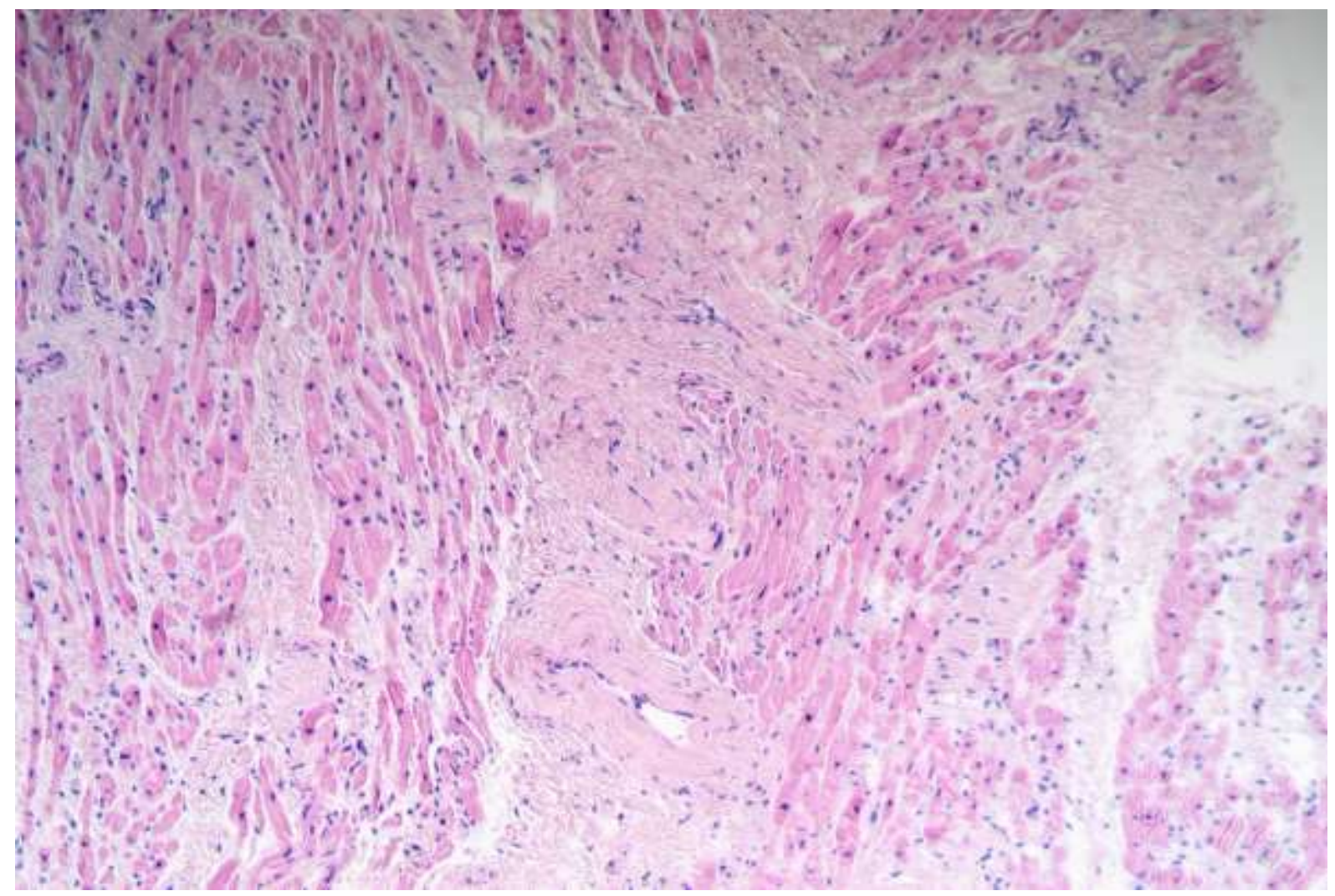

7. attēls. Sklerotiski asinsvadi labā priekškambara audos $\mathbf{7 4}$ gadus vecam pacientam ar deǵeneratīvu AoV stenozi $(\mathrm{He} / \mathbf{E o}, \times \mathbf{1 0 0})$

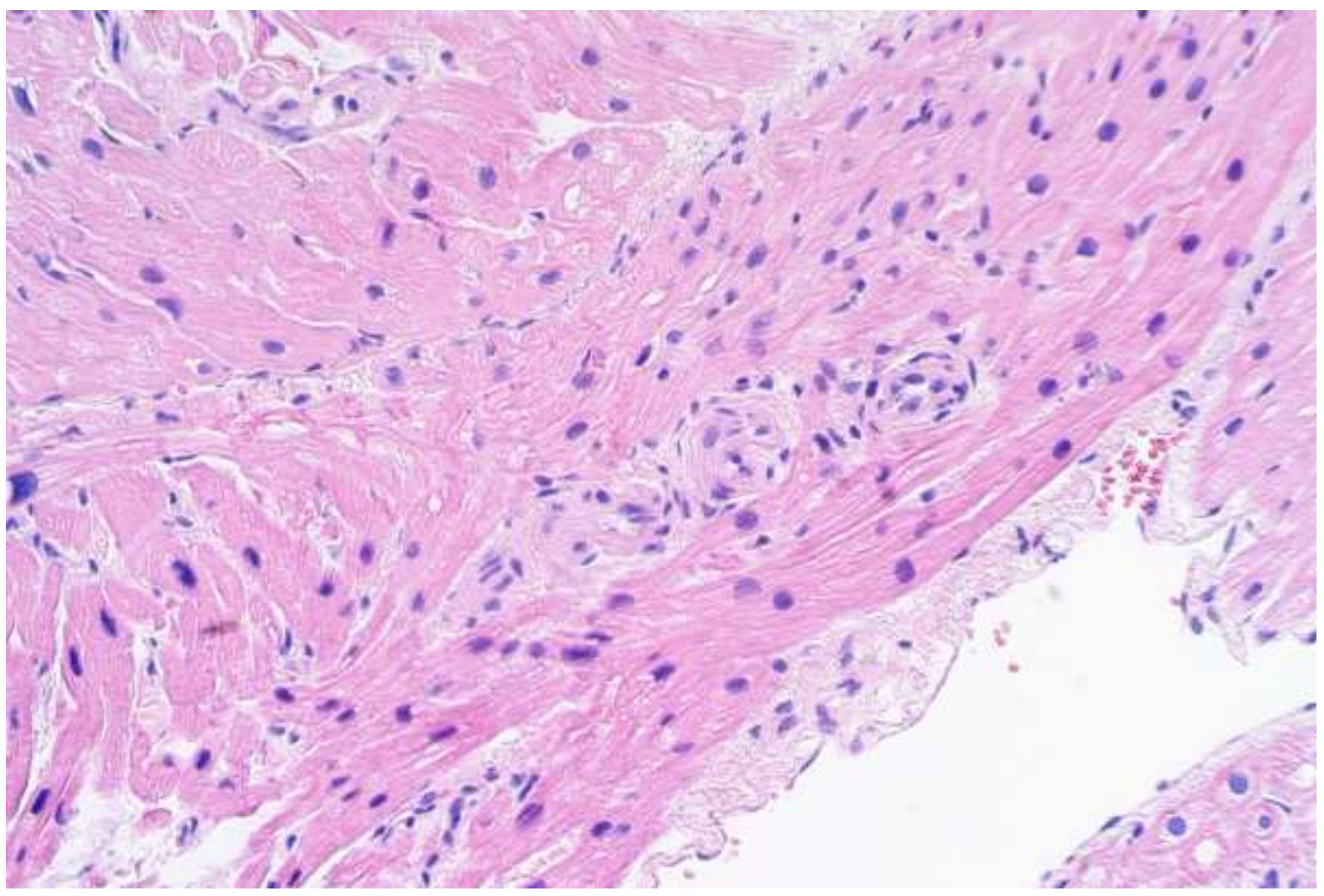

8. attēls. Sklerotiski asinsvadi labā priekškambara audos 55 gadus vecam pacientam ar KSS $(\mathrm{He} / \mathrm{Eo}, \times \mathbf{2 0 0})$ 


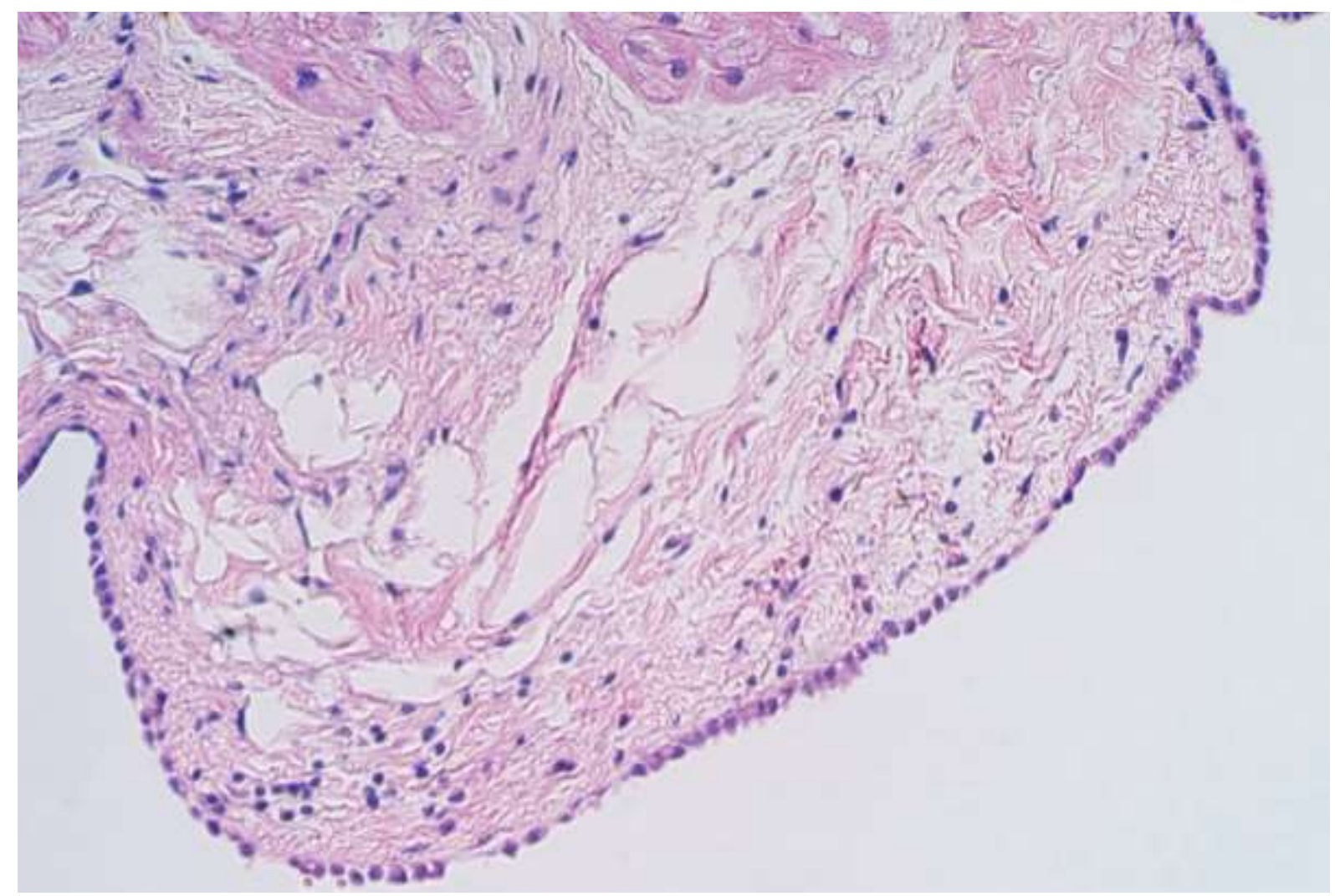

9. attēls. Kubiskas formas epikarda epitēlija šūnas labā priekškambara audos 55 gadus vecam pacientam ar KSS $(\mathrm{He} / \mathrm{Eo}, \times 200)$

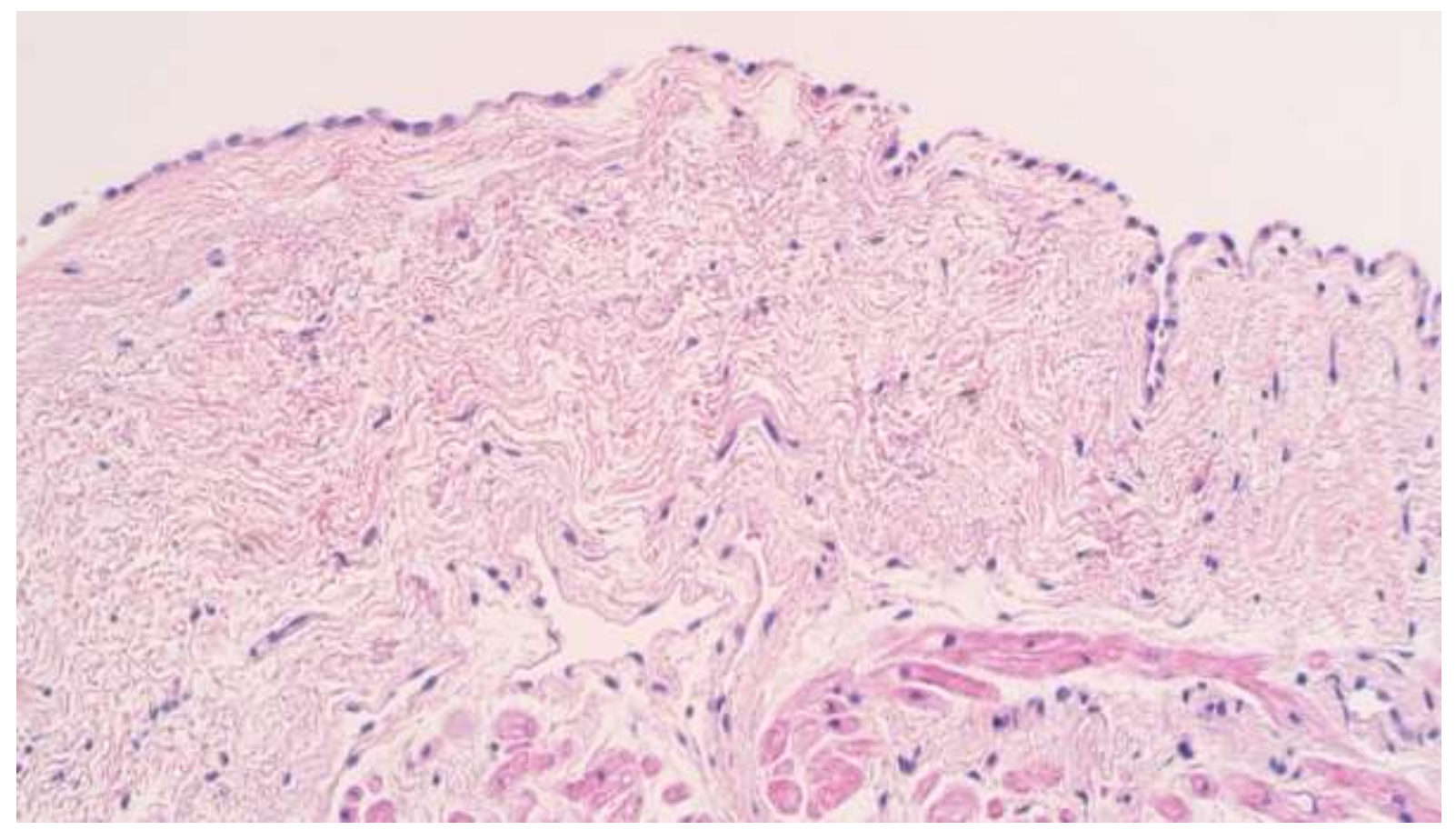

10. attēls. Kubiskas formas epikarda epitēlija šūnas labā priekškambara audos 74 gadus vecam pacientam ar degeneratīvu AoV stenozi $(\mathrm{He} / \mathbf{E o}, \times 200)$ 


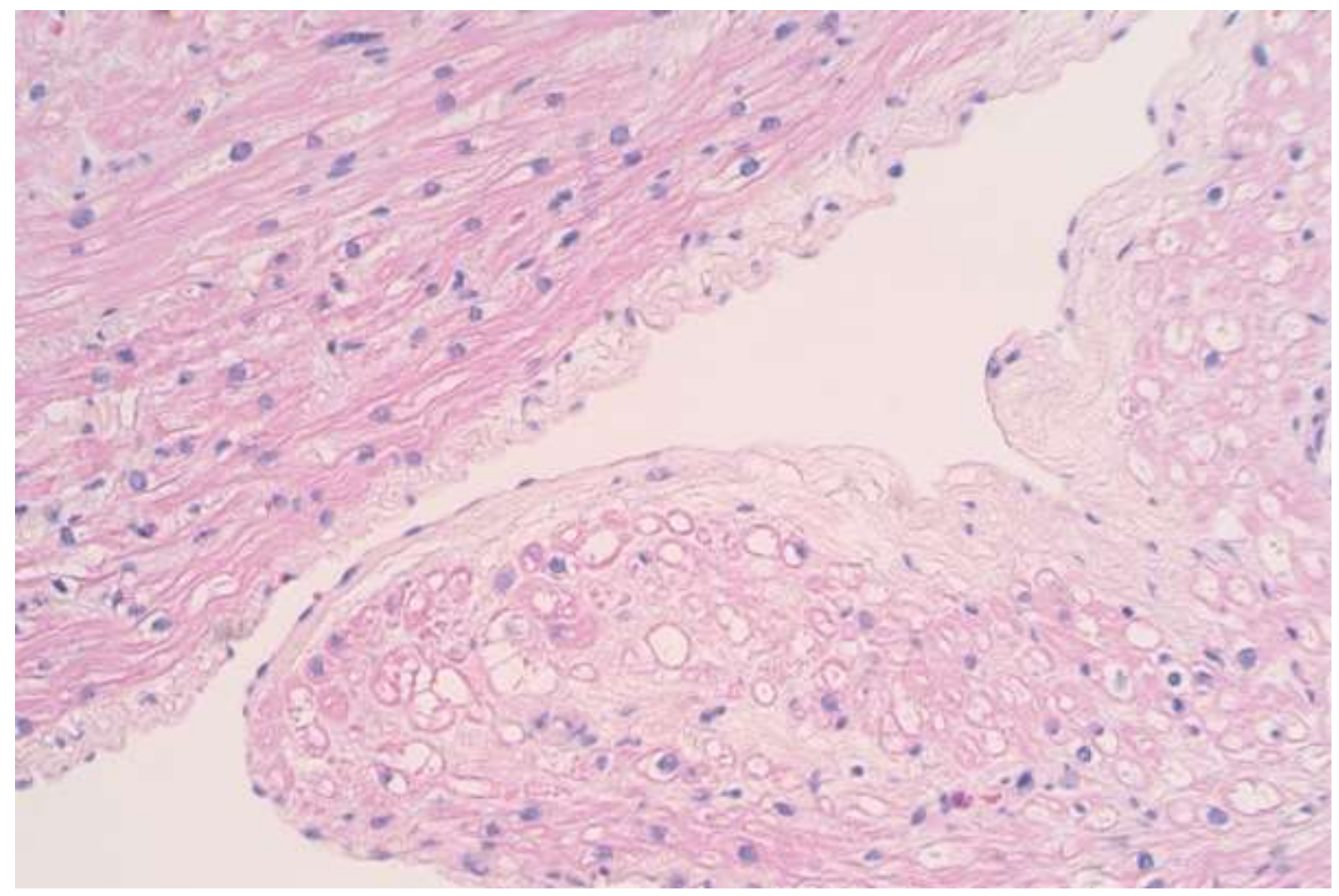

11. attēls. Plakanas formas endokarda endotēlija šūnas labā priekškambara audos 56 gadus vecam pacientam ar $\mathrm{KSS}(\mathrm{He} / \mathrm{Eo}, \times 200)$

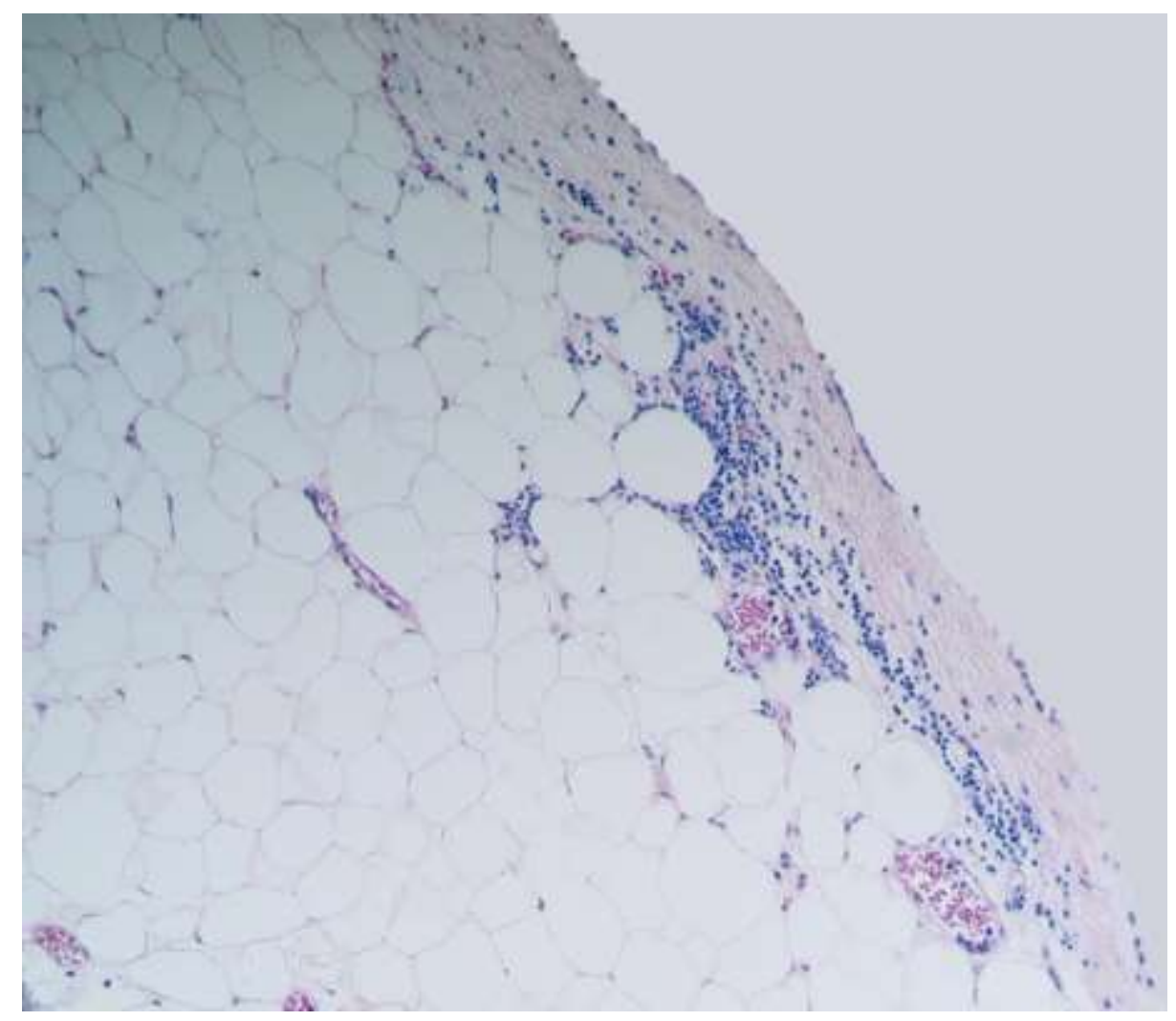

12. attēls. Iekaisuma šūnu infiltrācija epikardā labā priekškambara audos 56 gadus vecam pacientam ar $\mathrm{KSS}(\mathrm{He} / \mathrm{Eo}, \times 100)$ 


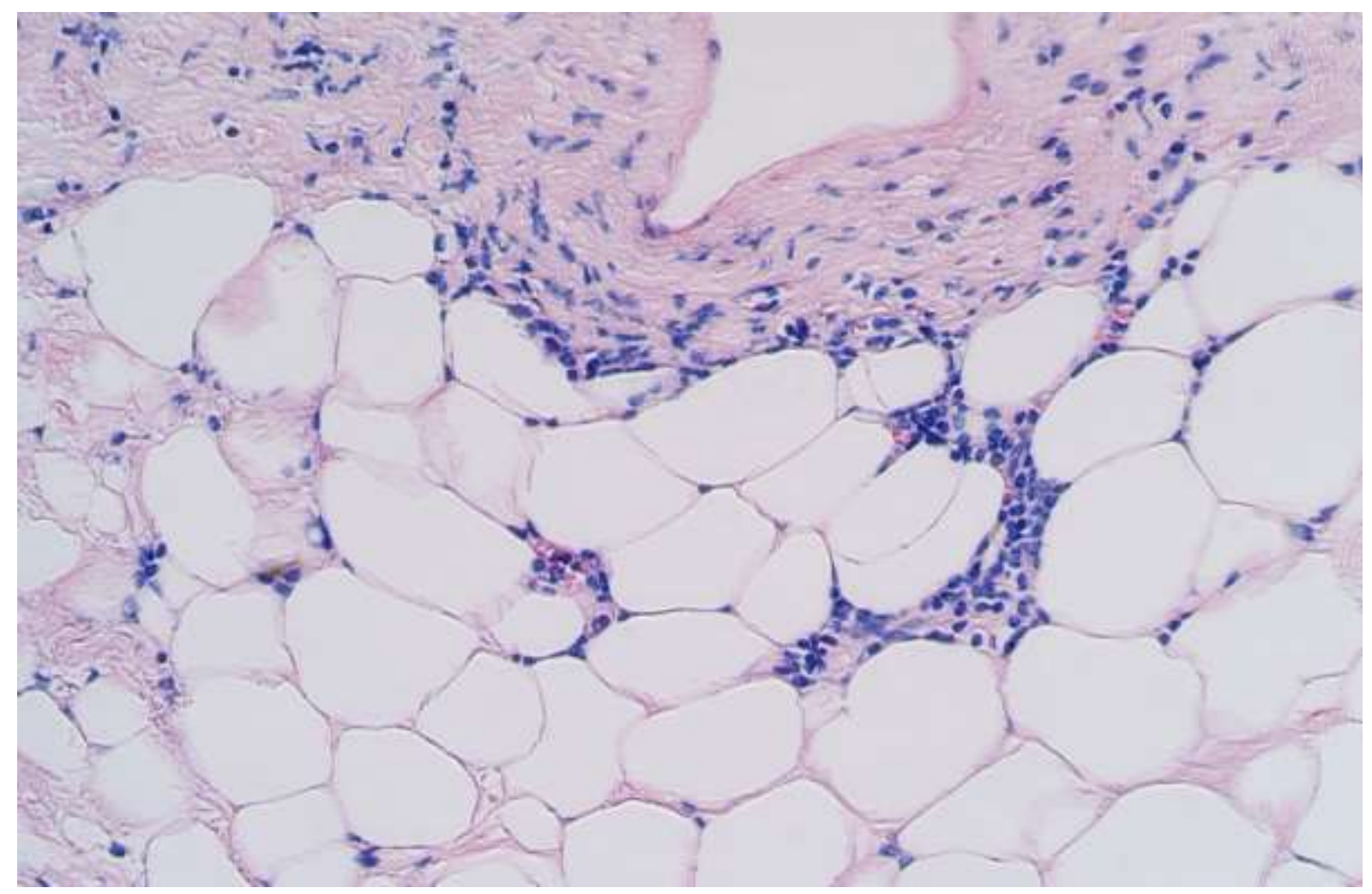

13. attēls. Iekaisuma šūnu infiltrācija epikardā labā priekškambara audos 52 gadus vecam pacientam ar degeneratīvu AoV stenozi $(\mathbf{H e} / \mathbf{E o}, \times 200)$

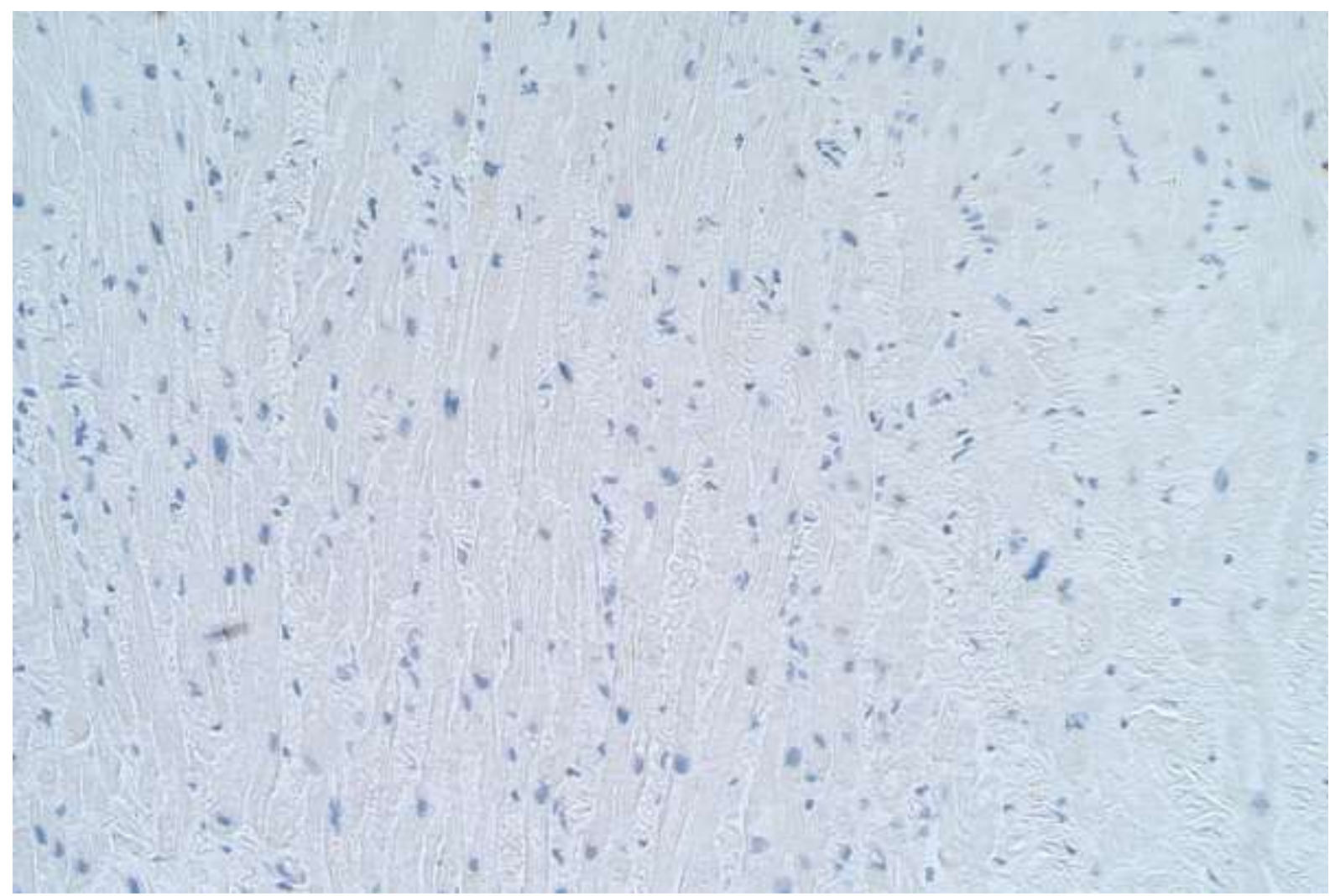

14. attēls. Apoptotisku kardiomiocītu trūkums labā priekškambara miokardā 77 gadus vecam pacientam ar KSS (TUNEL, ×200) 


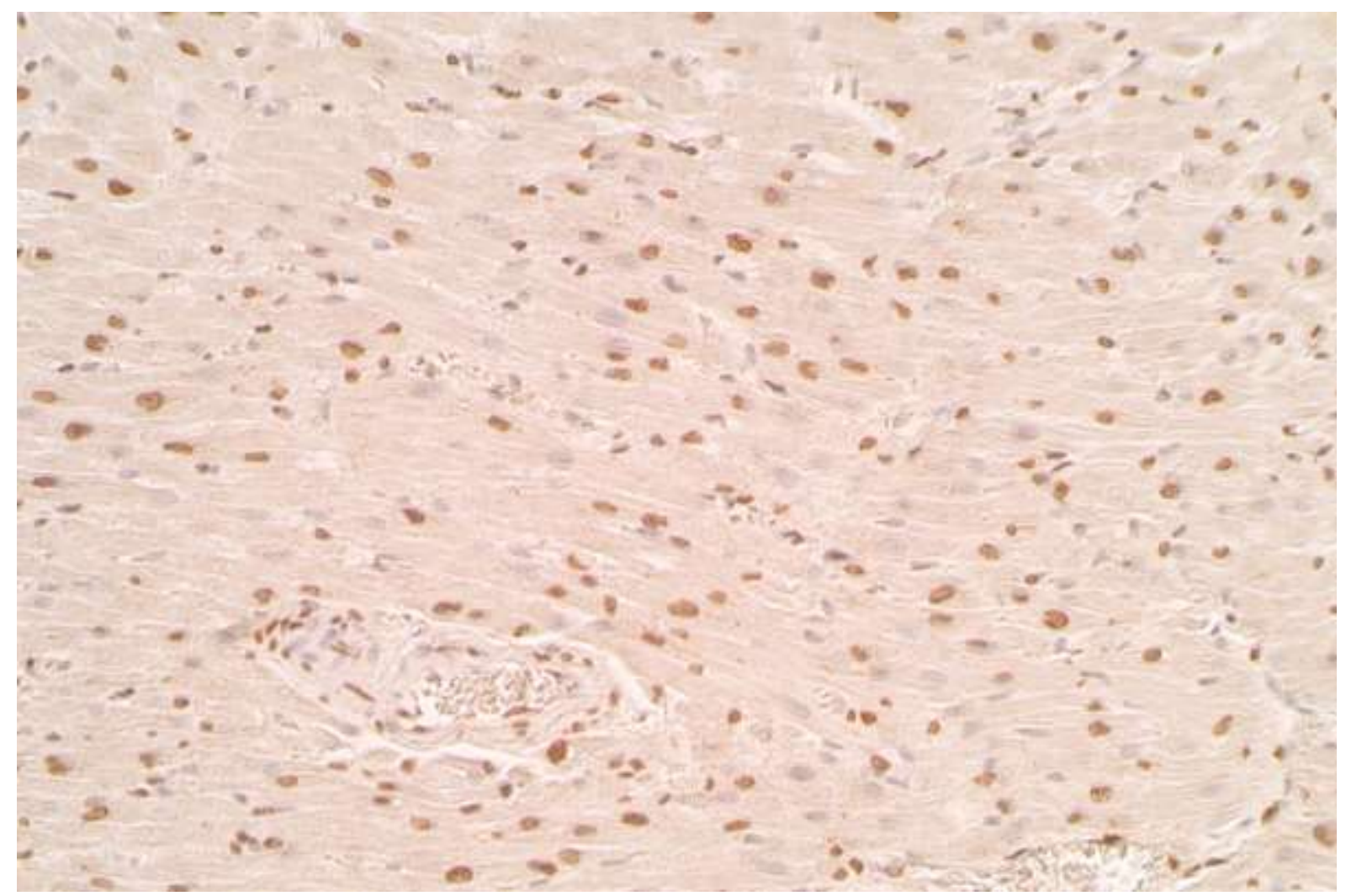

15. attēls. Vidēji daudz apoptotisku kardiomiocītu labā priekškambara miokardā 62 gadus vecam pacientam ar KSS (TUNEL, ×200)

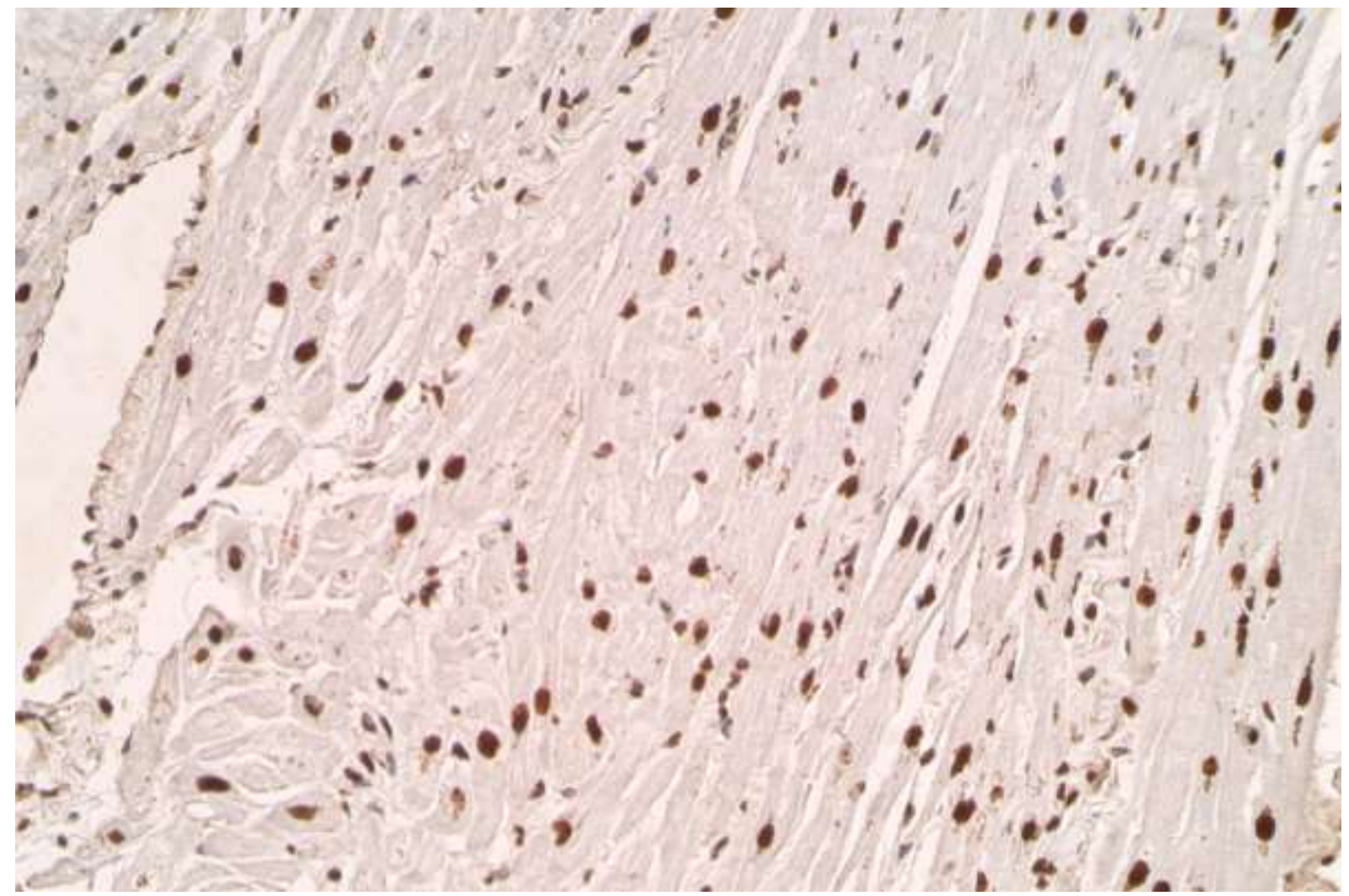

16. attēls. Daudz apoptotisku kardiomiocītu labā priekškambara miokardā 66 gadus vecam pacientam ar KSS (TUNEL, ×200) 


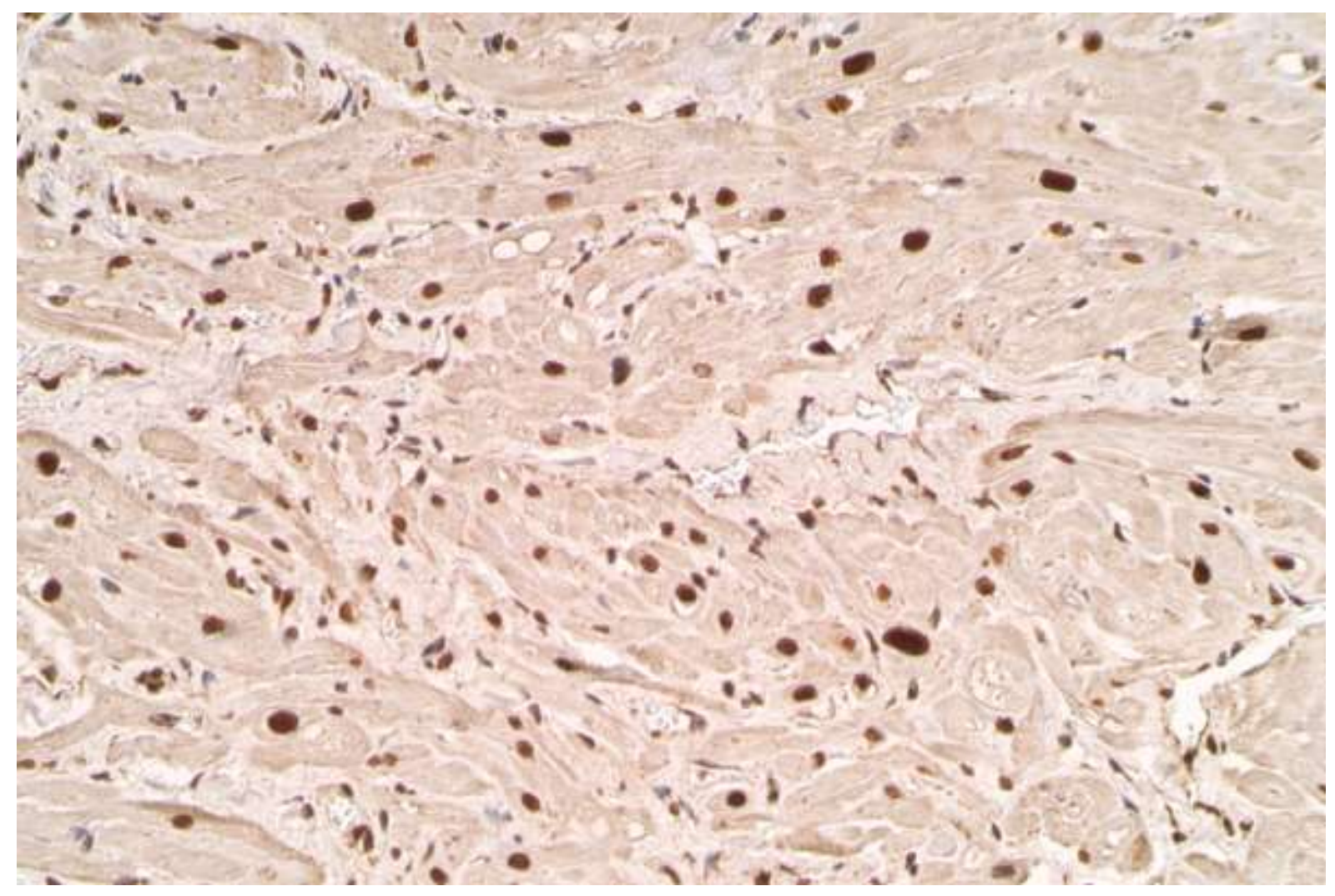

17. attēls. Daudz apoptotisku kardiomiocītu labā priekškambara miokardā 53 gadus vecam pacientam ar degeneneratīvu AoV stenozi (TUNEL, ×200)

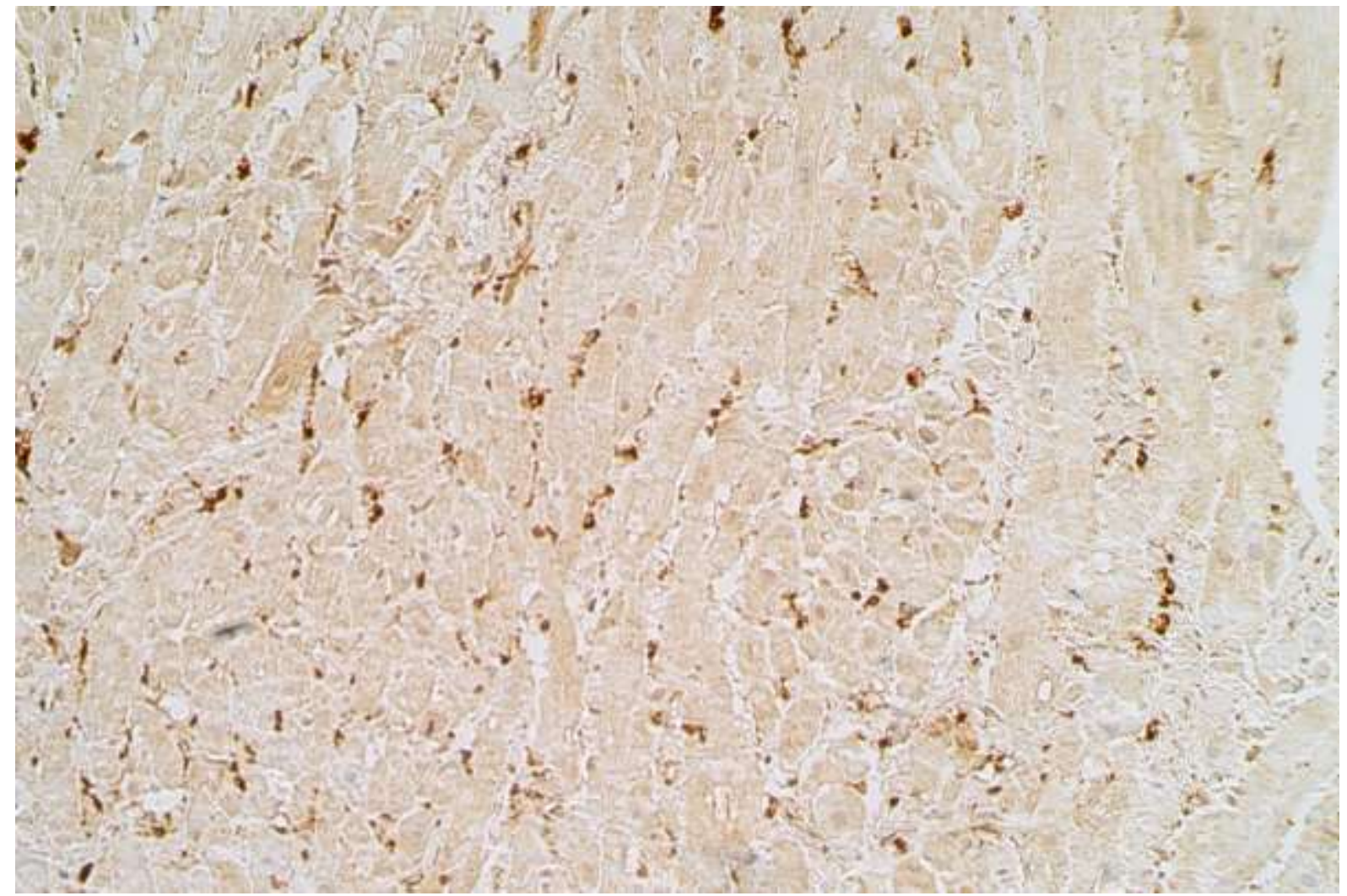

18. attēls. Daudz PGP 9.5 saturošu nervu šḳiedru labā priekškambara audos 66 gadus vecam pacientam ar KSS (PGP 9.5 IMH, ×200) 


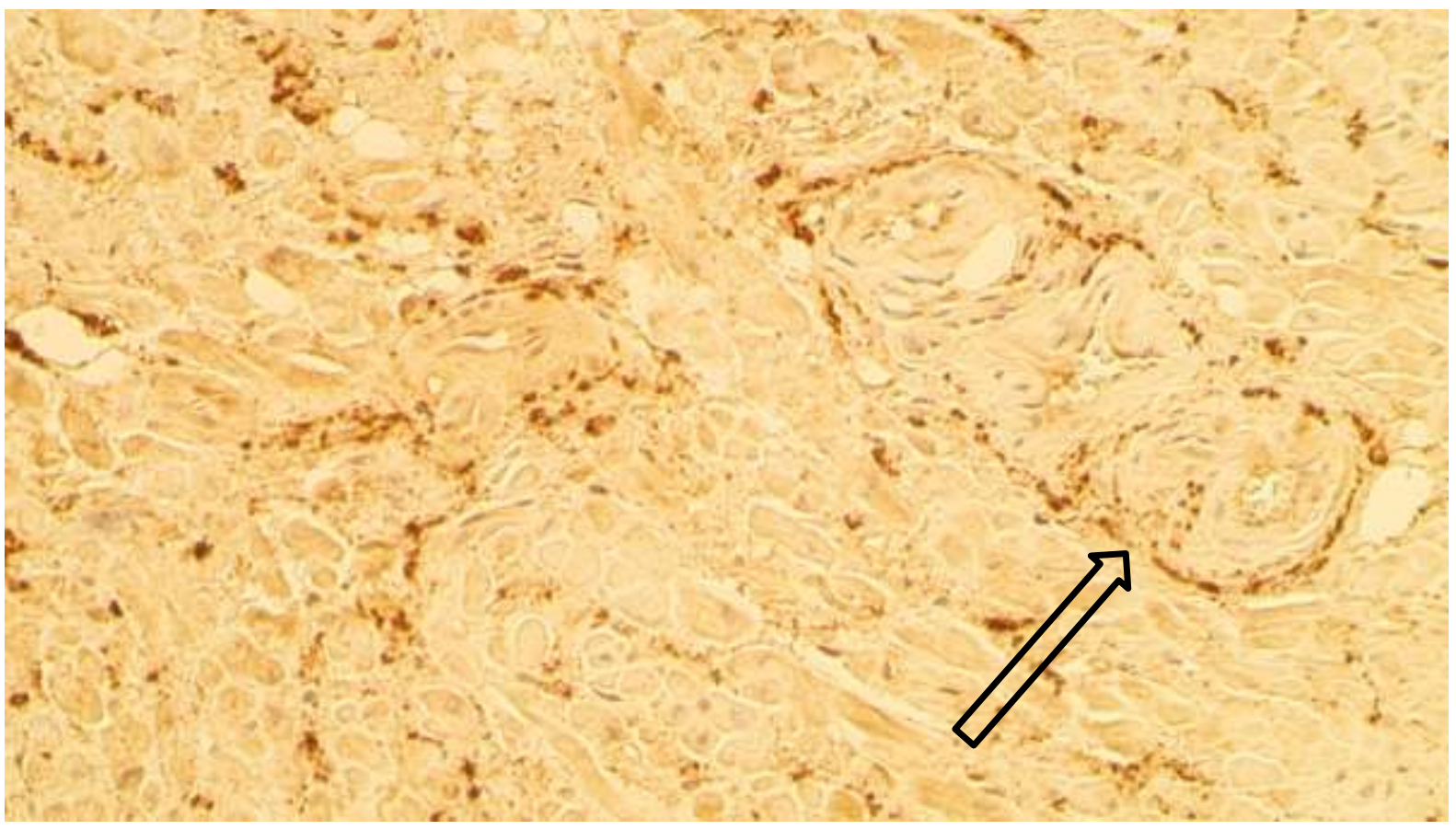

19. attēls. Daudz PGP 9.5 saturošu nervu šḳiedru ap asinsvadiem labā priekškambara audos 64 gadus vecam pacientam ar KSS (bultiņa, PGP 9.5 IMH, ×200)

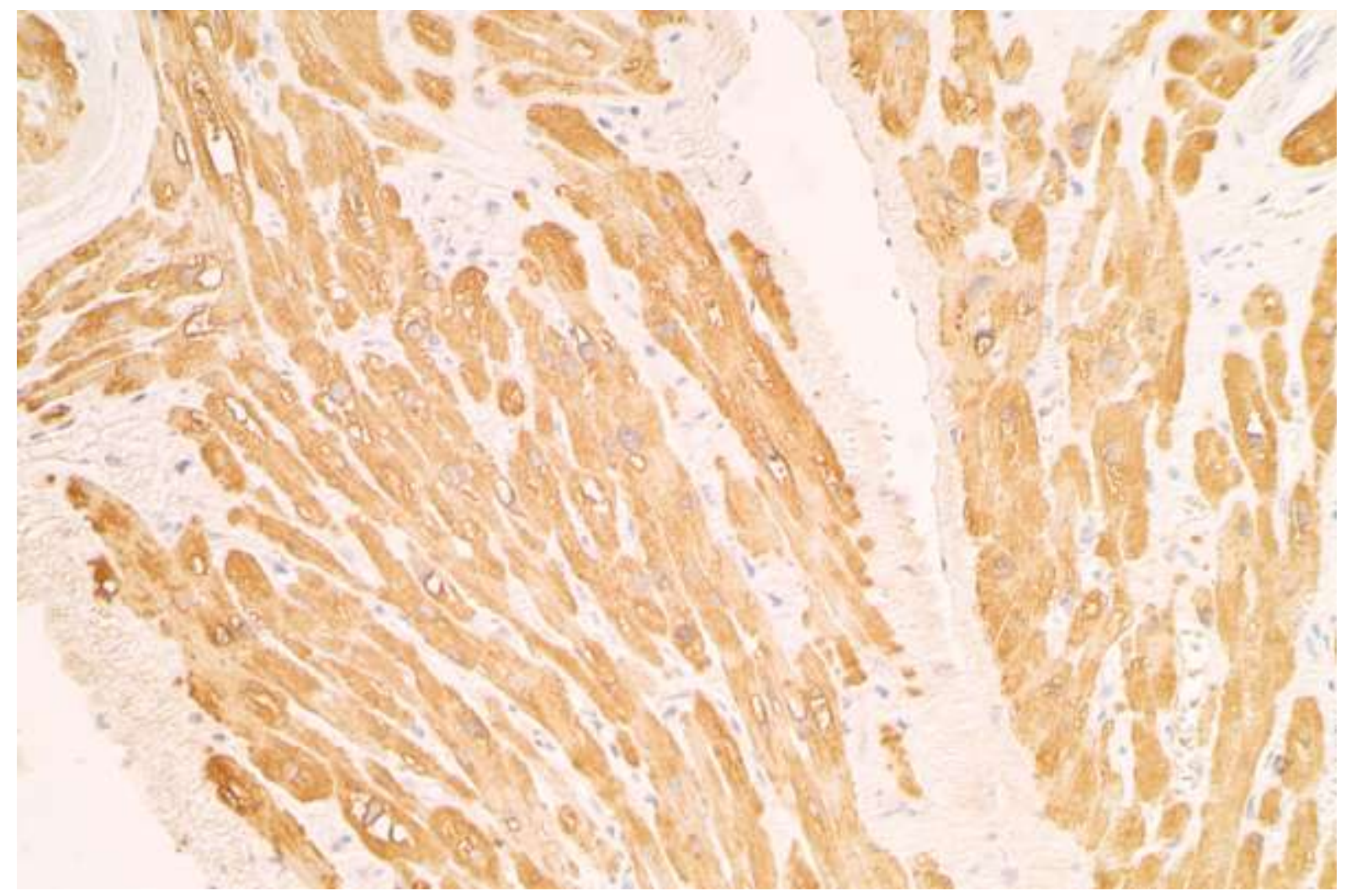

20. attēls. Daudz ANUP pozitīvu kardiomiocītu labā priekškambara audos 56 gadus vecam pacientam ar KSS (ANUP IMH, ×200) 


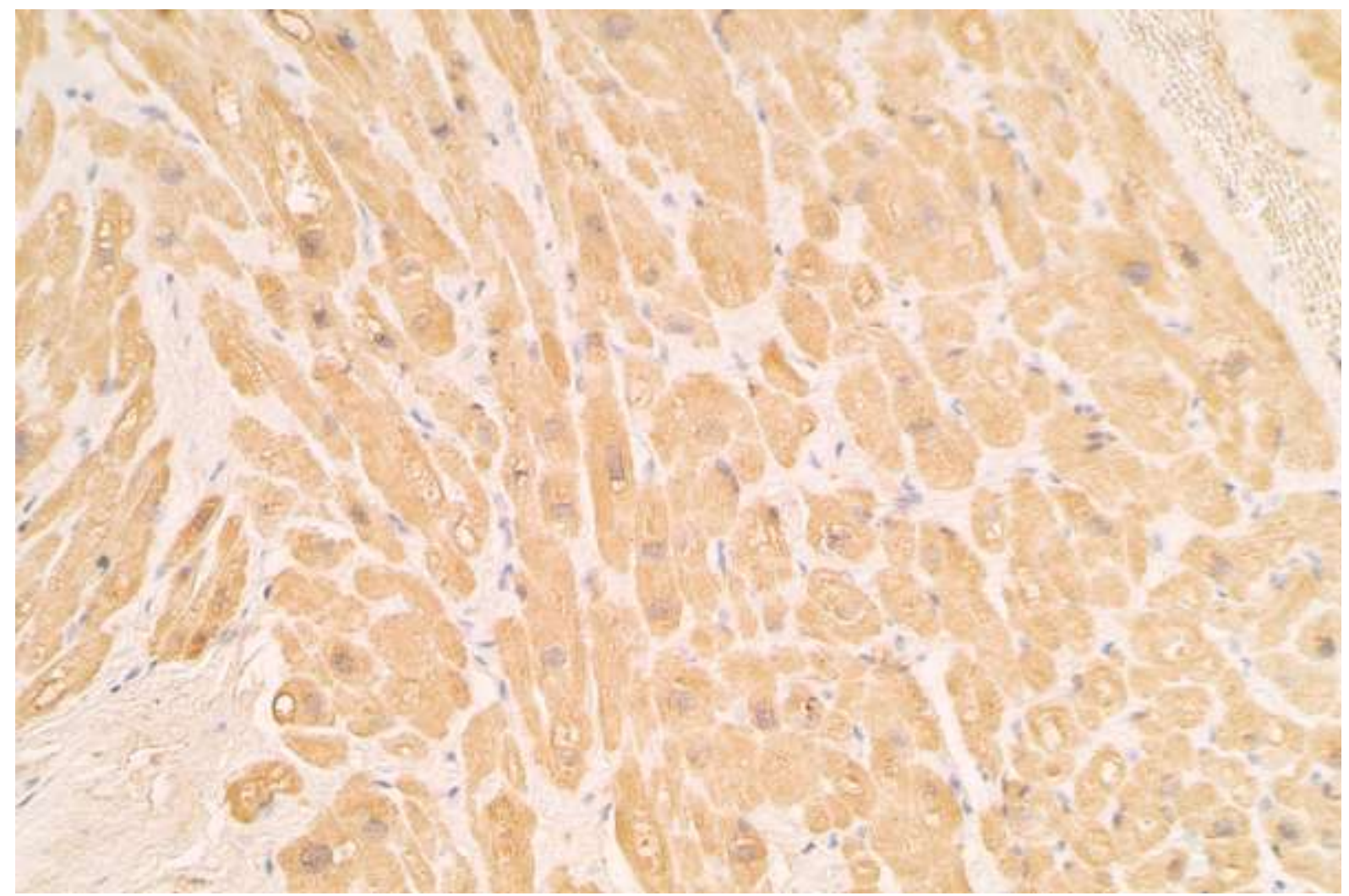

21. attēls. Daudz ANUP pozitīvu kardiomiocītu labā priekškambara audos 52 gadus vecam pacientam ar deǵeneratīvu AoV stenozi (ANUP IMH, ×200)

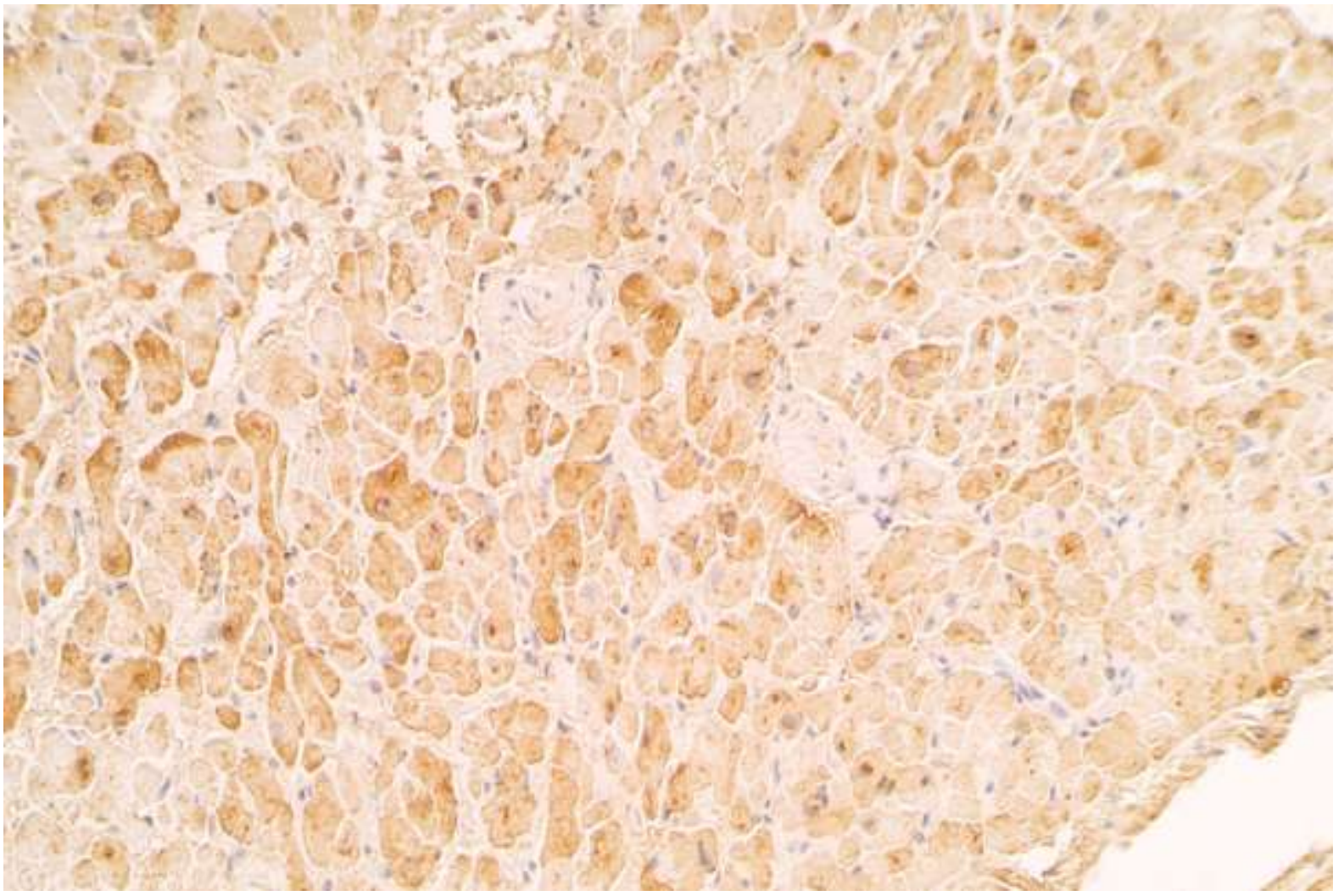

22. attēls. Vidēji daudz ANUP pozitīvu kardiomiocìtu labā priekškambara audos 52 gadus vecam pacientam ar KSS (ANUP IMH, ×200) 


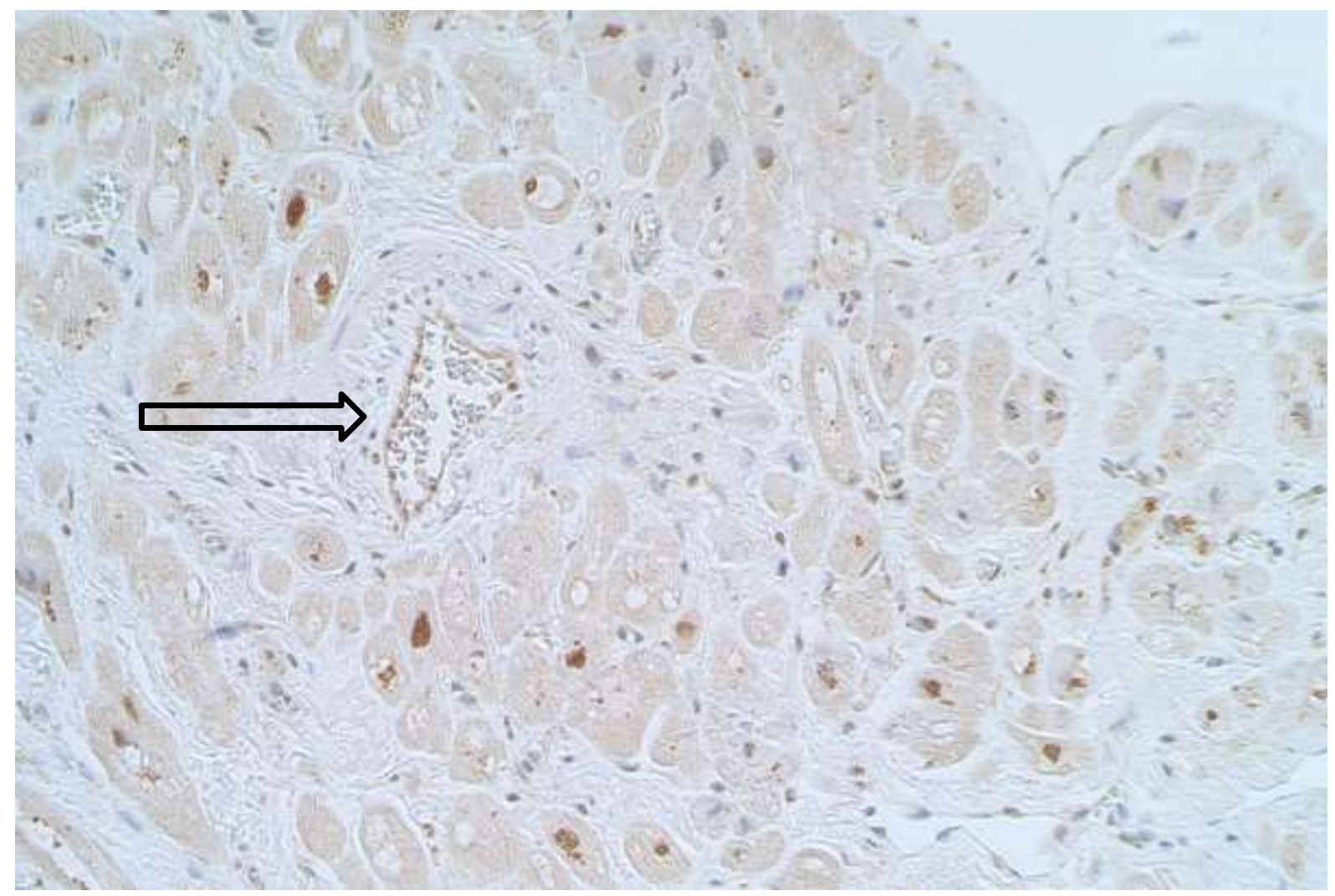

23. attēls. Vidēji daudz VEGF pozitīvu endotēlija šūnu labā priekškambara asinsvadā 78 gadus vecam pacientam ar KSS (bultiņa, VEGF IMH, $\times 200$ )

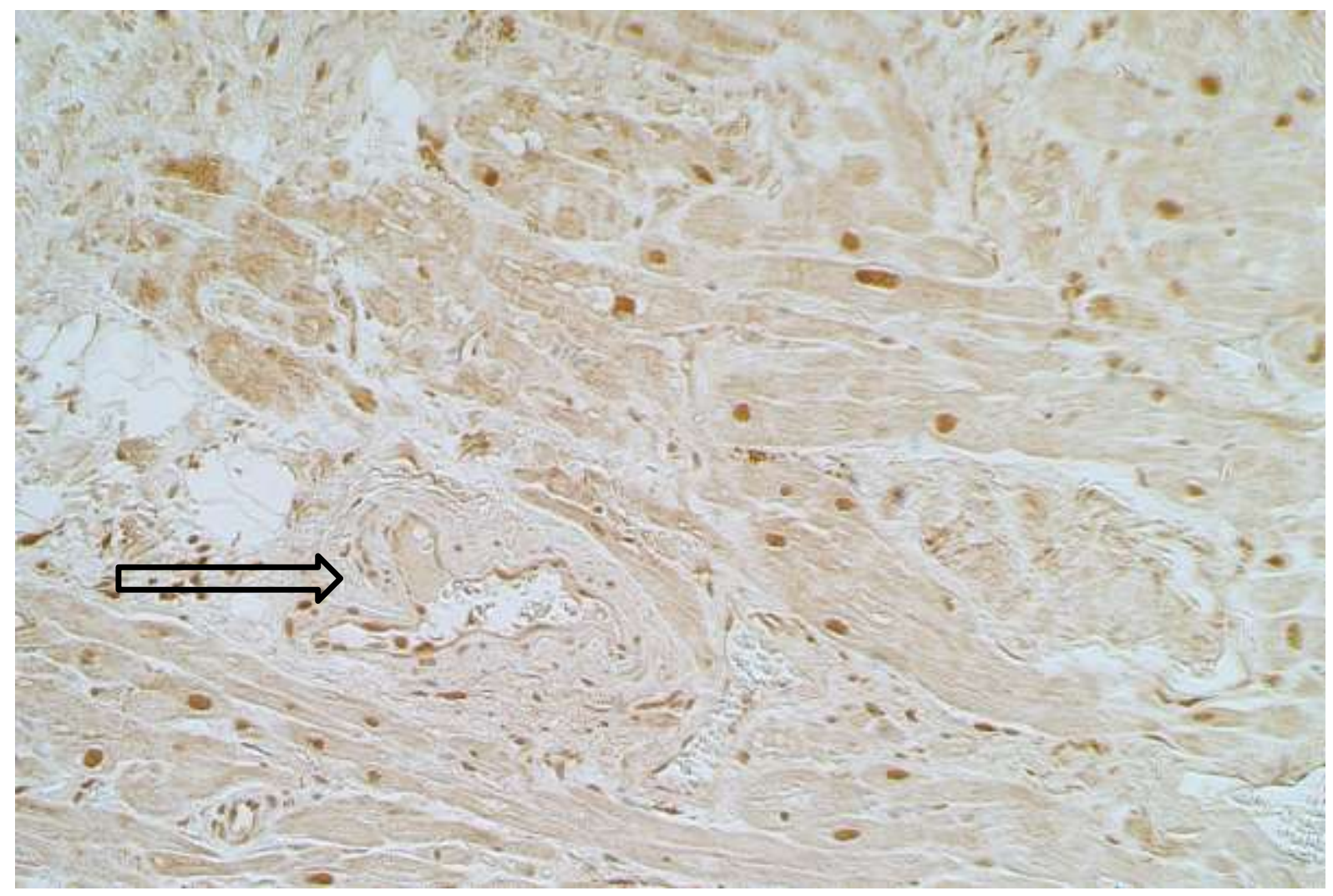

24. attēls. Vidēji daudz VEGF pozitīvu endotēlija šūnu labā priekškambara asinsvadā 53 gadus vecam pacientam ar AoV stenozi (bultina, VEGF IMH, ×200) 


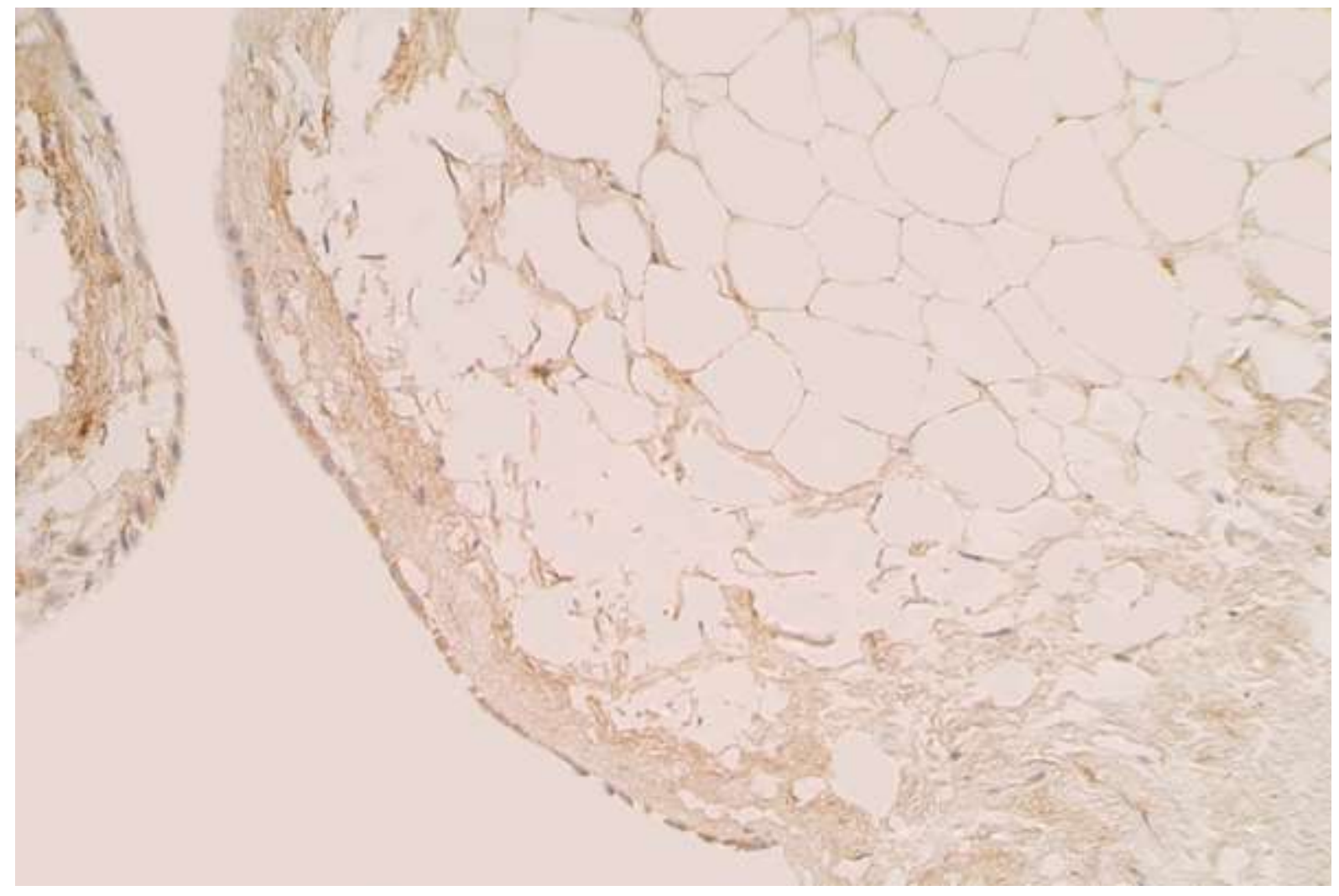

25. attēls. Daudz vāji iekrāsotu VEGF pozitīvu kubiskas formas epikarda epitēlija šūnu labā priekškambara audos 63 gadus vecam pacientam ar KSS (VEGF IMH, ×200)

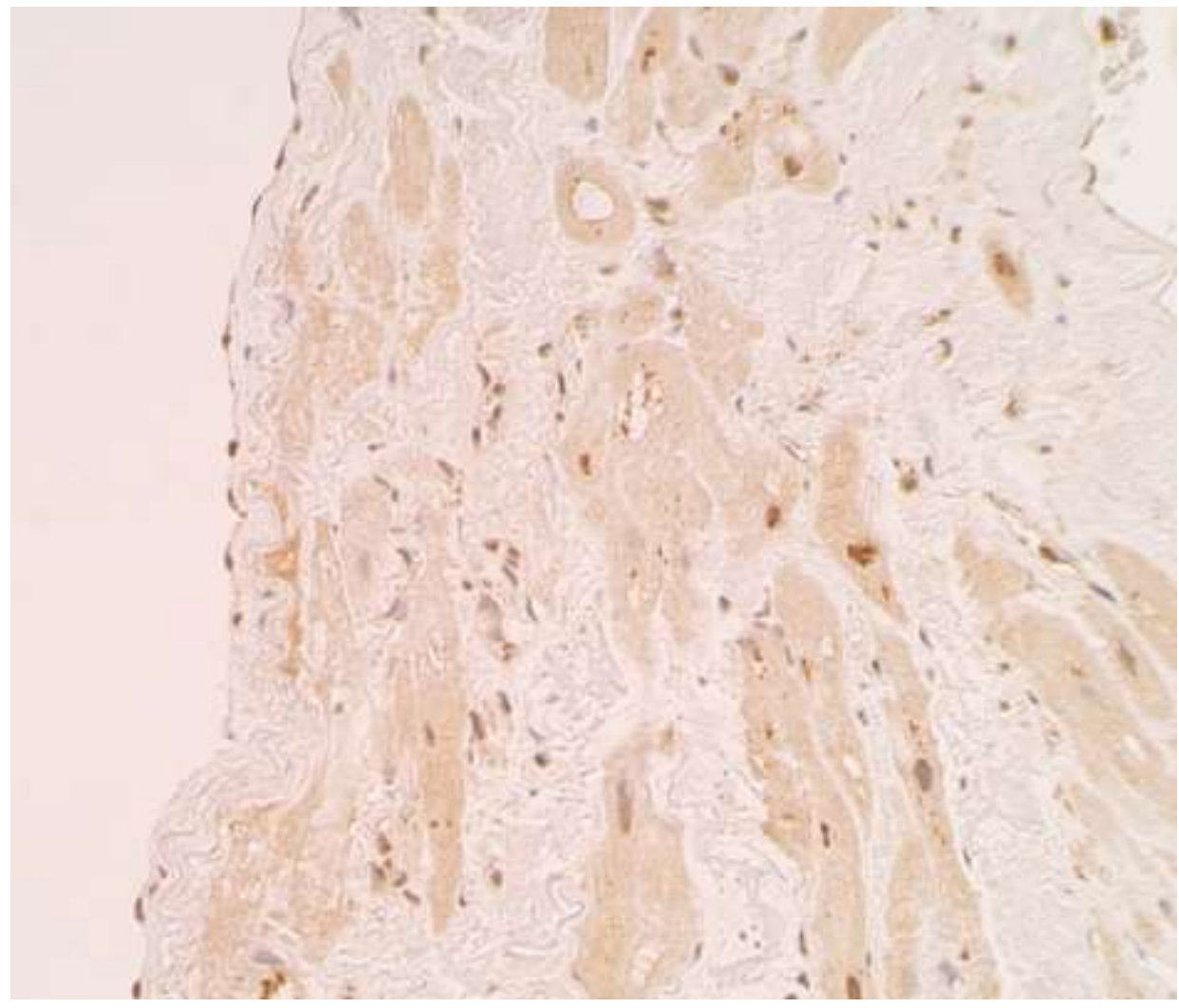

26. attēls. Vidēji daudz VEGF pozitīvu plakanas formas endokarda endotēlija šūnu labā priekškambara audos 78 gadus vecam pacientam ar KSS (VEGF IMH, ×200) 


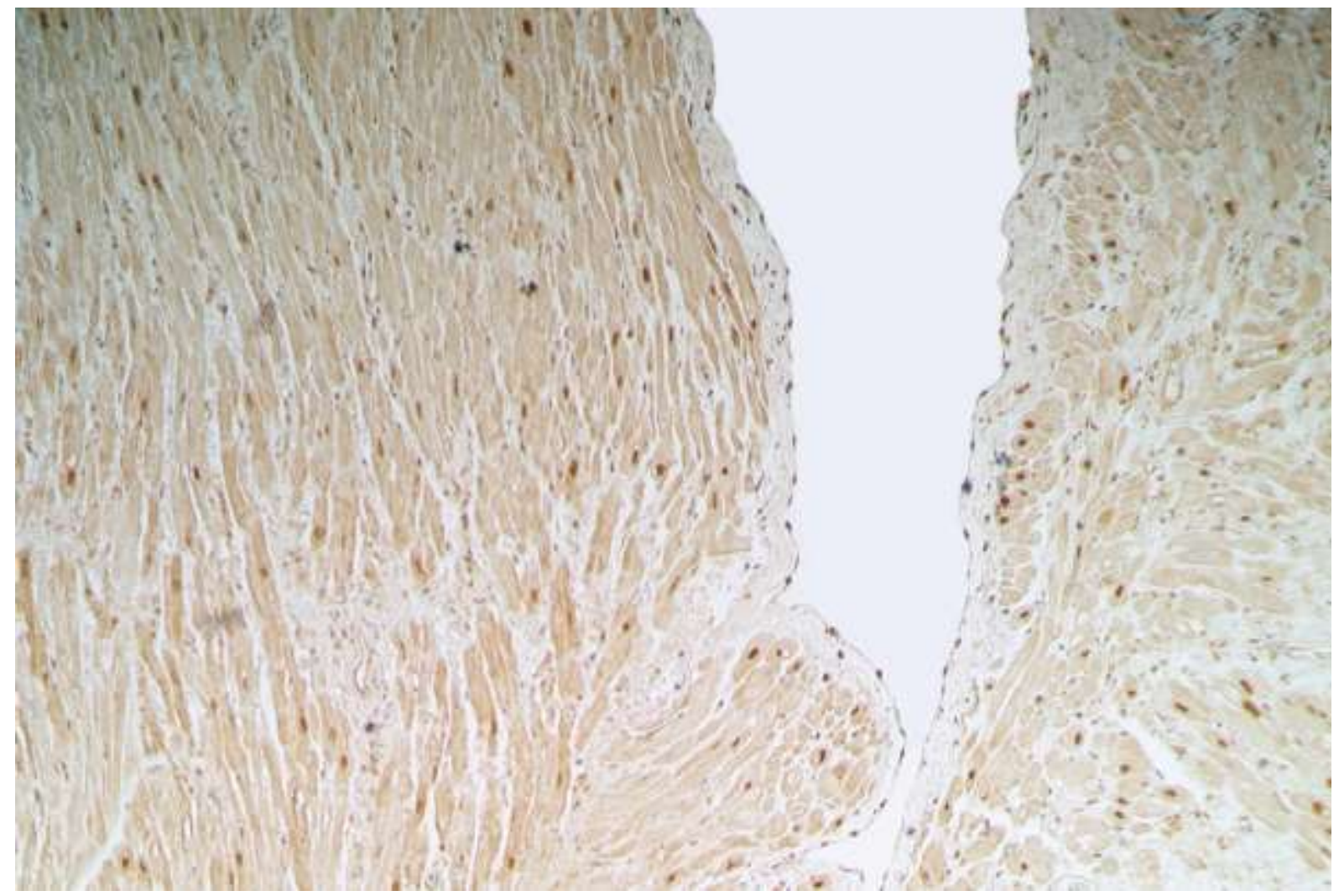

27. attēls. Daudz VEGF pozitīvu plakanas formas endokarda endotēlija šūnu labā priekškambara audos 78 gadus vecam pacientam ar AoV stenozi (VEGF IMH, ×100)

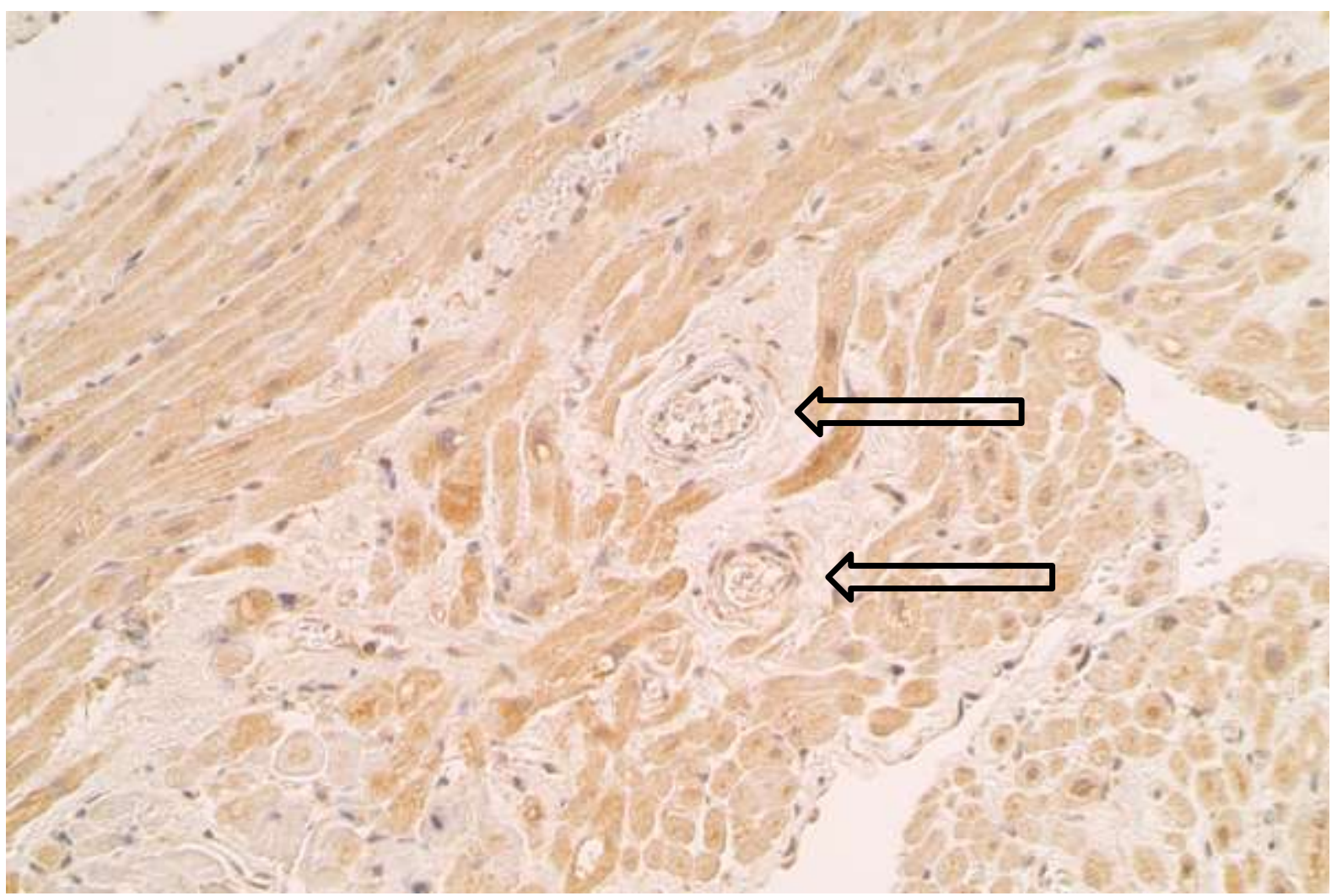

28. attēls. Vidēji daudz ChgA pozitīvu endotēlija šūnu labā priekškambara asinsvados 63 gadus vecam pacientam ar KSS (bultinas, ChgA IMH, ×200) 


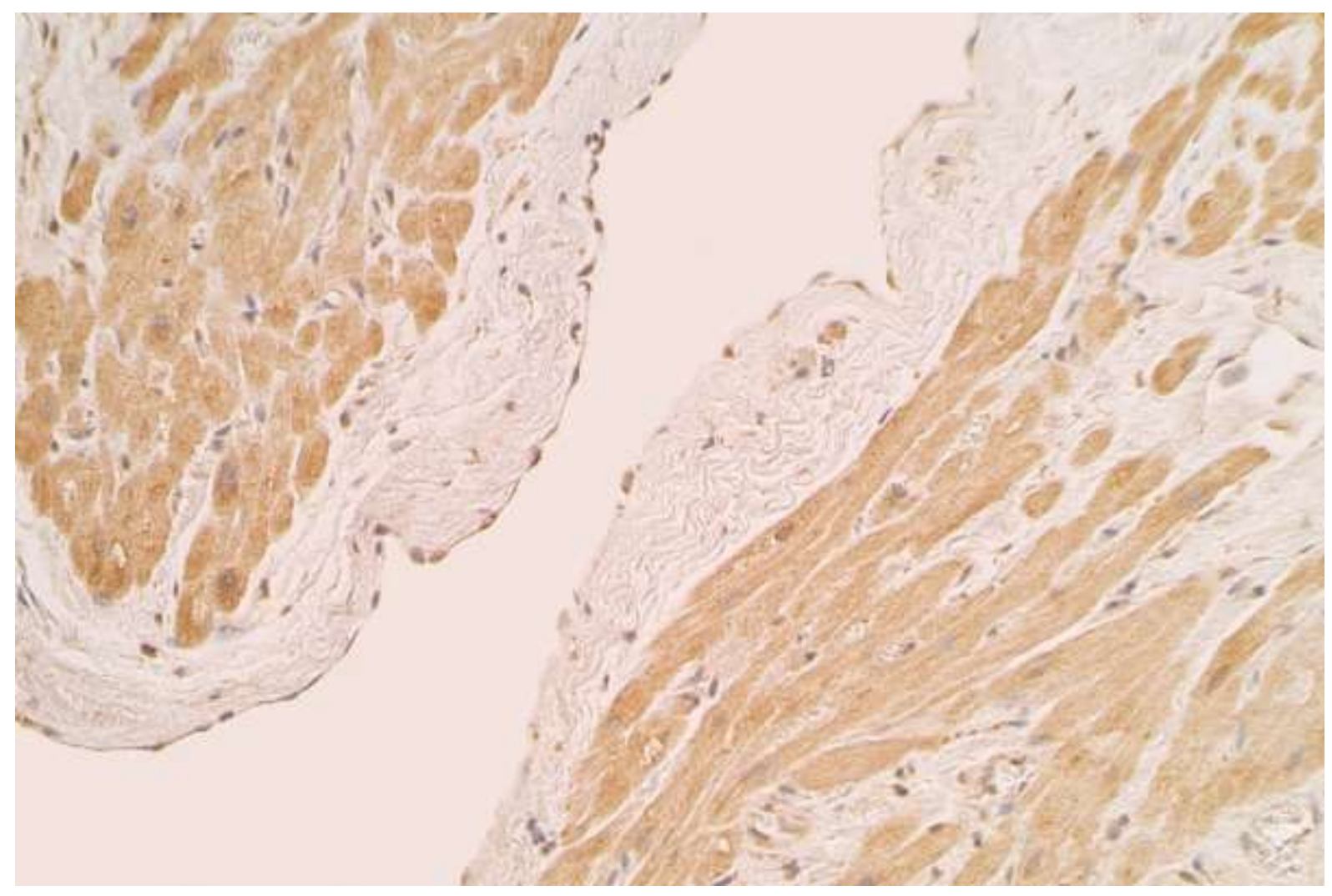

29. attēls. Vidēji daudz ChgA pozitīvu plakanas formas endokarda endotēlija šūnu labā priekškambara audos 63 gadus vecam pacientam ar KSS (ChgA IMH, ×200)

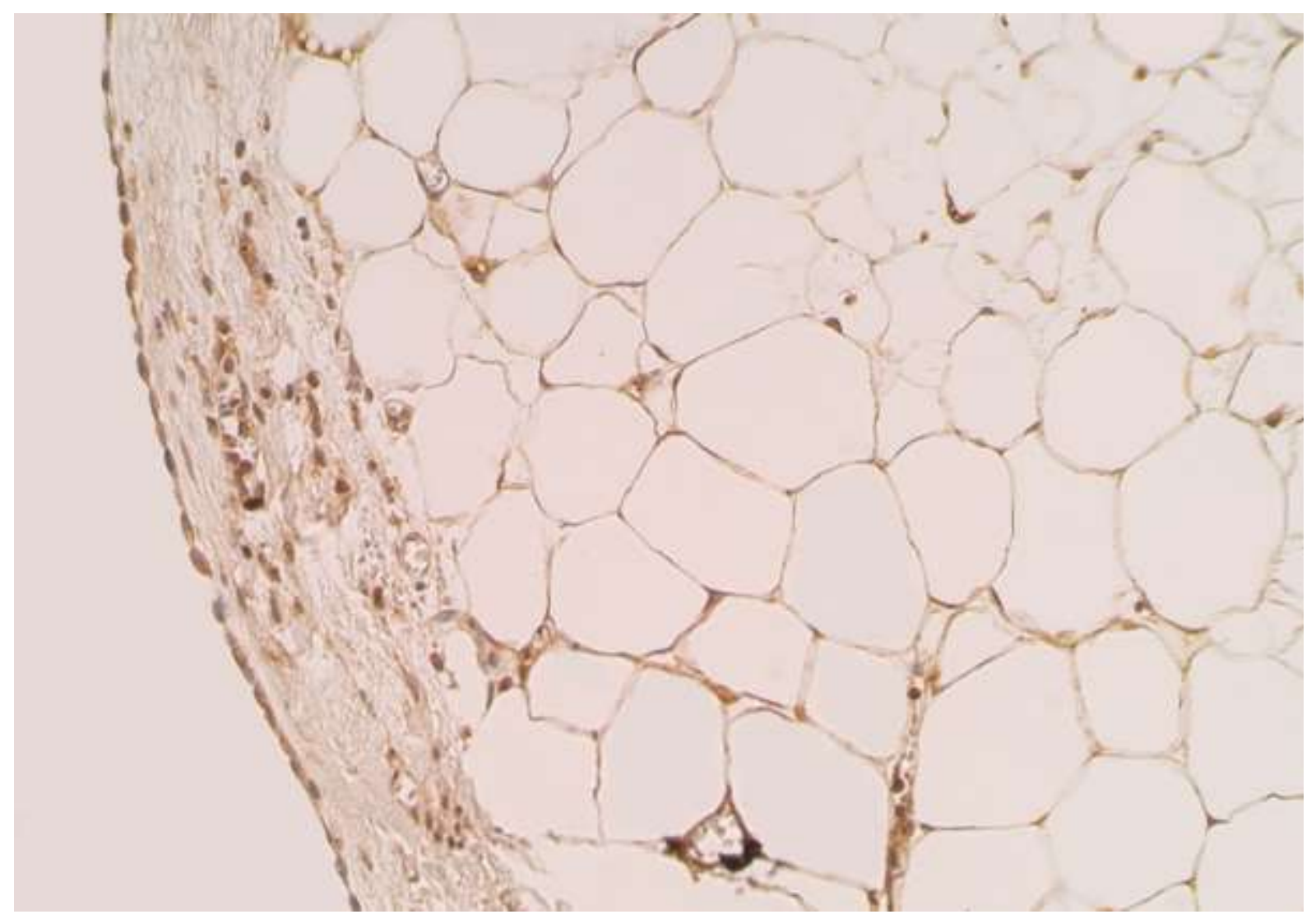

30. attēls. Daudz ChgA pozitīvu epikarda epitēlija šūnu labā priekškambara audos 63 gadus vecam pacientam ar KSS $(\mathrm{ChgA} \mathrm{IMH,} \times 200)$ 


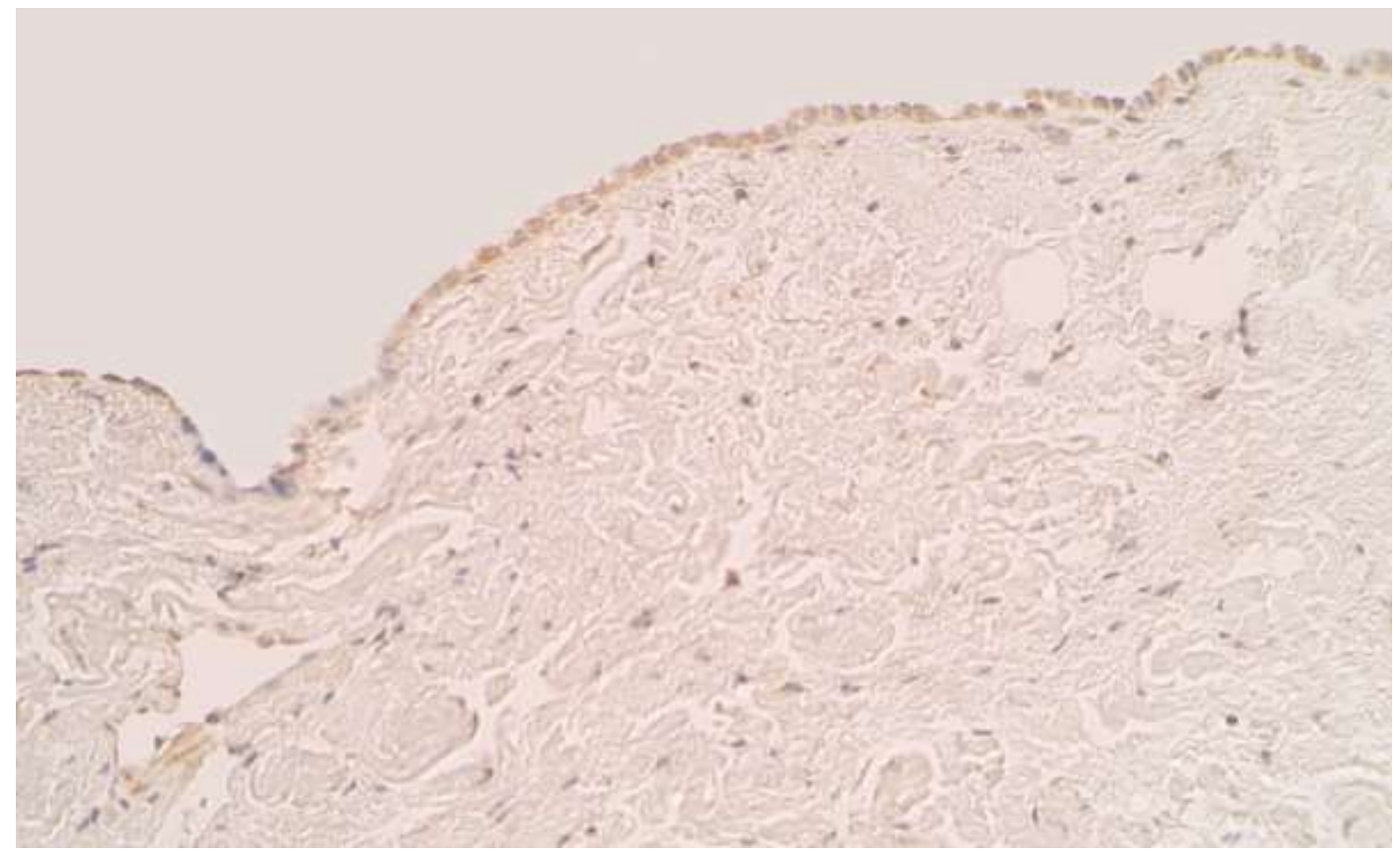

31. attēls. Daudz ChgA pozitīvu kubiskas formas epikarda epitēlija šūnu labā priekškambara audos 69 gadus vecam pacientam ar deǵenerativu AoV stenozi (ChgA IMH, ×200)

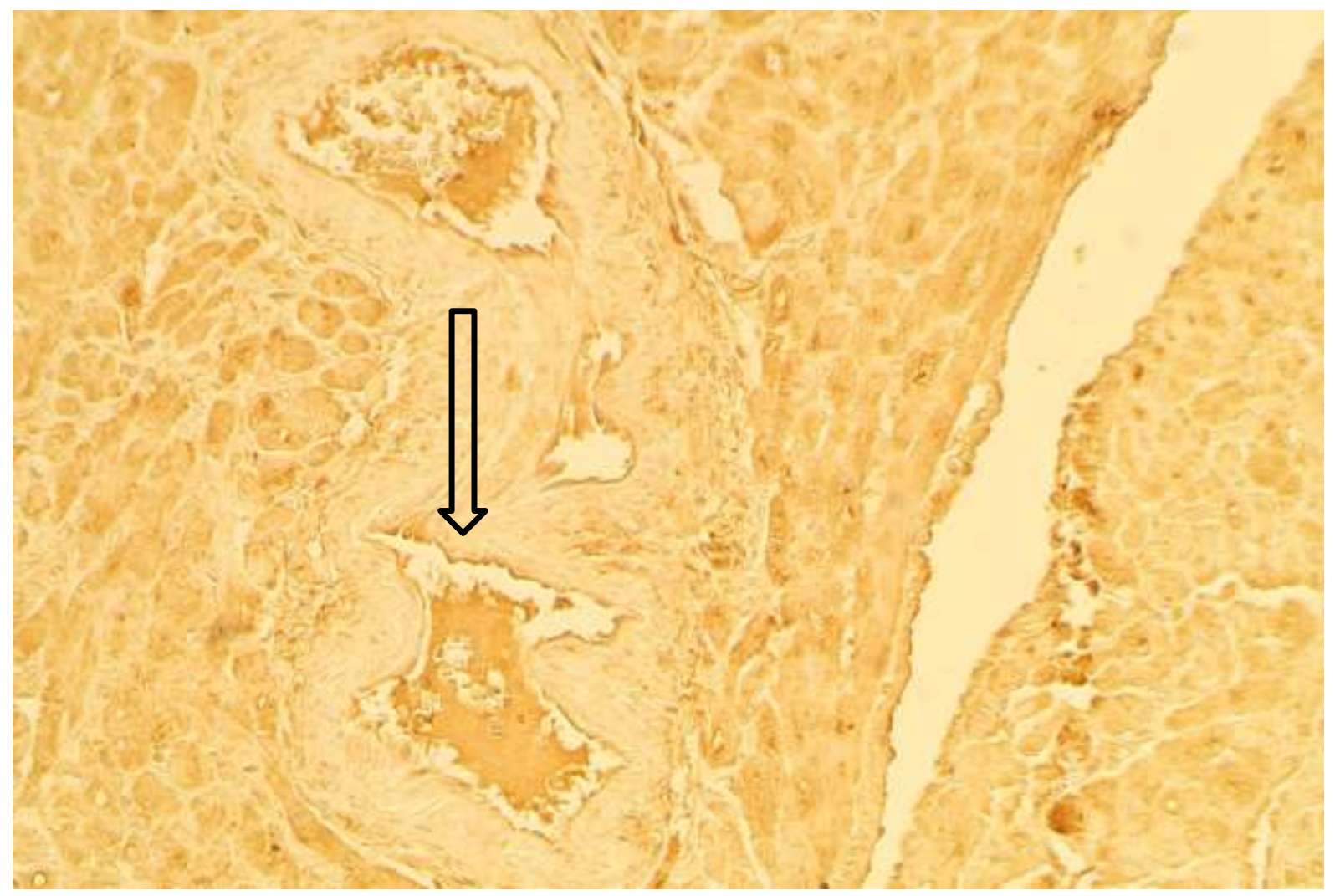

32. attēls. Vidēji daudz ET-1 pozitīvu endotēlija šūnu labā priekškambara asinsvados 66 gadus vecam pacientam ar KSS (bultiņa, ET-1 IMH, ×200) 


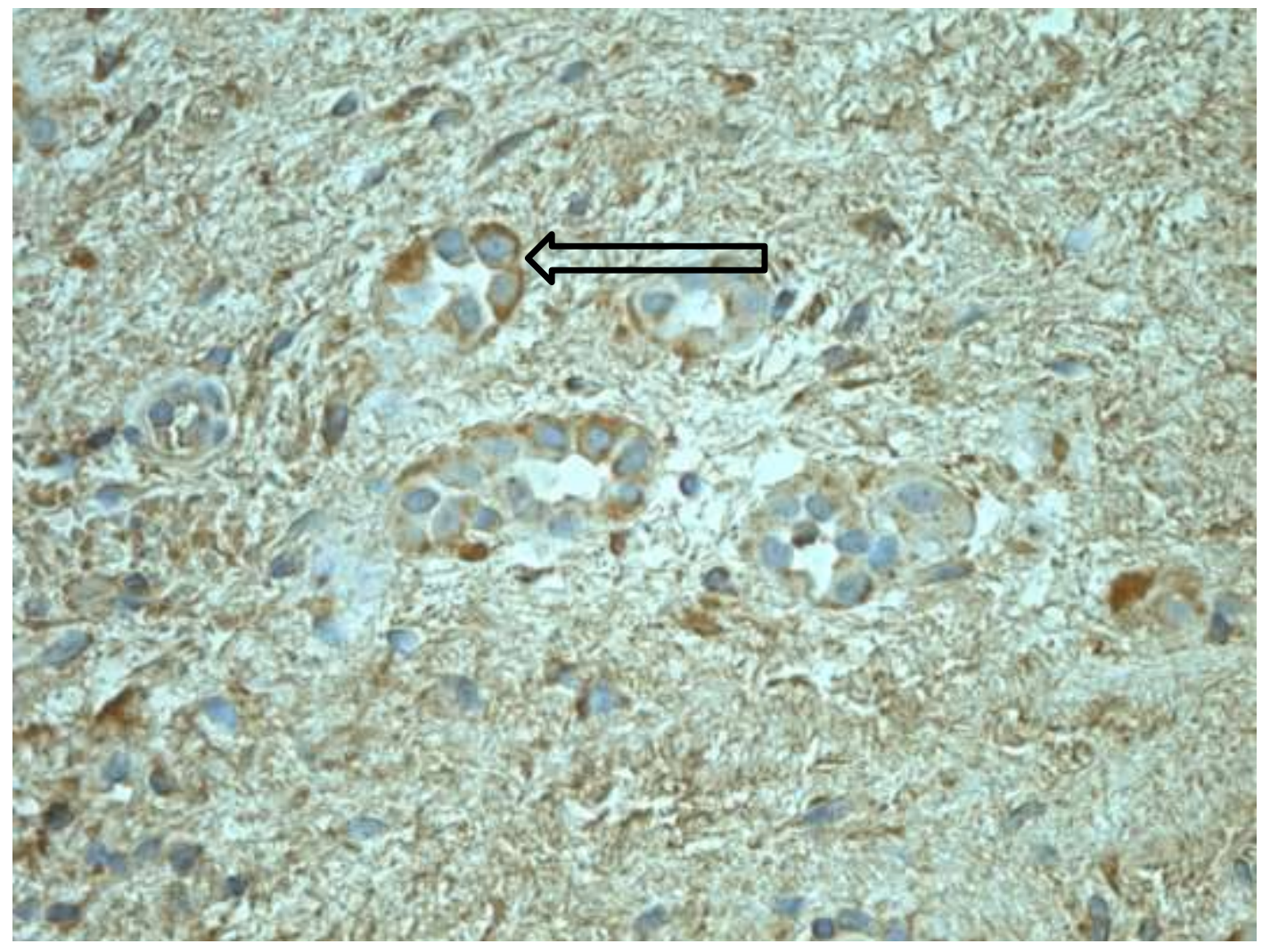

33. attēls. Vidēji daudz ET-1 pozitīvu endotēlija šūnu labā priekškambara asinsvados 70 gadu vecam pacientam ar deǵeneratīvu AoV stenozi (bultiṇa, ET-1 IMH, ×400)

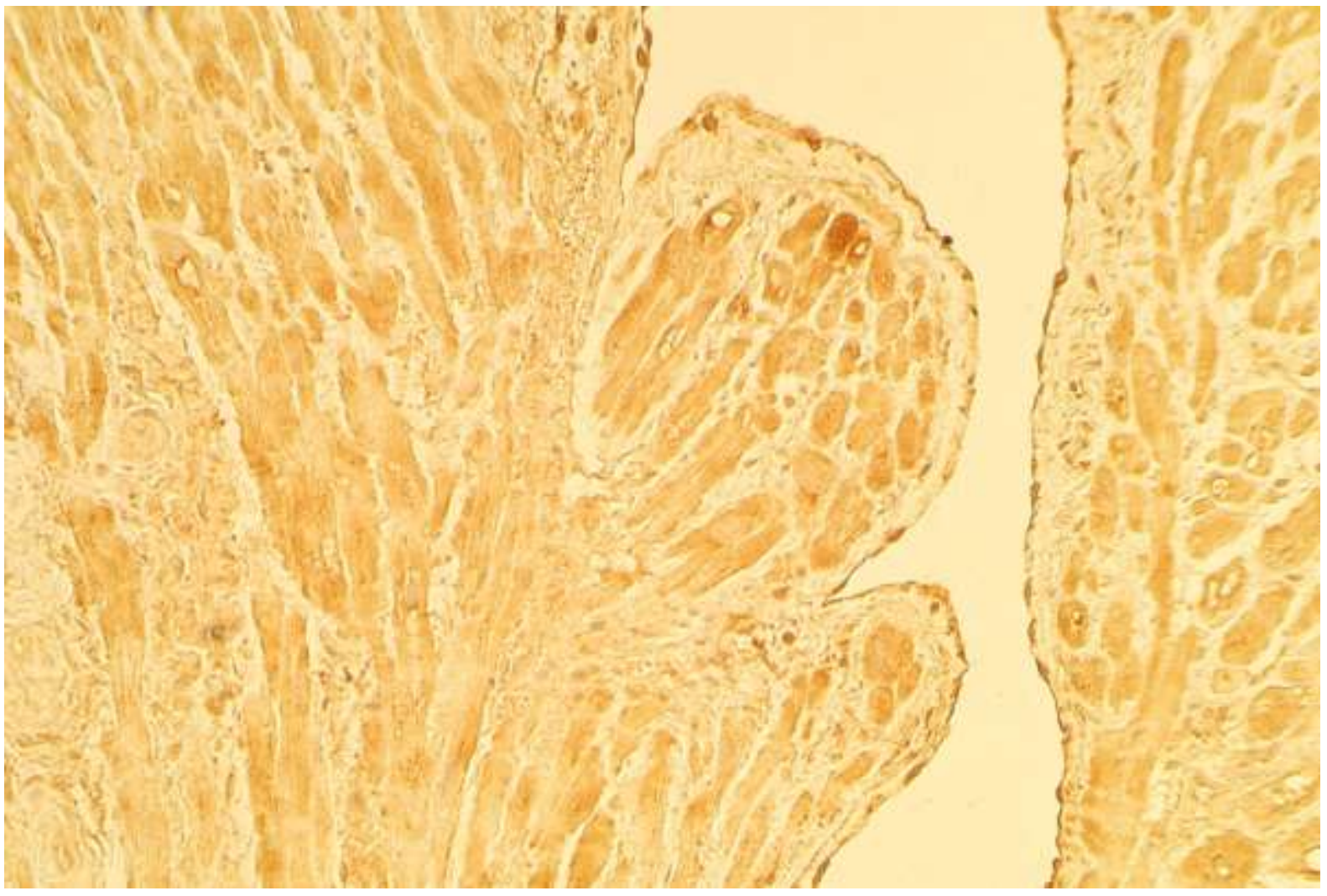

34. attēls. Daudz ET-1 pozitīvu plakanas formas endokarda endotēlija šūnu labā priekškambara audos 78 gadus vecam pacientam ar deǵeneratīvu AoV stenozi $($ ET-1 IMH, ×200) 


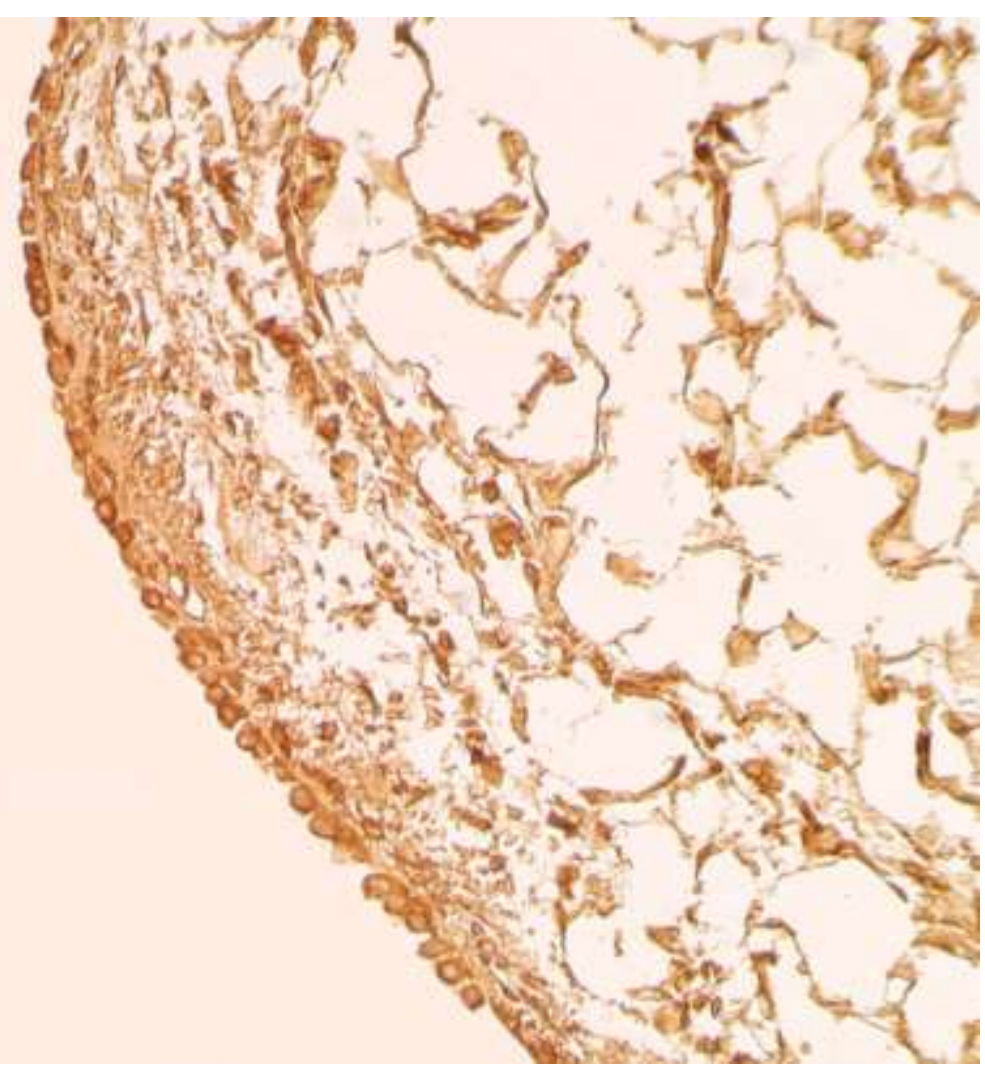

35. attēls. Ļoti daudz ET-1 pozitīvu kubiskas formas endokarda endotēlija šūnu labā priekškambara audos 58 gadus vecam pacientam ar deǵeneratīvu AoV stenozi

(ET- 1 IMH, ×200)

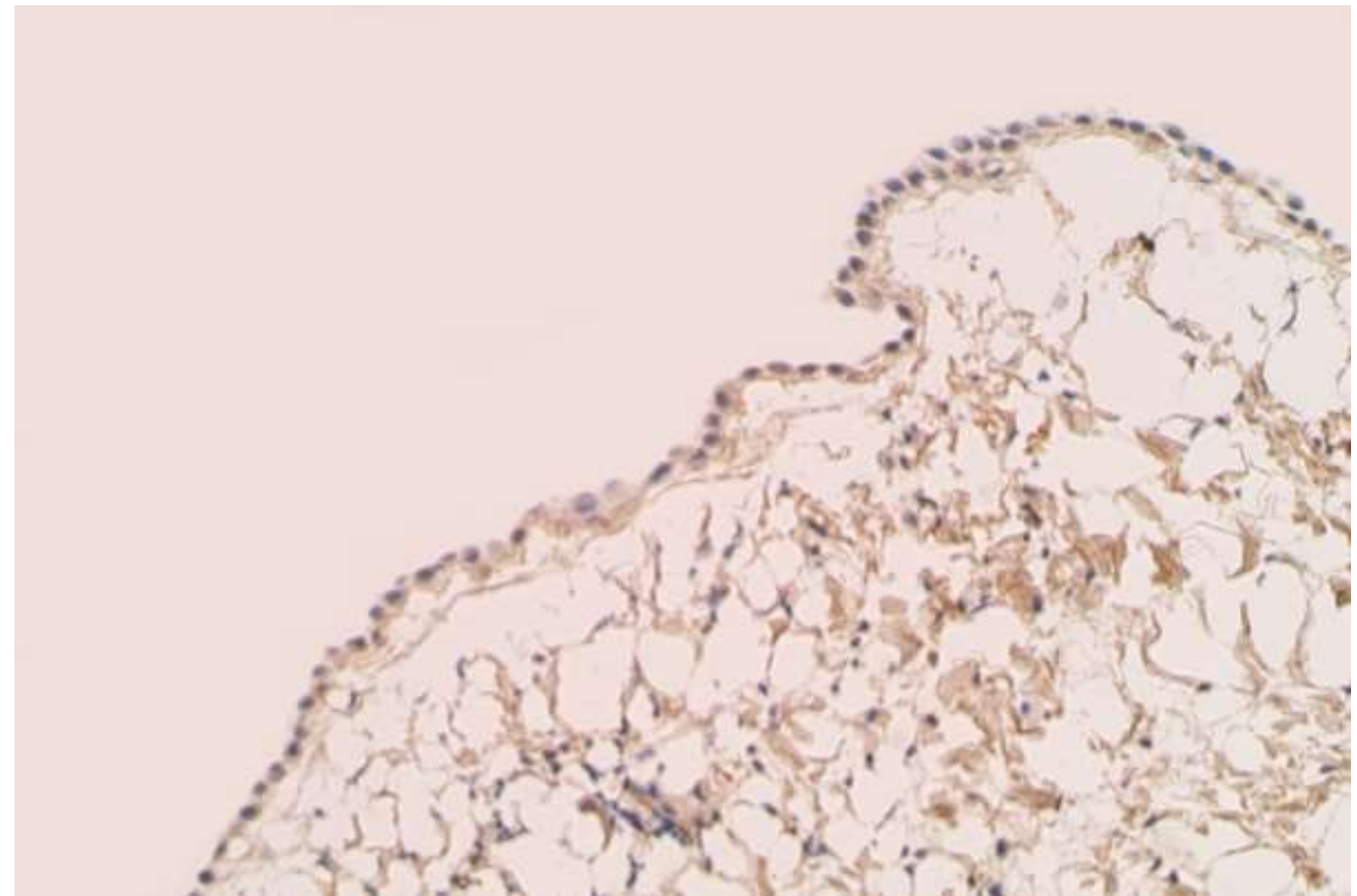

36. attēls. Retas Il-1 $\alpha$ pozitīvas kubiskas formas epikarda epitēlija šūnas labā priekškambara audos 58 gadus vecam pacientam ar deǵeneratīvu AoV stenozi (Il-1 $\alpha$ IMH, × 200) 


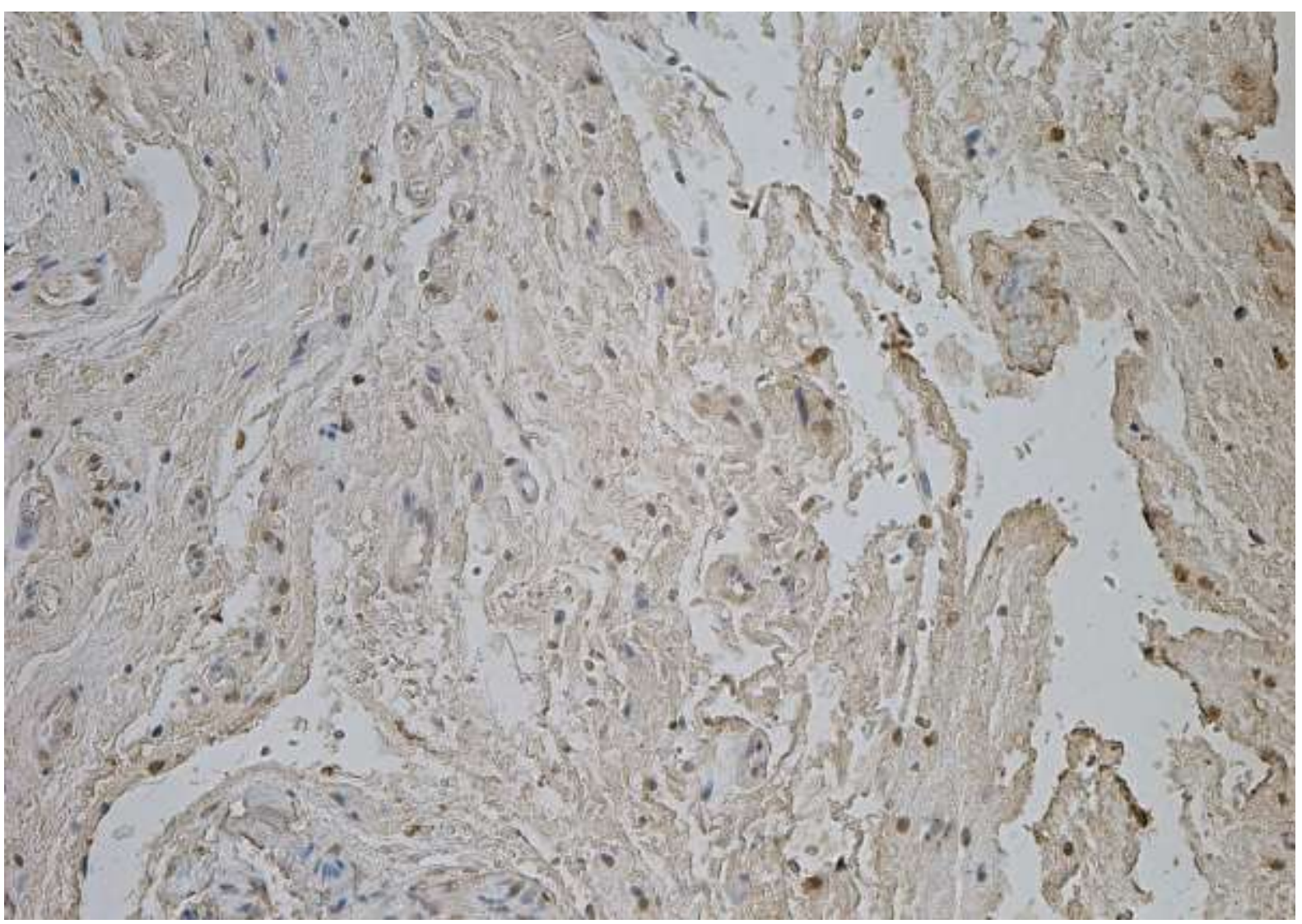

37. attēls. Maz līdz vidēji daudz Il-1 $\alpha$ pozitīvu saistaudu šūnu labā priekškambara audos 80 gadu vecam pacientam ar KSS (Il-1 $\alpha$ IMH, $\times 200)$

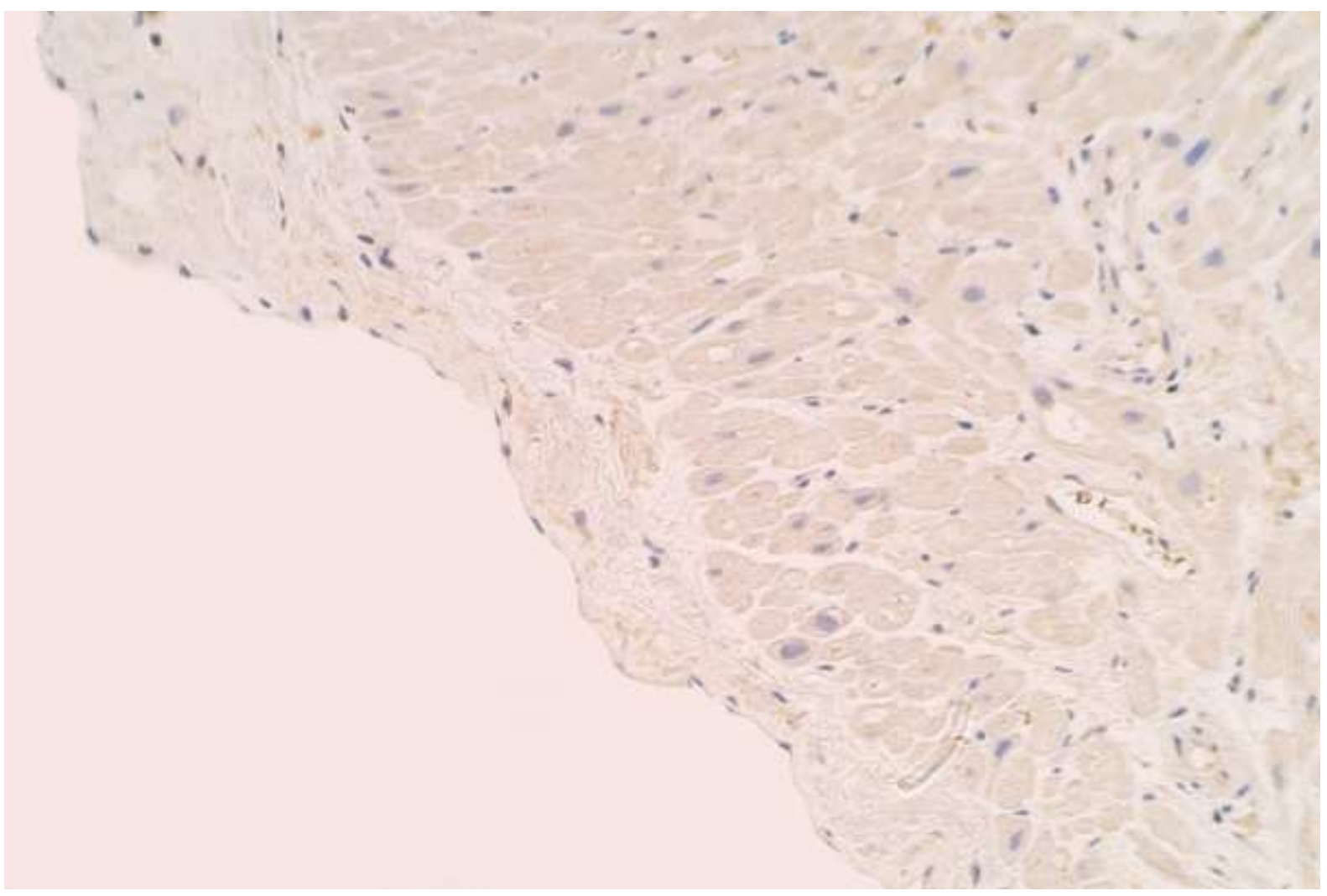

38. attēls. Il-1 $\alpha$ pozitīvu šūnu trūkums labā priekškambara audos $\mathbf{7 8}$ gadus vecam pacientam ar deǵeneratīvu AoV stenozi (II-1 $\alpha$ IMH, ×200) 


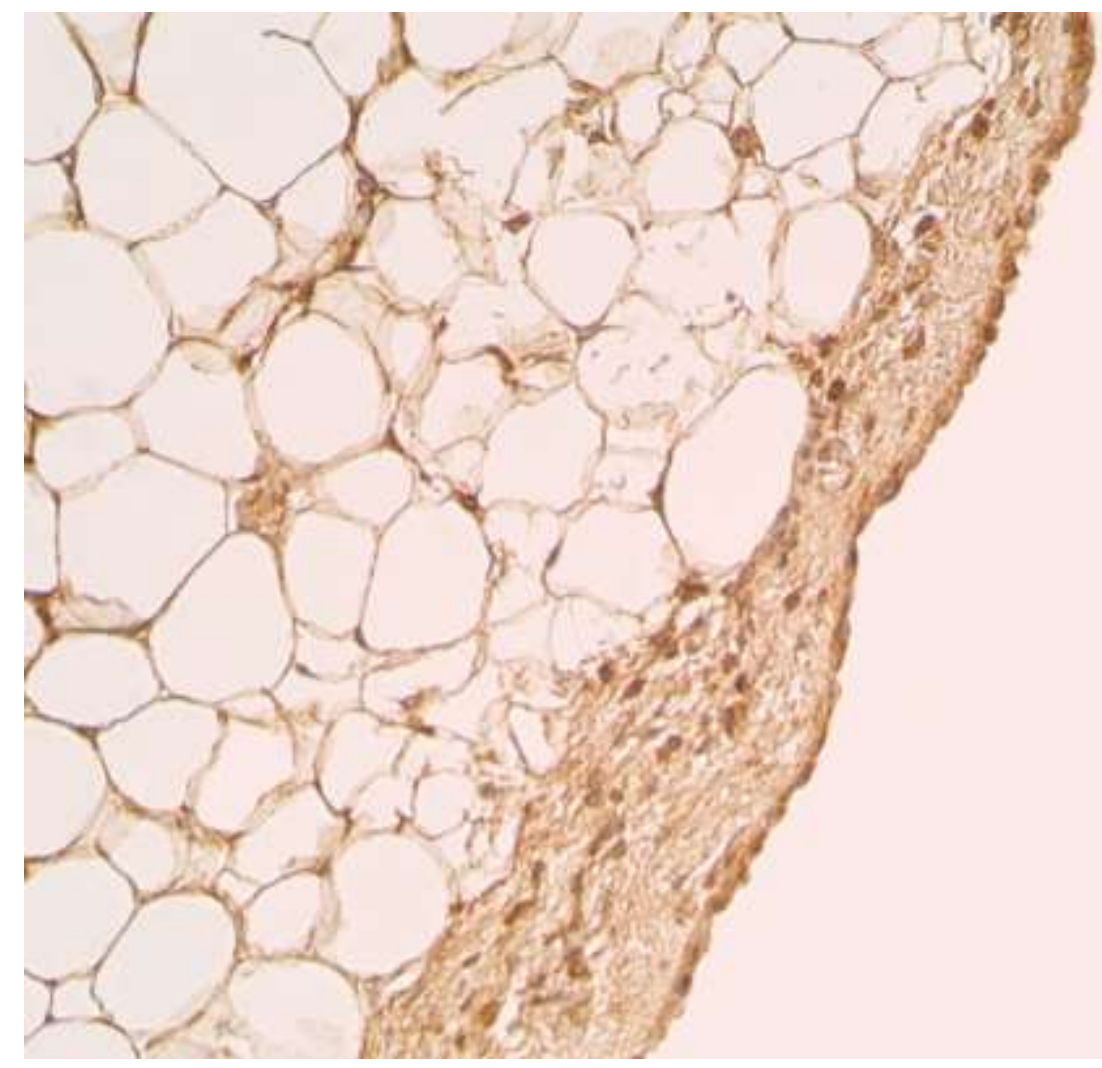

39. attēls. Daudz Il-10 pozitīvu kubiskas formas epikarda epitēlija šūnu labā priekškambara audos 63 gadus vecam pacientam ar KSS $($ Il-10 IMH, $\times 200)$

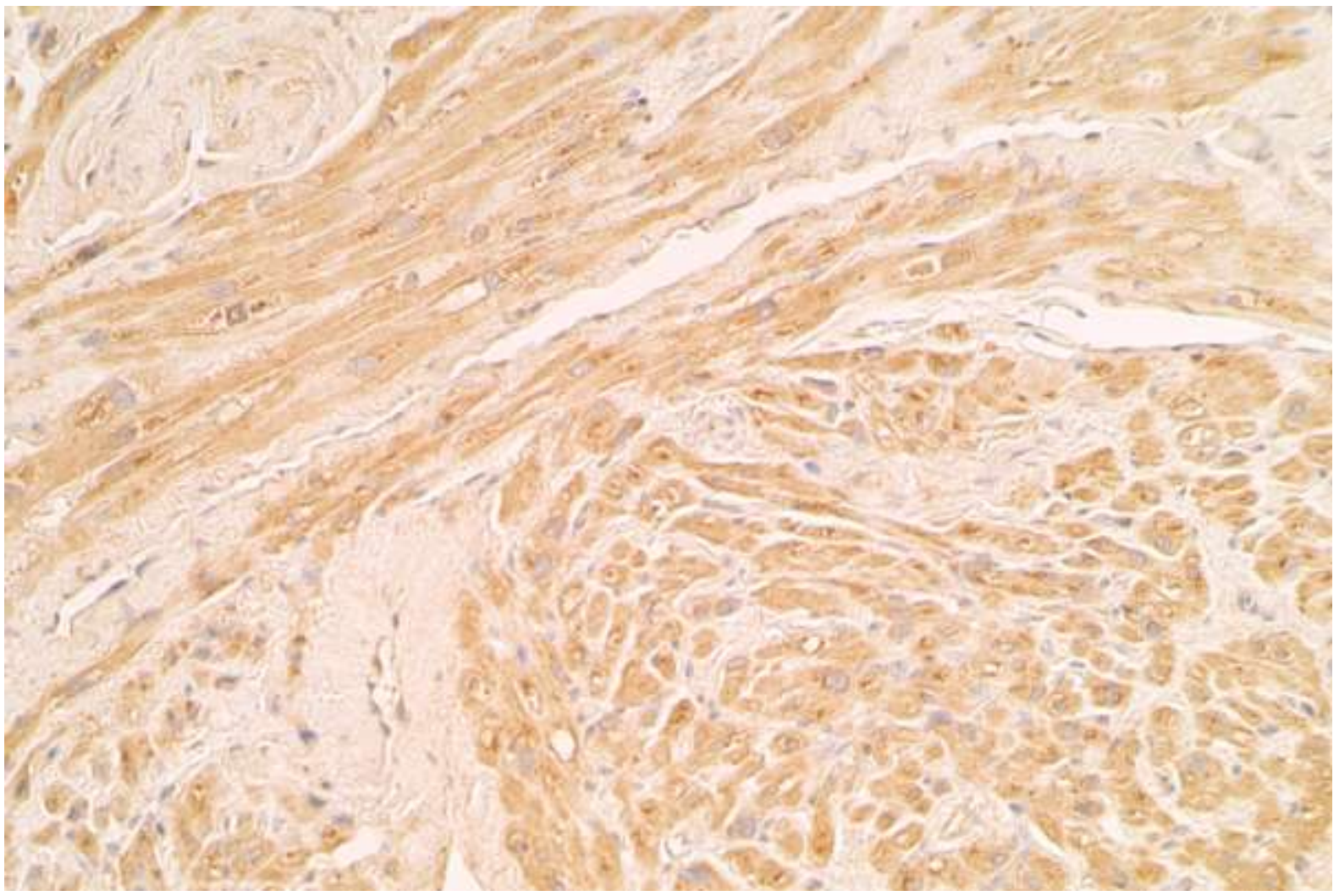

40. attēls. Daudz Il-10 pozitīvu kardiomiocītu labā priekškambara audos 63 gadus vecam pacientam ar KSS (Il-10 IMH, ×200) 


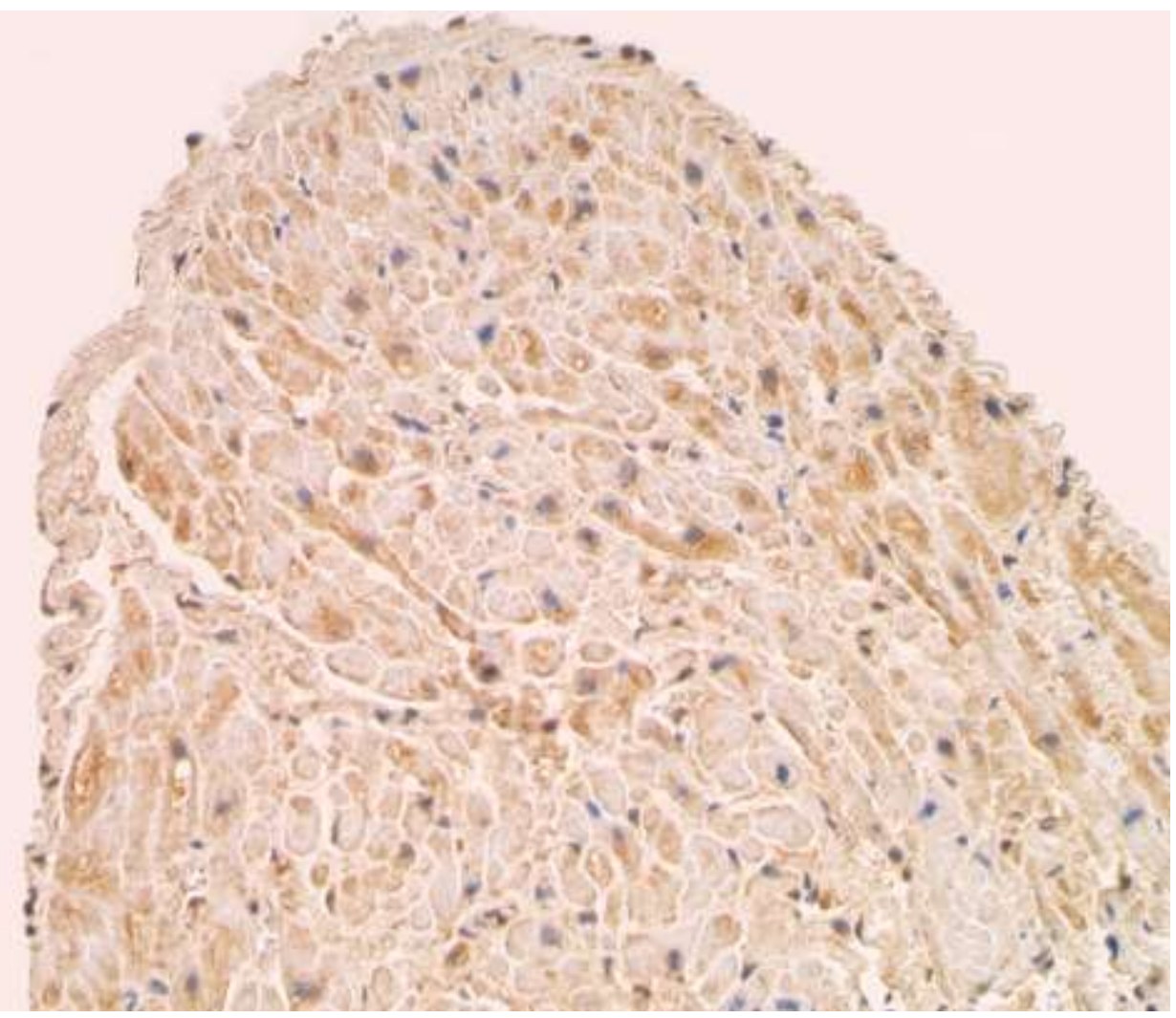

41. attēls. Vidēji daudz Il-10 pozitīvu kardiomiocìtu labā priekškambara audos 67 gadus vecam pacientam ar KSS (Il-10 IMH, ×200)

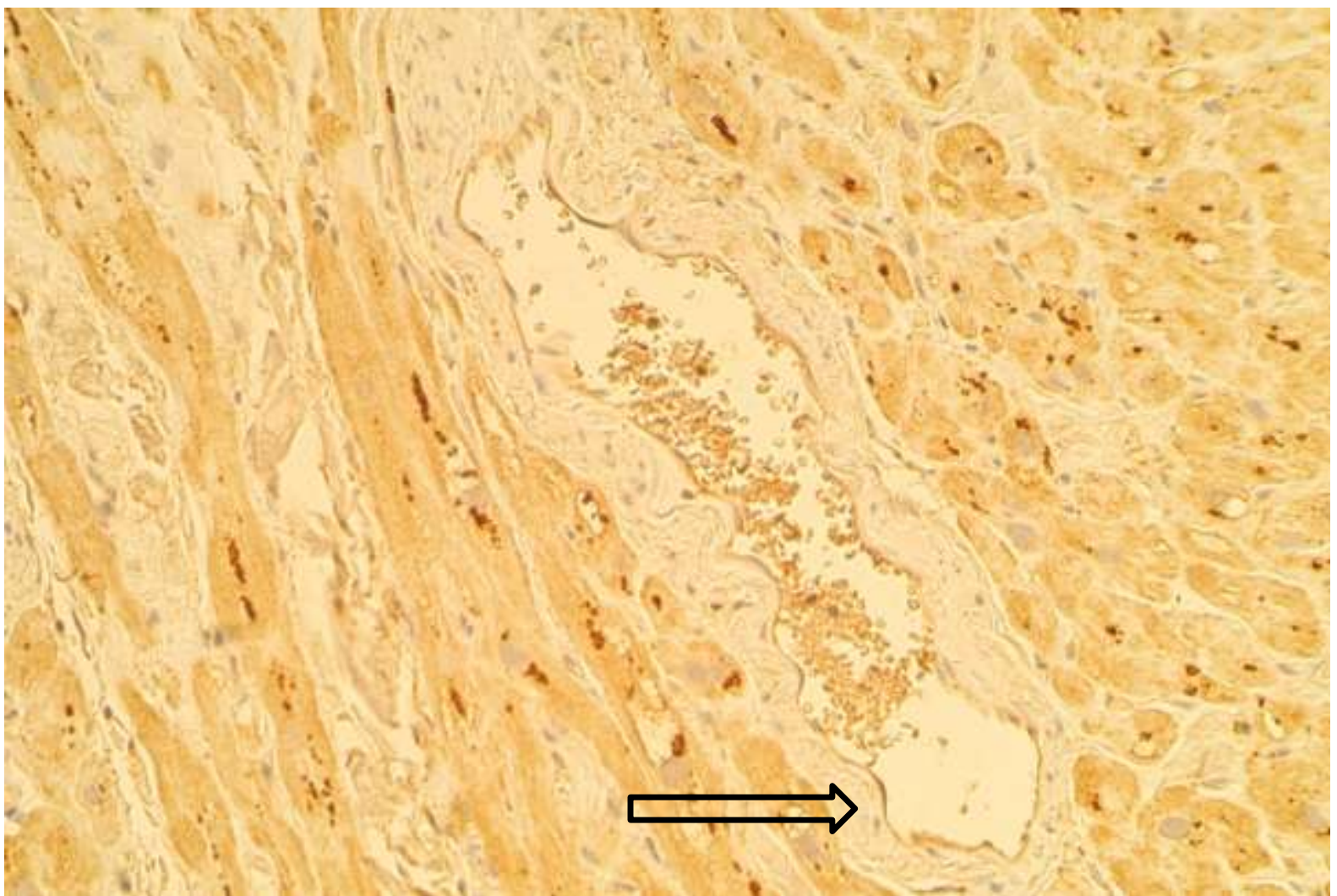

42. attēls. Vidēji daudz Il-10 pozitīvu endotēlija šūnu labā priekškambara asinsvadā 78 gadus vecam pacientam ar KSS (bultina, Il-10 IMH, × 200 ) 


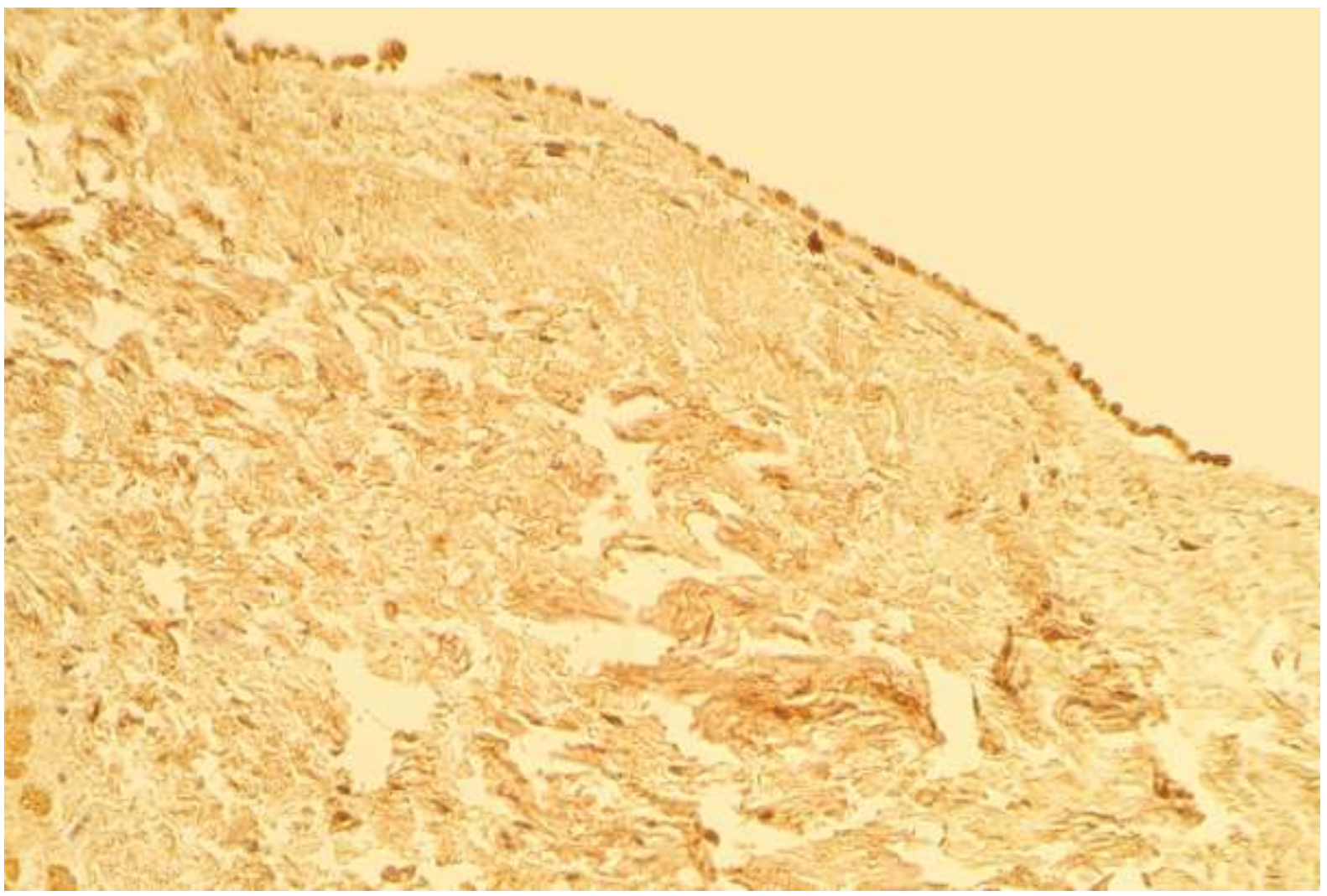

43. attēls. Daudz Il-10 pozitīvu kubiskas formas endokarda endotēlija šūnu labā priekškambara audos 57 gadus vecam pacientam ar KSS (Il-10 IMH, ×200)

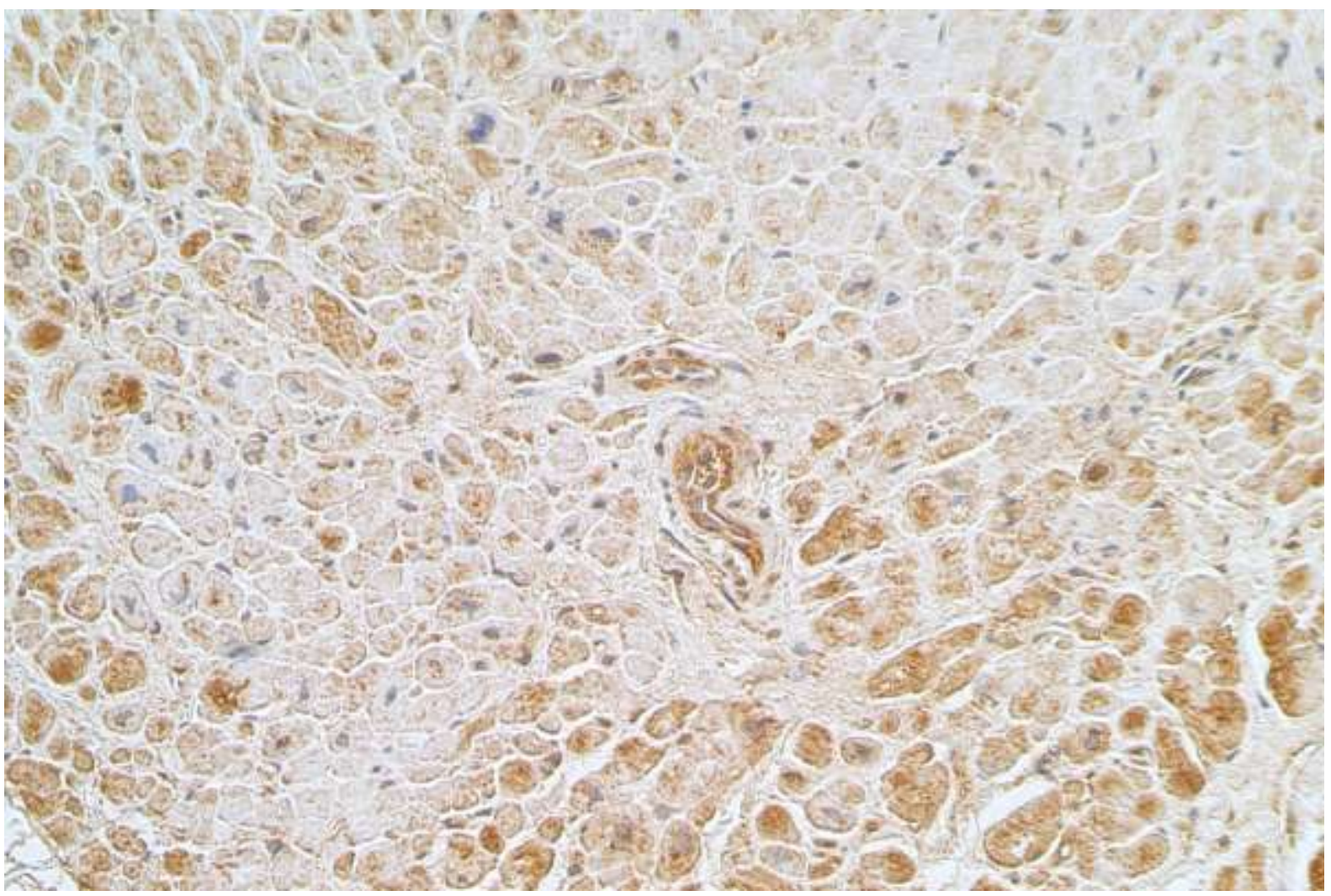

44. attēls. Vidēji daudz Il-10 pozitīvu kardiomiocītu labā priekškambara audos 67 gadus vecam pacientam ar AoV stenozi (Il-10 IMH, ×200) 


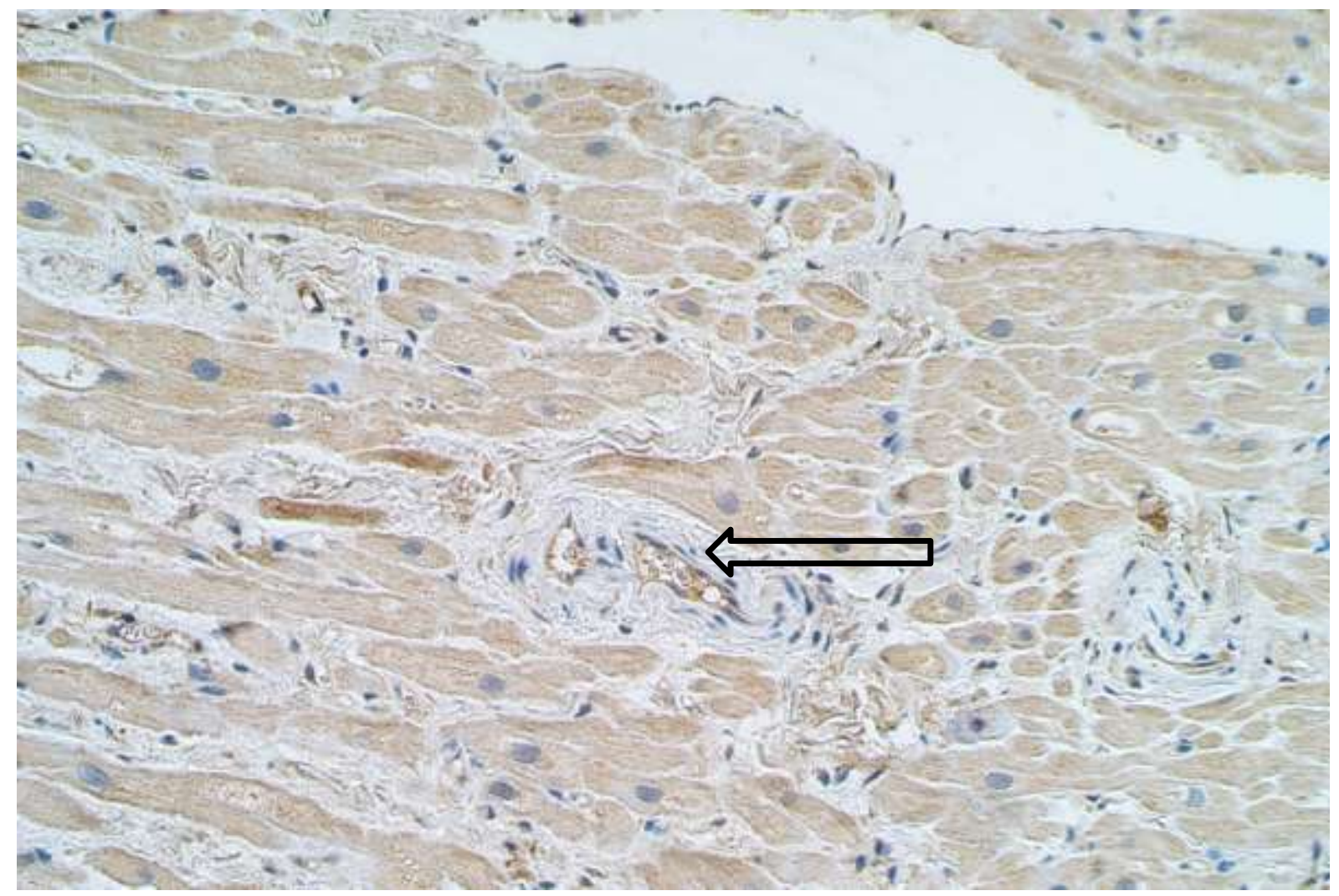

45. attēls. Vidēji daudz vāji iekrāsotu Il-10 pozitīvu endotēlija šūnu labā priekškambara asinsvadā 53 gadus vecam pacientam ar AoV stenozi (bultiņa, Il-10 IMH, ×200)

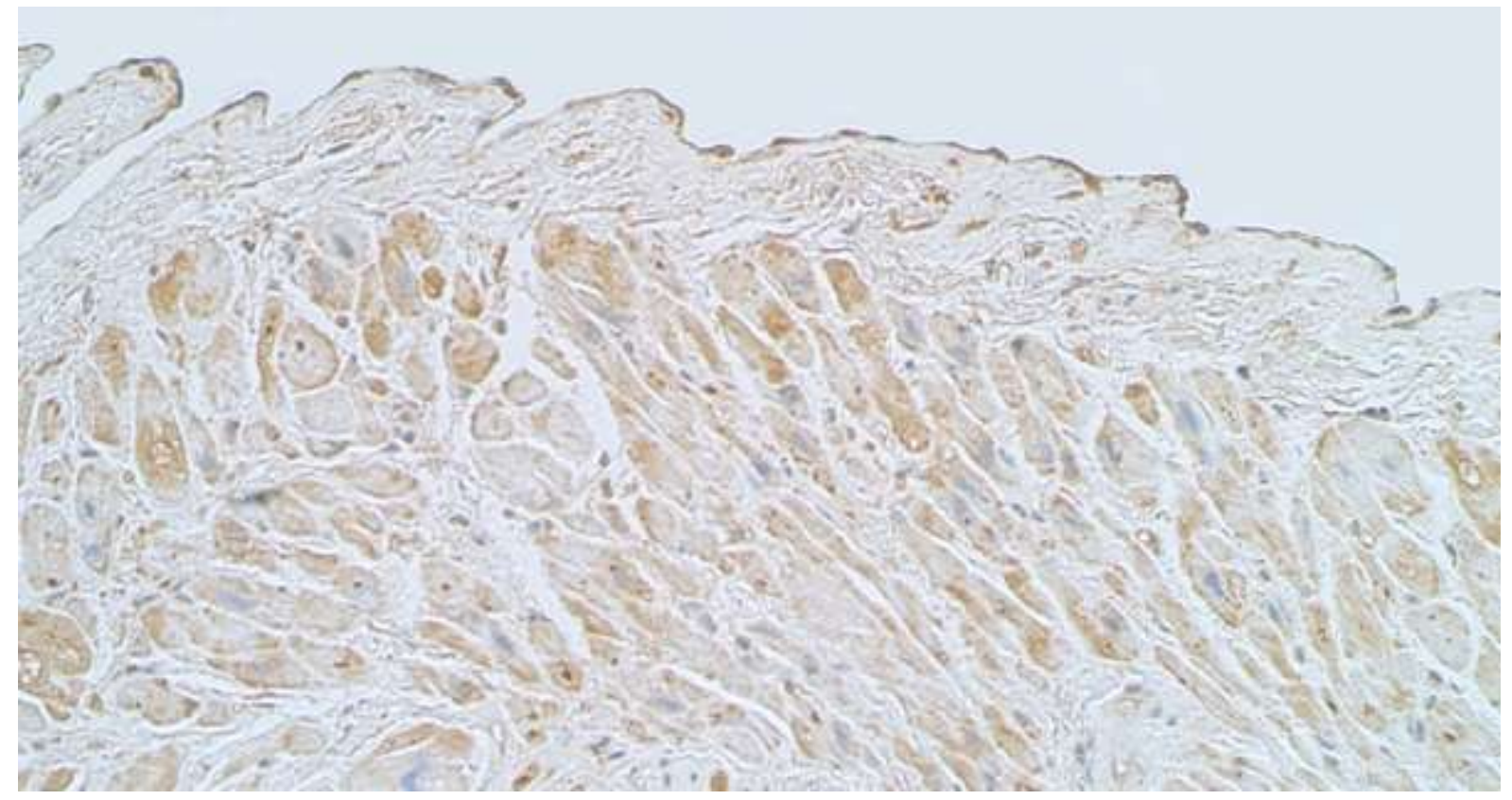

46. attēls. Vidēji daudz Il-10 pozitīvu plakanas formas endokarda endotēlija šūnu labā priekškambara audos 74 gadus vecam pacientam ar AoV stenozi (Il-10 IMH, ×200) 


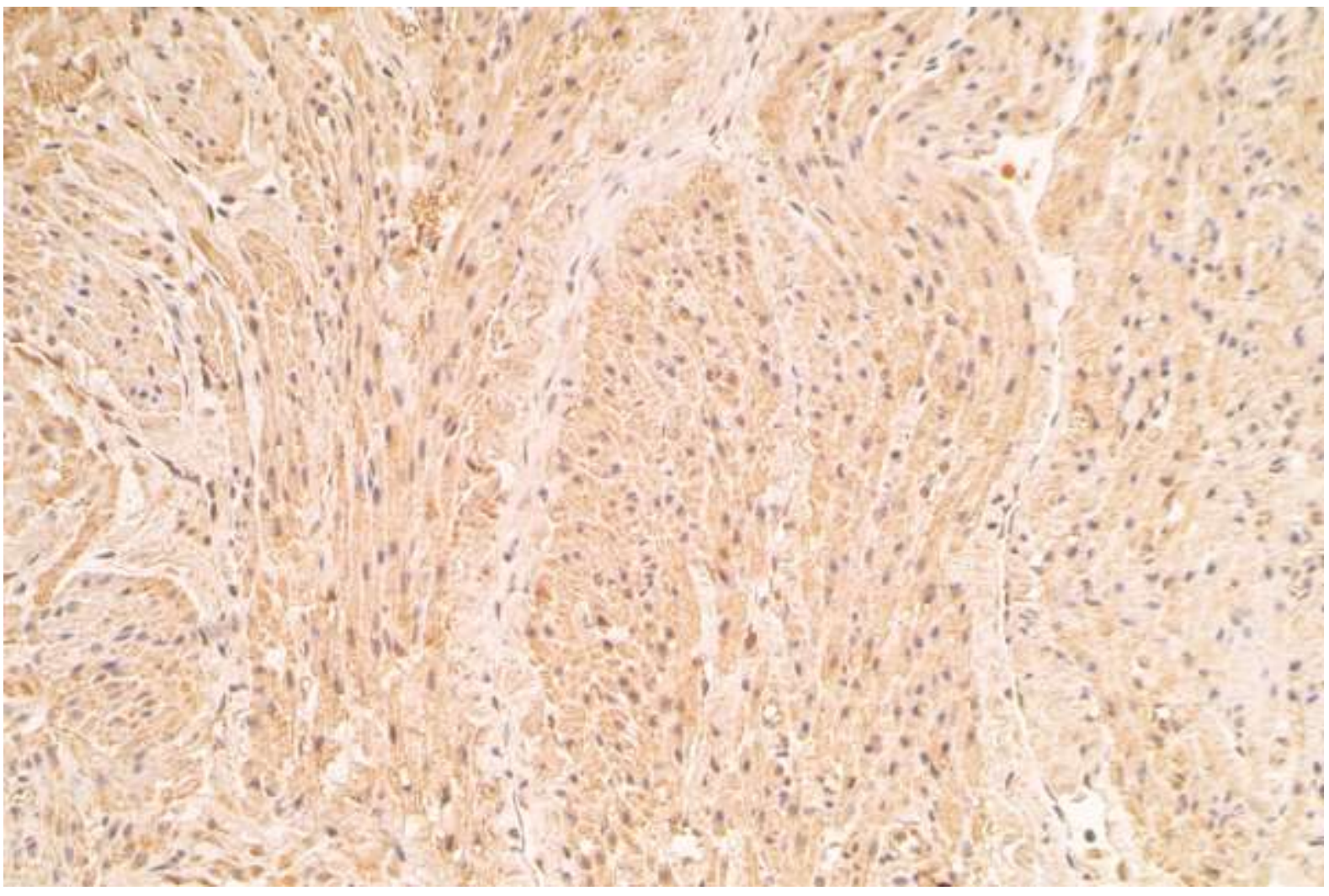

47. attēls. Vidēji daudz līdz daudz Il-10 pozitīvu kardiomiocītu labā priekškambara audos 4 mēnešus vecam pacientam ar kambaru starpsienas defektu (II-10 IMH, ×200)

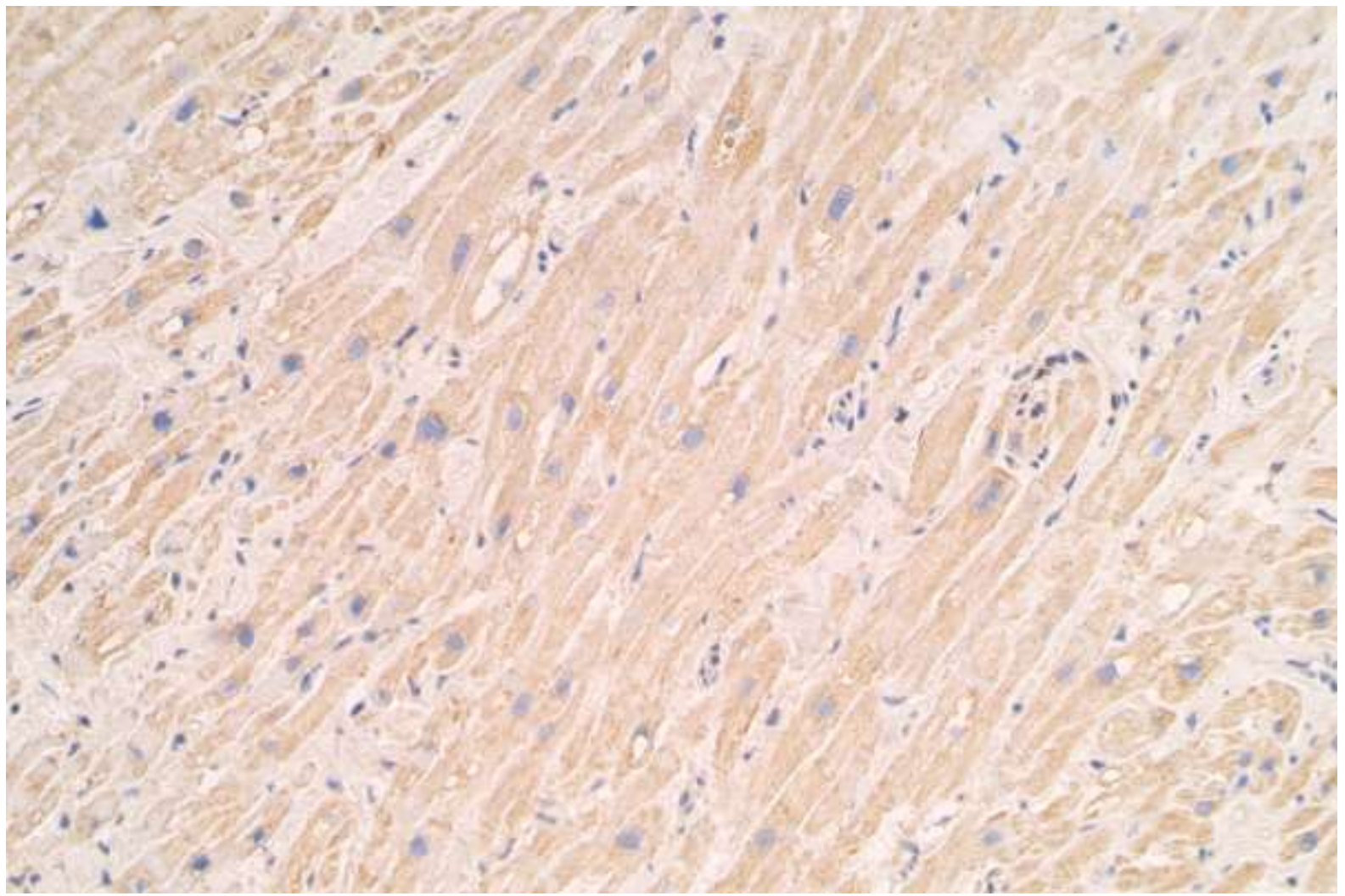

48. attēls. Daudz $\beta D 2$ pozitīvu kardiomiocìtu labā priekškambara audos 66 gadus vecam pacientam ar KSS ( $\beta$ D2 IMH, $\times 200)$ 


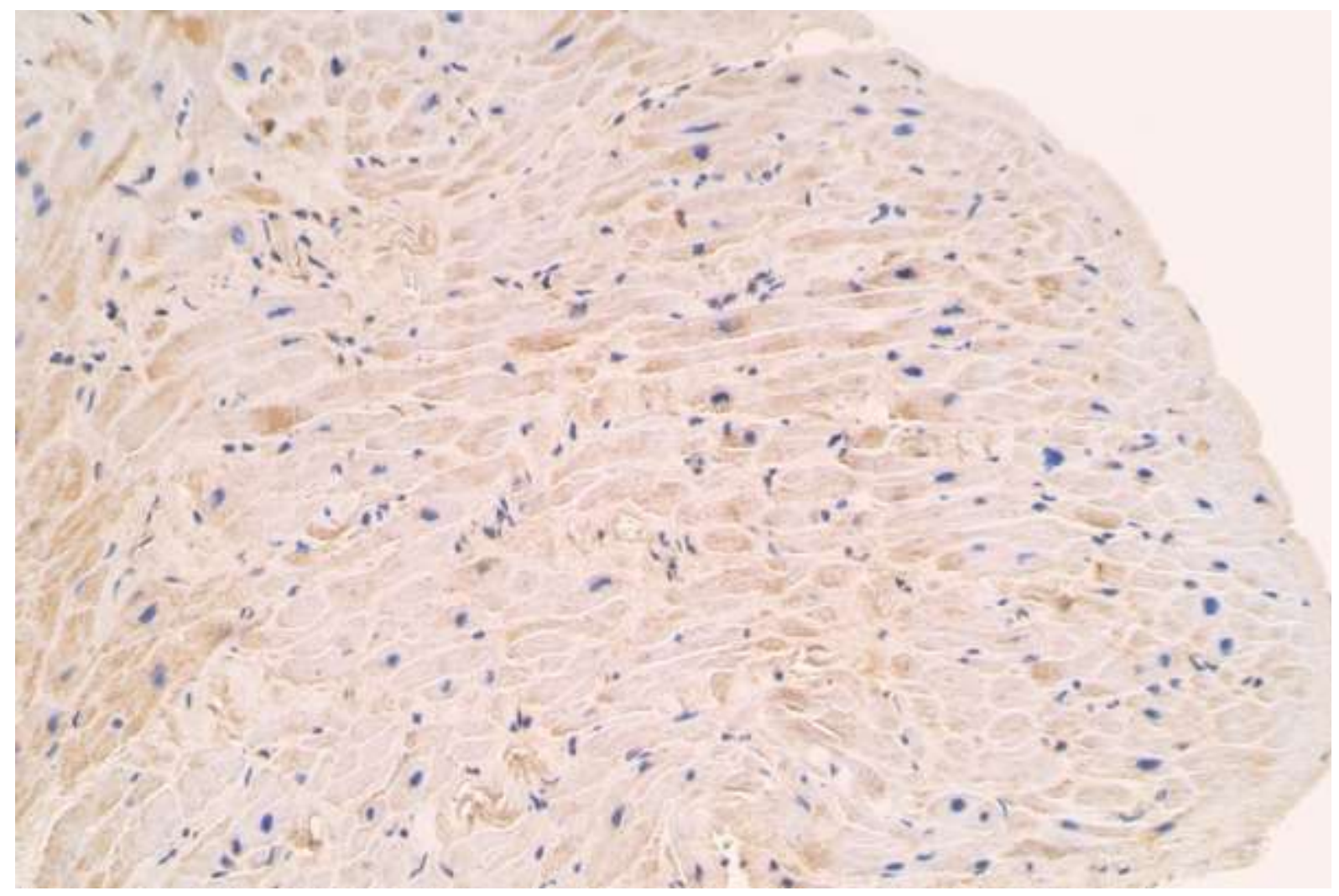

49. attēls. Maz līdz vidēji daudz $\beta D 2$ pozitīvu kardiomiocītu labā priekškambara audos 53 gadus vecam pacientam ar AoV stenozi ( $\beta D 2$ IMH, $\times 200)$

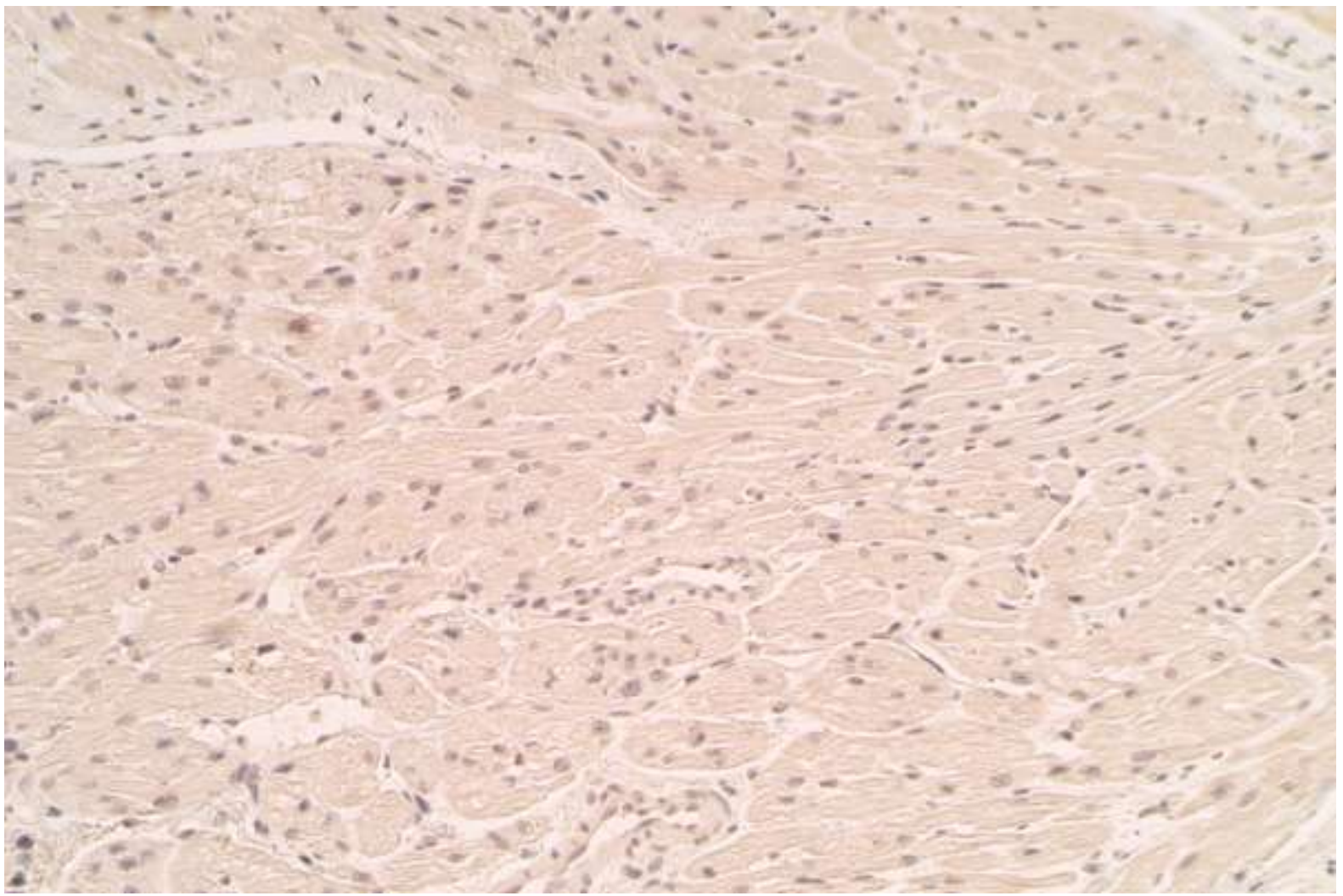

50. attēls. Daudz ßD2 vāji iekrāsotu pozitīvu kardiomiocītu labā priekškambara audos 16 dienas vecam pacientam ar kombinētu iedzimtu sirdskaiti ( $\beta D 2$ IMH, $\times 200)$ 


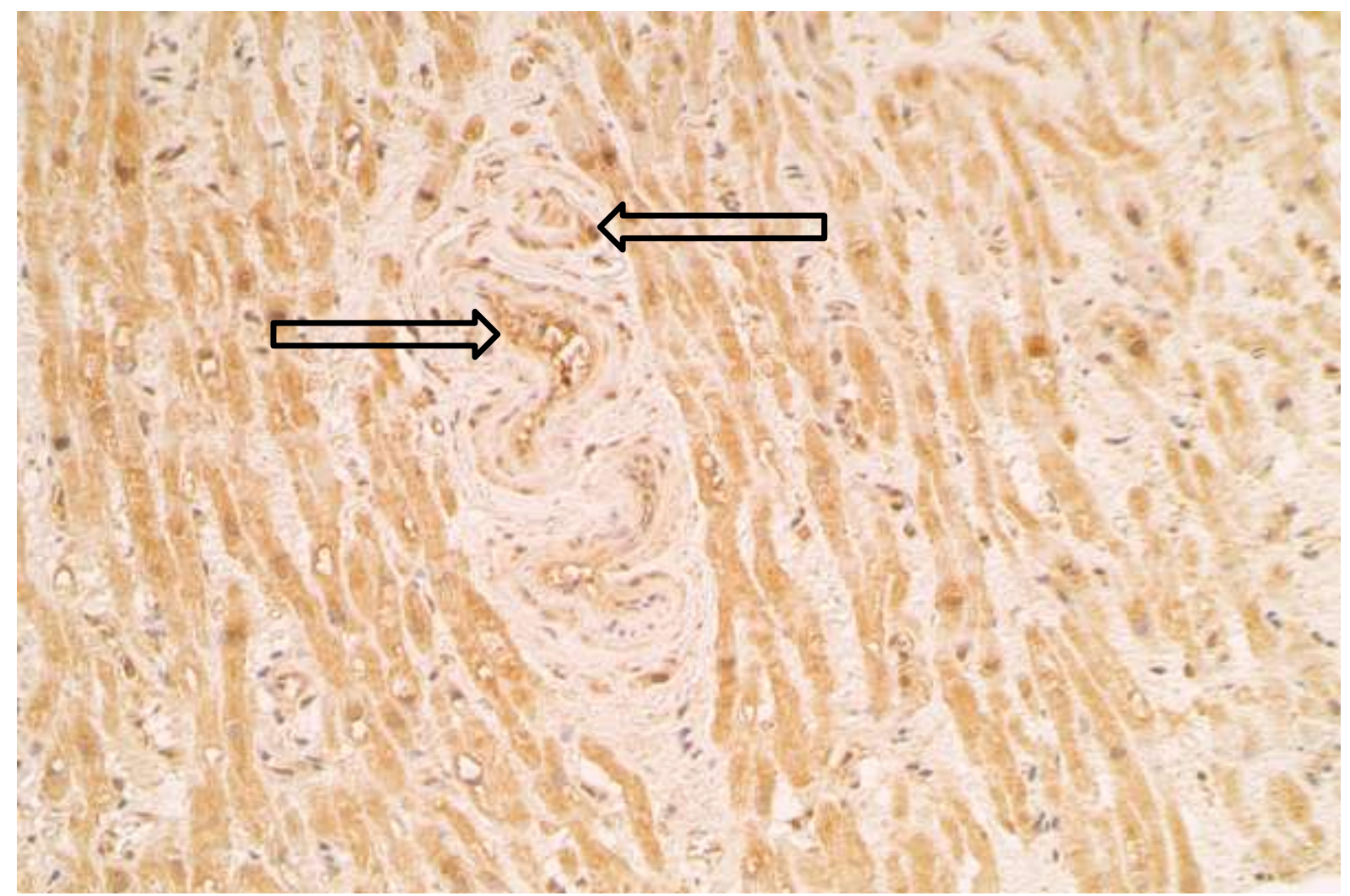

51. attēls. Vidēji daudz $\beta D 2$ pozitīvu endotēlija šūnu labā priekškambara asinsvadā 77 gadus vecam pacientam ar KSS (bultiṇas, $\beta D 2$ IMH, $\times 200$ )

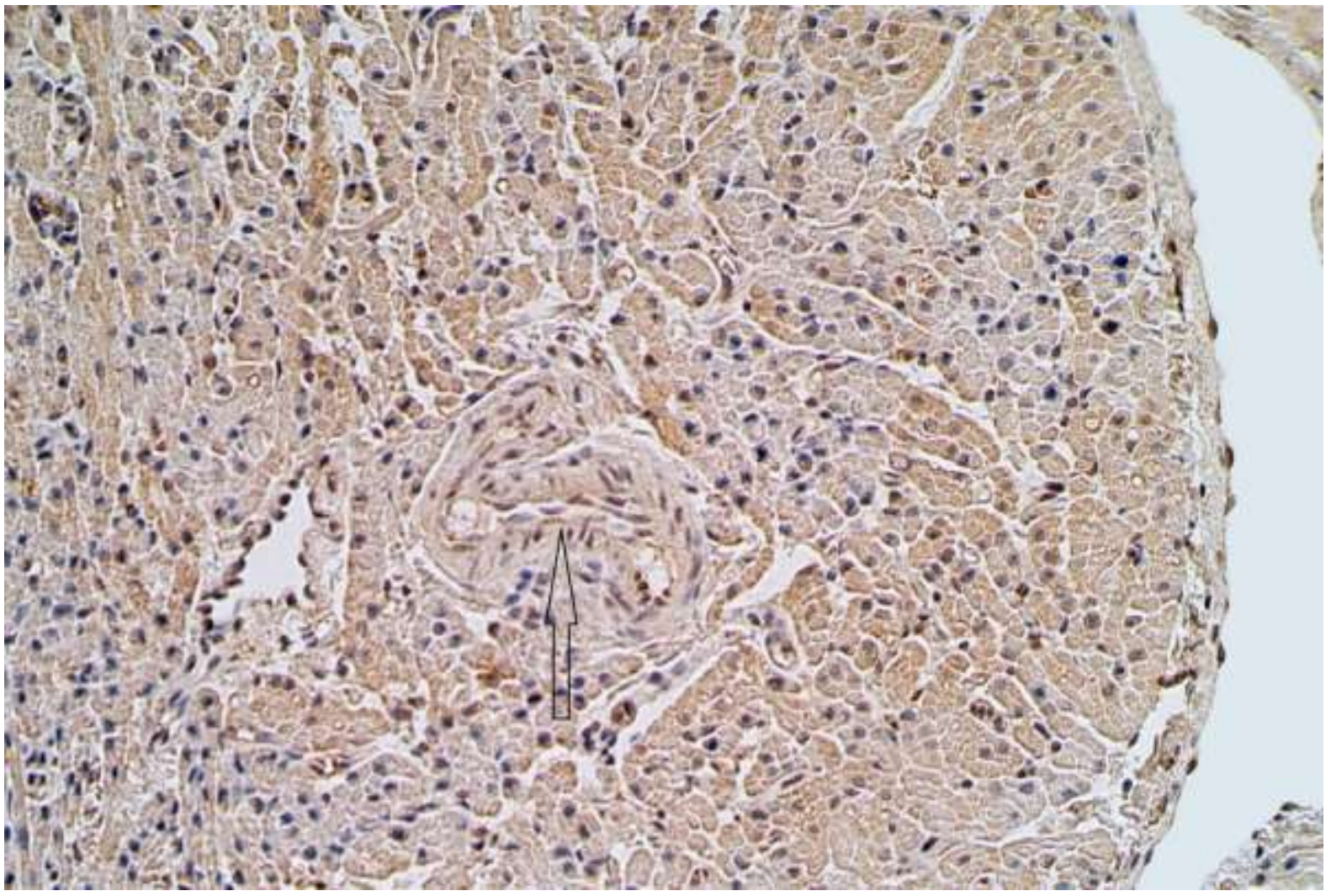

52. attēls. Vidēji daudz ßD2 pozitīvu endotēlija šūnu labā priekškambara asinsvadā 6 mēnešus vecam pacientam ar kambaru starpsienas defektu (bultiņa, $\beta D 2$ IMH, ×200) 


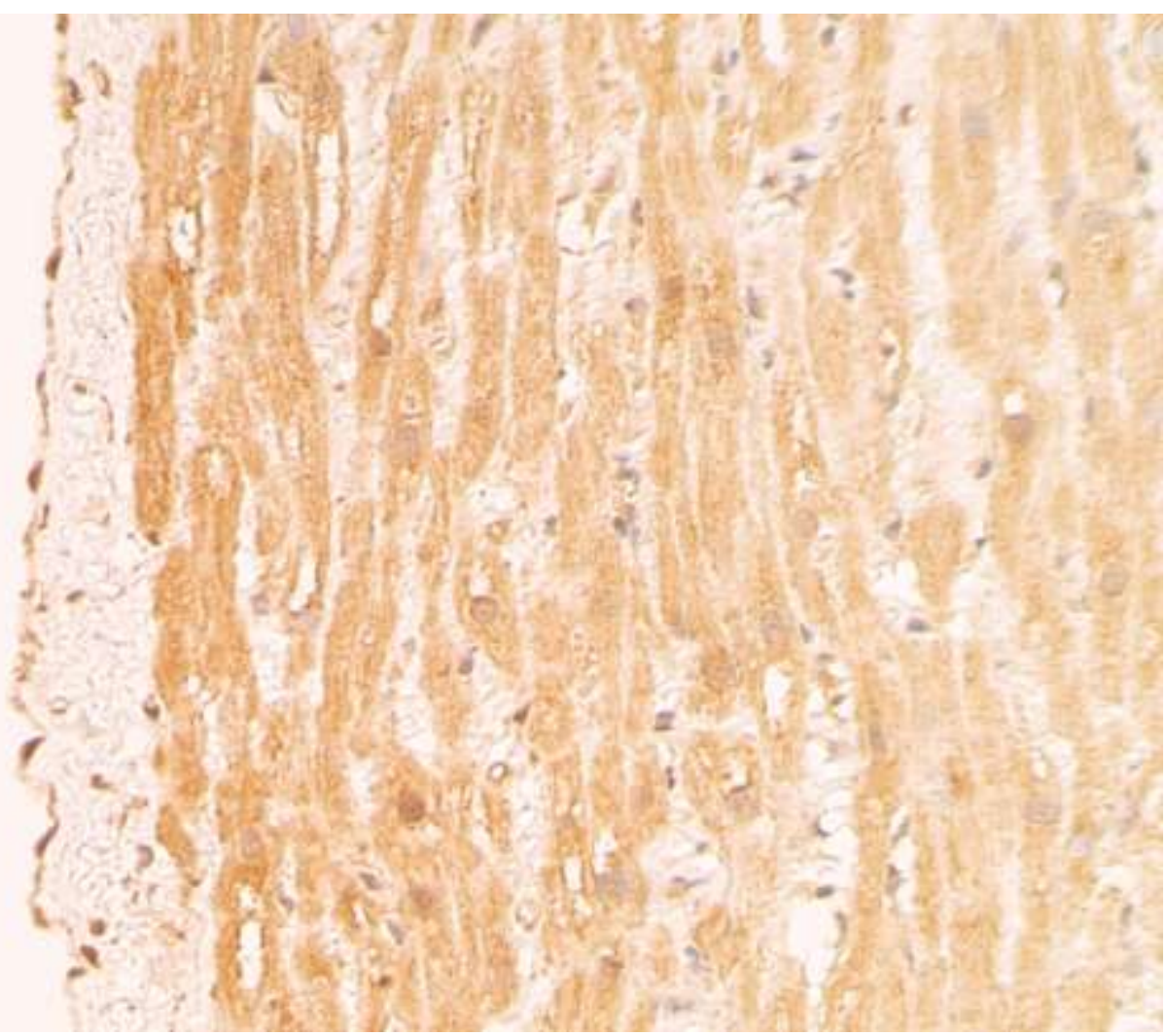

53. attēls. Daudz $\beta D 2$ pozitīvu plakanas formas endotēlija šūnu labā priekškambara endokardā 77 gadus vecam pacientam ar KSS ( $\beta$ D2 IMH, $\times 200)$

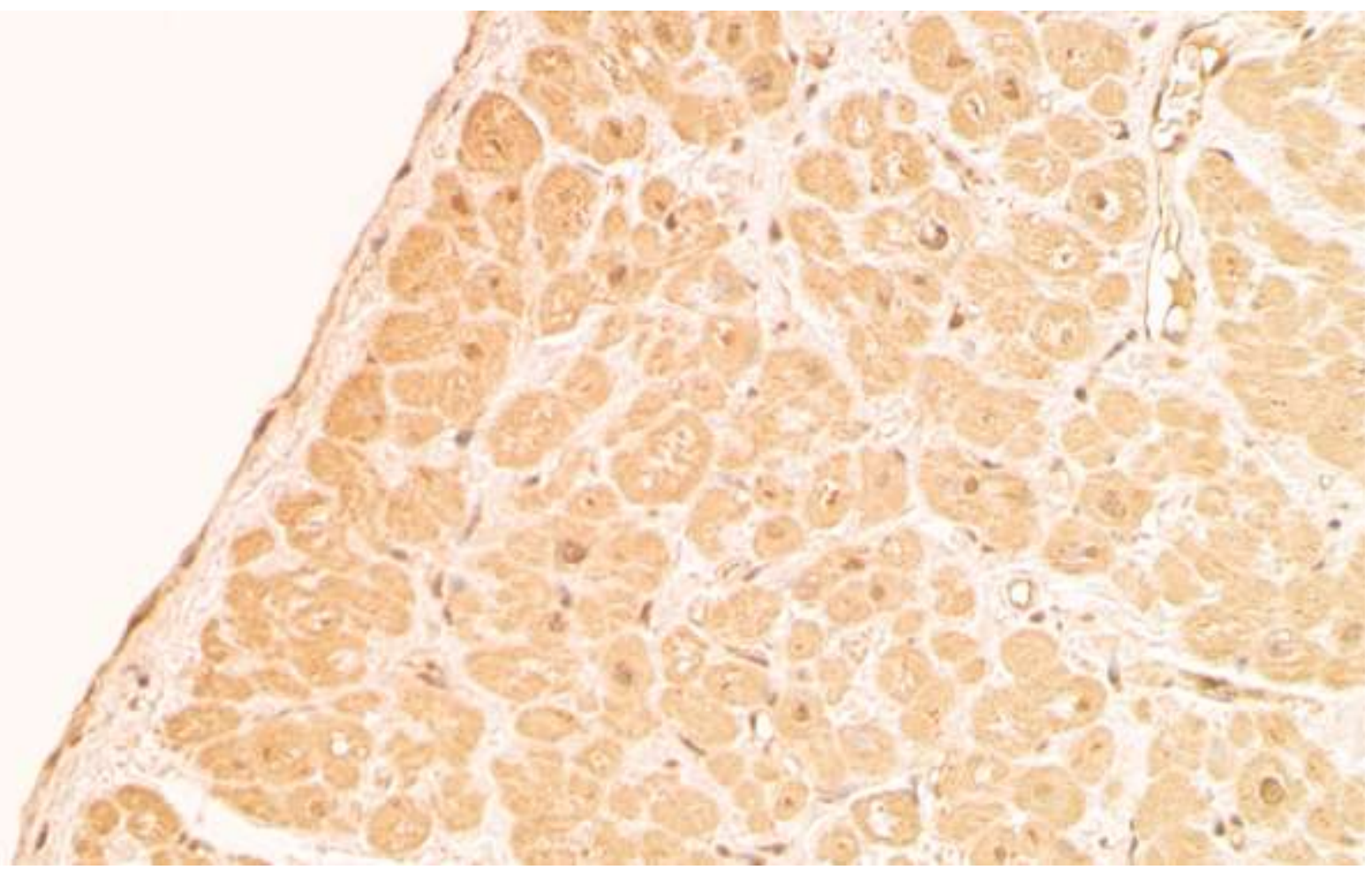

54. attēls. Vidēji daudz $\beta D 2$ pozitīvu plakanas formas endotēlija šūnu labā priekškambara endokardā 83 gadus vecam pacientam ar AoV stenozi ( $\beta D 2$ IMH, ×200) 


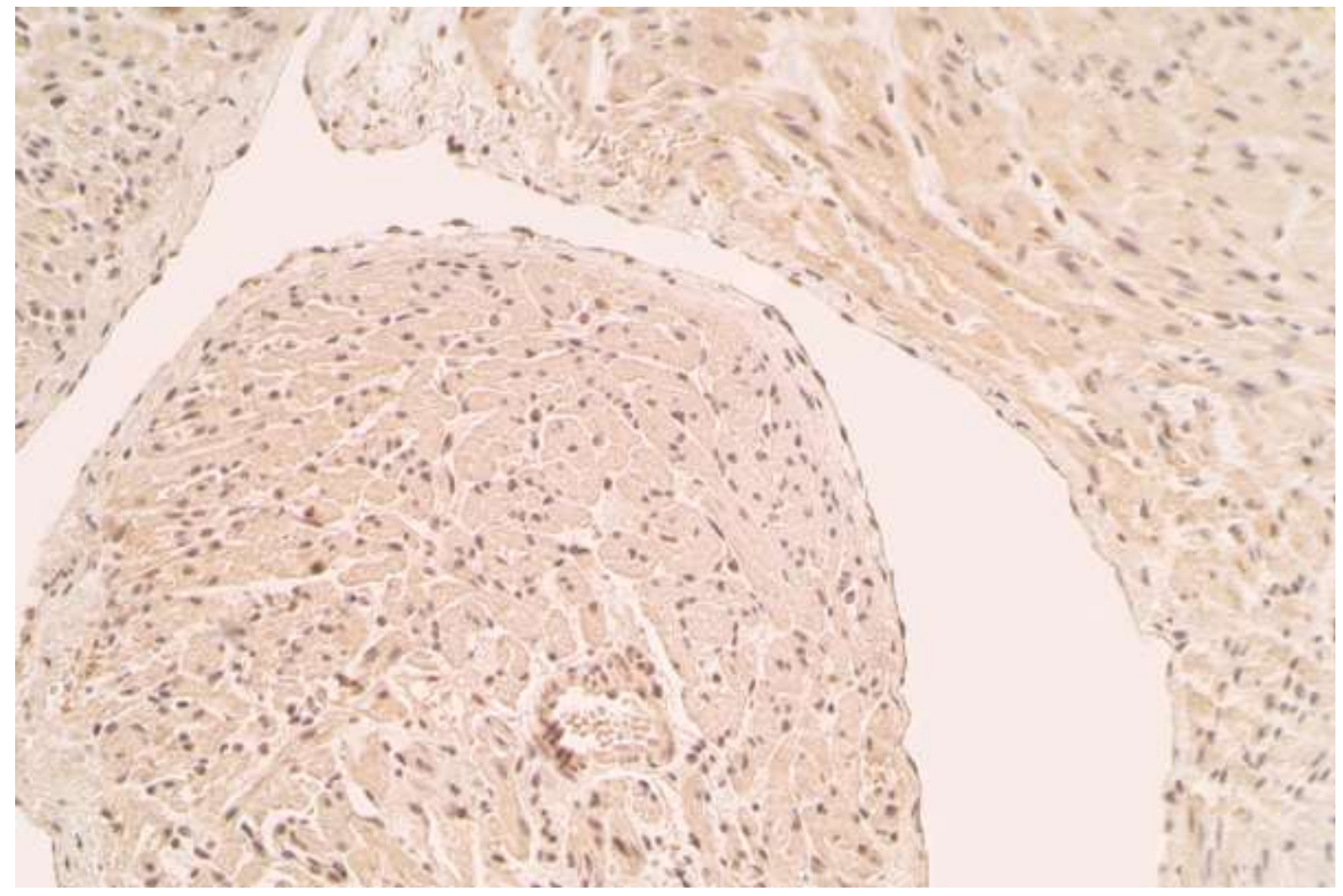

55. attēls. Maz līdz vidēji daudz $\beta$ D2 pozitīvu plakanas formas endotēlija šūnu labā priekškambara endokardā 16 dienas vecam pacientam ar kombinētu iedzimtu sirdskaiti ( $\beta$ D2 IMH, ×200)

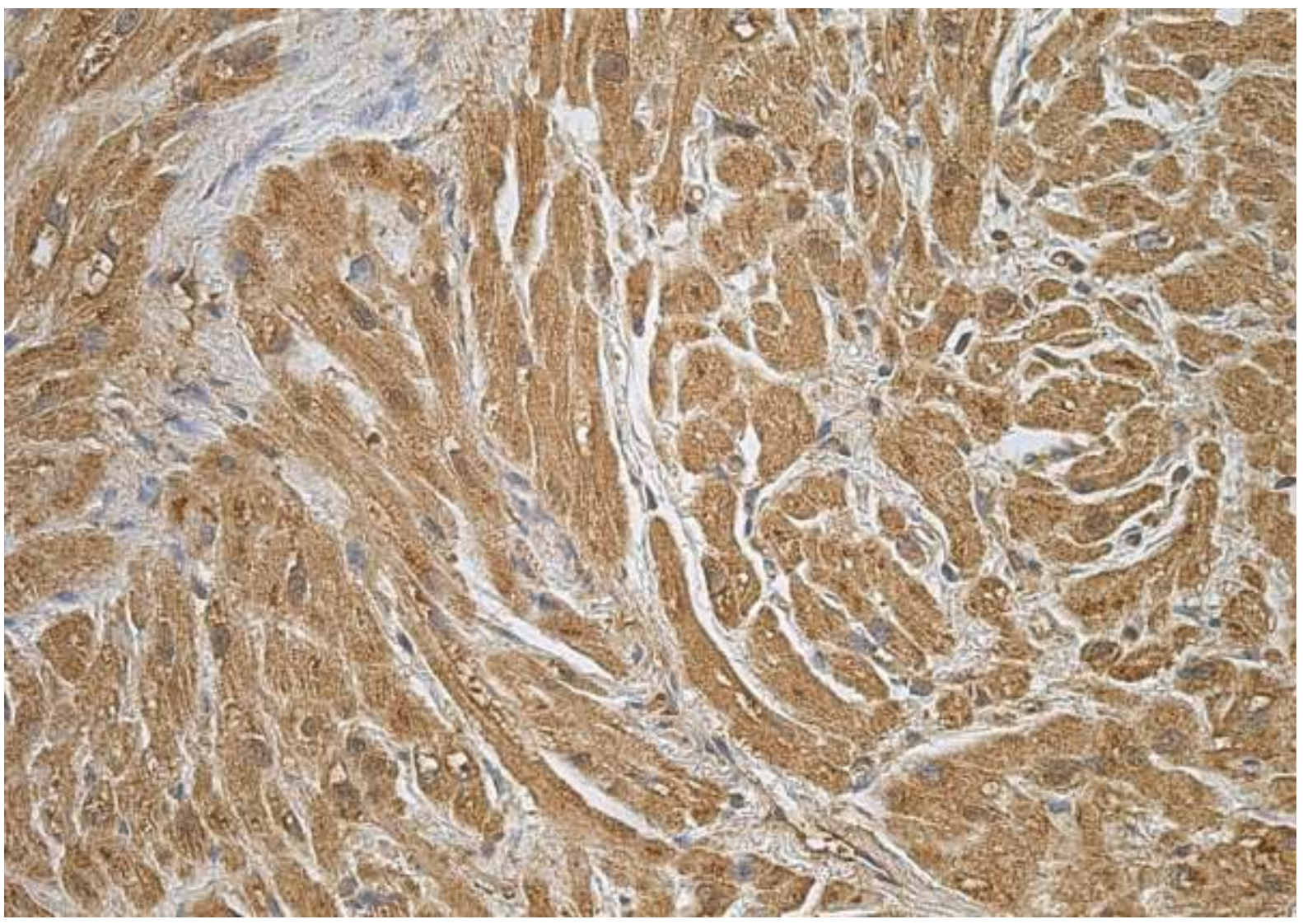

56. attēls. Daudz līdz ḷoti daudz ßD3 pozitīvu kardiomiocītu labā priekškambara audos 70 gadu vecam pacientam ar KSS ( $\beta$ D3 IMH, $\times 250)$ 


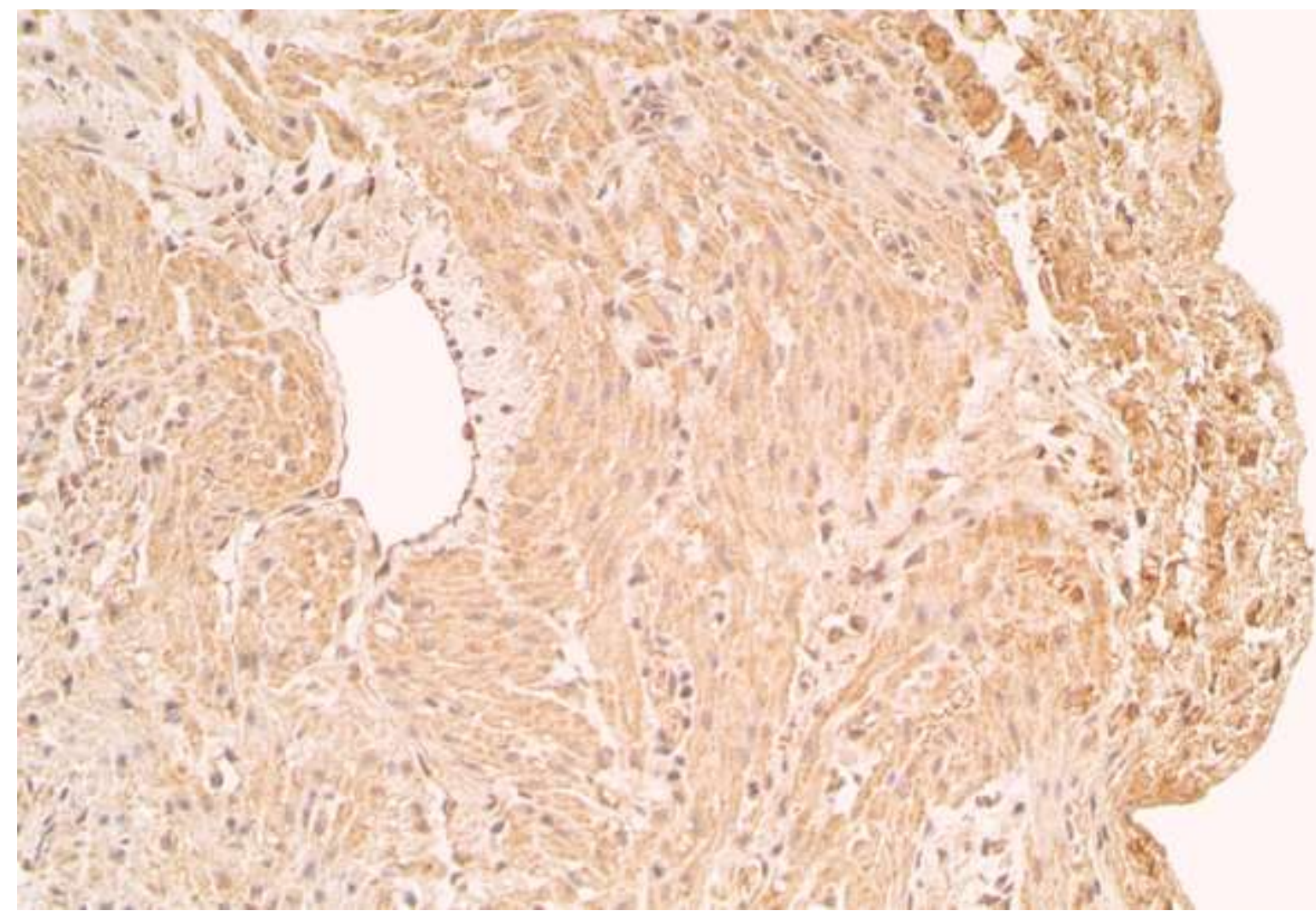

57. attēls. Vidēji daudz līdz daudz $\beta$ D3 pozitīvu kardiomiocītu labā priekškambara audos 4 mēnešus vecam pacientam ar kambaru starpsienas defektu ( $\beta D 3$ IMH, ×200)

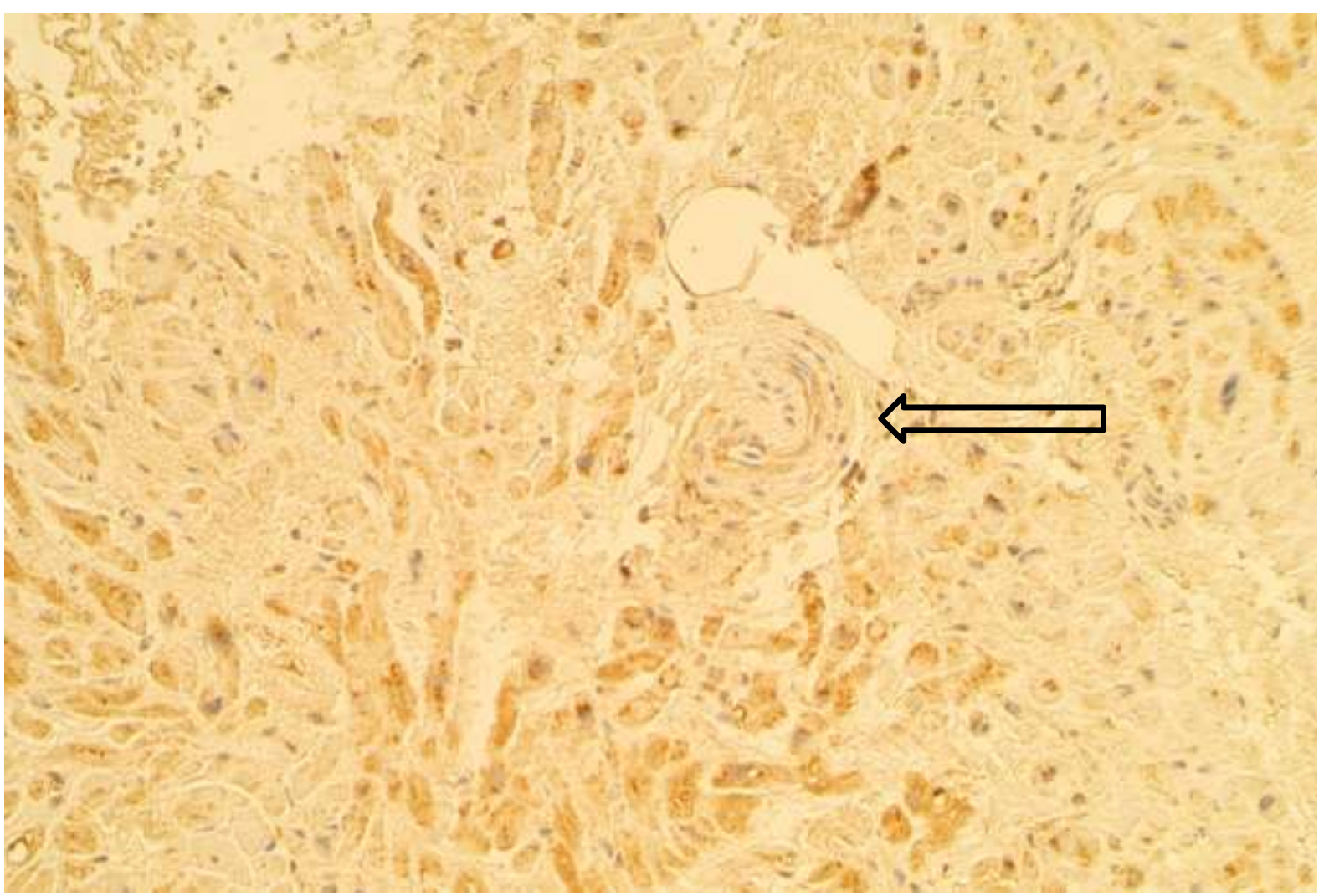

58. attēls. Vidēji daudz $\beta D 3$ pozitīvu endotēlija šūnu labā priekškambara asinsvadā 57 gadus vecam pacientam ar KSS (bultina, $\beta$ D3 IMH, ×200) 


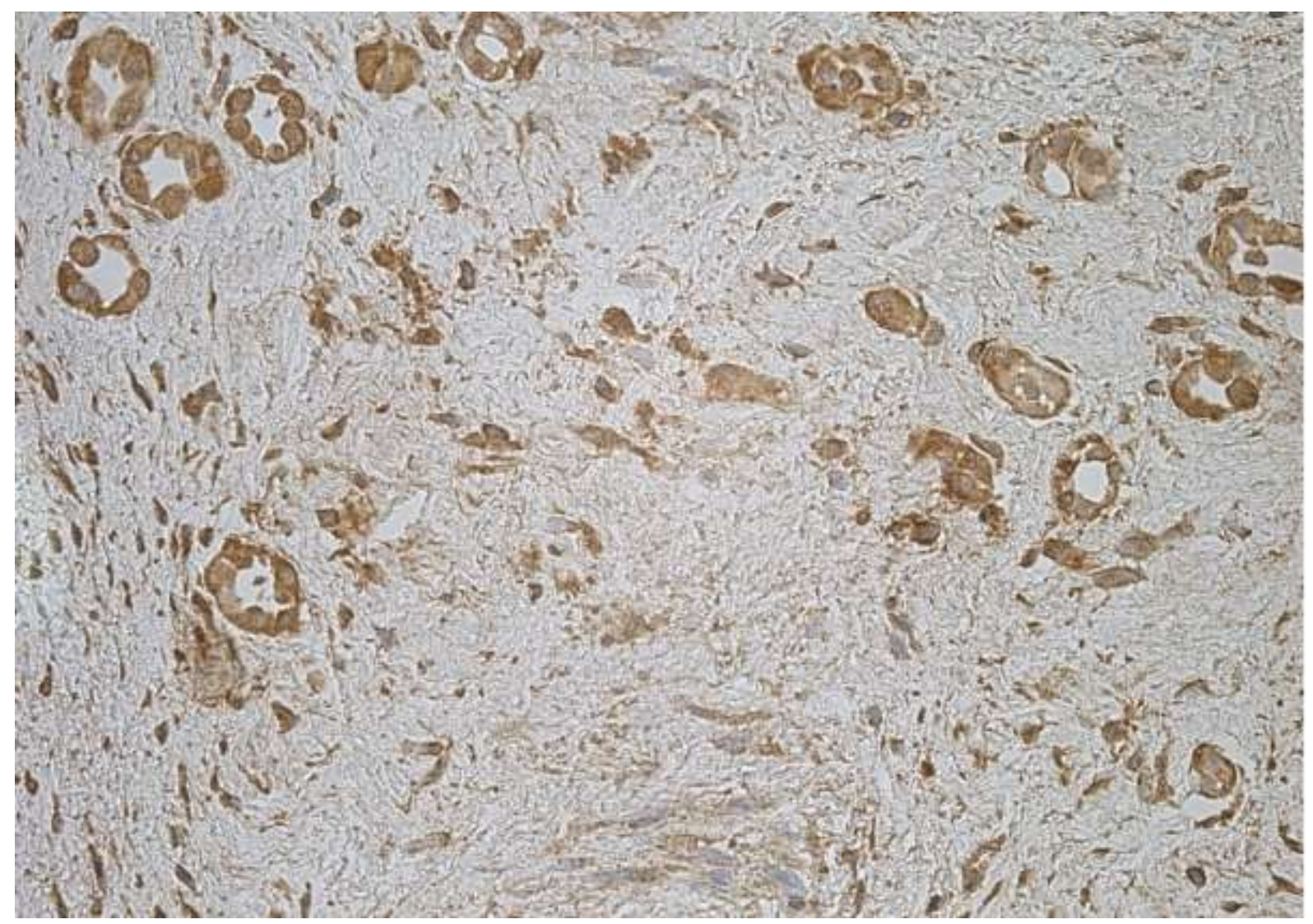

59. attēls. Vidēji daudz līdz daudz $\beta D 3$ pozitīvu endotēlija šūnu labā priekškambara asinsvados 70 gadu vecam pacientam ar AoV stenozi $(\beta D 3$ IMH, $\times 250)$

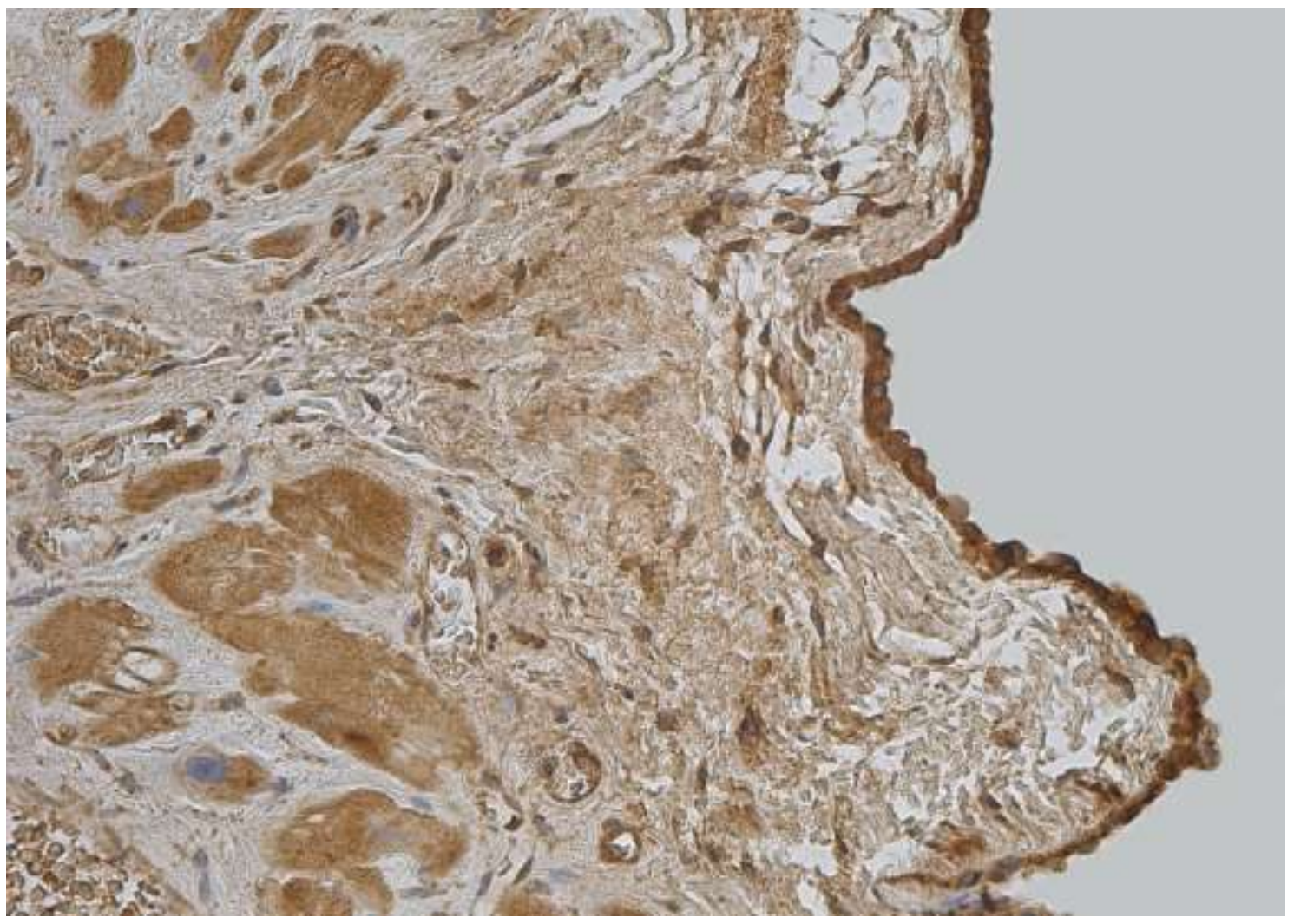

60. attēls. Ļoti daudz $\beta D 3$ pozitīvu epikarda epitēlija šūnu labā priekškambara audos 70 gadu vecam pacientam ar KSS ( $\beta$ D3 IMH, $\times 200)$ 


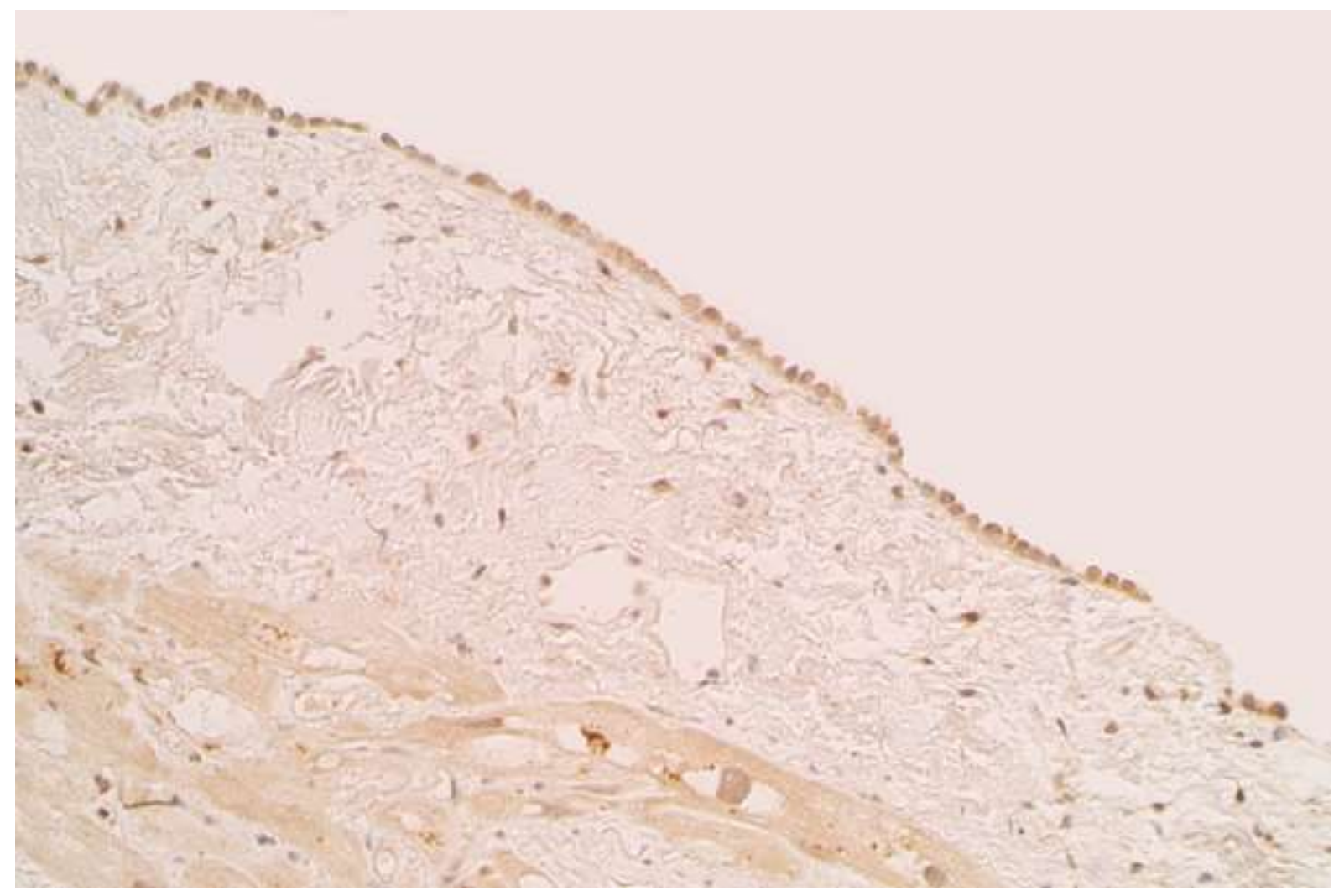

61. attēls. Vidēji daudz $\beta D 3$ pozitīvu endokarda endotēlija šūnu labā priekškambara audos 78 gadus vecam pacientam ar KSS ( $\beta$ D3 IMH, $\times 200)$

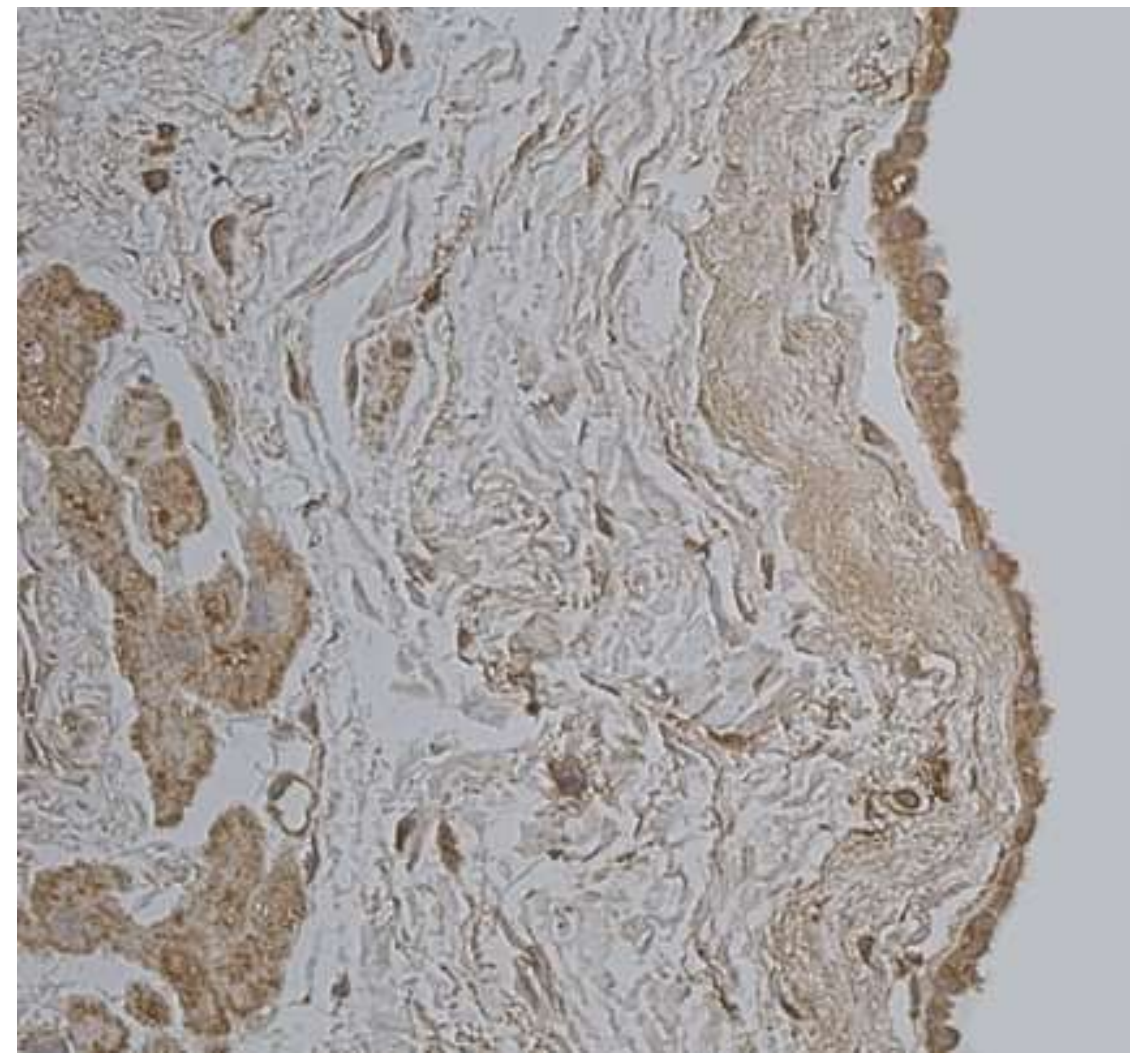

62. attēls. L,oti daudz ßD3 pozitīvu endokarda endotēlija šūnu labā priekškambara audos 73 gadus vecam pacientam ar AoV stenozi $(\beta D 3$ IMH, $\times 200)$ 


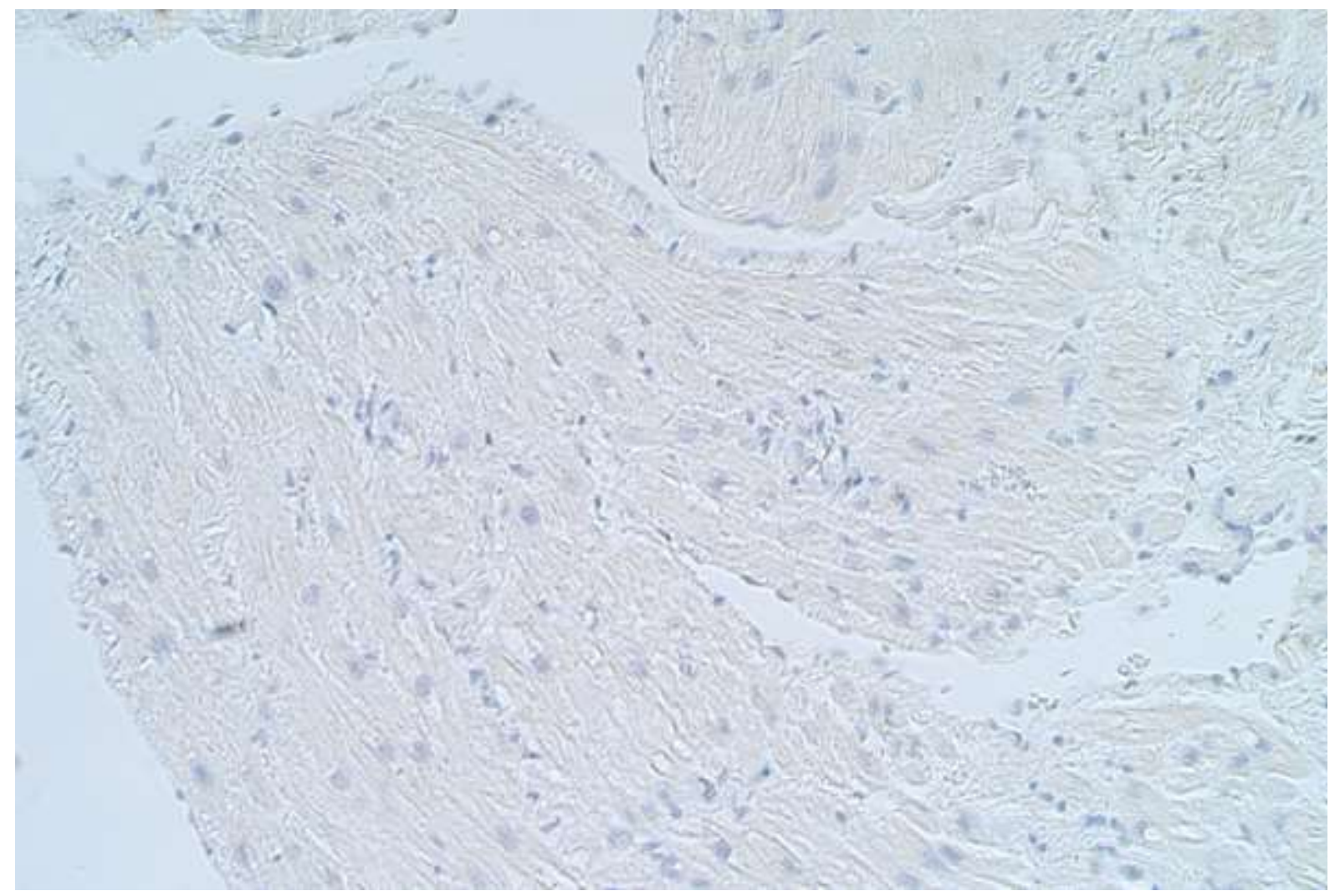

63. attēls. $\beta D 4$ trūkums labā priekškambara audos 80 gadu vecam pacientam ar KSS ( $\beta$ D4 IMH, ×200) 